Florida International University FIU Digital Commons

3-26-2015

\title{
Écfrasis y Lecturas Icono-textuales en las "Leyendas" de Gustavo Adolfo Bécquer
}

Jose Rodriguez

jlrodezco@aol.com

DOI: $10.25148 /$ etd.FI15050205

Follow this and additional works at: https://digitalcommons.fiu.edu/etd

Part of the Modern Languages Commons

\section{Recommended Citation}

Rodriguez, Jose, "Écfrasis y Lecturas Icono-textuales en las "Leyendas" de Gustavo Adolfo Bécquer" (2015). FIU Electronic Theses and Dissertations. 1822.

https://digitalcommons.fiu.edu/etd/1822

This work is brought to you for free and open access by the University Graduate School at FIU Digital Commons. It has been accepted for inclusion in FIU Electronic Theses and Dissertations by an authorized administrator of FIU Digital Commons. For more information, please contact dcc@fiu.edu. 


\title{
FLORIDA INTERNATIONAL UNIVERSITY
}

Miami, Florida

\section{ÉCFRASIS Y LECTURAS ICONO-TEXTUALES EN LAS “LEYENDAS” DE GUSTAVO ADOLFO BÉCQUER}

\author{
A thesis submitted in partial fulfillment of the \\ requirements for the degree of \\ DOCTOR OF PHILOSOPHY \\ in \\ SPANISH \\ by
}

José Luis Rodríguez

2015 
To: Dean Michael R. Heithaus

College of Arts and Sciences

This dissertation, written by José Luis Rodríguez, and entitled Écfrasis y Lecturas Icono-Textuales en las "Leyendas" de Gustavo Adolfo Bécquer, having been approved in respect to style and intelectual content, is referred to you for your judgement.

We have read this dissertation and recommend that it be approved.

Santiago Juan-Navarro

Renee M. Silverman

Ana M. Bidegain

María A. Gómez, Major Professor

Date of Defense: March 26, 2015

The dissertation of José Luis Rodríguez is approved

Dean Michael R. Heithaus

College of Arts and Sciences

Dean Lakshmi N. Reddi

University Graduate School

Florida International University, 2015 
(C) Copyright 2015 by José Luis Rodríguez

All rights reserved 


\title{
DEDICATORIA
}

\begin{abstract}
A la memoria de mis queridos padres,
José Rodríguez y Miranda, y Ana C. Cotilla y Fernández de Castro, sin cuyo amor y ejemplo no me hubiera sido posible realizarme como ser humano.

Como tributo a la bondad de la familia Balboa-Herrera, mis primeros maestros.

A toda mi familia, sin cuyo apoyo, generosidad y comprensión no hubiera podido

llegar hasta aquí.
\end{abstract}




\title{
ABSTRACT OF THE DISSERTATION \\ ÉCFRASIS Y LECTURAS ICONO-TEXTUALES EN LAS “LEYENDAS” \\ DE GUSTAVO ADOLFO BÉCQUER
}

\author{
by
}

José Luis Rodríguez

Florida International University, 2015

Miami, Florida

\section{Professor María A. Gómez, Major Professor}

The relationship between literature and the visual arts is ancient and it has been studied from different conceptual frames. Scholars agree that both have a descriptive function and therefore share the common goal of portraying a fictional or nonfictional reality. Based on this correspondence between two different modes of artistic expression, the Roman poet Horace coined the well-known simile ut pictura poesis --as is painting so is in poetry-- which in turn functions as the theoretical underpinning of ekphrasis, a rhetorical device through which one medium of art tries to describe the essence and form of another medium of art, with the purpose of enhancing the original work described. Spanish post-romantic poet and writer Gustavo Adolfo Bécquer (1836-1870) mastered this rhetorical strategy by expertly weaving all of his artistic interests into his prose.

The purpose of this dissertation is to analyze how Bécquer makes his readers both see and hear through his prose. My semiotic research encompasses the various forms of ekphrasis used by Bécquer in the "Leyendas". It shows how both images and symbols produce in readers sensory experiences that enhance 
their role as active participants in the creation of meaning. Thus, Bécquer's prose is like a painting which not only tells a story, but also reflects reality through the eyes of the reader's imagination.

By using these ekphrastic strategies in his collection of short stories, Bécquer makes words, paintings, and music converge and collide with iconography, visual culture, and intertextuality. These components must be read, seen, heard, and understood to be more than just complementary to the text, but rather crucial elements, equal in importance to verbal expression. This analysis shows how Bécquer's "Leyendas" not only tackle notions such as fantasy, figuration, and imagination, but also the importance of the reader's gaze. Bécquer integrates processes such as imaginative action, iconization and visualization, into a semantic web whereby the reader creates his own particular hermeneutic image. 


\section{AGRADECIMIENTOS}

Quisiera expresar mi profundo agradecimiento a la Dra. María A. Gómez, mi directora de tesis, por su apoyo incondicional, así como por su valiosa orientación, paciencia y dedicación a lo largo de estos años. Su comprensión y solidaridad en una etapa difícil de mi vida fueron decisivas.

Asimismo, deseo expresar mi agradecimiento a los miembros del comité, la Dra. Ana M. Bidegain, el Dr. Santiago Juan-Navarro y la Dra. Renee M. Silverman, por su paciencia y consejos en la consecución de este trabajo.

A Luis R. Casas, Sr. y Luis R. Casas, Jr. por sus muestras de apoyo, estímulo y útiles consejos en la revisión de este trabajo, así como en el valioso asesoramiento cibernético. La cooperación de ambos ha sido decisiva en la culminación de esta labor.

A Jacqueline Dipp por su siempre afectuosa disposición a prestar ayuda en todo momento, y por su apreciada orientación desde que entró a formar parte del Departamento de Lenguas Modernas.

Al Dr. Leonel A. de la Cuesta por su inestimable ayuda, entusiasmo y estímulo a lo largo de estos años.

A mis maestros y profesores que, a lo largo de los años, fueron cimentando las bases de mi formación. A todos ellos, mi eterno agradecimiento. 


\section{ÍNDICE}

CAPÍTULO

PÁGINA

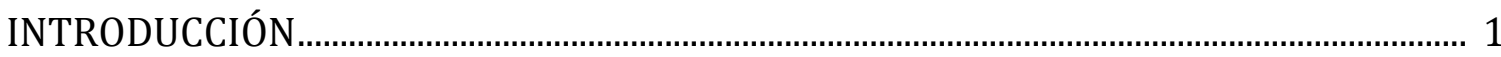

NOTAS A LA INTRODUCCIÓN ................................................................................................. 13

I. ANTECEDENTES ARTÍSTICOS EN LA CONSTRUCCIÓN DE LA ECFRASIS

BECQUERIANA ……………………….............................................................. 14

I.1. El concepto de écfrasis: origen y tipologías ............................................................... 29

I.2. La écfrasis becqueriana ............................................................................................. 43

I.3. Mímesis, ilusión, impresión y/e (re)interpretación ..................................................... 47

I.4. La pintura como ejercicio preliminar de las "Leyendas"............................................. 57

NOTAS AL CAPÍTULO I ……………………………………..................................................... 71

II. CARACTERÍSTICAS Y ANTECEDENTES DEL GÉNERO ………………………….......... 72

II.1. Los temas de las "Leyendas" ......................................................................................... 81

II.2. Los límites de la expresión verbal en la teoría poética de Bécquer......................... 85

II.3. Las intermediales visuales como técnicas narrativas............................................... 90

II.4. La Historia de los templos de España como antecedente de las "Leyendas"........96

NOTAS AL CAPÍTULO II....................................................................................................... 105

III. EL PAISAJE EXÓTICO EN LAS LEYENDAS DEL CICLO NARRATIVO HINDÚ ..........106

III.1. Fuentes del ciclo narrativo hindú............................................................................ 112

III. 2. Análisis de las leyendas del ciclo narrativo hindú …………………………......... 122

NOTAS AL CAPÍTULO III ...................................................................................................... 148

IV. LA EDAD MEDIA EN LA COMPOSICIÓN ESCENOGRÁFICA Y EL PAISAJE DE LAS "LEYENDAS" ................................................................................................ 150

IV.1. Las edificaciones, las ruinas y los paisajes en la pluralidad de los escenarios medievales de las "Leyendas"............................................................ 159

NOTAS AL CAPÍTULO IV ...................................................................................................... 212

V. EL CUADRO PICTÓRICO COSTUMBRISTA EN “MAESE PÉREZ, EL ORGANISTA" Y EL ECLECTICISMO EN “EL GNOMO", "LA CUEVA DE LA MORA", “EL BESO” Y “LA ROSA DE LA PASIÓN”................ 215

V.1. La pintura costumbrista en las "Leyendas" ............................................................ 222

V.2. El eclecticismo en algunas de las "Leyendas" ............................................................ 233

NOTAS AL CAPÍTULO V ........................................................................................................... 260

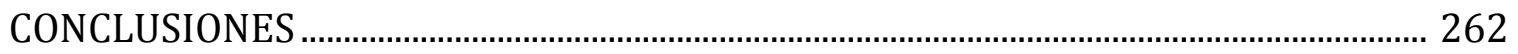

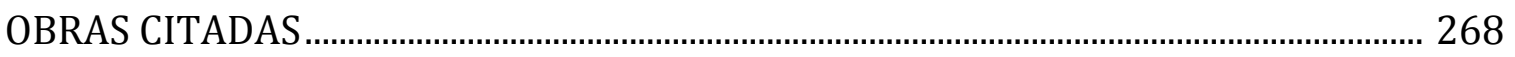

VITA 


\section{INTRODUCCIÓN}

Las relaciones analógicas entre la pintura y la literatura tienen una larga y compleja tradición histórica que se inicia en la antigüedad clásica. Las primeras manifestaciones aparecen en la $\underline{\text { República }}^{1}$ de Platón y en la $\underline{\text { Poética }}^{2}$ de Aristóteles. Sin embargo, las más conocidas se deben a dos poetas clásicos: Simónides de $\operatorname{Ceos}^{3}$ y Quinto Horacio Flaco ${ }^{4}$. En su obra, De Gloria Atheniensium, Plutarco ${ }^{5}$ atribuyó al primero la afirmación de que "la poesía es pintura verbal" y "la pintura es poesía muda"6, lo que se ha considerado, desde antiguo, como el origen de la concepción aristotélica de la literatura o del arte como disciplinas que tratan de representaciones o imitaciones; esto es, de la mímesis. Así, siguiendo esa línea de pensamiento, Quinto Horacio refiere en su Epístola a los pisones, que "[l]a poesía es como la pintura" (179), lo que sintetiza en su conocido axioma: Ut pictura poesis, una fórmula ya canónica dentro de los estudios sobre la écfrasis, que nos permite afirmar, por otra parte, que ambas manifestaciones revelan visiones comunes entre de Ceos y Horacio sobre las relaciones analógicas de la pintura y la literatura, al margen de la similitud en las palabras, que uno y otro utilizan.

Las aproximaciones son, sin embargo, distintas: De Ceos aprovecha la capacidad sugerente de la metáfora para sintetizar su declaración, mientras que Horacio se vale de un símil, lo que contribuye a hermanar la pintura y la poesía en su ya clásica analogía, motivo por el que pasarían a conocerse, desde entonces, como "artes hermanas"7. Con el transcurso del tiempo, el símil horaciano llegó a constituirse en uno de los principios fundamentales de la estética, y en el centro de un intenso y extendido debate, que ha generado, hasta nuestros días, un sinnúmero 
de discusiones y planteamientos de un buen número de teóricos de la literatura, por cuanto ofrece infinitas oportunidades para la (re)lectura de estas correspondencias entre la literatura --en su origen, la poesía-- y las artes, en general. En ese sentido, tanto la metáfora de Simónides de Ceos como el símil de Horacio se refieren a declaraciones que proponen la comparación y analogía entre palabra e imagen; y plantean, por otra parte, que el debate sobre las relaciones inter-artísticas está unido a la reflexión acerca del problema de la referencialidad y de la relación entre realidad y representación, lo que constituye un vasto campo de investigación.

Mucho tiempo después, los renacentistas, en su intento de hallar modelos clásicos, vuelven a tomar esta analogía y la proyectan como normativa en una serie de propuestas. De un análisis sobre las aptitudes que tiene cada arte de imitar la naturaleza, se pasa a preparar una teoría de la imitación para defender la semejanza entre las artes, desde la concepción aristotélica de "mímesis", cuyo principio de imitación a la naturaleza debe interpretarse como el fin esencial del arte. Durante el siglo XVIII y principios del XIX, pero sobre todo durante el Romanticismo, la tradición artística europea retomó las analogías de Simónides de Ceos y de Quinto Horacio como punto de partida para explorar nuevas lecturas e interpretaciones críticas a partir de estas correspondencias artísticas entre pintura y literatura.

Las Leyendas de Gustavo Adolfo Bécquer se inscriben, precisamente, en ese diálogo artístico entre pintura y literatura. En ellas, de acuerdo con Pascual Izquierdo, "van sucediéndose las escenas, mostradas de forma secuencial como fotogramas de un discurso cinematográfico: abundan los fotogramas llenos de ritmo y dinamismo, de vistosidad y colorido, intensidad y brillantez" (34). Parece lícito 
afirmar, quizás mucho más acertadamente, que las Leyendas nos presentan una secuencia de cuadros o pinturas, en tanto que objetos visuales que han sido evocados mediante el texto, esto es, la palabra, a través de los recursos ecfrásticos de que se vale Bécquer en estos relatos. Por otro lado, nos resultaría casi imposible separar lo visual del mundo narrativo de Bécquer. Para él, no hay deslindes infranqueables entre pintura y literatura que interrumpan ese diálogo artístico, y creemos que tampoco debería haberlo. Además, René Wellek reconoce que "no hay ningún problema teórico específico en el hecho de que las artes están en constante interrelación, como lo están todas las actividades humanas" (29-30), y se suma a los esfuerzos de la literatura por convertirse en pintura verbal, intentando lograr los efectos de la pintura. Así, declara:

[D]ifícilmente cabe negar el éxito de la fórmula horaciana de 'ut pictura poesis'... [H]a habido épocas y ha habido poetas que han obligado al lector a 'ver'... La literatura moderna desde Chateaubriand a Proust nos ha dado muchas descripciones que, al menos, hacen pensar en los efectos de la pintura y que nos mueven a representarnos escenas evocadas no pocas veces por asociación con cuadros. (152)

De acuerdo con este argumento, en las Leyendas de Bécquer la visualización contribuye a acercarnos al ser de las cosas, como si se tratara de una pintura o de un fotograma, si aceptamos el término de Pascual Izquierdo. La narración cobra, entonces, la "vivacidad" de lo existente. La analogía con la pintura es vital para Bécquer, pues la "vivacidad" enunciada estaba para él en la posibilidad de observación del espectador, en lo que el sentido de la vista podía captar y recrear. 
Para ello, se apropia del concepto clásico que hacía efectiva la poesía --en nuestro análisis, la narrativa-- cuando alcanzaba la verosimilitud o se parecía a la naturaleza, o a una representación pictórica de la naturaleza.

En cuanto a los estudios críticos sobre la obra becqueriana, nos enfrentamos a una paradoja: las relaciones de Gustavo Adolfo Bécquer con el mundo del arte, y muy especialmente con las artes plásticas y la música, constituyen una parte fundamental y muy conocida de su biografía, pero ni su obra plástica ni su particular visión artística en su obra narrativa han sido debidamente estudiadas, a pesar de algunos trabajos aislados, como el estudio de Franz Schneider, en alemán, y sólo traducido al español en 2005, Gustavo Adolfo Becquer: Leben und Shaffen unter besonderer Botunung des chronologischen Elementes (1914); el de Arturo Berenguer Carisomo, La prosa de Bécquer (1947); el de Edmund L. King, Gustavo Adolfo Bécquer, from painter to poet (1953), o el más reciente trabajo de Jesús Rubio Jiménez, Pintura y literatura en Gustavo Adolfo Bécquer (2006), que a pesar del sugerente título está mucho más centrado en sus aspectos biográficos y en los álbumes artísticos --analizados desde una perspectiva tradicional-- que en la influencia del arte en su literatura. Sin embargo, Rubio Jiménez incluye muchos de los trabajos artísticos de Bécquer, fundamentalmente dibujos, así como un buen número de reproducciones de estas obras; aunque como el mismo acota, lo reproducido es de "carácter fragmentario" (289). Cabe añadir, por otra parte, que muchos de los dibujos o pinturas de Bécquer se hallan dispersos en colecciones privadas, dentro y fuera de España, muchas veces hasta ignorados por sus poseedores, o desaparecidos durante las revoluciones y los conflictos bélicos. Igual 
suerte corrieron la mayoría de las obras de su padre, primo y hermano. La tarea de rescatar esa obra dispersa, por demás poco estudiada, recabará un arduo trabajo de investigación y localización.

La mayor parte de los otros trabajos sobre Bécquer se centra en estudios biográficos, como los ya clásicos de Rica Brown, Rubén Benítez, Pedro José Díaz, Rafael Montesinos, Heliodoro Carpintero y Robert Pageard, entre otros, o en artículos sobre determinados aspectos de su obra, sobre la poesía becqueriana, más que todo. Existen pocos trabajos sobre su prosa, y menos aún sobre las Leyendas. Salvo el trabajo de King, ya mencionado, no existe ningún estudio posterior que trate en profundidad la influencia de las artes plásticas en su obra literaria, aunque mucho se ha escrito sobre la plasticidad de su estilo, que es, precisamente, el objeto de este estudio.

Debo subrayar, por otra parte, que los antecedentes artísticos de Bécquer son clave para comprender en toda su extensión su quehacer literario, en particular sus Leyendas; por ello, he intentado abundar en esa etapa de su formación artística, como punto de partida de las relaciones entre imágenes y palabras en estos textos. En tal sentido, pondré de relieve el problema de la écfrasis como recurso literario fundamental utilizado por Bécquer para evocar e invocar la realidad en estos relatos legendarios. Así, será válido afirmar que tal analogía se produce por su sensibilidad y formación artísticas, las que se ven estimuladas y enriquecidas por un ambiente familiar donde predominaba la actividad pictórica, así como por el círculo de pintores sevillanos y extranjeros, sobre todo ingleses, que formaron parte de ese entorno. 
La lectura que propongo para las leyendas becquerianas es, precisamente, una lectura icono-textual, en tanto y en cuanto el concepto de icono-texto se interprete como la fusión creadora de ambos objetos: el visual y el textual. Por consiguiente, la imagen plástica es sólo un referente artístico, real o ficticio en cuanto a sus fuentes, pero que no acompaña materialmente al texto, como sí ocurre en las historias, las novelas y los cuentos ilustrados, así como en los emblemas y las viñetas o tiras cómicas, entre otros ejemplos de obras en las que el texto se acompaña de "imágenes materiales"; o en el caso en que el propio texto forma esas imágenes referenciales como en los conocidos caligramas de Guillaume Apollinaire, Juan Larrea, Guillermo de la Torre y Gerardo Diego, entre otros cultivadores del género; ejemplos todos de la noción clásica de icono-texto.

Mi propuesta parte de dos presupuestos que relacionan las artes y la literatura: que la imagen visual es una categoría transversal a la literatura y a las artes, de manera que favorece incontables posibilidades de intercambio entre ambas; y que estos intercambios dieron origen al conocido dictum horaciano del que se vale Bécquer. Así, pues, esta (re)creación de la écfrasis tiene lugar, precisamente, por la relación referencial y representacional que establece el texto con el objeto visual. En ese sentido, como destaca Luz Aurora Pimentel, "no sólo la representación visual es leída o escrita --de hecho descrita-- como texto, sino que al entrar en relaciones significantes con el verbal, le añade a este último formas de significación sintética que son del orden de lo icónico y lo plástico, construyendo un texto complejo en el que no se puede separar lo verbal de lo visual: un icono-texto" (283). 
Siguiendo esta línea de análisis, Bécquer nos presenta una suerte de “(re)creación ecfrástica", que es el resultado, por una parte, de su sólido aprendizaje artístico, y por otra, de su capacidad discursiva para transformar el objeto visual en objeto verbal, creando tonalidades y perfiles descriptivos intensamente plásticos. Por otro lado, esta "(re)creación", que responde a la "mirada artística" de Bécquer y, por lo tanto, a su visión personalísima del objeto visual, no impide que existan otras tantas "(re)creaciones"--que son, por otro lado, "interpretaciones"-- como miradas se fijen en él, pero sólo a partir del objeto icónico-textual (re)creado por Bécquer. Tampoco deben descartarse, en este proceso de visualización interpretativa por parte del lector-espectador, sus propias experiencias culturales. Sin embargo, la labor primaria de reorganizar, seleccionar y reinterpretar el objeto visual--que le sirve a Bécquer de inspiración para tratar de conseguir el significado especialmente deseado, mediante la creación de una o más écfrasis-- no puede ser compartido por otras miradas, si esto no se hace desde la perspectiva única de poder contemplar y/e (re)interpretar el mismo objeto visual; esto es, como si se tratase de una "écfrasis referencial" --siguiendo la definición de Pimentel-- cuya existencia material autónoma pudiera permitir la contemplación del objeto real, es decir, un "cuadro", reconocido por todos los espectadores (narrador y lectores), desde una pluralidad interpretativa y reconstructiva. Es, en definitiva, la interpretación del espectadornarrador y, primeramente, la del artista, en el caso de Bécquer, lo que dicta la narración.

Asimismo, me propongo demostrar con detalles textuales cómo Bécquer se sirve de descripciones ecfrásticas para potenciar la "vivacidad" de su discurso narrativo, 
otorgándole a las palabras el carácter de "pintura verbal", logrando con ello efectos propios de la pintura. Deseo, por otra parte, llamar la atención sobre el hecho de que Bécquer toma como modelo, voluntaria o involuntariamente, el objeto pictórico, y elabora la intermedialidad según la composición y el esquema descriptivo del cuadro. Al ser éste el equivalente complementario respecto a su texto, Bécquer puede colocarlo junto al "cuadro", hacerlo comparable a él o susceptible de reemplazarlo o complementarlo, lo que le añade, entre otras cosas, nuevas perspectivas a la manera en que puede ser "leído" o "visto". Resulta también apropiado, dentro de una deseada pluralidad de miras, abordar este trabajo desde otras perspectivas. Las más evidentes son, sin duda, la semiótica, la iconología y los estudios culturales, pero caben otros recursos hermenéuticos que puedan resultar esclarecedores a los propósitos de mi trabajo.

La originalidad de este trabajo reside, precisamente, en el análisis de la capacidad discursiva por parte de un pintor-narrador, Gustavo Adolfo Bécquer, para (re)crear los ambientes de sus Leyendas, mediante la utilización de un nuevo lenguaje ecfrástico, trabajado --dentro de su novedoso concepto de prosa poética plástica-- con procedimientos reservados a la pintura, mediante representaciones de una gran intensidad pictórica, como correspondía a un artista de su formación.

En el primer capítulo, analizo la formación y valoración artísticas de los Domínguez Bécquer --José, Joaquín y Valeriano-- y su influencia en los medios artísticos sevillanos, así como el papel jugado por éstos en la formación plástica del joven Gustavo Adolfo, sobre todo por el "tío" Joaquín, su mentor artístico, y su hermano Valeriano, destacado pintor costumbrista y fiel acompañante de Bécquer, 
tanto en las exploraciones artísticas del paisaje español como en la labor común de escribir e ilustrar determinados escenarios y personajes. Esta formación artística de Bécquer es vital para entender su ulterior desarrollo como pintor-narrador, motivo por el que abundo en detalles sobre esta etapa. Incluyo, además, un análisis del concepto de écfrasis, su origen y tipologías, así como las distintas interpretaciones de ésta por algunos tratadistas contemporáneos: Lee, Spitzer, Hefferman, Eco, Krieger, Persin, Rifaterre, Pimentel, entre otros. La visión de estos críticos ayuda a entender el proceso de creación de las construcciones ecfrásticas de Bécquer, así como su particular visión e interpretación de este recurso intertextual. Por último, abordo la pintura como indiscutible ejercicio preliminar a la escritura de las Leyendas becquerianas.

El segundo capítulo se centra en las características y antecedentes de las Leyendas, los temas de éstas, así como en el interés de Bécquer por estos relatos tradicionales y populares, como parte de su concepción de la historia --la que utiliza como complemento de la tradición-- y de su "tradicionalismo artístico", de cierto carácter costumbrista. Asimismo, abordo el interés de Bécquer por las ruinas, los monumentos y templos religiosos, así como su huida "romántica" hacia otros tiempos y espacios, que avalan sus recurrencias artísticas a pintores como Lorrain, Rembrand y Murillo, a ciertos pintores románticos, así como al exotismo del arte indio.

Expongo, además, la teoría artística de Bécquer, recogida en algunos textos fundacionales, como las Cartas literarias a una mujer y las cartas de Desde mi celda, donde enfatiza la imposibilidad de expresar con palabras lo que la pintura es capaz 
de plasmar con mayor rigor. Termina el capítulo con una valorización de la Historia de los templos de España, un proyecto inconcluso iniciado por Bécquer a su llegada a Madrid, en el que la arqueología, la arquitectura y las artes en general juegan un papel preponderante en la recreación e interpretación del pasado, y le proveen la base para la elaboración de las Leyendas, como él mismo afirmara.

En el tercer capítulo expongo un análisis del exotismo oriental, que le sirve a Bécquer como punto de partida para ambientar las dos leyendas del llamado ciclo narrativo hindú. En ambos relatos, Bécquer describe un universo exótico y unas imágenes "orientalizadas" con los que construye su particular visión del Edén brahmánico. Se trata de construcciones icono-textuales, mucho más próximas al Oriente europeizado recreado por Chateaubriand, Nerval, o los románticos alemanes como Schlegel y Heine --y en abierta línea con la representación idealizada y eurocéntrica que se tenía de esa parte del mundo-- que a un Oriente "humanizado". Por lo mismo, esta pintura de una India lejana y exótica con influencias lorenianas y prerrafaelistas --es decir, (re)creaciones europeas-- en cuanto al papel de la luz y del color, entre otros elementos propios de la pintura, es más el resultado de una (re)creación artística que de una plasmación de la "realidad", a pesar de la información documental y gráfica de que se vale.

En el cuarto capítulo se analizan las leyendas de trasfondo medieval, que son de los relatos más reproducidos de las Leyendas becquerianas. Aquí abordo las características del medievalismo historicista --pero sólo de la vertiente artística del mismo-- y su importante papel en la configuración del paisaje romántico y posromántico de las Leyendas. En estos relatos, Bécquer se sirve de la luz, del color, 
así como de los elementos compositivos propios de la pintura romántica, prerrafaelista y simbolista, entre otras vertientes exploradas, para recrear el cuadro medieval que ambienta estas leyendas. Eso era parte de su interés --por demás, romántico-- de buscar en la evasión, en los lugares distantes y en las épocas pasadas, los elementos con que construir su peculiar forma de expresión literaria. Para ello, indago en el valor sugestivo del color utilizado por Bécquer, su "pincelada" libre, viva y llena de expresividad, así como en otras variantes del uso de la luz que buscan subrayar el carácter efectista y teatral de muchas de las descripciones ecfrásticas. Por otro lado, exploro, desde la perspectiva ecfrástica,la presencia de intermedialidades o interdiscursividades arquitectónicas, escultóricas y sonoras, igualmente importantes en el mundo narrativo de Bécquer.

En el quinto y último capítulo, analizo el resto de las Leyendas, algunas con indiscutibles características costumbristas o de difícil clasificación por la pluralidad de escenarios y discursos que contienen. En este sentido, hago un análisis de las características del costumbrismo español y su tendencia al realismo. Este es un aspecto muy discutido y poco valorizado del Romanticismo tardío en España, que no analiza los usos y costumbres que relata, sino que se limita a la mera "pintura" de los mismos. Por ello, se habla, casi sin excepción, del "cuadro de costumbres", que debemos interpretar, en el caso de las Leyendas, en su sentido más literal, pues se trata, esencialmente de pinturas que reflejan los ambientes regionales, tan caros a Bécquer. Esta "pintura" le era particularmente atractiva a Bécquer por dos motivos a los que me referiré: primero, por tratarse del quehacer pictórico familiar y del grupo de pintores sevillanos del entorno de los Domínguez Bécquer; y segundo, 
porque refleja, además, parte de sus propias indagaciones pictóricas, basadas en su interés por plasmar la identidad colectiva o Volksgeist por medio del nacionalismo y el regionalismo andaluz. Destaco en este capítulo, además, algunos rasgos definitorios de la Escuela Sevillana, que representa la vertiente más original del costumbrismo pictórico español. Indago, asimismo, en el concepto de "pintura de género", como exponente de personajes y ambientes cotidianos, pues Bécquer hace representar --de forma "realista", imaginaria, o combinando ambas-- escenas de interiores, callejuelas, iglesias, entre otras escenas de fuerte acento costumbrista. 


\section{NOTAS A LA INTRODUCCIÓN}

${ }^{1}$ El título con que se conoce este tratado no corresponde al original griego de politeía que aparece en Aristóteles. La traducción exacta de éste sería "régimen o gobierno de la polis (o de la ciudad)". Sin embargo, pasó al latín como Res publica, que tiene también este último sentido y fue empleado por Cicerón para rotular su obra sobre el mismo tema; del latín ha sido vertido con ese término al castellano, es decir, La República.

${ }^{2}$ Básicamente, la Poética consta de un trabajo de definición y caracterización de la tragedia y otras artes imitativas. Junto a estas consideraciones aparecen otras, menos desarrolladas, acerca de la historia y su comparación con la poesía (las artes en general), consideraciones lingüísticas y otras sobre la mímesis.

${ }^{3}$ Simónides de Ceos (Yulis, en la isla jónica de Ceos, actual Kea, ca. 556 a. C. Siracusa, ca. 468 a. C.), poeta lírico griego, creador de la mnemotecnia, tío del también poeta Baquílides.

${ }^{4}$ Quinto Horacio Flaco (Quintus Horatius Flaccus, Venosa, Basilicata, 8 de diciembre de 65 a. C. -Roma, 27 de noviembre de 8 a. C.), fue el principal poeta lírico y satírico en lengua latina. Los principales temas que trata en su poesía son el elogio de una vida retirada (beatus ille) y la invitación de gozar de la juventud (carpe diem), temas retomados posteriormente por poetas españoles como Garcilaso de la Vega y Fray Luis de León. Escribió, además, epístolas, la última de las cuales, dirigida $\underline{\text { A los }}$ Pisones (en latín, Epistvla ad Pisones), es conocida como Arte poética.

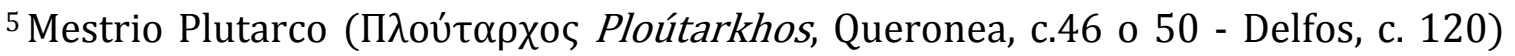
fue un historiador, biógrafo y ensayista griego.

6 "Poetry is speaking painting" y "painting is silent poetry". En latín, "Poema loquens pictura, pictura tacitum poema debet esse" (Cit. por Jennings Oates 93).

${ }^{7}$ El concepto resume la larga lucha de los pintores por hacerse tan respetables como ya eran los poetas. La idea surge en la antigüedad clásica y se va concretando en la medida en que dicha "hermandad" va ocupando un lugar importante en la crítica literaria y artística. Los conceptos de Simonides de Ceos y Quinto Horacio, ya enunciados, contribuyeron de forma determinante a fijar esta idea. 


\section{CAPÍTULO I}

\section{ANTECEDENTES ARTÍSTICOS EN LA CONSTRUCCIÓN DE LA ÉCFRASIS BECQUERIANA}

En tu álbum tienes mi dibujo: una reproducción pálida, imperfecta, ligerísima, de aquel lugar, pero que no obstante puede darte una idea de su melancólica hermosura. No ensayaré, pues, describírtela con palabras, inútiles tantas veces.

Cartas literarias, IV Gustavo Adolfo Bécquer

Gustavo Adolfo Domínguez Bastida (1836-1870), su verdadero nombre, nació en Sevilla, en el seno de una familia de renombrados pintores andaluces, que se destacaron como agudos intérpretes del costumbrismo local. Su padre, José María Domínguez Insausti, formado artísticamente en la prestigiosa Escuela de Bellas Artes de Sevilla, era ya conocido en su ciudad natal por el noble apellido flamenco ${ }^{1}$ de sus antepasados, los Becker, Vequer o Bécquer, establecidos en Andalucía a finales del siglo XVI. No debe resultar extraño, entonces, que un artista de la talla de José Domínguez Bécquer o José Bécquer, "cuyos cuadros de tipos y costumbres empezaban a llamar la atención de turistas ingleses y franceses, quisiese blasonar de su noble linaje" (Brown 7). Con el paso de los años, su primo Joaquín ${ }^{2}$, también destacado pintor costumbrista, y dos de sus hijos, Valeriano y Gustavo Adolfo, terminarían por adoptar el apellido flamenco, unido o no al de Domínguez, mucho más sonoro y, por lo tanto, más artístico.

En el panorama de conjunto de la pintura romántico-costumbrista española, los Bécquer ocupan un lugar de primer orden, encabezados por el patriarca de la 
familia, José Bécquer, quien, de acuerdo con Guerrero Lovillo, "llega a nosotros envuelto en aquella magia, popular y señorial a la vez, que emana del magnífico retrato que le rindió su amigo [Antonio María] Esquivel... Su quehacer artístico participaba también de aquellas dos categorías. De pura extracción popular su arte, sabía infundirle una gracia especial, conjugando una fina nota de pintoresquismo con una sutil elegancia, clave de su éxito" (11). También, como acota Narciso Campillo, amigo y primer biógrafo de Bécquer, “José Domínguez Bécquer era pintor aventajado en el género de costumbres" (Cit. por Díaz 19), lo que avala la reproducción gráfica de muchas de sus obras, ya sea en historias ilustradas, libros de viaje y guías turísticas, tan en boga a partir de 1830. A esta labor editorial, debemos aunar su copiosa obra plástica, adquirida fundamentalmente por los jóvenes visitantes extranjeros del grand tour --una especia de formación artística y vital para "ver" y "vivir" mundo, como se decía-- llegados a Andalucía para conocer algo de la civilización oriental, y cuya existencia prueba el detallado inventario de obras que el propio José Bécquer consignaba en su conocido "Libro de cuentas".

El viaje a Andalucía, desde luego, no era el viaje al Oriente, pero era lo más cercano a éste para muchos viajeros del siglo XIX. Como afirma Villafranca Jiménez, "la imagen de España se revaloriza como destino y meta de viajeros que pretenden encontrar en estas latitudes una suerte de oriente de proximidad" (16), atraídos por el ambiente exótico de la región y, en particular, por los vestigios de la cultura árabe. En La Sevilla de Richard Ford, Francisco J. Rodríguez Barberán deja una semblanza sobre la ciudad en ese siglo: "Sevilla es una referencia para la Europa de ese tiempo, una meca para la sensibilidad romántica por formar parte de ese 'Oriente cercano y 
confortable' que Andalucía ofrecía a los viajeros menos atrevidos, y que encontraban en Granada, Córdoba o Sevilla, una versión más asequible de El Cairo o de Bagdad" (113). El tipismo andaluz --representado por bandoleros, toreros y gitanos-- era, también, a tenor de la impresión de los viajeros y de los habitantes de la región, la esencia del país; de ahí el interés por "los tipos autóctonos" (Fernández Lacomba 33). Como destaca García Felguera en Pintura andaluza, "España era el 'Oriente más a mano' para el resto de los europeos. La parte más 'oriental' de Occidente funcionaba como un lugar exótico, tan exótico como el norte de África (en un paralelismo que no dejaban de señalar los viajeros)" (18). Ante esa diversidad que encuentran los viajeros, una parte del país, Andalucía, prevaleció sobre las demás. Fue en Sevilla, durante el primer tercio del siglo XIX, donde comienza a construirse la imagen romántica, pintoresca, exótica y, muchas veces, deformada de la realidad andaluza --el tópico andaluz--, que terminaría siendo la de toda España. La potencia de esta imagen ilusoria fue tal, que anuló a todas las demás. A esta construcción falseada de la realidad, pero comprensible en el contexto histórico, contribuyeron tanto andaluces como los propios extranjeros.

Como señala, además, García Felguera:

El hecho es que en los años treinta, y en Andalucía, se dan cita un número importante de británicos cultos, sensibles, inquietos y curiosos, amigos de escribir, pintar y comprar cuadros y dibujos; al calor de esas relaciones amistosas entre artistas andaluces por un lado y coleccionistas y pintores británicos por otro, se empieza a desarrollar la llamada pintura costumbrista andaluza. (13) 
En este marco de interés histórico-artístico, la valoración de José Bécquer como pintor era ampliamente reconocida, como demuestran los testimonios de la época. Hacia 1837, es decir, a sólo un año del nacimiento de Gustavo Adolfo Bécquer, se publica en Londres una obra de marcada orientación costumbrista: The Andalussian Annual for MDCCCXXXVII. En su prólogo, podemos leer el siguiente comentario: "The portraits and costumes have been painted at Seville by José Bécquer, a well-known resident artist, whose fame is already established in every part of the Peninsula" (Cit. por Brown 9). Asimismo, Rica Brown destaca un comentario de José Amador de los Ríos --publicado en Sevilla pintoresca (1844)-sobre la galería de pinturas de Don José Díez Martínez: “cuatro son los cuadritos que conserva el señor Martínez de este malogrado joven, que tanta Gloria prometía en el género a que se había dedicado. Todos [sic] cuatro lienzos representan escenas andaluzas bellamente pensadas y pintadas con exquisito gusto" (8).

José Bécquer ilustró también el primer tomo de la edición bilingüe de España artística y monumental. Vistas y descripciones de los sitios y monumentos más notables de España, una obra en tres tomos publicada por Pérez Villaamil, entre 1842 y 1850, que refleja el interés romántico, por demás de fuerte acento costumbrista, por describir los monumentos arquitectónicos, y con ellos las esculturas y las pinturas que los complementaban, así como las costumbres que la modernidad amenazaba con relegar al olvido, si no destruir. Es muy posible que Bécquer haya encontrado en esta obra de Villaamil, ilustrada por su padre, un antecedente válido para su proyecto de la Historia de los templos de España y para las Leyendas. 
Debemos, pues, reconocer, a la luz del interés que despiertan las obras de José Bécquer entre sus contemporáneos, un talento singular en la elaboración de toda una galería de tipos y costumbres que ilustran éstas y otras obras de "género"; una definición bastante ambigua, utilizada en la cita anterior por José Amador de los Ríos, que se aplicaba a las escenas de costumbres, temas que, durante mucho tiempo, se consideraron como menores, pero que en el siglo XIX van a renacer con la nueva estética romántica, sobre todo con la pintura de escenas de la vida cotidiana, generalmente de las clases populares o de la burguesía. En estas obras se reproducen fiestas, bailes en los castillos, tareas domésticas, labores del campo o de los oficios artesanales, cacerías --entre otros temas que tratará Bécquer en sus Leyendas--, cuyos antecedentes, sin embargo, se remontan a las miniaturas de algunos códices medievales, y más tardíamente a la pintura de los países del norte de Europa, de Flandes y de los Países Bajos, fundamentalmente. En todo caso, es innegable que José Bécquer tenía un talento y una gracia especiales para representar los ambientes costumbristas en sus obras, a las que supo infundirles el color local, lo pintoresco ${ }^{3}$, en definitiva, que reclamaban los viajeros de la época, pero dentro de ciertas normas de finura y elegancia en el tratamiento que lo distinguen del "pintoresquismo" popular.

Pintores y escritores de las más disímiles geografías, como David Wilkie, John Frederick Lewis, David Roberts, George Borrow, Washington Irving, Prosper Mérimée, Théophile Gautier, Eugène Delacroix, y quizás el más importante para España, Richard Ford, entre otros muchos, se dieron a la tarea de reproducir los ambientes exóticos españoles, sobre todo los andaluces, sus tipos y costumbres, 
como parte de una visión romántica del mundo y de una nueva manera de "ver" e interpretar el paisaje que no pudo pasar inadvertida para Bécquer. Tal interés en Andalucía se tradujo en un movimiento cultural de cierta relevancia, sobre todo en el campo de la plástica. Para ese entonces, nos aclara Rica Brown, Sevilla ofrecía a sus curiosos visitantes "[s]us galerías de arte, sus importantes monumentos romanos, árabes y cristianos, además de sus rincones, paseos y jardines" (13).

Es visible la huella que muchos de estos escritores y pintores del grand tour dejaron en la obra de Bécquer. Queda abierta, por otro lado, la interrogante sobre la influencia que estos viajeros románticos ejercieron sobre los artistas y escritores españoles, pero todavía mucho más si nos referimos hasta dónde subsisten, a manera de apropiaciones, intermedialidades o intertextos, en las obras de otros escritores y pintores contemporáneos con José Bécquer, y hasta posteriores a él. Sin duda, el panorama cultural andaluz --y muy particularmente el literario y el pictórico--se amplía considerablemente gracias a estas ricas influencias del grand tour. Para González Troyano,

Andalucía, de cultura tan sobreabundante como heterogénea, ofrecía un amplio abanico de sugerencias y opciones. Una historia cargada de vaivenes, con una gran superposición de pueblos conquistados y conquistadores, había provocado un variado mestizaje, a lo que se unía una gran polarización social, con creaciones artísticas muy apreciables en cada uno de sus extremos: en el popular y en el culto. Persistían, además, restos de ruinas suficientes para evocar, en un mismo espacio, el conglomerado de tres o cuatro civilizaciones 
superpuestas. Y en muchos casos aún pervivían costumbres medievales junto a otras modernas. Contrastes, por tanto, a la vez, de miseria y de grandeza..., dependiendo en gran medida de lo que el viajero prefería ver, o, en la mayoría de los casos, de las emociones que prefiriera relatar, pintar y escribir a su regreso. (17-18)

Todo este trasfondo arqueológico andaluz, que interesó vivamente a Bécquer desde su adolescencia, era también el marco ideal para sus narraciones fantásticas, estructuradas, casi siempre, alrededor de algunas ruinas, de monumentos arquitectónicos o escultóricos representativos de las distintas culturas que se asentaron en su territorio, pero que terminaría por hacerse extensivo a otras regiones que también sirvieron de escenario a sus leyendas. Díaz Plaja, en su Introducción al estudio del Romanticismo español, acota que "Bécquer conoce el valor emotivo de las ruinas. Digamos que también valora y estima a su más representativo pintor, Claudio de Lorena, quien, creador del paisaje melancólico moderno, sabe 'ver todo el misterio, con toda la indefinible vaguedad que lo embellece'” (80). Sin embargo, lo que más valora Bécquer de Claudio Lorena es el tratamiento de la luz como principal elemento sensible, y como el medio que atrae y envuelve al espectador en la atmósfera deseada.

Por la importancia que tiene para la formación artística de sus dos hijos, es importante destacar la labor pedagógica de José Domínguez Bécquer, quien no sólo alcanzó una sólida reputación como artista, como ya hemos señalado, sino también como maestro de pintores en su Sevilla natal. Por su taller pasaron, en calidad de alumnos, una larga nómina de conocidos artistas andaluces, entre los que se hallaba 
su primo Joaquín, así como Eduardo Cano y Manuel Rodríguez de Guzmán, entre otros. A esta circunstancia, agreguemos su capacidad para agrupar a su alrededor a toda una generación de escritores y artistas nacionales y extranjeros como algunos de los ya mencionados.

En una semblanza sobre José Domínguez Bécquer, aparecida en la edición de 1966 de la obra de Richard Ford, Gatherings from Spain, Ian Robertson nos dice lo siguiente sobre el artista: "[A] Sevillian costumbrista artist, who portrayed characteristic genres scenes for both Julian Williams, the British Consul, and the connoisseur Franck Hall Standish (1799-1840), whose residence in the Plazuela de San Isidro [Richard] Ford had rented during the Winter of 1830-31. It was probably at this time that [José] Bécquer painted three full-length portraits of Ford" (331). Por otro lado, según declara Richard Ford, "Williams era, con mucho, el mayor juez de arte español en Europa; su colección era la primera en importancia" (Cit. por García Felguera 14). Este juicio de Ford sobre el conocimiento de Williams, confirma, una vez más, la calidad artística de la obra de José Bécquer.

Entre otros juicios críticos sobre el arte de José Bécquer, destaca la siguiente afirmación de Robert Pageard que es importante a los efectos de este trabajo:

Me parece ser Gustavo Adolfo Bécquer en literatura lo que su padre en pintura: en primer lugar, un artista del movimiento, de la luz, de la gracia, de la ligereza, del ademán breve y vivo. Su arte de dibujante se relaciona con el de José Bécquer por el predominio de la figura y del gesto, pero se diferencia [de aquél] por una acostumbrada huida al mundo de la fantasía personal. (37) 
Resulta interesante esta comparación, no sólo entre José Bécquer, pintor, y Gustavo Adolfo Bécquer, escritor, sino entre ellos dos como pintores. La crítica suele destacar las cualidades de dibujante delicado de José Bécquer, especialmente dotado para fijar la vida de los rostros y los cuerpos en movimiento, así como el interés que manifiesta para los juegos de luz y sombra, en particular para esa luz que inunda los planos lejanos. Esta peculiaridad en el tratamiento de la luz, sin duda influencia de Murillo, un artista con infinidad de seguidores en Sevilla, la veremos también en las Leyendas. Por último, se ha hablado de su capacidad para traducir el ambiente de los grupos, reuniones y ceremonias; "naturalidad y viveza se manifiestan en todos los pormenores" (37), destaca Pageard. No se mencionan sus cualidades de colorista, quizás mucho más importantes en su hijo Valeriano, pero igualmente notorias en el caso de José Bécquer.

Gustavo Adolfo Bécquer, es importante destacarlo, no permaneció ajeno a las influencias paternas. La visión romántica del artista, y también del escritor, se centrará en los paisajes --verdaderos escenarios pictóricos de gran importancia en las Leyendas--, en la función de la luz y del color, así como en los tipos autóctonos, y en todo aquello que pudiera catalogarse como "pintoresco" en su sentido menos restrictivo; y su imaginación llega a desbordarse por completo en el momento de evocar la realidad que se halla ante sus ojos. Resulta interesante descubrir en la obra pictórica del maestro José Bécquer la simiente de la plenitud plástica y sensorial que alcanzará la prosa de Bécquer en sus leyendas, aun cuando la temprana muerte de José Bécquer, en 1841, y los apenas cinco años con que contaba Gustavo Adolfo en esa fecha, no parecen justificar una influencia directa del padre 
sobre la labor pictórica y narrativo-plástica de su hijo. Sin embargo, no podemos obviar que el curso de los acontecimientos tras la muerte del padre va a suponer para Bécquer un contacto más directo con el entorno de aquél, sobre todo bajo la protección del "tío" Joaquín, su mentor artístico, heredero de las enseñanzas pictóricas --y hasta de la abundante clientela-- de José Bécquer. La influencia artística del padre le llega, digamos, filtrada a través del “tío” Joaquín.

Por otra parte, llegado el momento de continuar los pasos de su padre como artista, vemos que Gustavo Adolfo no ingresa directamente en el taller de Joaquín Domínguez Bécquer, sino que lo hace en el taller del conocido pintor sevillano Antonio Cabral Bejarano, en 1849. Al respecto, Campillo afirma que, "a pesar de las circunstancias de tan próximo parentaje [sic] ingresó éste [Gustavo Adolfo] a los catorce años en el taller de Bejarano" (Cit. por Brown 34). Campillo equivoca la fecha de nacimiento de Bécquer. En realidad, entró a los trece años. La mayoría de los biógrafos, sin embargo, no han explicado esta aparente anomalía, aunque parece ser, por lo que afirma Rica Brown, que "para la carrera de pintor se consideraba necesario primero un aprendizaje de dibujo, arte en el que se especializaba Don Antonio" (34). Este comentario viene a corroborar que el adiestramiento artístico de Bécquer se atenía a un plan formal y estructurado como el que seguían otros estudiantes de arte.

Antonio Cabral Bejarano tenía su estudio en el Museo Provincial de Pintura, alojado en el convento de la Merced. Allí fungía como conservador del museo, y entre sus varias tareas, tenía a su cargo la restauración de las obras de arte que así lo requirieran. Los Cabral procedían de una antigua familia de pintores sevillanos, y 
tres de los hijos del propio Antonio, los Cabral Aguado, sobre todo Manuel, alcanzarían cierta notoriedad en el panorama artístico sevillano. En su estudio biográfico sobre Bécquer, Pageard menciona que Antonio Cabral Bejarano había sido "asistente en la escuela de Bellas Artes y enseñaba la perspectiva en la clase de arquitectura" (56). Por entonces, José Bécquer se formaba artísticamente en la academia sevillana. Se sabe, además, por José Gestosa y Pérez y por algunos biógrafos de Bécquer, que también Valeriano había asistido al taller de Cabral Bejarano. No está claro, sin embargo, si el propio Valeriano llevó a su hermano hacia ese mismo taller o si Joaquín Domínguez Bécquer se encargó de guiarlo él mismo, como aprendizaje previo a la entrada en su propio taller de pintura, como señala Rica Brown. Los dos hermanos eran inseparables, "eran uña y carne" (14), de acuerdo con Rubio Jiménez. En todo caso, parece claro que Cabral Bejarano conocía la procedencia de los hermanos, a tenor de la importancia del apellido Bécquer en los ambientes artísticos sevillanos, y hasta quizás por haber mantenido una relación artística, si no amistosa, en los tiempos en que coincidió con José Bécquer en la academia sevillana.

Sobre la enseñanza académica de las artes en Sevilla, Bécquer hace una referencia a la escuela de Bellas Artes en las notas necrológicas que escribió sobre su hermano Valeriano: "Al par que los estudios un poco rutinarios de las academias de Sevilla, seguía él libremente pintando y dibujando por su cuenta, apuntando ligeramente del natural cuanto veía o trazando al capricho lo que pensaba" (ㅁbras completas 506), lo cual refleja, hasta cierto punto, su propio punto de vista sobre los métodos de enseñanza de la propia escuela; "un poco rutinarios", dice. En cuanto a 
Bécquer, Nombela nos deja una semblanza de este aprendizaje: "Pero si en la clase copiaba del yeso y del natural, en su casa se dedicaba Bécquer a reproducir en papel, como los veía su imaginación, los tipos y las escenas de las novelas, poemas y poesías que continuaban siendo su lectura predilecta" (Cit. por Brown 34). Nombela, sin proponérselo, nos deja la prueba de una práctica artística que terminaría por permear su obra, sobre todo su prosa: la recreación plástica de ambientes y personajes, ejercicio que bien pudiera haber sido la base de sus recreaciones ecfrásticas, tal y como las analizaremos en este trabajo.

Estos dos años pasados en el estudio de Cabral Bejarano aportarían a Bécquer, primero, la satisfacción de un aprendizaje de arte en un convento-museo, “en medio de la más hermosa colección de Murillos del mundo, de las más típicas obras de Zurbarán y de gran número de lienzos de Valdés Leal, es decir, en medio de la ternura del primero, del misticismo y de la perfección pictórica del segundo, y de la ardiente poesía religiosa del tercero" (Pageard 57). Segundo, la destreza en el dibujo de personajes, en la composición de los grupos animados, en la perspectiva; habilidades en las que destacó, además, el maestro José Bécquer. Por último, la presencia de un maestro humanista que estimulaba las capacidades de sus discípulos, tanto en el campo de la fantasía, como de la realidad, pero dentro de un marco de disciplina que les dejaba cierto espacio para entregarse a sus ideas creadoras, aunque fuera del ámbito académico. Esto explica, de alguna manera, que Bécquer asociara la disciplina académica con lo "rutinario", para usar el término empleado por él mismo, en contraste con las libertades de creación fuera de ésta. Su espíritu de artista se rebelaba contra los moldes académicos de los talleres. 
Parece ser que en 1851, una vez logrado cierto dominio de las técnicas de dibujo con Cabral Bejarano, Bécquer pasó a unirse a su hermano Valeriano, que ya se encontraba en el taller de pintura de Joaquín Domínguez Bécquer, situado en el Alcázar. Allí, en un ambiente muy distinto del taller de Cabral Bejarano, trabajaban los dos hermanos. Es muy probable que en esta etapa compartida de preparación académica, bajo la tutela del "tío" Joaquín, se haya consolidado la estrecha colaboración artística y la comunión de intereses artístico-literarios entre los hermanos. De acuerdo con Heliodoro Carpintero, "ambos hermanos están unidos por la sangre, por los rumbos paralelos de sus vidas y por sus gemelos anhelos de arte" (46). Sin embargo, el talento de Valeriano por la pintura parece haberse manifestado mucho más tempranamente, según apunta el propio Bécquer:

Es una puerilidad, pero yo recuerdo que siendo muy chico nos quitaban la luz después de acostados, y Valeriano, las noches de luna, abría el balcón y dibujaba a aquella claridad dudosa. Ya desde chico pintaba todo lo que nos sucedía y retrataba en papeles y libros a las gentes que íbamos conociendo... Ni su estilo, ni su manera, ni su color, se parecía a nada de lo que había visto allí [Se refiere Bécquer al taller del tío" Joaquín] y siempre conservó su sencillez y una espontaneidad que lo hacían original. (Obras completas 506)

Llama la atención el vocabulario crítico de artista empleado por Bécquer para enjuiciar la obra de su hermano, destacando, sobre todo, su originalidad con relación a lo aprendido en el taller del "tío" Joaquín. No debe, pues, extrañarnos esta aproximación crítica de Bécquer dada su formación artística, pero, además, "el 
artista del siglo XIX... se encuentra en condiciones de teorizar sobre su propia obra y en tal sentido podrá replicar a la propia crítica o ejercitar la crítica él mismo" (Hernando 73). La valoración general que nos deja Bécquer sobre la enseñanza académica, tanto en el taller de Cabral Bejarano como en el de Joaquín Domínguez Bécquer, no parece arrojar un juicio muy positivo sobre ésta, aunque es evidente la base técnica que adquirieron ambos hermanos. Incluso en el taller del "tío" Joaquín, ambos hermanos participarán en las tareas de restauración pictórica del Alcázar, lo cual supuso, desde el punto de vista formativo, un acercamiento plural a la obra de otros artistas. Este proyecto fue organizado por Joaquín Domínguez Bécquer, debido al prestigio que ya había alcanzado como pintor, por lo que también se le conoce en la historia del arte como "el pintor del Alcázar".

Creo importante destacar aquí que los antecedentes artísticos de Gustavo Adolfo Bécquer hay que buscarlos, en primer lugar, en la producción pictórica del entorno familiar, particularmente de su padre, pero también en la obra de los pintores que conformaban el círculo artístico de los Bécquer en Sevilla: Esquivel, Pérez Villaamil, entre otros, sin excluir al "tío" Joaquín, y a la influencia artística de su hermano Valeriano, sobre la que se han manifestado algunos críticos. Berenguer Carisomo, por ejemplo, argumenta que "[l]a amistad fraternal de Valeriano se proyecta en no pequeña porción de la prosa becqueriana, en lo que ésta tiene de copia literaria, de versión objetiva de las cosas. Muchas páginas de Bécquer están pensadas 'pictóricamente', y hay con ello otro atisbo de soluciones estéticas muy raras entonces en España" (62). Debemos aclarar, primeramente, que "la amistad fraternal" a que alude Carisomo, debe interpretarse mejor como el fruto de una 
estrecha relación artística. No hay que dejar a un lado la propia formación plástica de Bécquer en las academias sevillanas, a las que ya hemos aludido, ni sus propias experiencias pictóricas, tanto en la creación propiamente dicha, como en la asimilación de técnicas pictóricas de otros artistas. Por otro lado, lo que Carisomo destaca como "atisbos", es, a no dudarlo, la característica fundamental de la prosa "plástica" becqueriana. No sólo se trata de páginas "pensadas pictóricamente", sino de descripciones ecfrásticas elaboradas por un artista; por lo tanto, resueltas en términos pictóricos; de ahí que el objeto visual destaca sobre el objeto verbal. Al respecto, Carol P. James hace notar lo siguiente: "when the qualities of pictures and words are compared, a hierarchy develops: pictures are primary, present, clear; words are secondary, abstract, mediated" (458).

También, en el campo de las influencias notables, debemos mencionar, sin lugar a dudas, a Claude Gellée o Claude Lorrain --el ya mencionado como Claudio de Lorena--, así como a Rembrandt y a Murillo; este último un referente obligado en el ámbito sevillano. En la Historia de los templos de España, Bécquer apela a la obra de estos artistas y a su particular forma de interpretar la luz y el color. En las Leyendas, por otra parte, la influencia de estos artistas destaca en las descripciones ecfrásticas. No deben excluirse, sin embargo, otras influencias artísticas, intermedializadas, como es el caso de los pintores barrocos andaluces y de los románticos, entre otros influjos.

En su estudio sobre José Bécquer, el primer trabajo monográfico sobre este artista, Jesús Rubio Jiménez señala que “[a]ludir al papel jugado por José Domínguez Bécquer... en la conformación de la imagen romántica de Sevilla y aun de España es 
un lugar común de la crítica, pero nunca se ha ido más allá de la afirmación tópica para descubrir y describir su verdadero alcance" (11). Debemos señalar, no obstante, que tanto a José Bécquer como a su primo Joaquín y a su hijo Valeriano, se les reconoce una importancia crucial dentro de la pintura romántico-costumbrista española. Su obra artística fue el resultado de la cimentación de aportes de la tradición plástica española, sobre todo la andaluza, así como de las influencias de artistas extranjeros, ingleses, franceses y flamencos, fundamentalmente, sin eludir, desde luego, la visión personal de cada uno de ellos.

Queda, pues, confirmada, a la luz de lo ya expuesto, la solidez académica de los Domínguez-Bécquer y el prestigio alcanzado por éstos en el panorama artístico andaluz; además de la relación de Gustavo Adolfo Bécquer con el círculo familiar integrado por el "tío" Joaquín y por su hermano Valeriano, así como con el mundo de las artes plásticas en los ambientes humanistas sevillanos. Esta es, en mayor medida, la base sobre la que descansan las descripciones ecfrásticas bequerianas. A este respecto, se hace necesario abundar sobre el concepto de écfrasis, su origen y los distintos tipos de écfrasis que analizaremos en las Leyendas.

\section{I.1. El concepto de écfrasis: origen y tipologías}

La écfrasis ha sido definida y redefinida a lo largo de los siglos, aunque conservando, en esencia, el significado inicial que le otorgaron los retóricos griegos. En sus inicios, la ekphrasis (del griego antiguo Ěk $\varphi \rho \alpha \sigma \iota$, término formado por los vocablos $e k$, afuera y phrasein, decir, proclamar, pronunciar), así como sus variantes castellanizadas de ekfrasis o écfrasis, tal y como la usaremos en este trabajo, es un tipo de intermedialidad que se traducía como "explicar hasta el final", intensa y 
extensamente, un objeto o artefacto de arte, real o ficticio. El Oxford English Dictionary la define así: "a plain declaration, description or interpretation of a thing" (831). Desde una perspectiva teórica y crítica, debemos considerar otras definiciones, a fin de elaborar una definición mucho más inclusiva del concepto que pueda abarcar la particular interpretación de Bécquer. En el Dictionary of Art, editado por Jane Turner, la écfrasis se define como "a vivid description intended to bring the subject before the mind's eye of the listener... The author displayed his skill with words as well as expressing the qualities of the work described" (128). Se amplía aquí el concepto para señalar aspectos que considero importantes:

An ekphrasis generally attempted to convey the visual impression and the emotional responses evoked by the painting or building, not to leave a detailed, factual account. In an ekphrasis of a painting the author does not confine himself to the specific moment represented, but was free to discuss the general narrative context, referring both forwards and backwards in time. (128)

En el centro de todas las definiciones de écfrasis que analizaremos en este trabajo, se halla la idea de percepción de un objeto artístico con dimensiones plásticas, lo cual supone un complejo ejercicio descriptivo para el escritor que desea "convertir" o "traducir" a palabras una representación no verbal, exista o no el referente fuera de la ficción, es decir, tanto si se trata de una obra material o inmaterial. Para Bécquer, desde su perspectiva de pintor, la écfrasis iba más allá de la mera descripción del objeto visual por medio del objeto verbal. Por sobre todo, debía primar el "elemento pictórico" sobre el objeto verbal, indispensable, de acuerdo con 
su formación artística, para la comprensión del texto literario, ya que éste se veía así potenciado por la "interpretación plástica" de un artista. De hecho, nos encontramos ante un "texto pintado", excluyendo las valoraciones metafóricas del concepto.

Para reafirmar esto, debemos destacar que Bécquer, desde sus inicios como escritor, puso de manifiesto su interés por las artes, dando prioridad a la construcción de referentes no verbales, esto es, de descripciones ecfrásticas, cuya función principal era acrecentar plásticamente la significación de un texto literario mediante imágenes intermedializadas: las écfrasein o écfrasis, entendidas como recursos capaces de reproducir las cualidades propias del objeto visual, del "cuadro" o de la representación plástica, y de lograr su "visibilidad" mediante la palabra. Dentro de la estética becqueriana, estos recursos plástico-descriptivos debían “compensar"--por paradójico que esto pudiera parecer a primera vista-- no sólo la "insuficiencia" o "inutilidad" de las palabras para describir imágenes pictóricas, tal y como las define el propio Bécquer, sino que debían reproducir, además, las impresiones e ideas que éstas despiertan en el lector-espectador, en el sentido que les otorga la tradición clásica horaciana de ut pictura poesis (como la pintura, así es la poesía).

Las primeras alusiones a la écfrasis las encontramos en Hermógenes de Tarso (s. II-III), dentro de las ekphrasis progymnasmata (o écfrasein progimnásmata), como parte de los ejercicios de retórica que se enseñaban a los alumnos en la antigua Grecia, y que los preparaba para expresarse con precisión y elegancia. Esto suponía un difícil ejercicio de concreción y síntesis. Sin embargo, como señala Patrica A. Ward, "[t]he most influencial precept in relating the arts was still 
Horace's ut pictura poesis'... Eighteenth-century taste for descriptive poetry, as well as the prevailing view of the imagination as an associate power, linking images, contributed to the comparisons between poetry and painting" (115). El dictum horaciano resume la capacidad de traducir, y la posibilidad de intercambiar, las cualidades de un objeto visual por uno verbal. Así, en la Epistolae ad Pisones, Horacio declara:

Ut pictura, poesis: erit quae, si propius stes, Te capiat magis, et quaedam, si longius abstes; Haec amat obscurum, uolet haec sub luce uideri, Iudicis argutum quae non formidat acumen; Haec placuit semel, haec deciend repetita placebit. $(70)^{4}$ Es sabido, además, que la base del Ars Poetica de Horacio es la Poética de Aristóteles, de ahí que su reflexión sobre las relaciones entre pintura y poesía se apoye en la idea de éste según la cual "el poeta, al igual que el pintor o cualquier otro hacedor de imágenes, es un imitador" (126). Siguiendo esta línea de análisis, M. H. Abrams argumenta lo siguiente: "[I]n many mimetic theories everything is comprehended in two categories, the imitable and the imitation" (8). La orientación mimética, esto es, la idea de que el arte es una imitación de la naturaleza, es, posiblemente, una de las teorías estéticas más antiguas que conocemos. El propio Abrams corrobora la importancia de esta relación cuando señala: "Trough most of the eighteenth century, the poet's invention and imagination were made thoroughly dependent for their materials --their ideas and 'images'-- on the external universe and the literary models the poet had to imitate" (21). 
Por otra parte, el propio Aristóteles llega a manifestar que "las palabras habladas son símbolos... o impresiones del alma; [y] las palabras escritas son los signos de las palabras habladas" (115). Aristóteles utiliza los términos de símbolo y signo, conceptos que han generado todo un cúmulo de controversias. Sin embargo, lo que hasta el presente está dilucidado es que cualquiera de ellos trata de simbolizar al concepto o referencia, de una parte, y, de otra, de aludir al referente, a la realidad. Aristóteles está, entonces, mucho más cerca del concepto pictórico que le otorgaban las culturas orientales a la escritura, que la definían como el habla pintada. En ese sentido, toda experiencia visual puede tener infinidad de interpretaciones, y cada texto es posible recrearlo mentalmente por medio de imágenes. Para la estética visual china, dentro de la visión oriental aludida, las relaciones entre poesía, caligrafía y pintura son de una importancia estética crucial. En The Alphabet Makers, Hyatt Moore afirma: "Chinese writing began as pictures. The earliest characters known... were on oracle bones. Some that were found still resembled the things they represented. But even then it was a full writing system" (57). La práctica de integrar estas tres formas artísticas, conocidas como "sanchiieh" o las tres perfecciones, se origina durante las dinastías Sung y Yuan, y desde entonces ha originado un amplio debate en torno a la integración de las artes.

Por otro lado, tomando como epígrafe el símil horaciano, el escritor francés Jean-Baptiste du Bos destaca que el arte no puede ser únicamente bello, sino que debe emocionar al espectador. Así en su obra: Réflexions critiques sur la poésie et sur la peinture (1715) señala: "On mérite le nom depoète en rendant l'action que l'on traite capable d'émouvoir" (I-24). 
En ese sentido, la capacidad de emocionar era un factor de gran importancia para los románticos en los albores del siglo XVIII, y todavía mucho tiempo después; y agrega más adelante:

"Le sublime de la poésie et de la peinture est de toucher et de plaire, comme celui de l'éloquence est de persuader. Il ne suffit pas que nos vers soient beaux, dit Horace en style de législateur, pour donner plus de poids à la décision; il faut encore que ces vers puissent remuer les coeurs et qu'ils soient capables d'y faire naître les sentiments qu'ils prétendent exciter". (II. 1)

La obra de Du Bos marcó un giro en el pensamiento estético del Siglo de las Luces. Esta capacidad de emocionar, valiéndose de la fusión de la pintura y la poesía, tan ajena aparentemente a la razón que prevalece en este siglo, todavía tendrá un impacto mucho mayor durante el Romanticismo, precisamente por esa aproximación a lo "sublime". Al igual que la obra de Longino, On the sublime, que junto con la Poética de Aristóteles es una de las principales obras de crítica literaria de la Antigüedad clásica, las Réflexions del abad Du Bos logran un espacio en la concepción artística del Romanticismo, porque recogen, de cierta manera, el símil horaciano, y porque en ellas se manifiesta una profunda relación entre ilusión y ficción, esto es, entre pintura y poesía. No hay duda de que Bécquer recoge el legado de los clásicos y lo proyecta como estilo propio, ya fuese de forma consciente o no, aunque podemos intuir que pudo llegarle a través de sus lecturas; de Chateaubriand, sobre todo, o bien por el deseo de fundir sus dos vertientes creativas; esto es, la pintura y la literatura. 
Sobre la estrecha relación entre estas dos artes, Rensseler W. Lee afirma:

"So deeply rooted, in fact, was the association of painting with poetry that it is not unusual to find the critics referring in a way that startles the modern reader to poets as painters; and if not with equal bluntnerss call painters poets, at least they are almost unanimous in asserting that painting merits serious consideration as a liberal arts only by virtue of its likeness to poetry". (3)

Si aplicamos este aserto de Lee al caso de Bécquer, escritor eminentemente visual, no deben desligarse en el análisis la forma --y sus descripciones ecfrásticas-de la idea; y esta interacción sígnica se encuentra tan profundamente integrada en su obra, que resulta imposible desligar ambas vertientes 5 , a pesar de ser Bécquer un escritor profundamente subjetivo. La propia interacción de las artes, de la pintura y de la poesía, en particular, nace con las artes mismas. Si retomamos los conceptos de los clásicos, constataremos que estas relaciones entre imágenes y palabras, o diálogo interdisciplinar, han sido analizadas desde siempre en su interrelación semiótica. Así, Talens afirma que "todo lenguaje que sirva de medio de comunicación está constituido de signos, en última instancia, y estos signos poseen unas reglas definidas de combinación que se formalizan en determinadas estructuras con un modo propio de jerarquización" (31).

Los antiguos egipcios utilizaban un sistema de símbolos, los jeroglíficos, que era la única forma posible de contar historias mediante la representación gráfica de palabras y frases. Otras culturas se valieron también de signos para "escribir", "pintar" o "grabar" sus historias, que muchas veces quería decir lo mismo, lo cual 
refleja el carácter pluridimensional del concepto de escritura. El propio término scribere tiene una raíz indoeuropea que nos transmite la idea de cortar o entallar. Y la misma idea de corte está presente en el vocablo griego grapho, que significa "arañar", "rasgar", pues se refería al soporte sobre el que se escribía. Esta convergencia semántica apoya la idea de que escribir estaba asociado al acto de cortar, arañar, grabar o ilustrar gráficamente en el soporte, como era característico de muchos de los sistemas antiguos de escritura. Núria d'Asprer señala que esta confluencia "también remite a la experiencia sintética de la escritura en sus orígenes, cuando era pictográfica e ideográfica y no estaba destinada a transcribir el lenguaje verbal" (1). Con el paso del tiempo, y con la invención de la escritura sobre la base de signos, ambas artes, pintura y literatura, se separan, al menos en sus aspectos técnicos. Sin embargo, pensar ambas artes como independientes es tarea casi imposible en la obra de Bécquer, pues ambas se encuentran firmemente hermanadas.

Por otro lado, la idea de las artes hermanas tiene sus orígenes en estas correspondencias entre imágenes y palabras, y se encuentra firmemente arraigada, desde antiguo, en la tradición ecfrástica. En Mnemosyne, "The Pararell Between Literature and the Visual Arts", el crítico Mario Praz manifiesta lo siguiente sobre este aspecto:

[T]he idea of the sister arts has been so rooted in men's minds since times of remote antiquity, that there must be in it something deeper than an idle speculation, something tantalizing and refusing to be lightly dismissed, like all problems of origins. One might say that by 
probing into those mysterious relationships men think to come closer to the whole phenomenon of artistic inspiration. (3)

Si volvemos a las fuentes clásicas, tendremos que en el canto XVIII de la Ilíada, Tetis suplica a Efesto, el herrero de los dioses, que forje una armadura y un escudo para su hijo Aquiles. En los versos 478-608, se describen en forma detallada las escenas cinceladas en el escudo, un microcosmos de la vida cotidiana en tiempos de Homero. La descripción del escudo de Aquiles, punto de partida de muchos estudios sobre el tema, constituye la écfrasis más antigua conocida. En ésta y en otras definiciones se acentúa la acción de "describir" como acto de recreación plástica.

Dentro de otras definiciones de écfrasis, no muy distantes de las que hemos referido, cabe mencionar la de James Heffernan, que la define como "the verbal representation of visual representation" (Museum of Words). ${ }^{3}$ En términos similares se manifiesta Umberto Eco: "when a verbal text describes a visual work of art, the Classic tradition talks about ekphrasis" (Mouse or Rat 110). El hispanista Leo Spitzer, en su artículo "The Ode on a Grecian Urn, or Content vs. Metagrammar", define la écfrasis como "the poetic description of a pictorial or sculptural work of art" (203). Luz Aurora Pimentel, por otro lado, la determina como una "decripción extendida, detallada, vívida, que permitía presentar el objeto ante los ojos" (Polígrafías 4 205). Claus Clüver, por otro lado, la detalla como "The verbal representation of a real or fictitious text composed in a non-verbal sign system" (“On Intersemiotic Transposition" 13). Años después, la redefine así: "the verbalization of real or fictitious texts composed in non-verbal sign systems" 
(“Quotation” 19). Ernst-Peter Schneck manifiesta, además, que en estas relaciones se produce la "traducción de un modo de experiencia a otro modo de experiencia" (54); es decir, la traducción de ciertos efectos e impresiones de un medio, el visual, a otro, el verbal. Mary Ann Caws se refiere a las descripciones ecfrásticas como "interartistic translations" (3) por su función de transferir "ideas and forms" (3).

Sin embargo, Jean H. Hagstrum, uno de los primeros en retomar el término en The Sister Arts, limita el uso de la écfrasis a la poesía, que le otorga "voice and language to the otherwise mute art objects" (18). Emilie L. Bergmann, por otra parte, concluye en su estudio Art Inscribed: Essays on Ekphrasis in Spanish Golden Age Poetry: "when poets praise painting, it is poetry that is ultimately flattered. When they treat the problems of art and nature in painting, it is the imitation in art in general that they are questioning and, in addition, the peculiar problems of poetic imitation of visual arts. Ekphrasis, thereby gives poetry a new perspective on linguistic creation" (311). Bergmann argumenta, además, que la naturaleza de la écfrasis es: "to trascend the bounderies of a linear, temporal art and to use literature's limitations as a pretext for poetic 'ingenio'" (312). Margaret H. Persin, en su artículo, "The Ekphrastic Principle in the Poetry of Manuel Machado", señala que tanto Bergmann como Krieger se refieren al hecho siguiente:

[E]kphrasis permits a work of literature to convert the static into the temporal, the simultaneous into the chronological, the linear into the circular. Significantly, this particular type of literary description also has the power to throw light not only upon the concrete work of art, but also upon itself, and the mechanisms of its creative process. (2) 
Persin se refiere a los conceptos de artes espaciales y artes temporales, aspectos que han sido esgrimidos como características diferenciadoras por otros tratadistas, Lessing entre ellos, pero que Persin deja aclarados al sugerir el intercambio posible de estos conceptos mediante la écfrasis.

En su obra Getting the Picture, Persin afirma lo siguiente:

The definition of ekphrasis that I utilize... is broadly based, borrows from, and is dependent upon previously debated conceptual parameters. I therefore term as ekphrastic a poetic text that makes reference to a visual work of art, whether real or imagined, canonized or uncanonized, and thus allows that art object, in truth the object of (artistic) desire to 'speak for itself' within the problematically ruptured framework of the poetic text. This art object's ability to speak for itself is dependent upon the intertextual status of its problematic presence in the verbal text. (17-18)

Esta definición de Persin no se aleja, como ella misma afirma, de las definiciones tradicionales o de nuevo cuño. Las referencias a la écfrasis de Diane Chaffee, en "Visual Art and Literature: The Role of Time and Space in Ekphrastic Tradition"; de John Hollander, en "The Poetic of Ekphrasis"; de Michael Davidson, en "Ekphrasis and the Postmodern Painter Poem"; de George Kurman, "Ekphrasis in Epic Poetry", entre otros, no difieren, en síntesis, de todas las definiciones aludidas.

En todos los casos anteriores se acentúa el carácter "dependiente" del texto verbal con relación al objeto visual, lo que permite extender el texto a una relación "intersemiótica", y puesto que el texto verbal (re)interpreta al objeto visual (texto 
no verbal), es decir, lo "lee", la relación se torna, entonces, de carácter "intertextual”. En cualquier caso, nos referiremos a la "intertextualidad", ya sea tomando los planteamientos de Julia Kristeva, de Jonathan Culler, o de Harold Bloom, para designar las relaciones entre texto y texto; y a "interdiscursividad" o "intermedialidad" para las relaciones entre lenguajes verbales y no verbales, es decir para designar "las relaciones que cualquier texto mantiene con todos los discursos registrados en la correspondiente cultura y ordenados ideológicamente" (Marchese y Foradellas 218). Más claramente, nos referiremos a la visión de Cesare Segre sobre la "interdisciplinaridad" y las relaciones entre pintura y literatura.

El concepto de écfrasis, como descripción de una obra de arte visual por medio de una creación verbal o textual, en el sentido que le otorga Heffernan, es una interpretación moderna, que la coloca dentro del campo actual de la interdiscursividad o intermedialidad. En ese sentido, como señala Krieger, "la ambición ecfrástica le otorga al arte del lenguaje la extraordinaria tarea de representar lo literalmente irrepresentable" (Literatura y pintura 142). Para Michel Rifaterre, sin embargo, la écfrasis es siempre una "versión más eficaz" (215) de la imagen original; "su superlativo" (215), afirma, y por lo tanto, difiere de la traducción, entendida como equivalente de la misma. Con todo, la noción de traducción supone siempre el desplazamiento del original y, como resultado, lo que se ha traducido alcanza una existencia propia, independiente del modelo original. A esto Baudelaire lo llamó "productions visuelles ou verbales créatives" (Écrits sur l'art 115), pues en ellas confluyen múltiples construcciones de percepción y producción, tanto visuales como verbales. Estos modos receptivos y productivos 
actúan de manera integral, creando un objeto artístico que supera las relaciones entre significante y significado.

Por otro lado, en L'Illusion d'Ekphrasis, Rifaterre señala su particular visión de écfrasis:

Entiendo pues écfrasis en el sentido que tiene la palabra para la teoría literaria en la que designa un caso particular de descripción o de relato que dio origen a un género menor cuyos procedimientos son del orden de la mímesis. Como el texto ecfrástico representa con palabras una representación plástica, esta mímesis es doble. Pero también es ilusoria, ya sea porque su objeto es imaginario, o bien porque su descripción tan sólo hace visible una interpretación dictada menos por el objeto real o ficticio que por su función en un contexto literario". (Monegal 161)

Rifaterre distingue dos tipos de écfrasis: la crítica y la literaria: "La écfrasis crítica se refiere a un cuadro existente, y sólo tiene sentido si está basada en el análisis formal de su objeto, mientras que la écfrasis literaria presupone el cuadro, sea éste real o ficticio" (162). Podemos deducir de estas definiciones que la écfrasis literaria --más imaginativa que analítica-- se apoya en una (re)interpretación del cuadro, en una imagen creada por el artista; apoyada en objetos visuales reales o imaginarios --materiales o inmateriales-- intermedializados en la narración. Rifaterre argumenta, además, que "en lugar de copiar el cuadro transcribiendo en palabras el dibujo y los colores del pintor, la écfrasis [literaria] lo impregna y lo tiñe con una proyección del escritor --o más del texto escrito sobre el texto visual" (174). 
Para Rifaterre, en este acto "no hay imitación, sino intertextualidad, interpretación del texto del pintor y del intertexto del escritor" (174).

Luz Aurora Pimentel, por otro lado, se refiere a la existencia de tres clases de écfrasis: la "referencial", que es aquélla donde el objeto plástico o visual existe en la realidad; la "nocional", en la cual el objeto visual sólo existe en el lenguaje. A la tercera écfrasis la llama "écfrasis referencial genética", y es aquélla en la que, sin designar objetos precisos, remite al estilo de un artista, su personalidad, trascendencia de su obra, entre otros rasgos definitorios. Como es de carácter atributivo, pues se refiere a la similitud con las características de determinado artista, podríamos también llamarla "écfrasis atributiva o imperfecta". En todo caso, se trata, también, de una écfrasis (re)construida parcialmente a partir de ciertos elementos referidos a un artista, y en ese sentido se acerca a la "écfrasis literaria" de Rifaterre. Las connotaciones interpretativas, parciales y (re)constructivas están asociadas a este tipo de écfrasis. Ésta es, generalmente, la écfrasis elaborada por Bécquer, aunque también acude, por momentos --pero sólo por momentos--, a la écfrasis referencial, como es el caso de las inmaculadas de Murillo, aunque siempre las pinceladas personales de que se vale terminan por alejar sus écfrasis de toda concreción posible, esto es, de toda referencia concreta a una obra existente.

Por su parte, Valerie Robillard establece una división en tres grupos, dependiendo de la mayor o menor intertextualidad: En primer lugar, destaca "la écfrasis descriptiva, que implica la descripción explícita de la obra de arte, se acerca al requerimiento crítico de "representación' de sus fuentes pictóricas (similitud tanto temática como estructural)" (39). Luego, en un segundo lugar, señala la 
categoría "de écfrasis atributiva, donde se indican las fuentes, ya sea mencionando el título, aludiendo al autor, estilo o género" (39), o bien las llamadas por la autora "marcas indeterminadas" que señalan la presencia de un intertexto. La tercera categoría se refiere a la écfrasis asociativa, la cual "se ocupa de poemas que hacen referencia a convenciones o ideas relacionadas con las artes plásticas, ya sean de tipo estructural, temático o teórico" (39). En síntesis, muy cerca de los postulados de Luz Aurora Pimentel.

\section{I.2. La écfrasis becqueriana}

Creo importante precisar lo que debemos entender por écfrasis becqueriana, así como los aspectos que se pueden atribuir al principio ecfrástico en las Leyendas. En primer lugar, de forma más restringida y estricta, utilizaré el término para referirme al intento de Bécquer de imitar con palabras, un objeto de las artes plásticas, esto es, la descripción de "una obra de arte existente", pero no referida de forma concreta en sus relatos. Aquí cabe la definición de Spitzer, pero aún más la que ayudó a fijar Filóstrato al exponer que "poetas y pintores contribuyen por igual a nuestro conocimiento de las gestas y del aspecto de los héroes" (Imágenes, 223). Muchos de los cuadros descriptivos de Bécquer nos remiten a obras conocidas de destacados pintores barrocos, románticos, prerrafaelistas o costumbristas, entre otros, aunque, insisto, no hay referencias a obras determinadas.

En segundo lugar, ampliaremos el concepto de écfrasis, para utilizarlo como "el equivalente en palabras" de una imagen visual, tal y como lo define Hefferman, aunque la voz narrativa declare por momentos la insuficiencia de la palabra para acometer la descripción ecfrástica del objeto visual, del "cuadro". Tomemos como 
ejemplo la descripción del mercado de Tarazona, en la que Bécquer alude a "realidades", "más para vistas que para trasladadas al lienzo" (412), aun cuando sea "un pintor consumado" (412) el que lo intente. Por lo tanto, estamos ante la descripción de un "cuadro inexistente" en términos físicos, de un "cuadro inmaterial"; se trata, en síntesis, de la écfrasis literaria definida por Rifaterre. El referente de esta écfrasis es una impresión visual que, no obstante la aclaración de Bécquer de la imposibilidad de describirla con su pluma, "tan pobre, tan insuficiente" (412), termina describiéndola "verbalmente" como un "cuadro a la vista", pero lo describe, sin embargo, en términos pictóricos, como si estuviese interpretando, de forma simultánea un cuadro existente. De acuerdo con Luz Aurora Pimentel, "la descripción de un objeto plástico en general tiende a anunciarse como tal y pretende ser su equivalente verbal. En esta fase de la construcción verbal, la écfrasis parte de su origen descriptivo para establecer una relación analógicoreferencial con el objeto a representar" (285).

Por otro lado, García Viñó señala que "Bécquer intuía sin duda, en estos momentos, el problema de la diferencia que hay entre los modos de existencia física de las distintas artes y echaba de menos para las temporales la clase de presencia total que pertenece naturalmente a la pintura [a las artes espaciales]" (154).

Refuto este argumento de García Viñó por cuanto, según él, Bécquer "intuía" la diferencia existente entre las artes espaciales y las palabras; pero, nos preguntamos, ¿podríamos hablar de "intuición” en el caso de un pintor-poeta formado artísticamente en los talleres de dibujo y pintura de Cabral Bejarano y de Joaquín Domínguez Bécquer, respectivamente? ¿De alguien que mantenía un 
contacto directo con otros pintores andaluces del círculo sevillano del "tío" Joaquín, heredero de la clientela de su padre, el malogrado artista José Bécquer? ¿Intuición, insisto, en la presencia casi constante en la vida de Bécquer --más bien "omnipresencia"-- de su hermano Valeriano, con el que desarrolla importantes actividades multidisciplinares de pintura y escritura, además del normal intercambio de ideas e impresiones entre dos hermanos, uno, pintor, el otro, pintorpoeta? Podríamos deducir, al contrario, que Bécquer era consciente de la importancia de la imagen y, por lo tanto, la privilegiaba como complemento imprescindible de la palabra; sabedor, en función de sus vastos conocimientos teóricos y prácticos de pintura, de que potenciar una prosa poético-plástica, propiciando un incremento icónico en la misma, fijando imágenes en función del texto narrativo, e impregnándole un dinamismo pictórico a lo representado, al otorgarle valoraciones plásticas, podía añadir al texto nuevas dimensiones enriquecedoras.

Bécquer, creo necesario insistir en ello, no quiso olvidar su condición de pintor, forjada a lo largo de sus primeros dieciocho años de vida en su Sevilla natal, y enriquecida, ya una vez establecido en Madrid, por las visitas a museos y monumentos, así como por el contacto con otros pintores, entre los que incluimos a Valeriano y a Casado de Alisal, y por los frecuentes viajes que realizó a otras regiones para tomar apuntes gráficos, esto es, bocetos artísticos. La comparación con lo visual le sirve, entonces, si no para mostrar la superioridad de la pintura como medio de expresión, comunicación y exaltación de los sentimientos más íntimos --aunque por momentos sí lo hace-- al menos para demostrar que allí donde 
las palabras "resultan inútiles tantas veces" (ㅇras completas 467), la pintura viene a complementar lo que la literatura por sí misma no puede expresar completamente. Así, el doble impulso creador de Bécquer, como narrador y pintor; el furor animi del artista, un concepto platónico puesto de relieve por Leon B. Alberti en $\underline{\text { On }}$ painting (De Pictura), durante el Renacimiento, acusa en nuestro autor características muy específicas, precisamente por esa doble capacidad de Bécquer para narrar y "pintar" de forma secuencial, en el mismo espacio literario.

Por otro lado, esa doble lectura de la referencia visual y de la descripción verbal por parte del lector-espectador --una suerte de confrontación que éste debe hacer ante los dos textos a la vista-- no es un mero acto de acercamiento de semejanzas, ni siquiera una interpretación de descripciones y detalles excesivos, como si de la búsqueda de una energeia, a la manera de los antiguos, se tratara. Antes bien, si toda lectura de un texto visual --y aquí entramos a redefinir el concepto de texto-- es transformable en un texto verbal, habrá tantos textos visuales como miradas se dirijan a él, con lo cual las lecturas del texto visual se proyectan ad infinitum. Pero hay algo más, al describir, como acto de "escribir a partir de", Bécquer selecciona, reorganiza, equilibra, interpreta, "(re)significa” los elementos del texto-cuadro, de la misma manera que lo hace el lector, siguiendo los mismos parámetros del narrador, en función de otras circunstancias.

En tercer lugar, si se amplía el principio ecfrástico hasta su sentido más general, lo podríamos "ver" funcionando en cualquier intento que trate de hacer de la écfrasis un objeto total, es decir, el equivalente verbal de un objeto visual. En este último caso, hablamos de una síntesis representacional de los dos objetos, el verbal 
y el visual. Aquí cabe, entre otras definiciones de écfrasis, la de Claus Clüver. El paisaje de algunas leyendas, o algunas escenas descriptivas que recrean un mundo palpitante y vivo, a veces siguiendo la estructura de agrupar varios cuadros, o de colocar pequeños cuadros dentro de un gran lienzo, ejemplos a los que nos referiremos en los capítulos subsiguientes, apelan a esta descripción ecfrástica, donde sentimos las atmósferas, en una suerte de fusión imagen-texto, más que verlas o leerlas.

\section{I.3. Mímesis, ilusión, impresión y/e (re)interpretación}

En las tres interpretaciones mencionadas, la écfrasis designa un caso de descripción del orden de la mímesis, dentro del sentido de (re)presentar al "otro" no verbal. Además, como el texto ecfrástico traduce a palabras una representación plástica, esta mímesis es doble. Es lo que en el lenguaje platónico se define como "imitación de la imitación". Empero, esta mímesis es "ilusoria", porque su descripción tan sólo hace "visible"--hace "ver"-- al lector una "ilusión" de la realidad. En ese sentido, estaríamos más cerca de una ilusión referencial que de una auténtica representación de un objeto visual, por lo cual el "principio ecfrástico" podría entenderse, además; y ésta sería una cuarta posibilidad de interpretación, como "toda posible lectura" del objeto visual por parte del lector.

El utilizar el término "ilusión" es revelador, porque sitúa el problema en el terreno del "simulacro" y lo vincula a aquella facultad en que lo literario y lo visual se funden: la imaginación. No se trata de si es posible trasladar unos determinados contenidos de un medio artístico a otro. Lo que de hecho está en juego, en palabras de Rifaterre, es "un proceso de diálogo intertextual que da lugar a la 'imitación' 
fingida, dedicado a evocar en la imaginación del lector o espectador la presencia de lo que está ausente" (129), como hace el arte al (re)presentar la realidad o al imitar a la naturaleza, siguiendo el razonamiento aristotélico. En este contexto, afirma Sarduy, "el que copia, primera forma de mimetismo, reproduce, del modelo, las proporciones exactas y reviste cada parte del color adecuado" (17). Si al copiar, sin embargo, se alteran las proporciones del modelo original, lo que se hace ya no es una copia, pues todo intento de reformar o adaptar el original, no hace otra cosa que dar la ilusión del modelo: se trata, en palabras de Sarduy, del "simulacro"; y para éste, "los simulacros, 'a lo que pretenden, al objeto, la calidad, etc., pretenden por debajo, bajo cuerda, utilizando una agresión, una insinuación, una subversión'” (18). Podemos, también, analizar las descripciones ecfrásticas de las Leyendas bajo esta óptica, pues Bécquer adapta, reforma, subvierte el modelo original, lo rediseña, en síntesis. Por lo tanto, si toda imitación es imperfecta y, por lo tanto, resulta en un "simulacro"; piénsese en el trampantojo o trompe l'oeil, en ese "hacer que el ojo se equivoque", que crea "ver" lo que "no es", engañándolo, escamoteándole la realidad, presentándole, en fin, una ilusión de la misma, entonces, ¿no será también la écfrasis, en este caso, una "simulación de la simulación", para seguir en la línea del pensamiento platónico? Porque muchas de las descripciones ecfrásticas en las Leyendas se nos aparecen como fotogramas o cuadros "impresionistas"--en su sentido pictórico de captar una impresión-- de un conjunto, pero se presentan "por debajo", "travestidos", para darnos sólo una idea del conjunto, "una insinuación", "un efecto". Sarduy subraya que "[m]ás que aparentados a la esencia del modelo, y a su reconstitución puntual, respetuosa, los fenómenos a los que nos interesamos... 
parecen empecinados en la producción de su 'efecto'" (18), tal y como buscaban los pintores impresionistas.

Al emprender la lectura de las Leyendas de Bécquer, lo primero que nos salta a la vista es el estilo de Bécquer, surgido de su profunda voluntad artística. Para Berenguer Carisomo, el de Bécquer “es el primer estilo 'artístico' que se presenta en la prosa de la España del siglo XIX" (42), aunque, por otro lado, este tipo de prosa está presente en obras de escritores extranjeros, como Chateaubriand, Gautier y Mérimée, entre otros, que, de alguna forma, comparten con Bécquer ideales estéticos. En ese sentido, las imágenes que Bécquer nos presenta, a veces de forma secuencial, la riqueza de su adjetivación, así como el estilo, en que nos presenta estas imágenes, "ese inmenso botín de impresiones, de pequeños detalles, de joyas extraviadas, de trajes pintorescos, de costumbres características animadas y revestidas de esa vida que presta a cuanto toca una pluma inteligente o un lápiz diestro" ( Obras completas 411); o esa "extraña armonía de la forma, el color y el sonido" (Obras completas 413), como Bécquer las llama, parecen generar reflejos coloridos y sonidos disímiles, mientras las leemos; hasta tal punto se manifiestan de forma sensorial. García Viñó también señala "que la repetición pretendía acercarse lo más posible a la simultaneidad en la evocación. Y era el efecto de este intento a lo que llamaba seguramente 'pintar con palabras'” (155).

Asimismo, los "mil y mil accidentes pintorescos que a la vez cautivan el ánimo y llaman la vista como reclamando la prioridad de la descripción" (마as completas 414), que Bécquer arroja "a granel sobre las cuartillas" (아as completas 414), como metáforas del lienzo, como él mismo destaca en Desde mi celda, nos 
hablan de Bécquer como un indiscutible precursor del movimiento pictórico impresionista --no me aventuro a hablar de una prosa impresionista--, "pues en vez de un detallismo descriptivo, notarial, lo que nos proporciona son brochazos sintéticos de los colores, los objetos, los movimientos" (Villanueva 59). Para Edmund L. King, "the term [impressionism] belongs to painting, to the kind of painting that seeks to reproduce on canvas the impressions of light of the retina of the painter's eye. Mind, memory, emotion have no place in impressionist painting" (43). Sin embargo, Bécquer nos transmite una "impresión" de la experiencia visual, y ésta es, además de plástica, sumamente emotiva. En eso, indudablemente, se aleja del concepto clásico de impresionista.

Así, tenemos que en esta impresión, por momentos, se conjugan los colores y la luz en un juego pictórico de gran plasticidad: "los mil y mil accidentes... que llaman la vista" nos remiten a Monet, Pizarro, Renoir, entre otros pintores impresionistas. Pero, además, Bécquer apela al lector, en tanto que demiurgo platónico, para que éste organice el "caos" de su creación plástica y pueda (re)construir a su antojo el universo del cuadro. Es decir, decide compartir con el lector la creación de la construcción ecfrástica:

[C]onfundidos y entremezclados en mi memoria con el recuerdo de la monumental fachada... con sus figuras colosales de granito, sus frisos por donde se extiende una larga y muda procesión de guerreros... forman en mi cabeza un caos tan difícil de desembrollar en este momento, que si ustedes con su imaginación no hacen luz y lo ordenan y lo colocan a su gusto..., las figuras de mi cuadro se 
quedarán sin fondo, los actores de mi comedia se agitarán en un escenario sin decoración ni acompañamiento. (아as completas 414)

En este sentido, Bécquer le confiere al lector un poder de acción y una capacidad de participación en la lectura y (re)construcción del cuadro inmaterial; lo transforma, en definitiva, en lector activo, en destinatario, de acuerdo con la definición de Jakobson, que son rasgos de una modernidad sorprendente. Resulta sintomático, por otro lado, que el caos sólo afecte al fondo del cuadro, la “decoración”, es decir, al paisaje y no a los personajes que en él se mueven. De nuevo, el entorno, el paisaje, la atmósfera del cuadro, en definitiva, como elemento definitorio de la actuación de los personajes, ocupa el interés principal de Bécquer.

En relación con las Leyendas, resulta imprescindible ampliar el análisis lingüístico sobre las imágenes y los modelos visuales que constituyen sus referentes, a su necesaria extensión imaginaria. En ellas, el texto se define no sólo como material verbal, esto es, como material comunicativo-lingüístico, sino que a partir de sus especificidades como texto icono-verbal, termina por expresar y comunicar todo un universo imaginativo. Esta es una peculiaridad de la écfrasis becqueriana, lo que la hace particularmente distinta y original. Lo más importante es la experiencia visual que nos transmite, esto es, su capacidad para comunicarnos y para hacernos visualizar, sobre todo, la plasticidad de las imágenes; no se trata de una mera descripción verbal de la misma.

Bécquer, debo insistir en ello, tiene la mirada propia del artista que traduce lo que ve, pero desde su peculiar forma interpretativa. Por lo tanto, la (re)creación artística de Bécquer, la representación textual de lo visual, anula, hasta cierto punto, 
la fuente original; es decir, podríamos hablar de "traducción interpretada" dentro de la visión crítica que contempla su resultado como una "creación" nueva, distinta. Por otro lado, todos los estudiosos de la écfrasis, desde Hermógenes hasta Hefferman, concuerdan en señalar el carácter representacional de la misma, pues de alguna manera representa --vuelve a presentar-- el objeto visual ante el lector-espectador. Tampoco podemos obviar, su carácter interpretativo, ya que en el acto mismo de "mirar", y luego "describir", hay implícito un proceso de selección, jerarquización y reorganización del material visual que reinterpreta y (re)significa el objeto plástico.

Para el filósofo Étienne Souriau, desde una perspectiva comparativa, "las correspondencias inter-artísticas son muy semejantes a una traducción" (16). En definitiva, podemos afirmar que las artes siempre han colaborado entre sí --o se imitan entre sí, siguiendo el principio aristotélico de que todas las artes son el resultado de la imitación-- al retomarse unas de otras los grandes hitos, temas, personajes, ambientes, o momentos míticos o heroicos que se deseaban plasmar, ya fuese a través de la pintura, la escultura, la música, la arquitectura, la danza, las artes decorativas, el grabado, o la propia literatura en todas sus manifestaciones.

Primeramente, la "traducción" pictórica o visual de Bécquer puede entenderse como una "traducción interpretada" de la obra artística o de un objeto visual en general, que realiza el artista (Bécquer); traducción que puede tener un referente material o inmaterial. En segundo lugar, como una "traducción" que es la "reinterpretación" o "recreación" que lleva a cabo el artista (Bécquer) del objeto visual o "cuadro", pero "intermedializado" por el narrador (el propio Bécquer). Por último, la podríamos entender como una "traducción" que se apoya en préstamos y 
coincidencias, en cuyo caso estaríamos tratando las relaciones externas y, por consiguiente, estaríamos ante una visión comparatista.

Las alusiones a la insuficiencia del lenguaje para describir imágenes o traducir las sensaciones que éstas suscitan en el espectador, abundan en la obra narrativa de Bécquer, a manera de recurso discursivo, pero al igual que hace Denis Diderot en sus Salons, en los que publicaba sus críticas de arte, y en los que la ausencia de reproducciones visuales de las obras que comentaba lo obligaba a recurrir a descripciones pictóricas de gran plasticidad, Bécquer se propone compensar esas "insuficiencias" de la palabra con descripciones plástico-narrativas, esto es, con descripciones ecfrásticas. Por lo tanto, a pesar de la distancia que pueda haber, el elemento plástico está presente para provocar la descripción y narración literarias.

La aparente paradoja de utilizar palabras para describir imágenes, cuando aquéllas resultan insuficientes, no sólo nos remite a la naturaleza de la écfrasis como texto-imagen o imagen-texto --dependiendo de la prioridad que le acordemos y si aceptamos la posibilidad de intercambio de uno y otro objeto-- sino, además, a su condición de texto autónomo; esto es, como un "otro extra-textual" en relación con el discurso que intenta representarlo y que pasa, incluso, a ocupar un primer plano. A ese "otro extra-textual" lo llamaremos "icono-texto", en el sentido que le otorgaremos en este trabajo. En realidad, Bécquer construye "otro relato", y ese otro relato es, de acuerdo con Rifaterre, "más afín al texto que lo rodea que a su referente y que, sin embargo, no deja de remitir a ese objeto que desencadena la actividad descriptiva: ese otro que puede reconocerse como tal" (168). 
¿Qué sucede, entonces, cuando el intérprete-narrador y el pintor son la misma persona, como es el caso de Bécquer; cuando la interpretación del objeto visual y la narración se realizan desde una perspectiva única, aun cuando el narrador-pintor esté llamado, por otro lado, a interpretar la obra de otros pintores? Como el acto interpretativo precede a la representación visual, y ésta, por fuerza, tiene que ser "traducida" a signos verbales, puesto que la representación no puede insertarse plásticamente en el texto; es decir, no puede representarse a sí misma, tenemos que la interpretación del objeto visual se produce, primeramente, por la capacidad del artista para "mirar" y "traducir" el objeto visual, pero la visualidad descrita, en tanto que objeto verbal, la hace el narrador. En uno y otro caso, suele ser muy difícil, si no imposible, separar al Bécquer artista del Bécquer narrador, o a éste de aquél.

Por otra parte, el lector-espectador, durante la lectura de las Leyendas, se fusiona con el narrador-pintor al introducirse en el mundo que éste propone, al participar de la visualidad descrita, al compartir una visión única. El texto, la representación visual como tal, nos ofrece la mirada del artista y su interpretación de la imagen, y lo hace mostrándonosla, pues Bécquer nos hace "ver" una construcción visual, un punto de vista, pero sin absorber con su mirada nuestra capacidad de utilizar la nuestra. Así, en los "cuadros" que nos presenta Bécquer, se hallan algunos de los elementos típicos --y tópicos-- del Romanticismo, pero vistos desde una óptica plástica: las ruinas, los monumentos, los castillos, las iglesias góticas, y hasta los paisajes son, sobre todo, elementos esencialmente pictóricos del cuadro descriptivo, pero están más cerca de la obra pictórica de Claude Lorrain, de Rembrandt, de Murillo, de Corot, de Gaspar David Friedrich, de Mariano Fortuny o 
de Eugène Délacroix, entre otros artistas, que de los escritores románticos y posrománticos. Bécquer transforma estos valores icónicos en elementos compositivos del cuadro, dentro de la elaboración de un conjunto visual que nos "dice", pero "mostrándonos", sin dejar de traslucir, por otra parte, sus valores léxicocomunicativos como texto poético-narrativo. La descripción del entorno se convierte, entonces, en una pintura simbólica esencial para situar al lector en la atmósfera de la leyenda, así como para proveerle de los elementos plásticos más característicos de los protagonistas. En ese sentido, estaríamos refiriéndonos a una semántica de las imágenes. Al respecto, Diego Lizarazo ha manifestado que "la semántica de las imágenes apela al contexto, a los usos, a lo simbólico, y no sólo a las categorías y taxonomías de tipo estructural o lógico. Es probable que dos sean las razones principales de esta rebeldía del sentido visual: la plasticidad de la imagen y el régimen de lo imaginario" (9).

En cuanto a la primera de estas razones, Lizarazo agrega que "[l]a razón primera se refiere, en síntesis, a que la imagen no puede decir sin mostrar; toda referencia icónica es también una elaboración plástica, porque su modalidad del decir es el color, el trazo, la forma" (9). Podemos afirmar, por tanto, que la denotación icónica es intrínsecamente estética; no se manifiesta sólo para expresar un concepto, sino para producir en el destinatario, en su doble papel de lector-espectador, una experiencia sensorial. Además, de acuerdo con otra afirmación del propio Lizarazo que viene a reafirmar lo anterior, "la imagen convoca una semántica más vasta en la que hay un corrimiento continuo entre lo argumental y lo poético, lo real y lo onírico. Un corrimiento del sentido por el orden de una elaboración múltiple del 
espacio (simbólico, referencial, pictórico, plástico) para la mirada, en la que comienza y encuentra su término" (10).

La segunda razón procede del orden de lo imaginario, por lo tanto, se produce en la estrecha relación entre la imagen y la mirada. En ese sentido, afirma que "la mirada resulta formada por la imagen tanto como la significación de la imagen se debe, de trazo a trazo, al horizonte visual desde el cual se mira. Por eso la imagen aflora un régimen y un cosmos de miradas que convocan una multiplicidad de problemáticas" (10). Éstas se refieren, fundamentalmente, a la relación entre percepción referencial y percepción icónica; al mundo de las miradas, resumido en la interesante cuestión de que el mundo que miramos es el mundo que también nos ve; del problema de las fronteras o de los límites de la mirada.

Ese paisaje visual de Bécquer, al que hemos estado refiriéndonos, podría inscribirse, además, en lo que Kenneth Clark llamó paisaje de "fantasía" e "imaginario", apoyado en ciertos modelos visuales románticos, prerrafaelistas, costumbristas, entre otros. En términos transversales, las Leyendas abordan nociones relacionadas con la fantasía, la mirada, la iconicidad y la imaginación; todo un tejido de carácter semántico que implica una suerte de hermenéutica de la imagen que integra diferentes recursos como la imaginación, la visualización y la iconización, dentro de un contexto poético-narrativo-plástico. Estos recursos aparecen insertados por medio del "cuadro" descriptivo, interdiscursivo y polisémico, pero también abierto a una multiplicidad de abordajes.

Sobre esta forma de Bécquer de interpretar el paisaje, el propio Leonardo da Vinci, partiendo de Horacio, considera la pintura como una especie de género 
poético, de acuerdo con la clásica alusión --devenida tópico-- al concepto de $U t$ pictura poesis, y a la pintura de paisajes, dentro de una lírica pastoral, de lo cual podemos deducir que para Da Vinci existe en ella para una considerable carga estético-emocional.

Por otra parte, en el "Parangón" del Tratado de la pintura, Da Vinci nos dice que "el pintor hará infinidad de cosas que las palabras ni siquiera pueden nombrar, por no existir para aquéllas los vocablos apropiados" (18 Urb. 1a y 1b, 47). En otro apartado del mismo "Parangón", Da Vinci enfatiza que "la poesía dispone sus asuntos en signos imaginarios, en tanto que los de la pintura exceden al ojo, el cual recibe sus imágenes no de otra suerte que si fueran reales; la poesía, por el contrario, ignora el simulacro de las cosas, que no alcanzan, así, la conciencia a través del órgano visivo, como ocurre en el caso de la pintura" (17 Urb. 1b, 45-46). Esta visión de da Vinci no hace más que confirmar la propia idea de Bécquer sobre la supremacía de la pintura sobre la poesía, en cuanto a la capacidad de aquélla para expresar lo que las palabras no alcanzan a hacer, tal y como manifiesta en múltiples textos.

\section{I.4. La pintura como ejercicio preliminar de las "Leyendas"}

Si nos atenemos a lo que cuentan los primeros biógrafos de Bécquer, esto es, los que lo conocieron íntimamente, "al tiempo en que Valeriano le ilustraba algunos de sus poemas, Gustavo Adolfo componía textos de acento lírico para determinados dibujos de su hermano" (Battistessa 36). Esta colaboración se acentuaría mucho más con los años, sobre todo durante la etapa en que ambos colaboraron en El Museo Universal. 
Según relata Rica Brown en su biografía de Bécquer, don Leopoldo Augusto del Cueto quería hacer representar en su biblioteca una serie de escenas de las obras de los más importantes dramaturgos. A Valeriano Bécquer le encargó las del teatro inglés, entre otras. "Para dar una idea del genio de mi hermano" (79), le contó Bécquer a José Castro y Serrano, "voy a referir lo que pasó" (79):

Una de las obras a que daba más prisa era la representación de Ofelia. Mi hermano corrió a verme y me dijo: ¿Quién es Ofelia? Yo entonces tomé la pluma, como acostumbraba en casos semejantes, porque él me dibujaba mis versos y yo le versificaba sus cuadros, tomé la pluma y dije:

Como la brisa que la sangre orea sobre el oscuro campo de batalla, cargada de perfumes y armonías en el silencio de la noche vaga; símbolo del dolor y la ternura del bardo inglés en el horrible drama, la dulce Ofelia, la razón perdida, cogiendo flores y cantando pasa. Valeriano --continuó-- hizo por impregnarse del espíritu de estos versos, lo cual le era familiar; y poco tiempo después Cueto recibía la dulce Ofelia de Shakespeare, como si el autor hubiese tenido dentro del alma las imágenes del gran poeta. Él, sin embargo, no leyó a "Hamlet" sino mucho tiempo más tarde. (79-80) 
El interés de la anécdota es doble: primero porque revela la estrecha colaboración artístico-literaria entre ambos hermanos y el grado de comprensión que existía para adaptarse uno a la obra del otro, y encontrar los mecanismos idóneos para su "traducción". Esto pudo haber sido un ejercicio vital para Bécquer en el sentido de ayudarle a entender los resortes que utilizaba la pintura en relación con la literatura; y segundo, porque la figura de Ofelia parece haber tenido en Bécquer un especial interés. En el "Libro de cuentas" y en otros dibujos ya aparece el tema de Hamlet tratado por Bécquer. Por otra parte, en algunas leyendas, "El rayo de luna” y "La ajorca de oro”, por ejemplo, o en las narraciones, “Es raro!” y “La venta de los gatos", la locura juega un papel fundamental en el desarrollo del tema. La propia Rica Brown destaca que "la figura de Ofelia parece representar para Bécquer la mujer ideal, lánguida y dulce como la armonía celeste, y su locura sugiere el misterioso poder del amor desgraciado" (80). No escapan, por otro lado, otras posibles asociaciones pictóricas con el drama de Shakespeare. Esta fraterna correspondencia entre las creaciones de uno y otro hermano, a la que hemos aludido antes, alcanza niveles de cooperación profesional cuando ambos colaboran en las conocidas páginas de El Museo Universal.

Importa destacar aquí el modo de trabajo de Bécquer, su comportamiento expresivo; en la composición de muchas de sus obras, "el poeta solía 'ayudarse' con el estímulo de imágenes gráficas. En la plana más favorecida: una tumba gótica, la traza de varios personajes, unos perfiles femeninos, este o aquel borrón, y rápidos, dispersos garabatos" (Battistessa 35). También conviene destacar el comentario de Florencio Morino Godino, inicialmente publicado en la "Ilustración Artística", en 
1895, con referencia a la poesía, pero que puede aplicarse igualmente a las Leyendas:

Bécquer dibujaba, antes de escribir, un esbozo de la composición pensada, o cuyo tema estaba pensando y el cual le proporcionaba a veces el dibujo, que delineaba inconscientemente y como al acaso. En una ocasión, sin intención previa, trazó un sepulcro gótico y sobre él la estatua yacente de una mujer; empezó a hacer el cimiento de la ojiva que habría de cubrirle y esto le sugirió la idea de una de sus composiciones poéticas. (Cit. por Batistessa 35)

La cita, sobre todo si se la compara con el propio dibujo, debe tomarse como ejemplo concreto de los recursos expresivos utilizados por Bécquer, en los que se vale de la previa recreación pictórica del tema y de los ambientes y escenas de la trama argumental, lo cual añade una particular dimensión plástica al texto literario. Estos recursos, tras algunas transformaciones, terminarán por definir la prosa pictórica de las Leyendas; esto es, la elaboración de descripciones ecfrásticas, que apelan a lo visual como posibilidad enriquecedora del texto literario, lo que confirma, en buena parte, otras muchas citas dispersas en su obra. El propio "Libro de cuentas" del maestro José Bécquer, que a su muerte fue utilizado por el joven Gustavo Adolfo como soporte de proyectos y preparaciones en prosa y en verso, acompañados de dibujos, es una prueba documental indiscutible de este procedimiento de escribir con la previa o alterna realización de apuntes artísticos.

En el prólogo a la edición de las Obras Completas de Bécquer de Aguilar, así como en el estudio de Rafael Montesinos, Bécquer, biografía e imagen se 
reproducen algunas de sus páginas (111-112), al igual que las de otro álbum: “Los Contrastes o Álbum de la Revolución de julio de 1854" (136-137). Según acota Jesús Rubio Jiménez, este álbum "estaría en propiedad de familiares de Bécquer, pero nunca se han reproducido más que algunas páginas" (299). La obra de Rubio reproduce con mejor acierto gráfico muchos de los dibujos del libro de contabilidad y de los encargos, el llamado "Libro de Cuentas"(290-297), como se le conoce; pero no se trata, desde el punto de vista gráfico, de una obra definitiva en ese sentido, pues como él mismo afirma, está "aún por estudiar" (290).

En "Tres fechas", narración por mucho tiempo incluida en antiguas ediciones de las Leyendas, pero finalmente excluida, precisamente por su carácter probadamente autobiográfico, Bécquer hace referencia, una vez más, a su costumbre de tomar apuntes del natural. Así, declara: "En una cartera de dibujos que conservo aún llena de ligeros apuntes hechos durante algunas de mis excursiones artísticas a la ciudad de Toledo..." ( $\underline{\text { Obras }} \underline{\text { completas }}$ 313). Al avanzar la historia, las referencias se suceden: "Cuando por primera vez fui a Toledo, mientras me ocupé en sacar algunos apuntes de San Juan de los Reyes" (Obras completas 314); o esta otra referencia más precisa, donde el término "apunte" cede el paso a la acción de dibujar, lo que corrobora que no se trata de "apuntes" escritos: "Aquel día me distraje dos o tres veces dibujando" (Obras completas 315). Pero su llegada a la plaza es, sin duda, uno de los ejemplos más concretos de las técnicas descriptivas de Bécquer en la que se aúnan su mirada de artista, su capacidad interpretativa y su poder representacional. Así, muy sorprendido por "la extraña decoración que al penetrar en la plaza" (Obras completas 318) tenía ante sí, Bécquer exclamó, 
refiriéndose a un edifico de franca influencia árabe en su arquitectura y decoración exterior:

-- ¡He aquí lo que yo deseaba encontrar! -- exclamé al verle.

Y sentándome en un pedrusco, colocando la cartera sobre mis rodillas

y afilando un lápiz de madera me apercibí a trazar, aunque ligeramente, sus formas irregulares y estrambóticas para conservar por siempre su recuerdo.

Si yo pudiera pegar aquí con dos obleas el ligerísimo y mal trazado apunte que conservo de aquel sitio, imperfecto y todo como es, me ahorraría un cúmulo de palabras, dando a mis lectores una idea más aproximada de él que todas las descripciones imaginables.

Ya que no puede ser así, trataré de pintarlo del mejor modo posible, a fin de que, leyendo estos renglones, pueda formarse una idea remota, si no de sus infinitos detalles, al menos de la totalidad del conjunto. (Obras completas 318-319)

La cita atestigua, una vez más, el método de trabajo de Bécquer. Primero, los apuntes del natural, esto es, la realización de dibujos como tarea preliminar; en muchos casos insistirá en el carácter de boceto o trazo ligero e inacabado, porque aun así, el apunte "imperfecto y todo como es" no sólo le ahorraría "un cúmulo de palabras" a sus lectores--con lo cual subraya la inutilidad de éstas para expresar la realidad-- sino, además, porque los lectores tendrían "una idea más aproximada" del edificio de la plaza. Es decir, con este argumento subraya la capacidad del dibujo como el medio de expresión más completo para expresar la realidad. Entonces, ante 
la imposibilidad de "pegar" el dibujo, afirma, intentará "pintar" el edifico y la plaza, esto es describirlos plásticamente a partir de construcciones ecfrásticas, a fin de que los lectores lleguen a tener una idea de conjunto, aunque fuera "remota".

Resultaría paradójica esta última afirmación si no conociéramos el modo de trabajo de Bécquer, ya que una lectura de la descripción de la plaza y del edificio que la domina arroja un esmerado "cuadro" de conjunto, que Bécquer nos ha presentado hasta en sus más ínfimos detalles en cuanto a forma, composición y color. Sólo al final, cuando declara: "dejé caer de mis manos el lápiz y abandoné el dibujo" (아as completas 320), porque ya anochecía, es que nos damos cuenta que Bécquer nos estaba "pintando" la escena con palabras.

Estos apuntes artísticos del natural sobre paisajes, edificaciones, ruinas, y hasta de los lugareños que poblaban estos lugares (como ya hemos apuntado) y de los cuales existen pruebas gráficas, terminarán por ambientar sus leyendas, por convertirse en elementos de la composición del "cuadro". Su labor de investigación abarcaba por igual tanto lo escrito, apoyándose en sus notas, como lo pictórico, mediante estos apuntes o bocetos tomados del natural. Al redactar "Tres fechas", declara Robert Pageard, "realizó sin duda Bécquer un antiguo proyecto, materializado por dibujos y apuntes. Pudo vivir, por segunda vez, la aventura artística de la Historia de los templos de España, completando los cuadros líricos de 1858 con algunas páginas del diario poético y con la evocación de la Plaza de Santa Isabel de los Reyes" (327).

Bécquer dibujó en abundancia. Se encuentran dibujos suyos en sus manuscritos, en hojas volantes, en los mencionados álbumes. Tal y como apunta 
Robert Pageard, “[s]u destreza para dibujar los personajes era innata; la enseñanza recibida en los estudios sevillanos desarrollaría esta facultad, orientándola hacia el cuadro de historia y de costumbres. Además, sus maestros le hicieron alcanzar un buen nivel en los campos del dibujo de arquitectura, de parque y de paisaje" (59). En términos muy similares se manifiestan sus amigos Campillo y Rodríguez Correa. El primero, en la biografía de 1871, destaca que Bécquer poseía "extraordinarias dotes" (Cit. por Pageard 59) para el dibujo. Además, en una carta dirigida a Eduardo de la Barra, Campillo emite el siguiente juicio: “En música y en pintura hubiera sido más que en poesía. Dibujaba muy bien" (Cit. por Pageard 59). Este juicio de Campillo, aunque cueste aceptarlo del todo, es válido como prueba de reconocimiento de sus capacidades pictóricas, todavía muy poco valoradas en la actualidad a falta de un estudio de su obra pictórica en particular.

En el prólogo ya mencionado de 1871, Correa señala que Bécquer "había aprendido a dibujar al mismo tiempo que a escribir" (Cit. por Pageard 59). En este prólogo, Correa recrea también una conocida anécdota que recoge Edmund L. King en su obra Gustavo Adolfo Bécquer: from painter to poet, que ilustra no sólo el hábito de dibujar de Bécquer, sino, además, su capacidad para relacionar sus dibujos con la experiencia literaria. Bécquer acababa prácticamente de ingresar en la Dirección de Bienes Nacionales, cuando ocurre lo siguiente:

Tratóse de hacer un arreglo en la oficina y el Director quiso por sí mismo averiguar la idoneidad y el número de los empleados, visitando para ello todos los departamentos. Gustavo, entre minuta y minuta que copiaba, o bien leía alguna escena de Shakespeare, o bien la 
dibujaba con la pluma, y, en el momento en que el Director entró en su negociado, hallábase él entregado a sus lucubraciones. Como sus dibujos eran admirables, ya se habían hecho casos de atención para todos, que se disputaban el poseerlos, aguardando a que los concluyera, mientras seguían con la vista aquella mano segura y firme, que sabía con cuatro rasgos de pluma hacer figuras tan bien acabadas. El Director se unió al grupo, y después de observar atentamente aquel tan raro expediente en una oficina de Bienes Nacionales, preguntó a Gustavo, que seguía dibujando:

-- Y ¿qué es eso?

Gustavo, sin volverse y señalando sus muñecos, respondió:

--Psch... ¡Esta es Ofelia, que va deshojando su corona!

Este tío es un sepulturero... Más allá...

En esto observó Gustavo que todo el mundo se había puesto de pie, y que el silencio era general. Volvió lentamente el rostro y...

--¡Aquí tiene usted uno que sobra!-- exclamó el Director. (14-15)

La anécdota ilustra el hecho, por demás característico, de que Bécquer no abandonó el hábito de ilustrar o acompañar con dibujos las recreaciones literarias, aun cuando éstas no fueran el resultado directo de su creación, como es el caso de esta descripción del personaje de Ofelia, de Shakespeare, que conocía muy bien tanto literaria como plásticamente. Antes bien, Bécquer fue consciente de la capacidad de las imágenes para complementar un texto literario, como prueba, por un lado, el uso de apuntes o bocetos como actividad preliminar a la escritura, y, por 
otro, la incorporación de construcciones ecfrásticas a partir de objetos visuales reales o imaginarios. Estos recursos formaban parte de su vasto caudal artístico, enriquecido por las enseñanzas recibidas en los talleres de pintura sevillanos; así como por su afán de estudiar, documentar y describir las obras de arte --pictóricas, arquitectónicas y escultóricas-- a las que tuvo acceso, bien a través de los libros, de sus investigaciones o de sus innumerables viajes por algunas regiones de España -motivados casi siempre por motivos de salud--; viajes que casi siempre realizaba junto a su hermano Valeriano, lo cual reforzaba su propia perspectiva artística con los aportes de éste.

Las relaciones de Bécquer con el arte, por otro lado, lo hacen recurrir, casi de forma natural, a la analogía con la pintura, para así intentar suplir con la interpretación y representación ecfrástica la insuficiencia e inutilidad de las palabras, tal y como se refleja en la cita que inicia este capítulo y en otras muchas referencias a estos aspectos en su abundante obra en prosa. Como afirma Carolina Corbacho,

[1]as correspondencias entre las artes, entendidas como el conjunto de equivalencias o analogías que los diferentes códigos pueden establecer entre sí, nos revelan un aspecto importante de este campo del saber, porque al poseer un hilo de continuidad en la tradición de la estética --como fórmula alentadora para los creadores y como asunto de interés para los estudiosos-- ponen de manifiesto una vez más el matiz universal de la cultura, que no se desbarata a lo largo de los siglos (ni aun cuando las homologías pasen más desapercibidas). (23) 
La tradición centenaria de la crítica de las "artes hermanas", así como los estudios existentes sobre la literatura y las artes plásticas han sido el modelo "clásico" de aproximación al estudio interdisciplinar de las representaciones verbales y visuales. Es decir, el método "de comparación inter-artística”. Desde el nacimiento de la Poética, Aristóteles compara las diferentes artes, los modos de imitación, y apoya en comparaciones los conceptos fundamentales de su obra, partiendo de la mímesis. De alguna manera, estas comparaciones sientan las bases de la crítica comparatista. En ese sentido, a partir de René Wellek y Austin Warren, se ha venido reafirmando la importancia de la relación entre literatura y artes no verbales. La visión analógica y comparatista con que podemos abordar las Leyendas, no sólo está avalada por la tradición clásica o explicada por la teoría literaria, sino que se halla justificada, además, por el propio hogar paterno. De hecho, la influencia de la imagen pictórico-costumbrista de los Bécquer-pintores y de un numeroso grupo de artistas sevillanos en la escritura de las leyendas becquerianas, al igual que sucede con otras referencias pictóricas que se reflejan en éstas, nos remite a la decisiva influencia de la pintura en la elaboración de estos relatos fantásticos, como ya hemos señalado y analizamos en este trabajo.

Es innegable que existe una filiación entre las obras de estos artistas y los rasgos icónicos de las leyendas. Las conexiones texto-imagen que observamos, sobre todo en estos relatos fantásticos, pero que no están ausentes del resto de su obra poética o narrativa, son el resultado de un proceso referencial, interpretativo y representacional --por cuanto existe un referente material o inmaterial, sujeto a un proceso interpretativo, para luego ser representado-- que va más allá de la écfrasis 
tradicional; es decir, Bécquer no pretende imitar o describir de forma exacta la imagen visual o el cuadro, sino representar algo nuevo y singular --una interpretación y (re)creación pictórica del objeto visual-- que active una nueva manera de significar a partir del diálogo entre distintos medios expresivos.

Bécquer vivió, como lo testimonia su obra, en una búsqueda por "domar el mezquino idioma" (62), como señala en su Rima XI, de convertir las palabras en imágenes que fuesen capaces de "verbalizar" sus impresiones sensoriales; y esto aspira a lograrlo "con palabras que fuesen a un tiempo suspiros y risas, colores y notas" (Rima XI, 62). El Bécquer-pintor, como avalan sus incontables referencias al tema, fue plenamente consciente, desde sus orígenes como escritor, de la insuficiencia o incapacidad de las palabras para expresar lo que la pintura, la escultura, la arquitectura y la música podían hacer con absoluta claridad: la línea, la forma, la composición, la luz, el color, la perspectiva, los tonos, los matices y las sonoridades. Pero el Bécquer-narrador potencia, más bien, las capacidades plásticas y sonoras de las palabras, superando la función denotativa de las mismas. Ese fue el camino escogido por él: la búsqueda --y el acertado hallazgo-- de unos recursos estilísticos que le permitieran "encerrar" en el marco, ya no tan estrecho de las palabras, sus impresiones sensoriales, sin que éstas perdiesen su capacidad de transmitirnos una impresión "vívida" de lo representado.

Así, en ese contexto, Bécquer entendió su labor literaria como el resultado de una fusión de las artes, pero desde una perspectiva muy personal; y en ese sentido nuestro autor se planteó la necesidad de servirse de formas y de técnicas relativas a la artes plásticas y a la música, fundamentalmente, que le permitieron estructurar 
un "texto ecfrástico", capaz de convertir "en palabras" las representaciones "noverbales"; en este caso artísticas, a fin de "superar" los límites inherentes al código lingüístico y construir un modelo artístico-verbal como en las artes figurativas, de acuerdo con el principio icónico. En definitiva, como ha sido debatido y analizado por los críticos, el arte es un medio de comunicación y, por lo tanto, es esencialmente un lenguaje por definición. Como afirma Yuri M. Lotman en Estructura del texto artístico "todo sistema que sirve a los fines de comunicación entre dos o numerosos individuos puede definirse como lenguaje"(1). Siguiendo este razonamiento, la elección por parte de Bécquer de un proyecto artístico como la Historia de los templos de España, antecedente plástico de las Leyendas, no es casual, ya que constituye la expresión de sus prioridades por privilegiar la percepción visual como forma primaria de contacto del lector con el texto literario, lo que añade elementos de mayor complejidad que nos obligan a redefinir el concepto de "texto literario becqueriano" desde otras perspectivas. Talens, Company y Fernández Esteve propusieron una tesis sobre el concepto de texto mucho más abarcadora, que pretende la delimitación epistemológica de la noción de texto como "instrumento operativo no sólo en el campo de las prácticas verbales, sino en el análisis de cualquier tipo de práctica de producción de sentido. Para ello no limitan la noción de texto al campo de lenguajes verbales, sino que la extienden a los lenguajes no-verbales" (Martínez Fernández 27). Por lo tanto, el espacio textual que propongo para una nueva lectura icono-textual de las Leyendas becquerianas es un espacio de confluencias de lenguajes verbales y no-verbales; esto es, un espacio plural donde convergen imágenes, sonoridades y palabras. Esta riqueza en los 
signos icónicos de las Leyendas permite explorar nuevas relaciones e implicaciones de estos signos de origen no-verbal con relación al texto literario en el que aparecen intertextualizados, o todavía mejor, intercalados a manera de interdiscursividades o intermedialidades, términos más apropiados, tal y como hemos señalado. 


\section{NOTAS AL CAPÍTULO I}

${ }^{1}$ De acuerdo con Pageard, "el examen del Armorial general, de Juan Bautista Rietstap, revela que numerosos Becker nobles han existido en los países germánicos, especialmente en Silesia, Sajonia, Prusia, en el Palatinado y en los Países Bajos. Las familias nobles Becker o Bécquer de Holanda, Flandes y Sevilla tienen armas de idéntica estructura" (25)

Casi todos los biógrafos de Bécquer aluden al origen flamenco de sus antepasados, corroborado por Pageard: "Según Rietstap, los Bécquer de Sevilla eran originarios de la provincia de Güeldes" (26), por lo tanto eran de origen flamenco. También, de acuerdo con Pageard, "[e]en la partida de bautismo de Gustavo Adolfo se halla la ortografía Vequer. José Domínguez Bécquer firmaba Bequer, Becker y Beker. A la abuela materna le dan en los registros [...] los apellidos Bequer y Baquer" (31).

2 No hay un consenso sobre la exacta relación familiar entre Joaquín y José Domínguez Bécquer. La mayoría de los biógrafos habla de "primos lejanos", pero sin abundar en las fuentes. Rica Brown nos dice que es "hermano o primo de José, cuya figura se revela confusamente entre datos verídicos y suposiciones" (15). Rubio Jiménez nos habla de "tío segundo" (13) de Gustavo Adolfo y Valeriano Bécquer, pero no aclara el origen de esta afirmación. Parece ser que desde su más temprana edad, incluso antes de cumplir los dieciochos años de edad, y de acuerdo con los registros de la época, Joaquín Domínguez Bécquer ya era "miembro de la familia cuya cabeza es José Bécquer" (Brown 15).

${ }^{3}$ El término "pintoresco" fue usado por primera vez por Vasari en sus Vite pero, tal y como lo conocemos hoy, se origina en Gran Bretaña, en el siglo XVIII y se puede definir, de acuerdo con Henckmann y Lotter, "como un tipo de representación artística basada en unas determinadas cualidades como serían la singularidad, irregularidad, extravagancia, originalidad o la forma graciosa o caprichosa de determinados objetos, paisajes o cosas susceptibles de ser representadas pictóricamente" (191).

4 "La poesía es como la pintura: una cosa te gustará más, si la miras de más cerca; otra te gustará más si la miras de más lejos. Ésta requiere ser mirada a media luz; esta otra resiste la luz plena y resiste al ojo penetrante de la crítica. Aquélla te agradó la primera vez. Aquélla otra te agradará mil veces que la veas" (Horacio, 179).

${ }^{5}$ De cierta manera, a través de esta relación, "la escuela sevillana define su personalidad. Murillo, ajustándose de una manera perfecta a los ideales pictóricos del romanticismo: idealista en sus contenidos y académico en sus formas, es elevado a paradigma de artista nacional" (Hernando 166). 


\section{CAPÍTULO II}

\section{CARACTERÍSTICAS Y ANTECEDENTES DEL GÉNERO.}

Al volver al monasterio, después de haberme detenido aquí para recoger una tradición oscura de boca de una aldeana, allá para apuntar los fabulosos datos sobre el origen de un lugar o la fundación de un castillo, trazar ligeramente con el lápiz el contorno de una casuca medio árabe, medio bizantina, un recuerdo de las costumbres o un tipo perfecto de sus habitantes...

Desde mi celda, IV Gustavo Adolfo Bécquer

Dentro del corpus narrativo de Gustavo Adolfo Bécquer, las Leyendas pertenecen a una etapa muy concreta de su creación literaria, que se extiende desde 1858, fecha de publicación de su primera leyenda, "El caudillo de las manos rojas", hasta la publicación de su última leyenda, "La rosa de la pasión”, en 1864. Estos años constituyen un período de fecundísima labor literaria para Bécquer, en el que no sólo alcanzó un deseado equilibrio profesional y económico, sino también el reconocimiento como escritor. Algunas de las publicaciones más prestigiosas de la época --El Contemporáneo, diario del partido moderado, así como las revistas La Crónica, Revista Española de Ambos Mundos y La América-- reprodujeron en sus páginas estos relatos legendarios, que gozaron de una amplia acogida por parte de un público asiduo que las leía y las reclamaba. Estas leyendas se enmarcan, por su carácter, en el contexto del folletín o de la novela por entregas, y su difusión en estas publicaciones condicionó, de cierta manera, la temática y la estructura de las mismas. Además, las propias circunstancias de su elaboración, obligaba a su autor a 
mantener y activar la tensión narrativa de estos relatos en función de las entregas periódicas que se hacían, así como la aceptación por parte del público lector, que podía interesarse mucho más, pero en dependencia de los temas o la forma narrativa.

La leyenda que nos presenta Bécquer en el último tercio del siglo XIX, escrita en una prosa poética-plástica, más centrada en el ambiente y la atmósfera, en el cuadro, en definitiva, que en la acción --lo que la hace indiscutiblemente pictórica-era ya un género que había alcanzado en España una particular notoriedad desde comienzos del propio siglo ${ }^{1}$, en parte por el interés romántico por agruparlas, estudiarlas e incluso imitarlas. Durante los dos primeros tercios del siglo XIX, Agustín Durán, que ya había publicado los dos tomos de su monumental Romancero general o colección de romances castellanos, publica la Leyenda de las tres toronjas del vergel de amor(1853), relato que se enmarca en la poesía tradicional. La leyenda en verso de temática sobrenatural y maravillosa, elementos que no faltarán a las Leyendas, tiene en Ángel de Saavedra, duque de Rivas, su gran representante. José Zorrilla, por su parte, elabora leyendas de asuntos históricos, tradicionales y fantásticos, muy en sintonía con los temas de Bécquer. En este período, además, Cecilia Böhl de Faber (Fernán Caballero) traduce leyendas de origen alemán, y reúne y prepara colecciones de las españolas, en su afán de investigar el folclor andaluz, del que toma elementos costumbristas para escribir sus obras. Fue, precisamente, Böhl de Faber, a tenor de los documentos que se conservan, la que introdujo a Washington Irving en el mundo de las costumbres populares andaluzas; historias en las que éste se apoyó para escribir sus Cuentos de la Alhambra (1832). 
Una segunda versión de estos cuentos de Irving, hacia 1857, le sirve de referente al arabista, orientalista y lexicógrafo español, Francisco Javier Simone, para redactar su visión de las leyendas del palacio árabe, La Alhambra: leyendas históricas árabes. El trasfondo andaluz "arabizado" de este material literario --una herencia cultural muy cuestionable tanto en su sentido artístico como ideológico-- no pudo pasar inadvertido para Bécquer, en razón de sus orígenes y antecedentes artísticos andaluces, así como por el ambiente pictórico-costumbrista que lo rodeó durante su etapa en Sevilla, centro obligado del grand tour europeo, como ya hemos documentado. El escenario exótico andaluz es, sin duda, una de sus primeras influencias pictóricas.

Bécquer coincide, además, con otros escritores, como la propia Böhl de Faber, en la tarea de rastrear el pasado en busca de costumbres y monumentos, sobre todo cristianos, llamados a desaparecer por el empuje de la modernidad. Así, Cecilia Böhl de Faber es un referente en el procedimiento de insertar temas o motivos folclóricos en su obra narrativa. Bécquer compartió con ésta y con otros escritores de la época la creencia, herderiana en última instancia, "de que las costumbres del pueblo sencillo eran inherentemente 'poéticas' y que sus miembros eran incluso capaces de crear poesía" (Silver 115). Desde luego, en el caso de Bécquer, este material folclórico, presuntamente popular, va a sufrir una transformación literaria y pictórica considerable.

Por otro lado, estas narraciones legendarias de Bécquer, como destaca Rubén Benítez, "responden a la expresada finalidad de conservar bellezas y tradiciones" (63). Bécquer --el Bécquer tradicionalista-- es consciente de las huellas dejadas por 
el proceso de modernización, y así lo expresa a su regreso a Sevilla, tras una ausencia de casi diez años:

“[E]dificios, manzanas de casas y barrios enteros habían surgido al contacto mágico de la industria y el capital; por todas partes fábricas y jardines, posesiones de recreo y frondosas alamedas...;por desgracia muchas antiguallas --que no deben tomarse en un sentido despectivo; todo lo contrario-- habían desaparecido". (De la Banda y Vargas 134)

Como ocurre en el caso de otro poeta-pintor, Théophile Gautier, o como en los poetas parnasianos franceses, el retorno de Bécquer al pasado, su huida "romántica" hacia otros tiempos y espacios, es también un rechazo estético a su tiempo y entorno. Piénsese en sus recurrencias a algunos artistas barrocos, así como a los pintores románticos, prerrafaelistas y simbolistas, que beben, al mismo tiempo, de ciertas fuentes exóticas orientales. Sobre la época que le tocó vivir y su reacción a la misma, el propio autor comenta así en "La Nena", artículo de costumbres:

[E]sta atmósfera nos ahoga a veces; hay ocasiones en que ansiamos percibir un soplo de nuestra extinguida nacionalidad, y entonces, o abrimos el libro inmortal de Cervantes, u hojeamos algunas de las comedias de Calderón, o nos volvemos con la memoria al fondo de la provincia en que vimos la luz al nacer y en cuyas costumbres y en cuyos cantares se conserva aún el reflejo de nuestras costumbres y características. (Obras completas 524)

Hacia mediados del siglo XIX, la leyenda era ya un género literario muy popular en España, hasta llegar a ser considerada una presencia obligada y un éxito 
asegurado en los periódicos más leídos de la época. Cualquier aproximación a las hemerotecas de ese siglo sorprende siempre por la gran cantidad de textos literarios que contienen. La vía del periodismo era una salida airosa de las producciones literarias, que Bécquer supo aprovechar con éxito; y es precisamente en La Crónica, en 1858, como ya hemos mencionado, que aparece la primera leyenda de Bécquer, encontrada por sus amigos entre sus muchos papeles, y entregada a la redacción de ese periódico para su publicación, con el fin de recaudar algún dinero con que hacer frente a los gastos de la delicada enfermedad que ya lo aquejaba en ese año.

No podemos corroborar, sin embargo, con los datos que tenemos hasta la fecha, que hubiera otras leyendas ya escritas entre sus papeles, pero sí podemos afirmar que entre 1858 y 1860, año de publicación de "La cruz del diablo", no se publicaron otras leyendas bajo su nombre. Como señala Rica Brown, "con la publicación de esta segunda leyenda, Gustavo parece haberse dado cuenta de sus posibilidades, así artísticas como financieras, pues durante los tres años siguientes (1860-1863) aparecieron en la prensa nada menos que dieciocho de las veintidós leyendas que se conocen de él" (169).2

De toda la obra en prosa de Bécquer, las Leyendas son, sin duda, las más conocidas. Berenguer Carisomo considera que "[p]or su calidad e importancia, constituyen un punto capital, no ya de su bibliografía, sino de toda la bibliografía hispánica artística de aquel tiempo y momento" (14-15). Sin embargo, a pesar de los valores literarios de las mismas, tanto en la calidad del lenguaje que las recrea como en los aspectos narrativos, en los que se manifiesta una prosa de gran plasticidad y colorido, las rimas han sido el polo de atracción para la mayoría de los lectores 
durante muchos años, quedando los cuentos legendarios y el resto de su prosa relegados a un segundo plano, todavía mucho más distante de los críticos que de los propios lectores. Esto se debe, quizás, a que la leyenda era un género que, hacia el último tercio del siglo, se consideraba sumido en una etapa de decadencia, superado por las narraciones realistas que iban apareciendo en la época. Posiblemente, en parte, por esta coyuntura histórica, hubo un casi total abandono de la obra en prosa a favor de su obra poética. Esto pudiera explicar por qué Bécquer ha sido, y todavía lo es para muchos, "el poeta de las 'rimas' y solamente el poeta de las 'rimas'. Recitadas en voz baja o en voz alta, repetidas hasta la saciedad..., Bécquer es para el mundo el poeta por antonomasia, el autor de los versos sublimes y, como tal, fijo en su marco literario de hiedra romántica" (Berenguer Carisomo 5). Sin embargo, todo el resto de la rica obra becqueriana, apenas existe y, si exceptuamos algunos relatos, la poesía ha impedido ver y evaluar el resto de su obra: su prosa, y dentro de ésta, sus leyendas.

No debe extrañar, entonces, la casi total ausencia de estudios críticos sobre esta parte de su obra; y todavía muchos menos, que exista un estudio sobre la influencia de la pintura en su prosa. Para Arturo Berenguer Carisomo, "lo mejor de Bécquer es su prosa; casi estaría por decir, si no oliese a herejía, que es superior a su verso...; y para comprender al poeta en toda su integridad es indispensable fijarse en ella con morosa atención. Es entonces cuando se interpretan a la verdadera luz muchos misterios de aquel crear artístico" (6).

En su obra, El cuento español en el siglo XIX --obra que ofrece una completa visión del cuento español de ese siglo-- Mariano Baquero Goyanes señala: 
[Las leyendas de Bécquer] representan el triunfo del relato en prosa, ya que los que hasta ahora hemos estudiado de este tipo son muy inferiores a los relatos legendarios en verso del Duque de Rivas o de Zorrilla. Bécquer consigue el milagro de una prosa poética --pero prosa auténtica con valores narrativos-- sirviendo a unos asuntos que en emoción, misterio y belleza nada tienen que envidiar a los mejores de los autores citados. Las Leyendas de Bécquer suponen el logro de un género antes mediocre y topiqueramente [sic] romántico, y a la vez significan casi su fin, ya que de puro perfectas ningún otro relato de esta clase, posterior, podrá igualarse a los del escritor sevillano. El género decae sensiblemente y todas las manifestaciones subsiguientes parecerán torpes remedos de la obra de Gustavo Adolfo [Bécquer]. (221)

Además de la tradición, en las leyendas concurren otras influencias destacadas de la narrativa y el arte románticos: las narraciones históricas de Walter Scott, en cuanto a la orientación historicista de algunas leyendas; los relatos fantásticos de Tieck y Hoffman; las historias fantasmagóricas de Edgar Allan Poe; el cuento folclórico de Fernán Caballero, tal y como lo señalamos antes; pero también y sobre todo, la fecunda fuente de ideas y experiencias que se nutren del entorno artístico familiar; su propia formación pictórica en los talleres sevillanos de dibujo y pintura, a los que ya hemos aludido, y la presencia incuestionable de su hermano, el pintor Valeriano Bécquer. Destacan también en las leyendas --con un protagonismo singular--los paisajes de las regiones que recorrió en sus excursiones artísticas, casi 
siempre junto a Valeriano; paisajes que, además de la belleza, poseen las cualidades asimétricas y desiguales de lo pintoresco. Para Antigüedad y Aznar, "[l]a variedad pintoresca es la que otorga al artista la posibilidad de recrearse en los contrastes de formas y en los de luz y sombra con todas sus tonalidades" (94). No se excluyen, por otro lado, otras influencias, pero es incuestionable el papel fundamental de la pintura en la elaboración de las Leyendas.

Como es sabido y hemos documentado, desde su nacimiento hasta 1854, año en que marcha a Madrid en busca de mejores horizontes artísticos y literarios, el ambiente que rodea a Bécquer es fundamentalmente pictórico. La llegada de Bécquer a la corte no disminuye su interés en la pintura. De hecho, se verá fortalecida por la asistencia a museos, así como por las frecuentes visitas de su hermano Valeriano, hasta que éste decide trasladarse definitivamente a Madrid, así como por la ejecución de proyectos artísticos conjuntos; pero, sobre todo, fue determinante la estrecha colaboración entre ambos hermanos, la cual continuó y se intensificó a lo largo de sus vidas.

La leyenda becqueriana también responde, al margen de sus grandes aportes creativos, a la acepción tradicional de leyenda, que la define como una narración que incluye elementos de ficción, a menudo sobrenaturales, y que se transmite de generación en generación. Se sitúa, además, en un tiempo y lugar que resultan familiares a los miembros de una comunidad determinada, lo que aporta al relato elementos de verosimilitud. Además, aporta al paisaje, tanto físico como simbólico, una singular importancia plástica en las descripciones. Los hermanos Grimm definieron la leyenda "como un relato folclórico con bases históricas" (312), lo cual 
también se manifiesta en las Leyendas de Bécquer. Timothy R. Tangherlini nos da una definición mucho más actual e inclusiva: "La leyenda es una narración tradicional corta, de un solo episodio, altamente ecotipificada [sic]" (85). Es decir, ubicada en un tiempo y espacio específicos, "y realizada de modo conversacional, que refleja una representación psicológica simbólica de la creencia popular y de las experiencias colectivas, y que sirve de reafirmación de los valores comúnmente aceptados por el grupo a cuya tradición pertenece" (85).

Esta definición de Tangherlini también puede aplicarse a las leyendas becquerianas. Sin embargo, es importante señalar que el rasgo fundamental y distintivo de las mismas, por sobre todas las definiciones, no es la atmósfera de irrealidad ni la presencia de lo folclórico-histórico, a la manera de los hermanos Grimm; ni tampoco lo relacionado con las creencias populares de Tangherlini o Böhl de Faber; ni el lirismo presente en todas ellas por la prosa poética que utiliza Bécquer; ni siquiera esa clara relación entre el lenguaje poético --prosa poética, en definitiva-- y los ambientes, lo cual las acercan a sus Rimas. Lo que realmente hace únicas a sus leyendas es la manera en que Bécquer presenta las descripciones de los personajes y de los ambientes, tanto interiores como exteriores, sobre todos estos últimos, como si en realidad el autor las estuviera pintando sobre un lienzo y tratara de mostrarnos sus cuadros, intermedializados, a veces apelando a la imaginación y a su visualización, mediante el recurso de introducir un observador entre éste y lo narrado o de pedirle a un personaje --y a nosotros como lectores, pero, sobre todo, como espectadores-- que imaginemos o visualicemos una determinada escena. Bécquer utiliza varios recursos a los que nos referiremos en este trabajo. 


\section{II.1. Los temas de las "Leyendas"}

Los temas escogidos por Bécquer procedían de su acusado interés por el arte y la arqueología, así como por las tradiciones y la propia historia de España. Por otra parte, la localización de estos relatos les otorga rasgos de verosimilitud. Se trata de poblaciones, regiones y monumentos existentes y fácilmente reconocibles por los lectores, quizás con la única excepción de las leyendas indias. Sevilla, Toledo, Soria y sus territorios aledaños son algunas de las poblaciones en que se desarrolla la acción, junto con el afamado monasterio de Fitero, la parroquia de Santa Inés en Sevilla, la iglesia de San Saturio, las ruinas de San Polo, ambas próximas a Soria, y la catedral de Toledo. Sin embargo, el paisaje que rodea a los protagonistas de las leyendas, la "ambientación del cuadro", digamos, adquiere características sobrenaturales o fantásticas, dentro de la recreación plástica propuesta por Bécquer, que va de la tradición india expresada mediante intermedialidades de Claude Lorrain, en cuanto a los efectos de luz y color, pasando por un medievalismo prerrafaelista, a la visión exótica de los artistas románticos, sin olvidar las pinceladas de color local, propias del costumbrismo, una estética que le era particularmente atractiva en razón de la actividad pictórica del ambiente familiar. Hay en estos paisajes una idealización y una poetización tales, que suponen, sobre todo, la visión de un artista que aspira más a "pintarlas" con palabras que a narrarlas. Insisto, por otra parte, en que separar en Bécquer al poeta del prosista², y a éstos del pintor, resulta una tarea casi imposible, debido a que los límites entre unos y otros son sumamente borrosos, casi inexistentes. Al decir de García Viñó, "idéntica atmósfera, semejante temática, igual tonalidad" (24). A este comentario de 
Viñó habría que agregar, por sobre todo, la presencia de efectos sensoriales comunes, en los que predominan un tratamiento pictórico de la luz, la línea, el volumen, el color en todas su gama de matices y tonos, el contraste de luces y sombras, la pincelada breve y suelta en el tratamiento, precursora del impresionismo pictórico, como ya hemos mencionado. Como señala Baquero Goyanes, "su visión poética del mundo necesitaba de un instrumento literario más expresivo, flexible y amplio que el de las rimas. Éstas sólo le sirven para verter parte de su inquietud sentimental" (220). Bécquer halló ese instrumento en la pintura, su otra vertiente artística.

En otro aspecto, más de un crítico ha querido ver en estos relatos legendarios, imbuidos de una profunda nostalgia por el pasado, la admiración de su autor por la tradición española, por lo folclórico hispánico, de ahí que pueda afirmarse que tanto la estructura como los temas --a veces, tópicos-- de las leyendas becquerianas beben de las fuentes del folclor español y europeo. Berenguer Carisomo lo considera "una de las voces más claras y finas de lo folklórico traspasadas al ritmo de una forma literaria ejemplar" (17). Como también apunta Pascual Izquierdo, "las tradiciones populares estarán ligadas en Bécquer a la concepción de las leyendas como género artístico, siendo determinante el peso de la tradición en la gestación y orientación de su obra narrativa... Fundamentalmente, lo que lleva a cabo Bécquer en sus relatos legendarios es elaborar literariamente asuntos o motivos recogidos de la tradición popular" (29).

Por otro lado, Rubén Benítez destaca que “[e]n algunas leyendas, Bécquer recoge asuntos de la tradición; en otras, sólo motivos aislados. Pero aun cuando crea 
libremente, procura imitar los relatos populares que aseguran a sus narraciones un tono legendario" (57). Bécquer, creo importante insistir en ello, busca lo más folclórico del mundo rural, rescata, de cierta manera, la cultura popular, sus creencias y sus tradiciones. Basándose, precisamente, en el elemento tradicional en las Leyendas, el propio Benítez señala tres tipos diferentes:

La simple tradición transmitida en forma oral o escrita $y$ presumiblemente no elaborada sino en detalles secundarios; el relato ficticio sobre temas o motivos de la tradición popular elaborados literalmente, o sea, la "leyenda tradicional"; la "leyenda ideal", con remota base en la tradición, pero llena de rasgos maravillosos y de recursos de tipo poético similares a las manifestaciones de la fantasía popular. (106)

De acuerdo con José Pedro Díaz, una buena parte de las Leyendas, reproduce el mundo temático y emocional del romanticismo español, y que tanto su gusto por el color local, por el exotismo, por lo popular, por las tradiciones medievales, como el carácter de su imaginación fantástica, colocan esta parte de su prosa dentro de las líneas normales del romanticismo, aunque acaso una cierta fineza de ejecución, un dominio particularmente delicado y exacto de su instrumento verbal, la señalan como excepcional dentro de la producción romántica española. (192)

No cabe duda de que en esa "delicadeza" y "exactitud" del "instrumento verbal" que menciona José Pedro Díaz, y en las elaboradas descripciones ecfrásticas 
que aparecen en estos relatos, Bécquer manifiesta su entusiasmo de artista por los detalles plásticos, lo que constituye un singular aporte a la prosa romántica. Se trata, en síntesis, de una prosa plástica que Bécquer elabora a partir de un tejido de confluencias de sus vastos conocimientos de pintura, escultura y arquitectura y música, los que conjuntamente con los temas y motivos tradicionales, conforman "el tradicionalismo artístico", acuñado por Rubén Benítez. De acuerdo con este crítico, además, "[e]l interés de Bécquer por los relatos tradicionales forma parte de su concepción de la historia. Las manifestaciones de la fantasía popular integran orgánicamente el contenido del Volksgeist o espíritu del pueblo. Como la historia, ayudan a reconstruir los eslabones perdidos de esa totalidad espiritual" (92-93). Esta idea se ajustaba al interés de Bécquer por los relatos legendarios.

Por otra parte, siguiendo la corriente del romanticismo conservador y arqueológico de Chateaubriand, Bécquer defiende la fe en la tradición popular, base para él de la historia, frente al criterio filosófico y razonador entonces dominante. No debe resultar extraño, entonces, que los primeros relatos legendarios aparezcan, precisamente, en la Historia de los templos de España. Sin embargo, Bécquer no puede ser tomado como un escritor popular, al menos no en el sentido tradicional del término. Arturo Berenguer Carisomo, que estudió su prosa con profundidad, lo considera "un artista de recursos propios, de acento personal, de técnica particularizada, pero eso sí, en la entraña de muchas de sus leyendas, será siempre posible encontrar el germen anónimo que les da la vida" (17); esto es, la raíz del relato tradicional, del espíritu del pueblo, que tanto se afanó en revivir. 


\section{II.2. Los límites de la expresión verbal en la teoría poética de Bécquer}

Cuando se publica la primera leyenda en La Crónica, en los meses de mayo y junio, Bécquer es un escritor desconocido para la mayoría de los lectores. En cambio, cuando se publica la última de estas leyendas, ya es un escritor respetado y reconocido, que ejerce como periodista multifacético en la prensa moderada, que escribe en las publicaciones más importantes de la época, y que goza, además, del proteccionismo oficial por parte del gobierno moderado de González Bravo. Entre estas dos fechas, que abarcan una etapa de seis años, Bécquer escribe las cuatro Cartas literarias a una mujer (1860-1861) y las nueve cartas incluidas en Desde mi celda (1864), dos obras que conforman una suerte de manifiesto artístico-literario, cuyo análisis minucioso resulta esencial para entender su "poética" o teoría del arte, desde una perspectiva semiótico-cultural. En el primer caso, porque en las cartas se esbozan las ideas en torno a la construcción de lo visual, esto es, del objeto visual, como traducción posible de la realidad; como "texto artístico" no verbal intermedializado en un texto literario; pero, además, como complemento indiscutible del objeto verbal, en tanto y en cuanto aceptemos la literatura como un sistema de producción cultural que está en relación directa con otros sistemas y con su propio contexto. En el segundo caso, porque las cartas de Desde mi celda complementan y reafirman las ideas estéticas que regirán toda su obra. En ambos casos, y en las referencias que se encuentran en textos de carácter autobiográfico, Bécquer se interesa, específicamente, por algunos aspectos relacionados con la incapacidad de la palabra para plasmar ciertas escenas y con la capacidad de las imágenes para completar el sentido de éstas. 
La teoría poética de Bécquer se halla dispersa por toda su producción literaria; sin embargo, podríamos aislar algunos textos de la misma en los que se nos presenta de una forma más clara. Estos son: las Rimas, particularmente de la I a la XI y la XXI; el Comentario a la soledad de Augusto Ferrán; la Introducción sinfónica; las ya mencionadas Cartas literarias a una mujer y las cartas de Desde mi celda. Nos referiremos, sobre todo, a estos dos últimos textos, que son de importancia capital para nuestra investigación, fundamentalmente el primero de ellos, por ser un texto coincidente con la elaboración de las Leyendas.

La mayoría de los críticos de Bécquer apuntan a ciertos elementos fundamentales de esa teoría. A saber: Bécquer ha querido enfatizar la imposibilidad de estudiar la poesía desde presupuestos puramente teóricos que excluyan los fenómenos del alma y los secretos de la vida, imposibles de diseccionar --como lo haríamos con un cuerpo sin vida-- y mucho menos analizarlos únicamente con palabras.

Para Bécquer, lo verdaderamente importante no es el resultado del poema, sino la génesis del mismo. El propio Bécquer manifestaba en Cartas literarias a una mujer que "sobre la poesía no ha dicho nada casi ningún poeta; pero, en cambio, hay bastante papel emborronado por muchos que no lo son" (Obras completas 458 ). Luego añade: "El que siente se apodera de una idea, la envuelve en una forma, la arroja en el estadio del saber, y pasa. Los críticos se lanzan entonces sobre esa forma, la examinan, la disecan y creen haberla entendido cuando han hecho su análisis..., pero los fenómenos del alma, el secreto de la vida, ¿cómo se estudian en un cadáver?" (Obras completas 458). Estamos, pues, ante una de las muchas 
imposibilidades de la palabra para expresar ciertas ideas, lo que manifiesta una y otra vez, como ya hemos analizado.

Bécquer destaca, por otra parte, el concepto de poesía, al que sólo es posible acercarse por medio de la intuición poética, señalando las profundas diferencias que existen entre poesía, por una parte, y entre verso y prosa, por la otra, aunque se trata en realidad de otras formas expresivas que utiliza la poesía. Este último es el recurso utilizado por Bécquer en las Leyendas; escritas en prosa, pero en una prosa distinta, abundante en matices, una prosa poética. A este respecto, Pascual Izquierdo establece una estrecha relación entre la prosa y la poesía de Bécquer al señalar que “[r]imas y leyendas forman parte del 'mismo mundo de la idea' con evidentes puntos de contacto entre sí, tanto temáticos como estilísticos, y con formulaciones expresivas que sólo se diferencian en la intensidad" (Leyendas 26). Esta idea de Pascual Izquierdo subraya el concepto de Bécquer como poeta-prosista y nos remite al modelo germánico de las baladas, escritas en prosa poética, las que, traducidas e imitadas en el romanticismo español, sirvieron de modelo al cuento legendario de raíz popular, en una primera fase. Pero, además, nos remite a una corriente decimonónica, que revive el romance tradicional castellano como vehículo expresivo de los textos legendarios de la época. Julio Cejador ha visto en esta tendencia "la verdadera épica castellana del siglo XIX" (422). Cabe subrayar aquí que la interacción semiótica estética entre todos estos discursos, no se da en un espacio de taxonomías distantes o excluyentes, sino en un espacio de inclusiones. A esto cabe agregar el carácter pictórico de la prosa-poética becqueriana, que hace del texto un espacio de confluencias literarias y pictóricas en el que convergen la 
palabra y la imagen en un diálogo inter-artístico verdaderamente enriquecedor. Otro aspecto de su teoría literaria analiza la escritura como un acto de creación artificial, que resume la conocida frase de Bécquer: "cuando siento, no escribo" (Obras completas 460). Así, pues, declara en Cartas literarias a una mujer:

Guardo, sí, en mi cerebro escritas, como en un libro misterioso, las impresiones que ha dejado en él su huella al pasar. Estas ligeras y ardientes hijas de la sensación duermen allí agrupadas en mi memoria hasta el instante en que, puro, tranquilo, sereno y revestido, por decirlo así, de un poder sobrenatural, mi espíritu las evoca... Entonces, no siento ya con los nervios que se agitan, con el pecho que se oprime, con la parte orgánica y material que se conmueve al duro choque de las sensaciones producidas por la pasión y los afectos. Siento, sí, pero de una manera que puede llamarse artificial; escribo como el que copia de una página ya escrita; dibujo como el pintor que reproduce el paisaje que se dilata ante sus ojos y se pierde entre la bruma de los horizontes. ( Obras completas 460$)$

Se trata de una doble tarea de "almacenamiento" de las impresiones y sensaciones que ha experimentado Bécquer, para luego recuperarlas y transformarlas en materia poético-pictórica, una vez superada la emoción inicial. Podríamos hablar de una labor de estudio que completan, a un nivel pictórico, los apuntes o bocetos realizados a priori por el artista y que fueron sometidos a un proceso de depuración de lo superfluo, de lo que no constituía materia pictórica para su visión artística. 
Así, Bécquer, en contacto directo con la pintura desde su infancia, concibe la construcción literaria, además, como un proceso de construcción pictórica. Esos bocetos, sin embargo, pueden ser de dos tipos: los que responden a las impresiones visuales, esto es, lo que se conoce en arte como "el tránsito de la mirada"; y, por otro lado, el apunte artístico, el boceto material que dibuja el artista como paso previo a la elaboración minuciosa y a la (re)creación de la realidad. Aquí es donde el conocimiento técnico de la pintura y el uso de términos pictóricos se refleja con mayor intensidad.

En Palimpsestes. La littérature en deuxième degré, Gérard Genette se refiere a la imagen de un texto que se superpone a otro al que no oculta del todo, sobre el mismo pergamino, sino que lo deja ver por su transferencia: "On entendra donc, au figuré, par palimpsestes (plus littéralement: hypertextes), toutes les oevres dérivées d'une oevre antérieur, par transformation ou par imitation" (579). Por lo tanto, toda lectura posible de un texto con estas características, debe hacerse, de acuerdo con Philippe Lejeune, mediante una "lecture palimpsestueuse" (557), que el propio Genette llamó “lectures relationnelles (lire deux ou plusieur textes 'en fonction' l'un de l'autre)" (557). Esto nos lleva a considerar si por la presencia de descripciones ecfrásticas y de un discurso eminentemente plástico en las Leyendas no podríamos hablar, también, de una lectura "relationnelle" o "palimpsestueuse" de estos relatos legendarios, si partimos de que unas "imágenes visuales y auditivas o acústicas" han sido superpuestas al texto para complementarlo --es decir, para incrementar su comprensión desde otras perspectivas-- pero son todavía algo visibles a través de éste, como ocurre en los palimpsestos que no llegan a ser borrados del todo. En ese 
sentido, el hipertexto debe leerse en su relación con el hipotexto imagístico-acústico, ya que sin éste la comprensión de aquél sería definitivamente incompleta.

Genette denomina transtextualidad o trascendencia textual "à tout ce qui le met [el texto] en relation --manifeste ou secrète-- avec d'autres textes" (7), lo cual enriquece considerablemente la definición de Julia Kristeva y concreta la definición más genérica de Rifaterre. Además, para Genette, la hipertextualidad es una forma de transtextualidad: "toute relation unissant un texte B (que j'appellerai 'hypertexte') à un texte antérieur A (que j'appellerai, bien sûr, 'hypotexte)" (13). Habríamos de añadir, siguiendo las pautas de Segre, a todo lo que pone el texto en relación con otros textos literarios o con textos de naturaleza artística no literaria, lo que hemos llamado en este trabajo "textos no verbales". Me refiero a los recursos multisensoriales empleados por Bécquer.

\section{3. Las intermedialidades visuales como técnicas narrativas}

Dentro de las características de sus Leyendas, a las que nos referiremos más detalladamente a lo largo de este trabajo, Bécquer se interesa por privilegiar lo visual como recurso literario, mediante la utilización de técnicas y términos esencialmente pictóricos trasladados al ámbito literario; así como por los complejos procesos de la creación literaria y artística, procesos que resume su conocida cita:

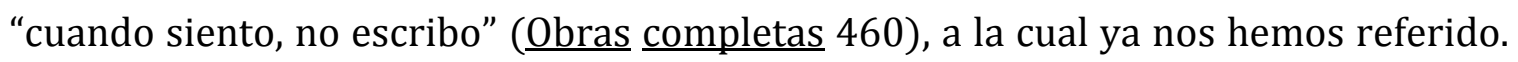
En este sentido, Bécquer concreta en términos artísticos y literarios su interpretación del objeto visual, capaz de reconstruir el cuadro ausente, mediante una labor serena y analítica de "estudio", más propia de un pintor en su estudio que de un narrador. 
Por otra parte, Bécquer se vale de obras materiales (reales o conocidas) o inmateriales (inexistentes), así como de elementos pictóricos adquiridos en su etapa de formación artística o en sus posteriores estudios y lecturas sobre la historia del arte. Estas imágenes aparecen insertadas, a modo de interdiscursividades, en el ámbito narrativo de las Leyendas. Además, Bécquer se interesa por la construcción de imágenes ecfrásticas, esto es, por la elaboración de una "écfrasis" o imagen pictórica, a través de la palabra, en tanto que interdisciplinaridad o intermedialidad comparativas, de gran importancia como sustituto o complemento visual del objeto verbal, casi siempre "inútil" o incompleto, de acuerdo con su visión estéticofilosófica. En ese sentido, se interesa por la capacidad de las imágenes para completar o sustituir las descripciones verbales carentes de imágenes visuales, así como por los procesos de la intertextualidad visual o "interdiscursividad", en términos de Cesare Segre, como categoría totalizadora, en tanto que sistema de referencias plurales: discursos literarios, musicales, pictóricos, arquitectónicos, entre otros; esto es, la relación entre un texto literario y otro de naturaleza artística no literaria.

Heinrich F. Plett llama "intermedialidad" a la intertextualidad visual, es decir, la relación entre sistemas sígnicos o medios, teóricamente distintos. En el caso de las Leyendas, los límites de estos sistemas llegan a desdibujarse, aunque no a borrarse del todo, como en los palimpsestos de Genette, a los que hemos aludido antes. El espacio de convergencias creado por Bécquer --espacio en el que concurren recursos y elementos que son parte de un discurso propio y distintivo-- coinciden imágenes sensoriales de muy diverso signo, pero, sobre todo, pictóricas. Ambos 
conceptos, interdisciplinaridad e intermedialidad, se enmarcan dentro de la trastextualidad, y constituyen aportes necesarios a una diversidad de acercamientos, como los que proponemos, en torno a la especificidad de unas relaciones que hacen confluir la imagen y la palabra en un mismo espacio secuencial.

En las Leyendas se produce, además, una simbiosis intertextual; un fenómeno cultural que profundiza en las relaciones entre una semántica del arte y una poética del imaginario visual, que afecta la recepción del destinatario en tanto que lector-espectador. En ese sentido, se demanda de éste una vasta cultura y niveles de interpretación artísticos para que sea capaz de (re)crear, a través de la imaginación icónica, ese universo de las estructuras objetivo-materiales del texto, así como las subjetivo-comunicativas del "acto" de interpretar los referentes visuales; esto es, las descripciones ecfrásticas.

Uno de los desafíos de la teoría de la recepción se basa, precisamente, en el problema de la "obra abierta" como polivalencia interpretativa. En este sentido, Pozuelo Yvancos acota lo siguiente en relación con la "interpretación": "La recepción tiene, sí, una dimensión social de competencia, pero también es un fenómeno de creación de significado que ninguna obra posee definido o cerrado. La importancia que la recepción tiene... está en relación directa de su indisoluble unidad con el problema de la interpretación" (109). Luego, aclara: "No es el objeto artístico un objeto a ser recibido o un problema de percepción. La propia objetividad textual es creada por la lectura, de modo que recepción, interpretación y límites del objeto artístico-literario son vertientes de una misma cuestión" (110). 
Podemos deducir, basados en éste y otros argumentos relativos a la recepción, que el grado de interpretación de los recursos ecfrásticos --utilizados en nuestro caso por Bécquer-- está en relación directa con la capacidad de recepción de éstos por parte del lector-espectador; capacidad que determina el mayor o menor grado de conocimientos sobre las técnicas pictóricas empleadas o sobre las referencias implícitas a la historia del arte. Aun así, el lector es capaz de recibir una “impresión" --en el sentido pictórico del término-- del cuadro ecfrástico, lo que supone un gozo estético único para el destinatario (lector-espectador), sean o no reconocibles o identificables por su parte los referentes estéticos o las técnicas pictóricas utilizados.

La écfrasis becqueriana, debe ser vista, además, en su doble papel de descripción visual de una obra material --recreada con mayor o menor fidelidad a ésta--, o de una obra inmaterial, únicamente (re)creada en el texto, casi siempre referida al estilo de un artista determinado. En ambos casos, la interpretación o comprensión del sentido es un acto mucho más complejo que la comprensión del significado. Éste puede limitarse al reconocimiento lingüístico y es un acto con inferencias limitadas.

La comprensión del sentido, sin embargo, entraña una actividad mucho más abarcadora, más completa, por cuanto recaba del lector-espectador los conocimientos, así como las experiencias y referencias que le permitan la "traducción" de las interdiscursividades que aparecen en el texto. En definitiva, desde Bajtín a Kristeva, pasando por Eco y un dilatado número de teóricos de la literatura, todo texto termina siendo la absorción o transformación de otro(s) 
texto(s); e incluimos en esta afirmación los textos no-verbales a los que aludimos en este trabajo.

Es sabido, por otra parte, que el rasgo común de todas las artes es que evocan imágenes, por el medio que sea, apelando, por tanto, a los sentidos, especialmente a la vista. Por ello, de acuerdo con Wimsatt, "en tanto que utiliza imágenes visuales, la literatura es 'pintura hablante', y, puesto que las imágenes pictóricas se ofrecen abiertamente para ser vistas, entonces la literatura sería claramente un arte imagístico" (41). Si concordamos con este argumento de Wimsatt, que también es el de ut pictura poesis, debemos concluir, entonces, que la función del arte es evocar imágenes, por lo que la pintura y la literatura pueden aproximarse en la medida --e intensidad-- en que este acercamiento tiene lugar. Lo visual también colabora, en gran medida, con la pretensión de presencia en la obra literaria, ayudándola a aproximarse al "ser" de las cosas y a cobrar con ello la vivacidad de lo existente. Como destaca Lee: "Durante dos siglos, los críticos pensaron que era la vividez pictórica de la representación o, más precisamente, de la descripción --en el poder de pintar en el ojo de la mente las imágenes claras del mundo exterior de la misma manera que el pintor las registraría en el lienzo-- donde el poeta principalmente se parecía al pintor" (4).

El término retórico para esta "vividez" o vivacidad de la presentación es la energeia, un concepto crucial, que implica alcanzar, en el discurso verbal, una cualidad natural. De acuerdo con Hagstrum, "Plutarco, Horacio y los críticos helenísticos tardíos y romanos consideraban que la poesía era efectiva cuando alcanzaba la verosimilitud, cuando se parecía a la naturaleza o a una representación 
pictórica de la naturaleza" (12). Para la energeia, en el sentido que le otorga Plutarco, la analogía con la pintura es importante, pues la intensidad de la representación estaba en relación directa con la posibilidad --y capacidad-- de observación del espectador, en lo que el sentido de la vista podía captar. Para Bécquer, la vivacidad de una descripción no se logra si el lector no puede "ver" o "imaginar" visualmente el objeto visual, de ahí que el papel activo del destinatario (lector-espectador), en ese sentido, sea esencial. Por eso nos pide "imaginar" en "Los ojos verdes" --"cuento con la imaginación de mis lectores" (Leyendas 126)-- o apela, en otros casos, a imperativos como "mira", "figuraos" o "imaginaos", entre otros recursos para despertar la imaginación de lector, dentro de un sistema de signos (o sígnico) no verbal.

En ese sentido, y es importante destacarlo, Bécquer le pide al lector como destinatario, pero, sobre todo, como espectador, que imagine o visualice el objeto visual que ha sido "narrado" mediante un objeto verbal, la écfrasis. Los conceptos de “destinador" y “destinatario" están tomados de Jakobson, el cual los define así:

[S]on diferentes de emisor y receptor, tal como los postula la teoría de la información que, al limitar su actuación a un 'hacer' respectivamente emisivo y receptivo, los concibe, según sugiere Greimas, como 'instancias vacías', limitados a meros polos de un 'continuum' de comunicación (en el sentido informacionalista, de paso de información). Por el contrario, los conceptos de destinador y destinatario sugieren una posibilidad de dinamismo en el proceso comunicacional en el que interactúan". (Lozano et al 41-42) 
Utilizaremos, pues, los conceptos de destinador y destinatario, tal y como los hemos explicado, porque entendemos que se demanda una participación activa en el proceso de la (re)construcción de lo visual en estos relatos tradicionales.

\section{4. La Historia de los templos de España como antecedente de las "Leyendas"}

A sólo dos años de su llegada a Madrid, Bécquer acomete un ambicioso proyecto cultural, concebido para trazar la historia del cristianismo a través de los monumentos religiosos de España: la Historia de los templos de España. Esta obra se hallaba en línea de continuidad con otros referentes españoles y europeos, en los que la arqueología, la arquitectura y las artes en general jugaron un papel preponderante en la reconstrucción del pasado. El interés por la historia nacional -como en toda época de crisis-- estaba en sus mejores momentos; la evocación imaginativa de muchos aspectos de la Edad Media suscitaban un interés desmedido en la población, que comenzó a interesarse en sus tradiciones, modos de vida, costumbres, monumentos artísticos y religiosos, así como en los hechos heroicos, que encontraban eco en la prensa de la época a través de artículos ilustrados sobre estos aspectos o de algún hecho que tuviera relación directa con ellos.

En su Teoría y crítica del romanticismo español, Derek Flitter enfatiza lo siguiente:

[E]l crítico catalán Pablo Piferrer fue uno de los impulsores detrás de Recuerdos y bellezas de España, un proyecto mastodóntico que envolvía la publicación, en fascículos, de estudios acerca de la historia, tradiciones y otras bellezas de las distintas regiones de España. Percerisa, colega de Piferrer, declaraba que la inspiración 
para el trabajo provenía del Romancero y de Les Aventures du dernier Abencérrage, de Chateaubriand. (162)

Desde fecha muy temprana, los críticos reconocieron la importancia capital de estos "estudios históricos y artísticos", como el propio Bécquer los llamaba, para el desarrollo ulterior de la obra becqueriana, sobre todo de las Leyendas. El primero en referirse a la Historia fue Julio Nombela, y lo hace con la agudeza del crítico:

La obra debe titularse "Los templos de España" y contener la más amplia y detallada descripción de cuanto en nuestra patria representan el sentimiento religioso, la devoción, la piedad y el arte sobre sus múltiples aspectos. No se trataba de un estudio simplemente arqueológico, de una descripción técnica más o menos detallada, como las que habían hecho algunos eruditos españoles, muy meritorias, muy documentadas; pero más labor de fotógrafos que de pintor artista. Lo que Gustavo pretendía era hacer un grandioso poema en que la fe cristiana, sencilla y humilde, ofreciese el inconmensurable y espléndido cuadro de las bellezas del Catolicismo. Cada catedral, cada basílica, cada monasterio, sería un canto del poema. La idea, el sentimiento, estarían expresados por la fábrica con el mármol, la madera, el hierro, el bronce, la plata, el oro, las piedras preciosas al servicio de artistas, arquitectos, pintores y escultores. A estas espléndidas formas darían alma la oración, la liturgia, el sencillo, severo y solemne canto llano, las melodías del órgano, los símbolos de los dogmas, la elocuencia sagrada. (Cit. por Rubén Benítez 70) 
Destaca, sobre todo, en este juicio de Nombela la función de "pintor-artista" que le otorga a Bécquer, así como la mención del "cuadro de las bellezas del Catolicismo", como resultado de la obra de un artista plástico; es decir, ya a la

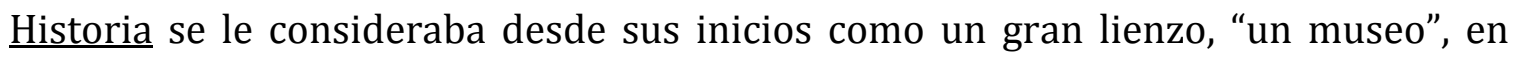
palabras del propio Bécquer. La visión pictórica; el hecho de concebir la obra como una pintura de "Los templos de España"; el título que tan acertadamente le confiere Nombela --obviando la parte histórica o quizás subordinándola a la artística por ser ésta, a los ojos de su autor, la de mayor importancia-- la marca desde su concepción como un proyecto literario distinto, con características muy peculiares. Para Rica Brown, una de las mejores biógrafas de Bécquer, por otro lado, "[l]a preparación (por el estudio, las lecturas y la meditación) de tanta materia sobre la historia de la cristiandad y sus edificios no sólo le ensanchó los horizontes poéticos, sino que le proporcionó una serie de posibles temas para sus leyendas" (86). Y luego añade: “Las de fondo toledano, por ejemplo, 'La ajorca de oro' (publicada en 1861), 'El Cristo de la calavera' (1862), 'Tres fechas' (1862), 'El beso' (1863) y 'La rosa de la pasión' (1864), bien pueden haber sido ideadas durante este período de estudio intensivo de las tradiciones y de la historia de la vetusta ciudad imperial" (86). Además, no cabe duda que los numerosos bocetos artísticos que Bécquer realizó durante esta etapa preparatoria, tal y como prueban sus comentarios en "Tres fechas", narración probadamente autobiográfica (pero no una leyenda, como señala Brown), además de otros comentarios, apuntan en esa dirección. Por lo tanto, nos es lícito afirmar que sobre este trasfondo histórico-artístico se enmarca la creación, no sólo de la Historia de los templos de España, sino de una buena parte de las 
Leyendas, que deben a los estudios llevados a cabo por Bécquer para esa obra, tanto en la documentación escrita como en sus apuntes artísticos, muchos de los elementos que luego utilizaría en los relatos legendarios. Por lo tanto, la Historia viene a ser, también, la "historia preliminar de las Leyendas".

Es indudable, por otra parte, que Bécquer no fue indiferente a la obra de Chateaubriand, y muy particularmente a Génie du Christianisme. Robert Pageard señala, con relación a la Historia de los templos de España, que "la idea directiva, apologética, era la de El genio del Cristianismo, de Chateaubriand" (149). La atracción por lo maravilloso cristiano, y muchas de las técnicas descriptivas de tumbas, templos, santuarios y otros objetos religiosos --muy en el interés de Bécquer por la arqueología y el arte-- se perciben tanto en la Historia de los templos de España y en la Leyendas, como en la mencionada obra de Chateaubriand.

No parece, pues, haber dudas de que en la Historia y en los cuentos legendarios de Bécquer se observan trazos de Génie du Christianisme. Chateaubriand, por otra parte, fue un referente obligado en la obra de Bécquer, tal y como prueban las numerosas alusiones a este escritor y a su obra en los textos biográficos sobre Bécquer, con independencia del aspecto religioso.

En el capítulo dedicado a la arquitectura árabe española, "El Cristo de la luz, bosquejos sobre la arquitectura árabe española", Bécquer se detiene para señalar, a manera de observación preliminar, lo siguiente:

[L]a multitud de distintos estudios que en ella se aglomeran y que le dan, por decirlo así, un carácter enciclopédico, harán de sus páginas un inmenso museo, propio para mostrar en conjunto, y como en un 
vasto panorama, todas las más notables producciones de los diferentes estilos arquitectónicos en que abunda nuestra patria. En esta galería, el árabe se encontrará en el importante lugar que le corresponde, aunque siempre teniendo presente que en el discurso de la narración, las cuestiones de arte se hallan obligadas a dejar un espacio digno a la historia eclesiástica y política, razón poderosa por la que, sin pecar de ligereza en este asunto, pondremos un empeño particular en ser concisos. ( $\underline{\text { Obras completas } 992)}$

La observación señalada por Bécquer, la "razón poderosa", sin embargo, no corresponde con el resultado final de estas descripciones ecfrásticas. Se trata, más bien, de un recurso narrativo que utiliza para "pintar", mediante una descripción verbal, lo que antes niega por imposible; o bien rechaza la posibilidad de describir el objeto plástico, aunque en la argumentación negativa se lleve a cabo, de hecho, la (re)creación ecfrástica. Se trata, en su caso, de un ejercicio retórico. En la descripción de la segunda época de la arquitectura árabe toledana, como lo hace en innumerables ocasiones, Bécquer insiste, una vez más, en la "inutilidad de las palabras", y destaca la capacidad indiscutible de las imágenes como recurso estilístico incuestionable para objetivar sus impresiones. Así, destaca:

Imposible sería el querer describir con palabras la brillante metamorfosis que en esta edad experimentó el arte que hemos visto en los siglos anteriores seguir tímidamente el sendero de la imitación, ensayando con pobreza y miedo, alguna que otra idea original. Sus formas groseras y pesadas han adquirido una esbeltez y una gallardía 
admirables; sus arcos, compuestos de mil y mil líneas atrevidas y nuevas se sostienen sobre columnas tan frágiles que no se concibe que pudieran soportar los muros, si estos a su vez no fueran calados y ligeros como el rostrillo de encaje de una castellana; las geométricas combinaciones de sus lacerías se complican y enredan entre sí de un modo inconcebible, y cada capitel, cada faja, cada detalle, en fin, de estas magníficas creaciones, son a su vez una obra artística maravillosa, en la que otros detalles secundarios aparecen a los ojos del observador y lo asombran por su delicadeza, su novedad y su número. ( Obras completas 996)

El recurso empleado aquí, y que veremos ampliamente representado en las Leyendas es significativo en más de un sentido, pues coloca a la Historia como antecedente inmediato e indiscutible en la utilización de estos recursos ecfrásticos que constituyen el propósito de nuestra investigación. En la descripción de la Basílica de Santa Leocadia, Bécquer apela a la inclusión del narrador:

A nuestra izquierda y escondiéndose por intervalos entre el follaje de sus orillas, el río se alejaba besando los sauces que sombrean su ribera y estrellándose contra los molinos que detienen su curso hasta bañar las blancas paredes de la fábrica de armas que aparece en su margen en medio de un bosque de verdura. Cuanto se ofrecía a nuestros ojos formaba un conjunto pintoresco; pero diríase al contemplarlo, que sobre aquel paisaje había extendido el otoño ese velo de niebla azulado y melancólico en que se envuelve la naturaleza 
al sentir el soplo helado de sus tardes sin sol; ese silencio profundo, esa vaguedad sin nombre, imposible de expresar con palabras, que apoderándose de nuestro espíritu lo sumerge en un océano de meditación y tristeza imponderable. Claudio Lorena en algunos de sus maravillosos paisajes ha logrado sorprender su secreto a la naturaleza y ha reproducido ese último adiós del día con todo el misterio, con toda la indefinible vaguedad que lo embellece. (Obras completas 953)

Llaman la atención varios elementos interesantes en esta descripción ecfrástica becqueriana. Ante todo, el ángulo desde el que observa el narrador. Pareciera, desde la pluralidad narrativa del comienzo, que contemplamos el paisajecuadro junto al narrador-pintor, de tal manera que "a nuestra izquierda", podemos observar el río en su recorrido y los árboles que bordean su ribera, tal y como nos lo muestra nuestro acompañante. La referencia concreta de la dirección del río, es decir, "a la izquierda", nos sitúa, de hecho, en el mismo sitio en que se encuentra el narrador. Por lo tanto, su visión del paisaje es la misma que tenemos nosotros en tanto que lectores-espectadores del cuadro. Luego, "la imposibilidad" de describir con palabras el paisaje, nos hace "verlo", precisamente por el intenso valor plástico de la descripción elaborada por Bécquer, en la que confluyen la interpretación, el vocabulario y la visión de un artista. Nuevamente, se vale Bécquer de ese recurso para describir el paisaje "sin describirlo", valga la paradoja, esto es, haciendo que lo contemplemos al tiempo que asistimos a su descripción ecfrástica mediante la pintura con palabras. Se trata, además, de un paisaje "pintoresco" en el que las veladuras azulosas parecen cubrir el cuadro, las blancas paredes de la fábrica y la 
verdura del paisaje; eliminando contornos, desdibujando sus elementos compositivos, y haciéndonos sumergir en esa atmósfera de misterio. Por último, la referencia a Claude Lorrain, cuya obra emerge una y otra vez en las Leyendas como un referente artístico. Bécquer ha querido contemplar el paisaje con los ojos de un pintor, y éste ha sido Lorrain, el pintor de los efectos de luz, de las vaguedades atmosféricas, "the painter of Twilight Haze" (King, 76). Para King, "Claude uses the twilight not to obscure nature but in order to have a kind of light that has enough substance to be painted" (76). La mención de éste y otros pintores (Rembrandt y Murillo, entre otros) en la prosa becqueriana, nos lleva a considerar sus descripciones ecfrásticas en el marco de las características pictóricas de estos reconocidos artistas, fundamentalmente, aunque no son los únicos.

En las Leyendas, la influencia de Chateaubriand también destaca en el protagonismo de la arquitectura y de las demás artes, así como por la inserción de las ruinas en medio del paisaje natural, fundiéndose en una plasticidad parnasiana. En las historias de los templos, la arquitectura, la escultura, la pintura y la música se organizan en un todo armonioso, como si de una composición plástico-musical se tratara. Sin embargo, el proyecto se redujo a la publicación de un primer tomo, en donde a la descripción arquitectónica y artística de los templos toledanos y sus interiores, se aúnan tradiciones legendarias relacionadas con el propio inmueble o con imágenes de su interior. El trabajo de investigación llevado a cabo por Bécquer para este proyecto, además de los numerosos apuntes del natural que tomó durante la dilatada etapa de gestación de esta Historia, fueron el necesario apoyo para la creación de sus relatos legendarios. Bien porque sólo pudo publicar un primer tomo 
o por cualesquiera otras circunstancias, las Leyendas son, salvando los temas en algunas de ellas, la continuidad de la Historia, al menos en sus aspectos formales.

En la introducción a la Historia, Bécquer declara que "la tradición religiosa es el eje de diamante sobre el que gira nuestro pasado. Estudiar el templo, manifestación visible de la primera, para hacer en un solo libro la síntesis del segundo: he aquí nuestro propósito" (Obras completas 907). Las tradiciones populares y las descripciones artísticas aparecen, pues, desde fecha muy temprana en la obra de Bécquer, ligadas a sus relatos en prosa, y serán, sobre todo, el referente obligado en la concepción de estos relatos, tanto en el aspecto narrativo como en el artístico. Por ello, en las Leyendas, fácilmente logramos reconocer al hijo del pintor José Domínguez Bécquer; al alumno del pintor Cabral Bejarano, su primer maestro de dibujo; al "tío" Joaquín Domínguez Bécquer, en cuyo taller aprendió los secretos de la composición pictórica, de la luz y del color; así como al inseparable hermano de Valeriano Bécquer, pintor de costumbres, con quien Bécquer mantuvo una especial relación artística, además de fraternal. Pero también podemos reconocer al músico dotado de gran talento y sensibilidad, para quien la música era otra de sus grandes pasiones. De acuerdo con Pascual Izquierdo, en las Leyendas alcanza Bécquer "sus más altos valores de sensorialidad, plasticidad, armonía musical y suntuosidad estética" (Leyendas 33). Otro rasgo que debemos destacar es la presencia de lo exótico-oriental en, al menos, las dos leyendas del ciclo narrativo hindú, donde destacan los valores sensoriales del color de la última etapa prerrafaelista, así como de los pintores los simbolistas. 


\section{NOTAS AL CAPÍTULO II}

${ }^{1}$ Hemos incluido sólo aquellas narraciones legendarias que los críticos, a tenor de las últimas revisiones, consideran inequívocas leyendas, y que han sido reproducidas en la edición crítica de Pascual Izquierdo. Siguiendo este criterio hemos excluido todas aquellas narraciones que los becqueristas consideraban de dudosa autoría: "La voz del silencio" y "La fe salva". Asimismo, hemos excluido "Tres fechas", porque se trata de una narración autobiográfica, aunque en otras ediciones aparece como leyenda; tal es el caso de la obra de Rica Brown, por ejemplo, si bien "Tres fechas" provee abundante información sobre la actividad pictórica de Bécquer, por lo cual la hemos citado en más de un capítulo.

El criterio que utilizaron los críticos becqueristas viene dado por las ediciones de las obras de Bécquer, comenzando por las ediciones periodísticas en que aparecieron por primera vez estas narraciones. Una segunda guía para los críticos fue la edición de la obra de Bécquer preparada por Campillo, Ferrán y Rodríguez Correa. La tercera guía se apoya en la rigurosa edición de Rubén Benítez, que hemos consultado y citamos a lo largo de este trabajo. Las diecisiete leyendas resultantes de esos estudios difieren de las veintidós que menciona Rica Brown en su enjundioso trabajo de investigación, publicado en 1963 con prólogo de Vicente Aleixandre, obra que también hemos consultado y citamos en este trabajo. Las diecisiete leyendas con sus años de publicación son las siguientes:

"El caudillo de las manos rojas" (1858); "La cruz del diablo" (1858); "La Creación" (1861); "La ajorca de oro" (1861); “El monte de las ánimas" (1861); "Los ojos verdes" (1861); "Maese Pérez el organista" (1861); "El rayo de luna" (1862); "Creed en Dios" (1862); "El Miserere" (1862); "El Cristo de la calavera" (1862); "El Gnomo" (1863); "La cueva de la mora" (1863); "La Promesa" (1863); "La corza blanca" (1863); "El beso" (1863) y por último, "La rosa de Pasión” (1864).

2 De acuerdo con Luis Cernuda, es "difícil separar su verso de su prosa, que fueron ambos prosa poética" (323). Distinguía Cernuda, implícitamente, en un estudio clásico sobre la prosa de Bécquer, dos maneras de manejar éstas con fines poéticas. De este último escribía Cernuda: "El poema en prosa, no se propone nada ajeno a su propia finalidad de expresar una emoción y experiencia poética" (La familia 40), añadiendo que debía ser necesariamente breve. "Como las Leyendas de Bécquer son, en ocasiones, largas, esto le obliga a seleccionar fragmentos dentro de aquellas que pudieran pertenecer con toda razón y sin duda posible a esta categoría lírica" (La familia 40). 


\section{CAPÍTULO III}

\section{EL PAISAJE EXÓTICO EN LAS LEYENDAS DEL CICLO NARRATIVO HINDÚ}

Adonde no alcanza, pues, ni la paleta del pintor con sus infinitos recursos, ¿cómo podrá llegar mi pluma sin más medios que la palabra, tan pobre, tan insuficiente para dar una idea de lo que es todo un efecto de líneas, de claroscuro, de combinación de colores..., de luz que hiere, de ruido que aturde, de vida, en fin, con sus múltiples manifestaciones, imposibles de sorprender con sus infinitos accidentes ni merced a la cámara fotográfica?

Desde mi celda, $\mathrm{V}$ Gustavo Adolfo Bécquer

Tres son las narraciones de tema indio escritas por Bécquer: "El caudillo de las manos rojas, tradición india"1; "La Creación, poema indio”; y "Apólogo". De las tres narraciones, sólo las dos primeras se consideran inequívocas leyendas, de acuerdo con la crítica. "Apólogo", sin embargo, no alcanza esta categoría. Rica Brown lo llama "esbozo de leyenda" (209), así como "una anécdota, con su tono, además, de cuento hablado" (210). En el prólogo a Narraciones, Pascual Izquierdo señala que “la mirada irónica no sólo está presente en el contenido general que ofrece este relato alegórico sobre la naturaleza humana, sino que se manifiesta en algunas expresiones 'inadecuadas"' (102). Así tenemos que, a la visión de "esbozo de leyenda" y "anécdota" de Brown, habría que añadir la de "relato alegórico" de Pascual Izquierdo. Por lo tanto, la hemos excluido de nuestro análisis. Sin embargo, en los tres relatos del llamado "ciclo narrativo hindú", Bécquer describe el mismo universo exótico, y nos presenta las mismas imágenes orientalizadas con las que 
construye su particular visión del Oriente. Se trata, sin embargo, de una visión "idealizada", mucho más próxima a las imágenes exóticas (re)creadas por algunos de los más importantes escritores románticos: Chateaubriand, Heine o Nerval, así como de la imagen estereotipada que de esa parte del mundo tenía los europeos, que de un Oriente, digamos, "real". Esto, desde luego, no disminuye en absoluto la concepción creadora de Bécquer, a pesar de las inexactitudes mitológicas y geográficas que observamos en estos textos, que quizás debamos interpretar como "licencias artísticas". En esto, como señala Rica Brown, "más de medio siglo antes que Rudyard Kipling, ya Bécquer había sentido el encanto de las leyendas indias y pensado interpretarlas para mayor gozo de la imaginación europea" (173).

Es sabido que con la llegada del Romanticismo se concretó, al menos en parte, el interés de los románticos por todo lo antiguo y exótico. De la variante de este exotismo surge el llamado "orientalismo romántico", que funde en una "construcción" todas las culturas situadas al este de Europa, de Asia, pero también del norte islámico de África. Por ello, el gusto e interés estético y académico de Occidente por lo oriental, responderá mucho más a las necesidades y anhelos románticos de la cultura europea, que a factores relacionados con la realidad de aquellos países, más o menos remotos. El Oriente es, de forma general, sinónimo de exotismo, y la India, el país más exótico de ese Oriente imaginado por los europeos, tal y como ejemplifican las múltiples representaciones literarias y artísticas decimonónicas. Un interés desmedido por la recóndita India, de la que no pudo sustraerse Bécquer, había permeado la creación literaria y pictórica de la época, sobre todo la británica, como potencia imperial dominante en esa parte del mundo, 
aunque toda Europa, en mayor o menor medida, se vio influida por este fenómeno. Ya desde comienzos del siglo XIX, y a partir de la presencia napoleónica en Egipto, Europa será testigo de significativos avances en el campo, no sólo de la egiptología, sino del estudio de las culturas del Oriente medio y el norte de África: Palestina, Túnez, Argelia y, sobre todo, Marruecos, como avalan los numerosos estudios de esas culturas llevados a cabo en el ámbito académico. La impronta árabe, sin embargo, tiene un peso cultural considerable en Europa, sobre todo en la península ibérica, si lo comparamos con las culturas asiáticas, geográficamente más distantes de España, como la cultura india o la de los países del lejano oriente, mucho más relacionadas con países como Gran Bretaña y Portugal.

Esta visión romántica del Oriente por parte de los europeos bascula entre la realidad y la ficción; es decir, se crea una realidad paralela, que llega a arraigarse con tal fuerza en el imaginario colectivo europeo, que muchos escritores y artistas se ven impelidos a viajar por los países considerados "exóticos" como parte del proceso de creación de sus obras. Como afirma Quinet, "[d]e pronto una amplia gama de pensadores, políticos y artistas adquirió una nueva conciencia de Oriente, desde China al Mediterráneo, debido en parte al descubrimiento y a la traducción de textos orientales del sánscrito, del farsi y del árabe" (Cit. por Said 71).

Por otra parte, el grand tour europeo, que dejó tantas huellas positivas en la España decimonónica, también le legó, a la luz de los estudios poscoloniales, una visión equívoca y adulterada del país, cristalizada a partir de los modelos "orientalizados" (en el sentido de "arabizados") andaluces, que fueron cultivados hasta la saciedad. Esta imagen típica y tópicamente romántica de bandoleros, 
toreros, majas y gitanos, eternamente medieval y morisca, imagen desvirtuada del país, debe su razón de ser a este interés de los románticos por las imágenes exóticas, de cierta manera desmedido y muchas veces superficial, cuando no artificial. Tanto es así, que el "orientalismo" creará, en palabras de María del Mar Villafranca Jiménez, "su propio universo estético regido por códigos exclusivos y convenciones epistemológicas que prescinde de la realidad tangible y características de los lugares que pretende evocar y estudiar" (16). Para Said, además,

"la lista de referencias, préstamos y transformaciones que se asociaba con la idea de Oriente es inmensa, pero en el fondo, lo que realmente realizaron los primeros orientalistas y lo que los no orientalistas de Occidente explotaron fue un modelo reducido de Oriente adaptado a la cultura reinante y dominante". (212)

Este fue el modelo seguido por Bécquer: La elaboración de una India que respondiera a sus exigencias teórico-artísticas; asunto ya definido, pues el punto de partida lo constituía la copiosa documentación reunida por Bécquer para la Historia. En ese sentido, se trataba de una India creada como "ilustración", como paisaje de fondo, a pesar del valor protagonista que puede llegar a alcanzar el paisaje --o algunos elementos aislados del mismo-- en las leyendas indias, pero, sobre todo, por sus valores plásticos; es decir como pintura exótica.

Conviene referirse, antes de continuar, a los significados del vocablo "exótico". De acuerdo con el diccionario de la RAE, significa, entre otras acepciones, "extranjero, peregrino, especialmente si procede de un país lejano". También, "extraño, chocante, extravagante". El vocablo exotismo, de relativa reciente 
aceptación, presenta diversos matices: "cualidad de lo exótico; tendencia a asimilar formas y estilos artísticos de un país o cultura distintos de los propios". En algunos escritores se manifiesta en el deseo de describir un país distinto, nuevos paisajes o modos de vida diferentes, ya sea apoyándose en experiencias propias o en conocimientos adquiridos en fuentes disímiles, de ahí que el paisaje sea una de las vertientes más intensas del orientalismo.

De acuerdo con la opinión de Francisco Lafarga, "se da también un exotismo exacto, realista. Es el de los viajeros cuando son escritores de talento: Flaubert, Chateaubriand, Loti. Hay en estos autores una búsqueda de sensaciones más intensas, de emociones más fuertes que las que podían experimentar en sus círculos habituales" (174). Tendríamos que agregar otros nombres: Gautier y Mérimée, entre otros. Los términos "exacto" y "realista" a los que alude Lafarge, habría que tomarlos, además, con cierta reserva, toda vez que es imposible obviar que las producciones de estos escritores reflejan el carácter eurocéntrico del orientalismo, pues ninguno de ellos pudo prescindir, en definitiva, de su propia cultura. Toda visión europea de ese Oriente queda, pues, subordinada, a su particular forma de "ver" y "entender" esas culturas, desde una perspectiva esencialmente europea, definida y acotada por europeos y, por tanto, cerrada y acabada. Esto es así, porque la crítica cultural occidental, en general, propone y promueve un discurso "occidentalista" sobre el Oriente, que evocaba, sobre todo en los siglos XVIII y XIX, todo un complejo universo de exotismo, fantasía y erotismo, salpicado de prejuicios hacia "el otro". Al respecto, Said asumió una posición políticamente historicista, “deconstruyó ‘Oriente’ para reconstruir el discurso que acerca de él, erróneamente, 
han producido generaciones de artistas, viajeros, misioneros, académicos y autores occidentales" (El-Outmani 1). Para Said, la visión eurocéntrica del Oriente es, desde una perspectiva histórico-cultural, una fabricación de la fantasía occidental que ha mistificado lo oriental.

¿Cómo acercarnos, entonces, a los cuadros becquerianos sobre la India? La construcción del Oriente de Bécquer es una creación de taller --una fabricación, para usar las palabras de Said--, en cuanto a la detallada labor de investigación llevada a cabo, con el propósito de lograr un escenario creíble, pero desde su visión europeísta; por lo tanto, sólo podríamos destacar, por un lado, el realismo exótico "orientalizado" de los contenidos, y, por otro --si fuera el caso poder compararlas-las diferencias estéticas con otros "cuadros" orientalistas, sobre todo los de aquellos escritores y artistas, cuya experiencia de viaje pudo haberles otorgado una visión más cercana a la India, aunque igualmente imperfecta desde el punto de vista ideológico. Este aspecto, desde la perspectiva de Said, siempre se pretende esconder en el análisis occidental. No cabe, pues, la posibilidad de este análisis a la luz del discurso ideologizado de Said, por cuanto escapa a nuestro propósito en este trabajo, pero sí son válidas algunas ideas de lo que él llamó "fase textual"; esto es, la aceptación --como lo hizo Bécquer sin cuestionarla-- de esta visión europea del Oriente.

En el caso de Bécquer y las leyendas indias, debemos destacar, una vez más, su enorme capacidad artística para seleccionar, añadir y (re)elaborar literariamente lo que ve, pero, en este caso, mucho más lo que imagina, de ahí que su (re)creación del paisaje indio, de los ambientes y personajes de estos relatos responda, en su 
caso, mucho más a un proceso artístico creativo o de "(re)interpretación arqueológica" (un término que utilizaré en este trabajo) que a una reproducción de la realidad india, con las restricciones que el término "realidad" conlleva. El lenguaje utilizado por Bécquer no es narrativo ni tampoco descriptivo, en su sentido, digamos, tradicional, sino que busca construir un discurso visual mediante la elaboración de imágenes dotadas de una gran plasticidad y colorido, pues en Bécquer toda descripción es, ante todo, un acto de (re)creación artística. No podemos obviar, por otro lado, que la écfrasis es "representación", pero también es "interpretación" o "recreación"; de ahí que las ekphrasein o écfrasis, construidas por Bécquer en estas dos leyendas indias, nos remiten, aunque de forma fragmentada en muchos casos, pero aun así plenamente identificable, al estilo de algunos artistas plásticos por los que Bécquer siente una particular atracción. Estamos, por otra parte, ante écfrasis referenciales-genéricas --también llamadas atributivas o imperfectas por otros críticos-- a tenor de las clasificaciones esbozadas por Luz Aurora Pimentel, por cuanto nos refieren a ciertos elementos o rasgos característicos de un artista, más que a la referencia concreta del objeto plástico o visual creado por éste. En ese sentido, se acerca también a la écfrasis literaria de Michel Rifaterre, tal y como lo hemos explicado con anterioridad.

\section{III.1. Fuentes del ciclo narrativo hindú.}

Parece ser que en el siglo XVIII los españoles viajaron mucho menos que otros europeos, de acuerdo con las estadísticas de la época, y todavía fueron menos los que dejaron por escrito sus experiencias e impresiones. Eso hace que la literatura de viajes escrita por españoles sea muy limitada, aun cuando puedan 
quedar textos por estudiar y hasta por descubrir. De los relatos de viajes, los más conocidos se centran en otros países europeos: Francia, Inglaterra e Italia, sobre todo. De los viajes a las regiones llamadas "exóticas" existen pocas referencias, y casi siempre a países musulmanes, sobre todo a Marruecos -piénsese en $\underline{\text { Cartas }}$ Marruecas de José de Cadalso, por ejemplo-- país con el que se intentaba mantener buenas relaciones de vecindad. Los periódicos de la época publicaban noticias y comentarios de países lejanos, usualmente a través de textos franceses traducidos, pero en muchos casos, ya fuese por su contenido crítico o erótico, estos textos se publicaban mutilados o alterados a tenor de la censura impuesta por la Inquisición.

En el catálogo preparado por Fernández Montesinos podemos hallar títulos representativos; algunos de ellos de aparición tardía en español: Las mil y una noches de Antoine Galland (París, 1838); las Cartas persas de Montesquieu, por Machena (Nîmes, 1818); Gonzalo de Córdoba o la conquista de Granada de Florian, por Juan López de Peñalver (Madrid, 1794); Viajes de Antenorpor Grecia y Asia de Lantier (Madrid, 1802); Pablo y Virginia de Bernardin de Saint-Pierre, por José Miguel de Alea (Madrid, 1798); y El inglés en la India o La cabaña indiana ${ }^{2}$ del mismo autor (Salamanca, 1803), entre otras. En la mayoría de los casos se acompañaban de grabados e ilustraciones realizados por reconocidos artistas que completaban visualmente la lectura de estas noticias. Desde entonces, el exotismo se extenderá a las artes plásticas, la música, las artes decorativas, la filosofía y, en general, a todas las manifestaciones culturales.

La India de los relatos de Bécquer es, sobre todo, una "construcción" artístico-literaria, un paisaje textual, apoyado documentalmente, eso sí, en sus 
lecturas e investigaciones sobre el tema, que incluyó el análisis detallado de grabados y reproducciones de obras de arte. Es decir, hubo una fuente preliminar, llamémosla gráfica, además de la temática --lo que no excluye cierta libertad interpretativa--, ya que en su proyecto artístico-religioso de la historia de los templos españoles se contemplaba el acompañamiento de las descripciones textuales con ilustraciones apropiadas, de forma tal que el lector completase su visión de los templos mediante detallados grabados sobre los mismos.

Bécquer que, como es sabido, poseía "un talento artístico profundo y puro" (35), tal y como avala Rica Brown, llevó a cabo un exhaustivo trabajo de documentación artística para poder cumplir con su magno proyecto de la Historia. Es más, en consecuencia con su forma de trabajar --de la que ya hemos dado varios ejemplos concretos-- los apuntes o dibujos de que se vale Bécquer, así como la consulta detallada del material gráfico disponible, pudo presidir en muchos casos, cuando no simultanear, a la consulta y revisión temáticas. En todo caso, como describe detalladamente en "Tres fechas", la preparación del material gráfico, ya fuese mediante sus propios dibujos o de otros artistas, o bien agrupando el material de fuentes disímiles, era el punto de partida vital al escribir, tal y como prueban, además, otros textos en los que aborda su forma de trabajar. Se sabe, por otra parte, que Bécquer consultaba periódicamente al pintor Casado de Alisal sobre los aspectos artísticos de la Historia de los templos de España. En los primeros grabados para este proyecto, observamos la firma de este pintor como prueba de su contribución. Es sabido, además, que Bécquer y Casado de Alisal mantenían una estrecha relación, como lo prueba el hecho de que debemos a este artista la primera 
publicación de las obras de Bécquer, así como uno de los mejores apuntes que hiciera de éste en su lecho de muerte. De igual manera, su hermano Valeriano no queda excluido de ese necesario --y obligado-- diálogo artístico, tal y como era ya habitual entre hermanos que mantenían una estrecha colaboración artísticoliteraria, lo que está ampliamente documentado.

Por otro lado, Bécquer, como sabemos a través de sus biógrafos, no estuvo jamás en la India ni en ningún otro país del Oriente, ni siquiera en Marruecos. De hecho, viajó poco, y siempre dentro de España. Su periplo geográfico fue muy limitado y se refleja en los escenarios de las leyendas. Es probable que las restricciones económicas que padecía y la enfermedad crónica que lo afectaba por etapas, contribuyeran a estas limitaciones, aunque ciertamente no redujeron sus capacidades de lectura e investigación. Sus narraciones indias se deben, con toda probabilidad, a las lecturas y consultas gráficas preliminares que llevó a cabo para la preparación de la Historia de los templos de España, o bien de antes. Regueiro Salgado lo confirma: "En el caso de la cultura de la India, los conocimientos del poeta vendrían, únicamente, de los libros" (180). Además, en los tiempos que vivió con su madrina, Manuela Monnehay ${ }^{3}$, mujer de cierta cultura que abrigó a su ahijado a la muerte de su madre, Bécquer fue un ávido lector de la abundante y selecta biblioteca de ésta. Julio Nombela, que entre 1853 y 1860 era su íntimo amigo, asegura que Bécquer "vivió dos años sin salir de la casa de su protectora... engolfado en la lectura, porque no había dejado de leer ni uno solo de los libros que poseía su madrina" (212). También recuerda Nombela algunos de los títulos de estos libros, por las discusiones que tuvo con Bécquer sobre los mismos: "En su mayoría eran 
novelas de Chateaubriand, de Madame de Staël, de D'Arlincourt, de Jorge [sic] Sand ${ }^{4}$ y de Balzac; poesías de Lord Byron, de M. [sic] Musset ${ }^{5}$, Víctor Hugo, Lamartine, Espronceda; los fantásticos cuentos de Hoffmann" (212).

No descartamos que en la biblioteca de doña Manuela existieran algunas obras o relatos de viajes de tema hindú, muy populares en la época, pues estas

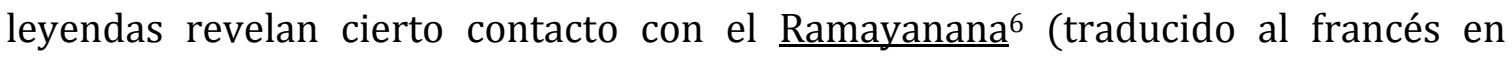
1854), así como la lectura detallada de La chaumière indienne (La cabaña indiana), de Bernardin de Saint-Pierre, en su versión original en francés (1790), cuyos ecos intertextualizados se perciben con asombrosa claridad en "El caudillo". Tampoco excluimos la visita de Bécquer a museos y salas de exposiciones de arte indio, tan en boga en la época, como parte del enriquecimiento visual del artista comprometido con un proyecto artístico de gran magnitud, que demandaba una exhaustiva preparación gráfica y artística con vistas a obtener la mayor fidelidad de los templos y monumentos descritos y reproducidos gráficamente.

En L'Inde, Théophile Gautier destaca que resulta comprensible el interés desmedido por la India de muchos de los escritores europeos, muchas veces como reflejo de su interés en lo exótico y en no pocos casos por sus experiencias de vida, ya que fueron infatigables viajeros:

Depuis notre enfance, nous avons regardé avec une curiosité avide et superstitieuse toutes les gravures, tous les dessins, tous les recueils qui se rapportent à cette mystérieuse contrée ou ont pris naissance, à des époques qui se perdent dans la nuit des temps et qui déconcertent toute chronologie, les théogonies, les civilizations, les sciences, les 
arts, les langues, dont les nôtres ne sont que les effluves et les dégénérescences. (306-7)

Resulta muy esclarecedor, viniendo de un escritor tan sumamente apegado a lo visual como Gautier, las citas referentes a todos los grabados y a todos los dibujos, como fuentes de interés, de una "ávida curiosidad" por lo plástico. No resulta, pues, extraño que igual atractivo haya sentido Bécquer. De hecho, la propia mención de la India en la historia de los templos, atestigua ya su interés en sus manifestaciones artísticas a través de sus templos.

Es, precisamente, en su obra sobre la Historia de los templos españoles y de todas las religiones del hombre, donde encontramos las primeras alusiones a la India. Era parte de una actitud general, que valoraba lo primitivo histórico, lingüístico y artístico con un particular interés. Así, en "El Cristo de la luz", Bécquer se refiere a la India en estos términos:

La India, con su atmósfera de fuego, su vegetación poderosa y sus imaginaciones ardientes, alimentadas por una religión toda maravillas [sic] y ritos emblemáticos, ahuecó los montes para tallar en su seno las subterráneas pagodas de sus dioses.

La extraña y salvaje poesía de los Vedas parece que toma formas y vive, cuando a la moribunda luz que se abre paso a través de las grutas sagradas, se ven desfilar, confundiéndose entre las sombras de sus muros, las silenciosas procesiones de elefantes, guiados por esos deformes genios que despliegan sus triples miembros en semicírculo, como las plumas de un quita sol. (Obras completas 993-4) 
Hay ya, en esta cita, referencias muy concretas a imágenes óptico-lumínicas de "fuego" y de "vegetación", de "luz" y de "sombras", así como a la "talla" de pagodas y al conjunto escultórico de elefantes --propias de un artista--que anticipan la prosa plástica de las Leyendas. Al respecto, Berenguer Carisomo destaca, con relación a los temas escogidos por Bécquer, que "[p]ara que el fondo sirva de incentivo al goce de la forma, elige temas exóticos, ricos de color, pródigos en materiales plásticos, y se detiene en los detalles, en la composición cromática" (42).

No hay duda, por su interés artístico, que tanto en "El caudillo", como en "La creación", la India se presenta ante Bécquer como una tierra llena de contrastes, cuyas infinitas posibilidades cromáticas, así como el juego de luces de sus variados paisajes, propician el ejercicio de su probada paleta de pintor. El descubrimiento de la cultura india --aun con las limitaciones que entraña una "fabricación" ajena a la realidad-- y de la riqueza de sus artistas, fue muy importante para Bécquer, ya que le permitió, bajo el velo de lo exótico, desplegar una prosa rica en contrastes y abundante en cromatismos, algo que lo tentaba desde siempre.

A los efectos cronológicos, se ha dado en relacionar este exotismo indio de Bécquer con el naciente movimiento simbolista y decadente. Al respecto, Candido Panebianco ha destacado en su obra L'esotismo indiano di Gustavo Adolfo Bécquer lo siguiente:

Scritta in anni in cui l'Orientalismo abbandonava la via tracciata dal Romanticismo, per volgersi con Leconte de Lisle ad experienze di tipo decadente, questa 'Tradición india', come amò definirla l'autore, resta, almeno nella tematica, fedele alla fase teogónica ed epica del 
movimiento, ancora parecchio lontana dal carattere morboso che esso assumerà nella Francia fin de siècle. (13)

Jan Gonda, en Le religione dell India, señala que "[i]n tutte e tre le leyendas infatti s'impone la celebre Trimurti Brahama-Vishnu-Shiva, que nell'Induismo classico rappresenta la fenomenología dell'essere: il principio creatore (Brahama), quello conservatore (Vishnu) e quello distruttore (Shiva)" (447).

Las circunstancias de la publicación de "El caudillo de las manos rojas" hacen difícil una concreción de su fecha de creación. Habría que situarla, probablemente, entre finales de 1867 y principios de 1858, habida cuenta de las contradictorias informaciones de que disponemos ${ }^{7}$. Se trata, curiosamente, de fechas relativamente tempranas para España en comparación con otros países, donde este interés aparece mucho más tardíamente, quizás con la sola excepción de Francia. Aun así, el tema indio no alcanzará cierto relieve en este país hasta el primer tercio del siglo XIX, cuando aparecen, hacia 1825, algunos trabajos importantes de Chézy, de su discípulo Eugène Bournouf, así como de Michel Langlois, Eugénie Montegut, Edgar Quinet, Abel F. Villemain y Théodore M. Pavie, entre otros autores. No debe descartarse la posibilidad de que Bécquer hubiese leído algunas de estas obras. La India también facilitaba la introducción de un nuevo universo simbólico, algo que no debió pasar inadvertido para Bécquer --un escritor que también se cuenta entre los pre-simbolistas--, de ahí que más de un crítico suele afirmar que con los comienzos del exotismo hindú se suele datar el origen del simbolismo. Como señala Rubén Benítez, "en la selva de símbolos de Baudelaire hay remembranzas de la selva indiana" (110). 
El crítico Rubén Benítez fue quizás el primero en advertir ciertas similitudes entre "El caudillo" y La chaumiére indienne de Bernardin de Saint-Pierre, una novela muy leída en toda la Europa decimonónica. En ella, según el criterio de Benítez, "se fijan por primera vez ciertos nombres geográficos y costumbres típicas de la India que luego se repetirán frecuentemente en la literatura y el periodismo" (112).No hay duda de que la novela de Saint-Pierre marcó un hito en la visión que se tenía en Europa y otros lugares sobre la India. De hecho, es una obra importante, incluso vital para el propio Bécquer, pero no creo que deba afirmarse categóricamente que "por primera vez" aparecen en ella ciertos nombres y costumbres indias, habida cuenta de las diversas obras y artículos que ya se habían publicado sobre el tema, o las propias traducciones de textos indios que ya circulaban en mayor o menor medida desde finales del siglo XVIII, a lo cual nos hemos referido antes.

En 1837, otro gran admirador y divulgador del exotismo hindú, Théophile Gautier, da a conocer en Le Figaro su novela L'Eldorado (publicada al año siguiente

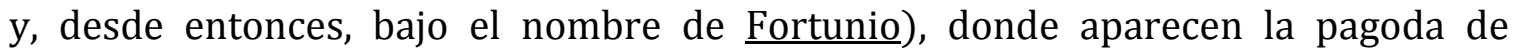
Jaganata y las danzas de las bayaderas, y en donde el personaje Tippoo-Saib parece ser, a juicio de Benítez, el modelo del "Tippot-Dheli de Bécquer" (112). En 1856, Gautier publica Avatar, a manera de folletines, en el Moniteur Universel, entre otras obras de contenido indio. Así, en su ya mencionada obra L'Inde, declara: “Voir l'Inde est un désir qui nous travaille depuis notre plus tendre enfance" (242). Y en el propio año en que se publica "El caudillo", en 1858, Gautier estrena en la Ópera de

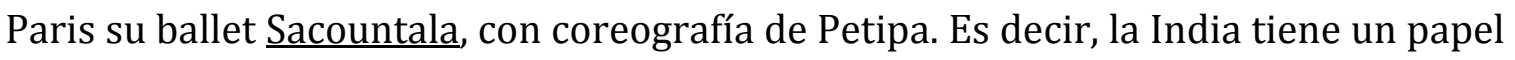
muy relevante en el imaginario exótico de Gautier, gran lector, por otra parte, de 
textos indios o sobre la India. Resulta, además, coincidente el hecho de que, al igual que Bécquer, el interés primario de Gautier --un probado referente literario para Bécquer-- haya sido la pintura, de ahí la abundante literatura crítica e historiográfica sobre las artes de su autoría. Su prosa, como la de Bécquer, presenta características muy similares en cuanto a la valoración privilegiada de lo plástico como elemento de expresión, así como al papel del color, de la luz y de la línea, entre otros elementos compositivos del cuadro, en su producción literaria.

También es muy probable que en su labor como periodista Bécquer haya tenido contacto con obras o artículos periodísticos sobre la India y quizás algunos libros de viajeros, como el libro del Abbé o Abate J. A. Dubois: Descriptionof the Character, Manners and Customs of the People of India and of their Institutions, Religious and Civil, publicado en inglés en 1817 y más tarde traducido a su lengua original, el francés. Una sinopsis de la obra, además, fue traducida al español, en 1842, bajo el nombre de Costumbres, instituciones y ceremonias de los pueblos de la India oriental. En esta obra, la haya consultado Bécquer en una lengua u otra, se describen algunas escenas que bien pudieron servirle para su relato, como el sati o sacrificio de la viuda en la pira funeraria del esposo, una ceremonia entonces ignorada en Europa. Bécquer menciona a Sianah, la protagonista de la leyenda, como la primera viuda india que se arroja a la pira. Pero el libro del Abbé Dubois, sin embargo, no se publicó en su forma más completa, al menos con sus cinco apéndices, hasta 1897. En el apéndice quinto aparece la historia del ídolo del Jaganata "tal y como aparece en el relato de Bécquer" (114), de acuerdo con Benítez. Debemos, entonces, suponer que Bécquer tuvo conocimiento de estos hechos a 
través de otros textos similares o de las versiones simplificadas de la obra del Abbé Dubois, como la versión en español de 1842, de lo cual no hay constancia. Es muy posible, también, que Bécquer tuviera acceso a cualquiera de los trabajos ${ }^{8}$ aquí mencionados o a otros de similar contenido desde mucho antes de escribir sus leyendas del ciclo hindú.

Por otra parte, fiel a su ideal romántico, Bécquer no ve la realidad india como "es", sino que la interpreta en clave de deseos; la (re)construye, la manipula, en fin, para que se adecúe a sus deseos y propósitos, sobre todo a su interés plástico. Por lo tanto, su visión está muy falsificada, y "ve" lo que quiere "ver". Esta mixtificación -cabe mencionarlo-- también está determinada, en palabras de Said, por "el estilo normativo de la prosa europea" (230). Por otro lado, puesto que la visión de Bécquer se apoyaba en traducciones o textos europeos --es decir, ya filtrados por el tamiz eurocéntrico-- la India "orientalizada" propuesta por Bécquer es, sobre todo, el resultado de una edición, de una supresión --si algo quedaba-- de todo aquello que podía resultar perturbador a la sensibilidad europea, y a la suya propia.

\section{III.2. Análisis de las leyendas del ciclo narrativo hindú.}

En términos pictóricos, la India que nos pinta Bécquer, tanto en "El Cristo de la luz" como en sus leyendas del ciclo narrativo hindú, es el producto de la recreación de una tierra llena de color --sobre todo de tonos brillantes--y de una intensa luz, propicia a crear efectos dramáticos de luces y sombras, de claroscuro. No en vano Bécquer abre y cierra muchos de sus cuadros pictórico-descriptivos -sus écfrasis-- mediante auroras y crepúsculos. También alude a escenas del mediodía por la intensa luminosidad pictórica con que podía iluminar algunas 
escenas. Bécquer, de cierta manera, se vale de los tres elementos esenciales del arte indio: los sentidos, las emociones y el espíritu, para ambientar y transformar el espacio pictórico descrito en sus narraciones. El arte indio, que es principalmente una manifestación religiosa, debe ser comprendido e interpretado en el contexto de las necesidades ideológicas, estéticas y rituales de su civilización. Así, todos los elementos que conforman el arte indio, tales como la forma del templo, los contornos de los cuerpos, el color, la luz, la sombra, la composición y el volumen, simbolizan el misterio que resuelve algunas dicotomías esenciales: vida y muerte, temporalidad y eternidad. En esto, el arte indio no difiere del cristiano. Sin duda, Bécquer estudió mucho estos aspectos de la cultura india.

Pascual Izquierdo afirma que "El caudillo" puede ser entendido como "un largo poema en prosa compuesto de innumerables pequeños poemas" (45). Esto, desde el punto de vista lírico; pero pueden verse, además --o sobre todo--como cuadros de pequeño formato o "tableautins" ${ }^{9}$, desde el punto de vista plástico. En cuanto a su estructura, Bécquer lo divide en siete capítulos, subdivididos a su vez en estrofas o cantos en los que nos pinta un sinnúmero de expresivos cuadros de ambientación sensorial, que son, a la vez, miembros compositivos de un lienzo mucho mayor.

Las descripciones ecfrásticas, sin embargo, o agrupan varias estrofas, o bien se circunscriben a una misma estrofa, o sólo ocupan parte de la misma. Pero en todos los casos, Bécquer manifiesta, en su plena capacidad de artista, un dominio riguroso en la pintura y musicalidad de los escenarios, los ambientes y los personajes. Su prosa plástica incluye percepciones visuales, auditivas, olfativas, 
táctiles, visionarias y oníricas, o en una combinación de algunas de ellas. Es lo que llamaremos aquí "construcción ecfrástica multisensorial".

En "La Creación", subtitulado "Poema indio" (1861), además del cuidado en la estructura literaria y de la preocupación estilística, habría que subrayar el movimiento que le imparte a las escenas y el papel destacado del elemento fantasioso. De acuerdo con Berenguer Carisomo, "una riqueza de fantasía en la composición que solamente podría transcribir hoy, con fidelidad, el milagroso hallazgo del dibujo animado" (31). "La Creación" tiene la misma forma que "El caudillo", pero el canto, divido en diecinueve estrofas, tiene sus propias características, aunque Bécquer utiliza algunos recursos, que veremos más adelante en "El caudillo", y que se repiten, además, en algunas rimas. "La Creación" es, al decir de Pageard, un apólogo ameno, "de tono ligero, pero encubre un pensamiento pesimista" (229). Es muy posible que Bécquer lo haya escrito, al igual que "El caudillo", como apunta el propio Pageard, "entre 1857 y 1858" (229), dada la coincidencia temática y, muy posiblemente, informativa.

Comencemos por destacar que "El caudillo" es una leyenda mucho más extensa que cualquiera de las escritas por Bécquer. Desde el primer canto --para algunos críticos, estrofas-- al cuarto, Bécquer nos dibuja el crepúsculo y el anochecer: "El sol ha desaparecido tras las cimas del Jabwi, y la sombra de esta montaña envuelve con un velo de crespón a la perla de las ciudades de Orisa, a la gentil Kattak, que duerme a sus pies, entre los bosques de canela y sicomoros, semejante a una paloma que descansa sobre un nido de flores" (Canto I 106). El segundo canto continúa la écfrasis anterior al dilatar con más detalles plásticos el 
anochecer: "El día que muere y la noche que nace luchan un momento, mientras la azulada niebla del crepúsculo tiende sus alas diáfanas sobre los valles, robando el color y las formas a los objetos, que parecen vacilar agitados por el soplo de un espíritu" (Canto II 106) ${ }^{10}$.

En estos dos primeros cantos prevalecen las percepciones visuales. Bécquer ha querido pintarnos un atardecer, porque refleja la pérdida de la luz y del color, es decir, las sombras, que son el preludio pictórico-emocional necesario a la aparición de Pulo-Dheli, en el canto IV. Aquí concurren el velo de crespón y una azulada niebla que parecen envolver el paisaje, difuminar los contornos y oscurecer la paleta, dentro de un vocabulario netamente pictórico. Habría que subrayar, además, los efectos ilusionistas y sensuales bajo un canon plenamente literario. El tratamiento, sin llegar a llamarlo impresionista, se acerca a la pincelada suelta y al juego de luces de un Fortuny, que ya para esa fecha era conocido por sus acuarelas de plasmación instantánea y sus composiciones de temática oriental, aunque concurren también en esta "pintura" elementos de los paisajes de Lorrain en los que la luz juega un papel unificador y hasta poético. Aquí Bécquer parece jugar con lo efímero del anochecer, utilizando una cierta economía de recursos plásticos, como si se tratara de un trabajo a la acuarela, trabajo que es necesario realizar con gran rapidez y trazos muy seguros. La técnica transparente de la acuarela --utilizada por Bécquer en algunos de sus dibujos--implica la superposición de lavados finos y se basa en la blancura del papel para obtener sus efectos y los toques de luz. A medida que se superponen más lavados, el color se hace más profundo. La acuarela, de la que los DomínguezBécquer fueron grandes maestros, ofrece muchas posibilidades: la técnica del 
lavado permite crear degradados o lavados uniformes, incluso superposición de colores, pero, sobre todo, permite abordar cromáticamente los temas de forma rápida. El efecto de "niebla azulada" o "velo" envolvente que utiliza Bécquer --como elemento cromático, atmosférico y luminoso por excelencia-- en esta descripción ecfrástica nos remite a la técnica pictórica de la acuarela.

En el canto III dominan las percepciones auditivas con la llegada de la noche, que constituyen un elemento importante del cuadro descrito, pues sirven de contrapunto a la imagen, si se quiere, pero desde el punto de vista de la percepción, esto es, de lo que percibimos en tanto que lectores-espectadores. Estas percepciones auditivas son, en realidad, "imágenes sonoras" o "imágenes acústicas" --términos acuñados por Ferdinand de Saussure en su obra Memoria sobre el sistema primitivo delas vocales indoeuropeas (1878)-- puesto que se trata de las imágenes mentales que a cada uno de nosotros le sobreviene ante un estímulo sonoro. El teórico Herbert Marshall McLuhan, en su teoría de la percepción, afirma que "la imagen sonora necesita ser fortalecida por otros sentidos. No porque la imagen sonora sea débil, sino porque la percepción humana tiene gran dependencia de la percepción visual y el sentido del oído necesita que la vista confirme lo que ha oído" (52). Basado en estas apreciaciones, utilizaremos "las imágenes sonoras" como complemento del cuadro ecfrástico al considerar que aportan una mayor riqueza visual al texto. En esto contexto, estas percepciones auditivas becquerianas pasarían a llamarse "recursos para-ecfrásticos".

Bécquer, el músico ${ }^{11}$, nos presenta en el canto III "los mil ruidos misteriosos", el "himno a la divinidad", "el murmullo del Jawkior", que produce "un canto dulce, 
vago y perdido", que Bécquer compara con "la improvisación de una bayadera", bailadora y cantadora india que intervenía, sobre todo, en ceremonias religiosas. Aquí Bécquer se coloca en situación de "oyente" externo de la musicalidad romántica que va cultivando poco a poco. En este escenario de tonos apagados, grises y azulados, de indiscutible atmósfera pictórica --el contraluz típicamente lorenés--Bécquer nos presenta al personaje de Pulo-Dheli (cantos IV y V), coloreado en tonos brillantes, lo que acentúa el contraste: Éste adorna sus cabellos "con la roja cola del ave de los dioses indios" (107), cuelga "a su cuello la tortuga de oro" (107), suspende "su puñal de mango de ágata de amarillo schal" [sic] (107).

En esta pintura del personaje de Pulo-Dheli, de vivos colores primarios, Bécquer nos anticipa algunos elementos característicos de la pintura prerrafaelista que desarrollará en otras leyendas, en cuanto a la gran vivacidad del colorido y el realismo exacerbado de las descripciones, pues las ropas reflejan la luz por el brillo de sus colores y tejidos. Con ello, Bécquer pretendía recrearla naturaleza lo más exactamente posible a un cuadro ideal, así como los personajes, a los que otorga una gran libertad en las poses, como era característico de los pintores prerrafaelistas. Bécquer, además, nos traslada algunas técnicas de la pintura de paisaje de Lorrain, haciendo que enfoquemos nuestra atención en el asunto descrito y desde el ángulo deseado, apoyándose en estos efectos atmosféricos y lumínicos, totalmente verosímiles. Todo ello acompañado por apropiadas referencias religiosas, literarias y poéticas, como corresponde a su estilo: "rayo de las batallas y hermano de TippotDheli, magnífico rey de Orisa, señor de señores, sombra de Dios e hijo de los astros luminosos" (107). Sin embargo, todo ello ha sido abordado por Bécquer con entera 
libertad en la ejecución y desde una visión muy personal de un Oriente reconstruido de acuerdo con sus propósitos estéticos.

Debemos destacar otros elementos pictóricos en esta breve descripción ecfrástica que nos remiten, una vez más, a la luz y a la sombra, opuestos en ese diálogo de luces: "rayo" e "hijo de los astros luminosos" y, por otro lado, "sombra de Dios". Asimismo, las referencias temporales al amanecer y al mediodía, en tanto que pinceladas de luz, y al anochecer, como expresión de la sombra y, por consiguiente, de la ausencia de luz y color, se suceden a lo largo de "El caudillo". Ya en la Historia, específicamente en la sección dedicada a la basílica de Santa Leocadia, a la que hemos aludido con anterioridad, Bécquer "nos muestra" que "cuanto se ofrecía a nuestros ojos formaba un conjunto pintoresco; pero diríase, al contemplarlo, que sobre aquel paisaje había extendido el otoño ese velo de niebla azulado y

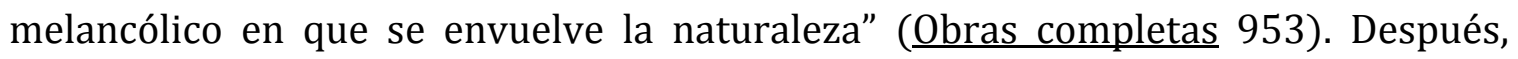
siguiendo lo que ya hemos mencionado como un recurso típicamente becqueriano, agrega que ese paisaje "es imposible de expresar con palabras", para luego establecer la conexión referencial con un artista que se hace presente en las leyendas indias. Así, nos dice: "Claudio Lorena en algunos de sus maravillosos paisajes, ha logrado sorprender su secreto a la naturaleza y ha reproducido ese último adiós del día con todo el misterio, con toda la indefinible vaguedad que lo

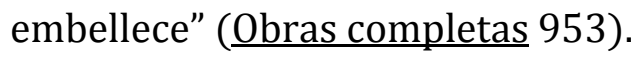

El pintor Claude Lorrain, o en su versión castellanizada de Claudio Lorena, que había reflejado en su obra un nuevo concepto en la elaboración del paisaje, llamado "ideal", de acuerdo con la clasificación del paisaje esbozada por Kenneth 
Clark, fue el referente pictórico del que se vale Bécquer, cuya concepción del mundo idealizado de la naturaleza y de su propio mundo interior están en abierta sintonía con el artista francés. Esta forma loreniana de tratar el paisaje --sobre todo el uso de la luz como elemento unificador del cuadro--, que Bécquer intermedializa o intertextualiza en esta leyenda, le otorga un carácter mucho más elaborado e intelectual y se convierte en el principal objeto dela creación artística, de la plasmación de su concepción del mundo, y en el intérprete de su poesía, que es evocadora de un espacio ideal.

Uno de los aspectos más destacados en la obra de Lorrain, que Bécquer supo asimilar magistralmente, es el tratamiento de la luz, a la que otorga una importancia singular al concebir el cuadro. Sin embargo, no estamos ante una luz metafísica, sino natural, de efectos observados en la naturaleza real, aunque traducidos y combinados con su sello personal.

Por otro lado, la luz le sirve a Bécquer, no sólo como base de la composición ecfrástica, sino también para crear el espacio y el tiempo, con los que articula los personajes --o figuras--, las masas arquitectónicas de los templos, así como los elementos de la naturaleza. Si volvemos a los cantos I y II, observaremos que la luz, o la ausencia de ella, domina el cuadro: el sol ha desparecido tras el monte Jabwi, una creación artística de Bécquer, sin duda, ya que no ha podido ser confirmada la existencia de este monte en la topografía india. Sin embargo, a los efectos de la pintura de paisaje, le resulta conveniente incluirlo como elemento compositivo del cuadro y como parte de su reorganización espacial, pues es una actividad propia del Bécquer-pintor. Así, el ocultamiento del sol tras "el monte" propicia la atmósfera 
deseada; esto es, las sombras o tonos umbrosos que cubren la ciudad de Kattak, entre los bosques de la región de Orisa.

En relación con el elemento fantástico de estos relatos, debemos señalar que Bécquer presenta éste como "natural", y la imagen que percibe el lector-espectador debe asumirla como "representación" de esa India "pictorializada", en abierta correspondencia con lo "natural o real". De esta forma, el relato fantástico queda subordinado a los elementos "realistas" de la composición. Debemos entender, sin embargo, a partir de Panofsky, Gombrich y Armheim, entre otros críticos del arte y de la cultura, que el significado de tales "realismos" y "realidades" es relativo; incluso, desde una perspectiva ideológica. En líneas generales, el interés de estos críticos se centraba en un acercamiento a la imagen que cambiaba, de forma sustancial, el propósito del análisis de la misma. Esto es así, porque les daban a las condiciones formales y estéticas de la imagen un valor relativo y se enfocaban mucho más en los aspectos internos de la misma. Así, sobre estos aspectos, esos críticos pensaban que poseían un valor mucho más amplio y específico que las muestras de un determinado modo de fijación pictórica de la realidad, pudiendo pasar por alto el modelo sensible y liberándose por completo de la impresión de lo "realmente" perceptible.

En el canto VII, Bécquer nos anticipa la aparición de Siannah, recurriendo a un esquema de invitación que es uno de sus recursos más utilizados, dirigiéndose a los lectores como si fueran espectadores de una experiencia sensorial: “Oís las hojas suspirar bajo la leve planta de una virgen? ¿Veis flotar entre las sombras... su diáfano schal [sic] y las orlas de su blanca túnica? ¿Percibís la fragancia que la 
precede como la mensajera de un genio? Esperad y la contemplaréis al primer rayo de la solitaria viajera de la noche" (108). De nuevo la luz, la débil luz de la luna, le otorga un nuevo sentido luminoso, melancólico hasta cierto punto, al paisaje "multisensorial", en sintonía con el gusto posromántico de franca inspiración loreniana. Este envolver el paisaje en una tenue luz, ya sea la del amanecer o del crepúsculo, pero todavía más en las escenas en que prevalece la luz lunar, difumina el dibujo e incrementa el desvanecimiento del color. Es lo que, técnicamente, se denomina "esfumado". De forma coincidente, la visión pictórica oriental buscaba crear con esta "vaporosidad" --otro término al uso-- en las atmósferas, un efecto de profundidad en el paisaje, que pudo haberle llegado a Bécquer, no sólo a través de Lorrain, sino, además, a través de las reproducciones del arte indio que consultó para su preparación de la Historia, como ya hemos señalado. Además, en el lenguaje del arte indio --y en otras culturas orientales-- se insiste en el nacimiento y puesta de sol, referidas a los puntos cardinales de oriente y occidente, como metáforas del nacimiento y de la muerte.

De la misma forma, en el lenguaje paisajístico de Lorrain, cuando la fuente de luz aparece a la derecha, es decir, el occidente, los colores empleados reflejan las puestas de sol y momentos del atardecer, esto es, tonalidades que van del rosapurpúreo--el rosicler-- y del naranja a colores más fríos, según avanza el anochecer. Por el contrario, cuando la fuente de luz se sitúa a la izquierda, esto es, al oriente, aparecen al comienzo tonalidades más frías, más cercanas a la noche, representativas del amanecer, que, según avanza éste, van confiriendo al paisaje tonalidades más cálidas. Con estos pares o dualidades interpretativas, y con su 
lectura de izquierda (amanecer) a derecha (atardecer), Lorrain quería transmitir la idea de sucesión temporal y atmosférica, que explora, además, en la progresión de uno u otro fenómeno por separado. Este aspecto pudo resultarle interesante a Bécquer como recurso plástico para dilatar el amanecer o el atardecer, según importase a los efectos ópticos y a la acción. Las estrofas I, II y XII, entre otras, reflejan esa idea de progresión en el amanecer:

El sol nace en Oriente; diríase al verlo que el genio de la luz, vencedor de las sombras, ebrio de orgullo y majestad, se lanza en triunfo sobre su carro de diamantes, dejando en pos de sí, como la estela de un buque, el polvo de oro que levantan sus corceles en el pavimento de los cielos. Las aguas, los bosques, las aves, el espacio, los mundos, tienen una sola voz, y esta voz entona el himno del día. (I-XII 110)

Aquí Bécquer expresa en términos líricos un sentimiento panteísta, que se nutre del opus loreniano, pero aun así, se manifiesta libre y exuberante como la naturaleza barroca, que, en ese sentido, tiene puntos en común con la romántica. Además, nos muestra un mundo perfecto de índole racional ${ }^{12}$, en equilibrio con la mente, que Bécquer, como Claude Lorrain, crea con su luz. Sigue, sin duda, el antiguo ideal horaciano de ut pictura poesis, pues el paisaje, la naturaleza en definitiva, traduce un sentido poético de la existencia y una visión armónica del universo. Por otra parte, cuando Bécquer destaca la luz y el color sobre la descripción material de los elementos, antecede de forma sorprendente a las investigaciones lumínicas y coloristas del impresionismo. Cabe señalar, abundando en este aspecto, que en "El caudillo" aparecen un sinnúmero de efectos óptico-lumínicos de amaneceres, 
atardeceres y algunas escenas del mediodía, que parecen estar determinados por la decisiva influencia de algunos de los pintores admirados por Bécquer, dentro del ideal del paisaje, que es la gran creación artística del siglo XIX. Sin embargo, no podemos obviar el afán de integración con la naturaleza del arte indio --fundamental en estas leyendas-- y el carácter divino del sol y la luna, fuentes de luz, entre otros elementos naturales, que constituyen en el texto de "El caudillo" elementos importantes de la composición paisajística. Así, aunque las escenas representadas son en gran medida invenciones, la plasmación de sus condiciones lumínicas, derivadas del estudio del paisaje, resulta convincente.

Otro elemento plástico en su obra, al igual que en los paisajes de Lorrain, es la presencia del sol o la luna, y los efectos refractarios de su luz en las nubes, en la calidad de la atmósfera y en los objetos que baña, a veces, mediante lo que ya hemos llamado construcción ecfrástica multisensorial:

La aurora rasga el velo de la noche; de sus trenzas de oro se desprende el rocío en una lluvia de perlas sobre las colinas y las llanuras, los horizontes del mar se encienden, y las crestas de sus olas brillan como las escamas de la armadura de un guerrero en un día de combate; de las flores, húmedas aún con las lágrimas del crepúsculo, se eleva al cielo una columna de aromas en emanaciones, perfumadas emanaciones que los genios, cruzando sobre las nubes celestes y amarinas, recogen con las matinales plegarias. (138)

Aquí concurren percepciones visuales, auditivas, olfativas y visionarias que conforman un cuadro de singular belleza sensorial, donde la luz del crepúsculo es el 
elemento principal de la composición. Tal parece que hemos presenciado la escena a través del "cristal de Claude", como se lo conoce en la historia del arte. Se trata de una lente de color, de diferentes formas, que permite no sólo seleccionar un encuadre del paisaje, sino traducirlo a la luminosidad dorada de Lorrain. El "cristal de Claude" transmite una experiencia visual de las luces del amanecer o del crepúsculo --como la descrita aquí por Bécquer-- así como del espacio natural, que se convierte por ese medio en una experiencia visual única desde el punto de vista icónico. No podemos afirmar, aunque tampoco negar, que Bécquer utilizara "el cristal" en algún momento de su trayectoria artística, puesto que no hemos encontrado ninguna mención de ello, aunque cabe suponer su uso en los talleres de pintura a los que asistió. De no haber sido así, debió conocer, al menos teóricamente, los efectos del "cristal", toda vez que el estudio de la luz era una parte importante de los estudios de pintura; y Bécquer, no lo olvidemos, fue alumno de dos destacados pintores sevillanos, coloristas por más señas: Antonio Cabral Bejarano y Joaquín Domínguez Bécquer, llamado por muchos "el pintor de los cielos" (Reina Gómez 150), por ser el artista que más importancia concedió al cielo (celaje en términos artísticos), y el que de una manera más elaborada lo trasladó al lienzo, dentro de ciertas reglas de sintaxis plástica propias del romanticismo andaluz.

Bécquer "nos dice", pero lo hace "mostrándonos" --como corresponde a su estilo-- algunas imágenes relativas a los cambios atmosféricos, y lo materializa, partiendo del principio de que la imagen no puede decir sin mostrar. De acuerdo con Diego Lizarazo, "la denotación icónica es, digamos, intrínsecamente estética o sensual; no habla para expresar un concepto, sino, principalmente, para producir 
una experiencia sensorial" (9-10), que es, precisamente, a lo que aspira Bécquer con sus construcciones ecfrásticas multisensoriales. Para la elaboración de éstas, Bécquer se servirá de toda una gama de recursos articulados en torno a la experiencia visual: el juego con la focalización, el empleo de sonoridades y olores, un uso detallado de la descripción y, fundamentalmente, una concepción artística de la escritura, dotada de una gran fuerza evocadora. Analicemos, en este sentido, su descripción de una tormenta:

La noche es oscura. El viento muge y silba, sacudiendo las gigantes ramas del boabad [sic] de las selvas. Los genios blanden sus cárdenas espadas de fuego sobre las nubes, en que se les ve pasar cabalgando. El trueno retumba, dilatándose de eco en eco en los abismos de las cordilleras. La lluvia azota el penacho de las palmas, y confundiéndose con los sordos mugidos de la tormenta, el prolongado lamento del vendaval y el temeroso murmullo de las hojas del bosque, se escucha por intérvalos [sic] un rugido lejano, ronco y estridente, que parece formarse en la cavidad de un pecho de bronce. (I-VIII 130)

Nos encontramos ante "un cuadro sonoro" de clara influencia romántica por el tema seleccionado: una tormenta. Una rápida enumeración de los términos que Bécquer utiliza lo prueba así. No faltan, desde luego, algunas percepciones visuales importantes: "cárdenas", "fuego", "oscura", así como la sobreentendida luz --no descrita-- de los relámpagos, que resultan en efectos lumínicos que logran un fuerte y deseado contraste con la oscuridad de la noche, mucho más acrecentada por la tormenta. Esta influencia romántica se percibe claramente, incluso en el "formato" 
de grandiosidad del cuadro, en el que la tormenta y el paisaje descritos pasan a ser el único motivo que inspira la descripción ecfrástica. Debemos destacar que dentro de los grandes descubrimientos del Romanticismo pictórico está la naturaleza y el cultivo del género del paisaje, que será exhaustivo, con especial énfasis en la valoración de los estados atmosféricos.

En este contexto, Bécquer construye aquí una composición dinámica, como corresponde al tema, que está marcada, además, por enunciados dramáticos donde predominan los tonos oscuros. Por otro lado, la descripción de la tormenta constituye un "canto" por sí misma; es decir, abre y cierra uno de los cantos o estrofas de la leyenda, lo que hace que la descripción ecfrástica --la narración, en definitiva-- represente una pintura hablante, en el sentido que le otorgó Simónides de Ceos.

A la luz de las relaciones analógicas, que es vital en nuestro análisis, no escapan ciertas conexiones con la obra del pintor inglés Joseph M. W. Turner, el llamado "pintor de la luz". Obras como $\underline{\text { Snow storm (1842) o Rain, Steam and Speed }}$ (1844), pudieron haber sido conocidas por Bécquer, a través de ilustraciones o reproducciones mecánicas, pues Turner era, para entonces, un pintor bastante conocido en los medios artísticos europeos por su forma personal de interpretar los efectos atmosféricos y por el papel de la luz en éstos, que son los rasgos más característicos de su peculiar estilo. Estos aspectos interesaban grandemente a Bécquer, ya que para él, los elementos compositivos del cuadro eran parte de su visión de la naturaleza, que se conformaba a partir de su contemplación y/e (re)interpretación del paisaje, y por su voluntad de "describir" y "representar" sus 
impresiones del mismo, lo cual debe ser visto como un todo, dentro del acto de (re)creación que realiza.

Aparecen en "El caudillo" otras manifestaciones de los efectos atmosféricos, que he creído conveniente agrupar, atendiendo al momento en que se producen. Con relación al amanecer, además de las ya mencionadas, tenemos las siguientes:

"Ya la estrella del alba anuncia el día; la luna se desvanece como una ilusión que se disipa, y los sueños, hijos de la oscuridad, huyen con ella en grupos fantásticos" (I-IX 109).

“La luna se desvanece ante los rayos del astro del día” (II-XVII 118).

"El sol se va levantando pausadamente del seno del mar y remontándose por la cumbre del firmamento" (V-IV 139).

"El día comienza a despuntar; la luna se desvanece y el mar se colora con las primeras luces del alba" (VII-XV 154).

Concurren en estas descripciones algunos elementos que definen una parte importante del discurso pictórico de Bécquer, ordenados de acuerdo con la presencia de un foco lejano de luz en el "cuadro", que se acusa en la plenitud de su origen solar, al que Bécquer llama, indistintamente, "estrella del alba", "astro del día" o "sol", entre otros nombres. Esta luz de amanecer se derrama sobre las cosas y, según la materia que la recibe, da lugar a parpadeos, transparencias, reflejos sobre el agua (como ocurre en el mar descrito), coloraciones o superficies evanescentes. Asimismo, el desvanecimiento o esfumado --el llamado sfumato-- de la luna, como técnica pictórica, a la que hemos aludido antes, contribuye a desdibujar su presencia en el cuadro; elemento que es desplazado por la intensa luz solar, verdadero 
protagonista de la composición, dentro de un canon esencialmente loreniano. En muchos casos, el horizonte, con la intensa luz del amanecer, desaparece en medio del resplandor que se proyecta hasta los primeros planos, creando una sensación de profundidad que conduce a la vista hacia los planos lejanos del cuadro pictóricodescriptivo.

Como contrapunto de las auroras, y tan importantes como éstas en la obra de Claude Lorrain, Bécquer nos pinta una serie de crepúsculos de decidida impronta romántica, que son, de acuerdo con la crítica, de las mejores descripciones ecfrásticas que hallamos en las Leyendas. Analicemos otros ejemplos, además de los ya expuestos:

"La noche vence, el cielo se corona de estrellas, y las torres de Kattak, para rivalizar con él, se ciñen una diadema de antorchas. ¿Quién es ese caudillo que aparece al pie de sus muros, al mismo tiempo que la luna se levanta entre ligeras nubes más allá de los montes en cuyos pies corre el Ganges como una inmensa serpiente azul con escamas de plata?" (I-IV 107).

"Los árboles recobran su lozanía, la liana su verdura, los pájaros su voz, y a la indecisa y cárdena luz del cielo sucede el tranquilo y suave esplendor de una noche estrellada y llena de armonías, perfumes, suspiros y cantares" (IV-XXII 136).

"La noche borra del cielo los colores, y las nubes, las estrellas, mudos testigos de los pesares y la felicidad de los amantes, aparecen una tras otra rodeadas de un ligero censal de bruma" (IV-XXV 137). 
En las tres citas anteriores, Bécquer se vale de un fuerte contraste entre las sombras de la noche y la luz de las estrellas o de las antorchas que iluminan a Kattak. Este contraste exagera las distancias y otorga un cierto relieve a los objetos en la lejanía. Las pinceladas de color se limitan al color verde de las lianas, al azul y al tono plateado del Ganges, pero son sólo eso, pinceladas aisladas, aunque destacan en el oscuro paisaje. El uso de "colores", pero sin detallar cuáles, parece hablarnos desde una pluralidad calculada. Lo más significativo, sin embargo, no es tanto la pintura del paisaje nocturno, muy dentro de las normas lorenianas, como el hecho de que las reglas habituales de la percepción se ven alteradas por la atmósfera de quietud que emana de las descripciones auditivas y olfativas por sobre las pictóricas, a la que parecen contribuir, muy acertadamente, expresiones como la "lozanía" de los árboles, el "tranquilo y suave esplendor", los "mudos testigos", las "armonías", así como los "perfumes", "suspiros" y "cantares". Así, Bécquer nos permite contemplar una suerte de locus amoenus que, por presentar unas coordenadas distintas a las de la realidad habitual, tiene mucho de "fantástico" y de "maravilloso", lo cual imprime el tono deseable a los relatos legendarios becquerianos; tono muy vinculado, por otra parte, con la tradición oriental en general, tanto árabe como india.

Muy distinto a estos atardeceres, en su tono, ambiente y poco colorido, es el siguiente crepúsculo:

Las nubes, amontonándose en el Occidente, envuelven el cadáver del sol en un sudario de brumas antes que descienda a su sepulcro. La noche se adelanta; una noche sin astros y sin transparencia; la brisa 
murmura la oración de los muertos, sollozando melancólica entre los espesos juncos; el perfume de las flores que se abren en la sombra vaga del espacio; el grito del chakal [sic] y el silbo de las aves nocturnas resuenan confundiéndose con esos rumores siniestros y misteriosos que nacen, tiemblan y se dilatan en el seno de la oscuridad. (V-IX 140-1)

La atmósfera que nos describe Bécquer es oscura y tenebrosa. La gradación sombría del lugar se acrecienta según avanzamos en la descripción ecfrástica, que apela, sobre todo, a percepciones auditivas, olfativas e imaginativas, como complementos sustanciales de las pictóricas. Escuchamos el grito del chacal y de las aves nocturnas, confundidos con los ruidos siniestros y misteriosos de la noche; sentimos, también, el perfume de las flores, pero no vemos a ninguno de ellos. Nuestra mirada tiene que ir adivinando sus formas, si acaso, en la profunda y tenebrosa oscuridad del cuadro. La lúgubre escena transmite un sentimiento de honda tristeza y desolación de muerte, que contribuye a acentuar, todavía más, un espectro cromático limitado únicamente a tonos umbrosos. De acuerdo con Begoña González, “[1]a escenografía nocturna [y] funeraria es quizás uno de los puntos más tópicos del mundo del romanticismo, enlazando con una de las tendencias más distintivas en lo espiritual: subjetivismo, pesimismo, duda, rebelión del individuo; supremacía de la pasión, la fantasía y el sentimiento sobre la razón" (17). Pero este ambiente de muerte, tras la tormenta, es también un espectáculo hermoso para la pintura y, como tal, digno de ser "representado". El paisaje oscuro es también consustancial al alma romántica y al pensamiento de la muerte: "[La] afición a los 
claroscuros y a los cementerios, a los elementos naturales desatados para ambientar las agonías, los crímenes, las apariciones, tiene en ocasiones un acento teatral" (Begoña González 62). También acusan de esta visión teatral, o también, "visión escenográfica", algunos de los crepúsculos becquerianos, descritos, eso sí, con tintas más coloristas y lumínicas:

El sol, recostado en un lecho de púrpura y oro, como un rajá en su alfombra de colores, lanza a la tierra el último rayo de sus entreabiertos ojos... Las brisas de la tarde, impregnadas de murmullos y perfumes, juguetean con el cáliz de las flores que se abren a sus besos. Las aguas del Ganges, copiando en sus linfas transparentes la vigorosa vegetación de sus riberas, alzan un himno melancólico al que se unen las aladas y suaves notas de los pájaros, que despiden al día con un dulcísimo y triste adiós. (IV-XXIII 136)

De nuevo aquí concurren percepciones auditivas y olfativas, pero como complemento de las pictóricas, que son, a no dudarlo, las verdaderas protagonistas de esta écfrasis multisensorial. La personificación del sol, como fuente de luz, contribuye al símil con el rajá. La abierta descripción de la alfombra, que Bécquer califica como "de colores", nos hace visualizar una rica paleta de pigmentos y tonos, muy posiblemente dentro del colorido de los crepúsculos de Turner, e incluso de Lorrain, para quien los tonos de rosa (o rosicler) y del naranja eran el componente obligado de sus atardeceres. De nuevo aparece aquí el agua como materia refractaria del color de las riberas --que visualizamos, por el uso del adjetivo "vigorosa"--, de una rica gama de verdes. La idílica visión del cuadro se 
complementa con una reposada composición musical-olfativa, creada a partir de la suavidad de la brisa perfumada y del canto y vuelo de los pájaros; nada más cercano a las estudiadas y equilibradas composiciones de Lorrain.

Por otra parte, conviene destacar en "El caudillo" otras descripciones iconotextuales de singular valor plástico, además de las relativas a los fenómenos atmosféricos, pero con características muy especiales, pues a veces, Bécquer sólo nos presenta el "cuadro" para que completemos el texto narrado; es decir, la imagen --o icono visual-- sirve como complemento enriquecedor del icono textual. En otros casos, apela al recurso de introducir un personaje-observador interpuesto entre éste y lo narrado, para así subrayar el papel de espectador del cuadro "descrito", que se espera del lector de las Leyendas. Sin embargo, a pesar de lo que podamos inferir de este recurso, el observador interpuesto no aparece únicamente para darle visos de realidad --a manera de justificación, si se quiere-- a lo que dice y ve el personaje, como parte del relato, sino, además, para destacar también en éste su papel como parte del "público-espectador" de la écfrasis construida. Es esto lo que ocurre en el siguiente ejemplo:

El cuervo prosigue así:

--¿Ves allá, entre los espesos cañaverales, encenderse una llama ligera y cárdena, que vacila y corre sobre el haz de las fétidas aguas del pantano? Más lejos, al pie de la colina, donde a la sombra de un bosque sombrío se levanta un grosero sepulcro, formado de piedras toscas e irregulares, ¿ves cómo se desarrolla el brillante fluido, y vuela sobre la tumba, y se detiene junto a los troncos de los árboles, y se 
multiplican, subdividiéndose en mil, otras llamas fantásticas, ligeras y de un azulado resplandor? (V-XXI 144-5)

Aquí, Bécquer se vale de un personaje del relato, el cuervo, que se ha colocado entre el lector-espectador y lo narrado, como observador privilegiado. De hecho, al mostrarle el "cuadro" a Pulo, desde la ficción del relato, lo muestra y lo hace "ver" a los lectores-espectadores en todos sus detalles. Pero, además, el cuervo es también parte de ese necesario público-espectador del "cuadro", y lo hace desde las reglas que las condiciones de la representación demandan del personaje.

Por otra parte, en "La Creación", Bécquer nos presenta escenarios muy similares a "El caudillo", como cabe esperar de ambientes comunes --y momentos de ejecución cercanos-- en cuanto al paisaje, aunque el tono humorístico que le otorga la presencia de niños en un laboratorio --que más parece el taller de un pintor-donde llevan a cabo la creación del mundo, nos remite a las escenas de niños en las obras de Murillo, cuyo estilo y temática fueron estudiados al detalle por los Domínguez-Bécquer y por el círculo de pintores sevillanos frecuentado por Bécquer. El cuadro de este laboratorio, pintado por Bécquer, es quizás una de las mejores descripciones ecfrásticas de esta leyenda:

Pintar la escena que entonces se verificó en aquel recinto sería imposible.

Primeramente examinaron todos los objetos con el mayor asombro; luego se atrevieron a tocarlos, y al fin terminaron por no dejar títere con cabeza. Echaron pergaminos a la lumbre para que sirviera de pasto a las llamas; destaparon las redomas, no sin quebrar algunas; 
removieron las vasijas, derramando su contenido, y después de oler, probar y revolverlo todo, los unos se colgaron de los soles y estrellas aún no concluidos y pendientes de la bóveda para secarse; los otros se subían por las osamentas de los gigantescos animales cuyas formas no habían agradado al señor. Y arrancaron las hojas de los libros para hacer mitras de papel, y se colocaron los compases entre las piernas, a guisa de caballo... Por último, cansados de enredar, decidieron hacer un mundo, tal y como lo habían visto hacer. (XIV 183)

En su ya peculiar estilo, Bécquer comienza la descripción pictórica, asegurando la imposibilidad de "pintar" la escena, por demás, de un gran movimiento --casi nos atreveríamos a decir "cinematográfico"--, con lo cual corrobora, por un lado, la imposibilidad de describir con palabras un lugar así, pero, por otro, intenta "pintarla" --precisamente, a través de las palabras-- de la mejor forma posible, para que así tengamos una idea de ella. Debo insistir, otra vez, en la enorme capacidad que otorga Bécquer a las imágenes, esto es, al objeto visual, para completar el cuadro descriptivo narrado. Y lo hace llevándonos detenidamente por el recorrido que hacen los traviesos y personajes --verdaderos émulos de los pilluelos de Murillo--, como lo haría la lente de una cámara, enfocando esta y otra escena, a fin de aumentar la capacidad plástica de la descripción. No hay duda de que Bécquer nos hace "ver" el laboratorio de Brahma en todos sus detalles pictóricos, pero lo hace con los ojos de un artista.

Si la écfrasis se define desde antiguo --y lo sintetizamos con la definición ya mencionada en este trabajo de Claus Cluver-- como "la representación verbal de un 
texto real o ficticio compuesto por un sistema sígnico no verbal" (26), entonces el movimiento que caracteriza a la escena --aunque lo reconozcamos como precursor del cinematógrafo-- no deja de ser una descripción ecfrástica, distinta, eso sí, y mucho menos restrictiva que la definición que la circunscribe únicamente a la descripción de un cuadro; definición mucho más reciente, como ya hemos señalado en el capítulo I. En ese sentido, podríamos utilizar la definición de "écfrasis dramática" de Frederick A. de Armas, "donde se activa una escena estática dentro de un texto, proveyéndola de movimiento y acción" (61).

No hay en las diecinueve estrofas de "La Creación" --una leyenda no muy extensa-- ninguna escena del amanecer o del crepúsculo, como abundan en "El caudillo", pero encontramos otros elementos cromáticos que producen un efecto de gran plasticidad. Para ello, Bécquer se sirve de símiles y expresiones de intenso colorido o cargados de luz: "el cocodrilo, verde como las hojas de las plantas" (I 177); rayos de sol como "polvo de oro" (IV 179); astros semejantes a los soles, "girando sobre sus ejes de diamante y oro" (XII 182); "nubes de ópalo... que derraman un rocío de perlas" (I 177); "larga cadena con eslabones de oro" (I 177); "llamaradas azules y rojas que saludaba la alegre muchedumbre" (XV 184); entre otras analogías llenas de color y de luz, que subrayan el carácter pictórico de esta leyenda india. Los juegos alquímicos, por otra parte, se asocian a las culturas orientales. Regueiro Salgado alude a un artículo de Leslie Deutsch-Johnson, en el que analiza el papel de la magia y la alquimia en los relatos becquerianos. A este respecto, nos dice: "Y esto mismo [alude a la alquimia], asociado de nuevo a la cultura oriental, en este caso, la hindú, aparece en 'La creación', donde se dice de 
Brahma que, 'buscando una distracción con que matar su eterno fastidio, después de cerrar la puerta con dos vueltas de llave, entregóse a la alquimia" (191). La mención de Bécquer a "figuras geométricas, signos cabalísticos y fórmulas mágicas" (Leyendas 182) en esta leyenda, vienen a corroborar lo expuesto por DeutschJohnson en su artículo.

He venido analizando hasta ahora la capacidad expresiva de la pintura como un sistema de signos icónicos integrado en las Leyendas, a manera de descripciones ecfrásticas, pero conviene señalar algunos aspectos importantes desde el punto de vista crítico. Primeramente, Maurice Beuchot afirma que el “icono no es únicamente visual, también es verbal" (20). Por lo tanto, concluye que "el icono visual contamina las palabras que se usan para describirlo y el icono verbal contamina las imágenes con las que se lo trata de representar" (20). La iconocidad, agrega, "se ha aplicado a varias ramas (música, literatura, etc.), pero, sobre todo... a las artes visuales" (20).

De lo anterior se desprende que el icono tiene su base, digamos, en los mensajes visuales, pero también se da en mensajes auditivos y, desde luego, en otros tipos de mensajes sensoriales. Beuchot concluye que "el buen narrador, el buen poeta, logra producir en nosotros el icono que desean transmitir. Llenan de imágenes nuestra mente, y lo hacen a través de la palabra. Un buen pintor produce en nosotros los iconos de los sentimientos que desea expresar. 'Parece que habla', al igual que decimos de un buen escritor, cuando nos relata algo, que 'parece que pinta"' (25). Además, nos dice, "el signo icónico es el que más necesita de la interpretación, para 'hacerlo hablar'. Es algo que no habla por sí mismo, intermedio, como está, entre el índice, que es signo natural, y el símbolo que es signo artificial o 
convencional" (25). Cabe suponer, a la luz de la visión de Beuchot, que el icono necesita de una hermenéutica apropiada. En tal sentido, especifica que "[h]a de ser una hermenéutica analógica, o icónica, o analógico-icónica, es decir que se base en los mismos caracteres del signo icónico para interpretarlo, para respetar su riqueza, para resguardar su complejidad" (25).

El análisis de Beuchot favorece mi abordaje desde las artes visuales, desde la pintura, fundamentalmente, pues en estas artes predomina el aspecto icónico, y se produce, además, la analogía, la semejanza, por lo que se demanda de ellas una hermenéutica analógico-icónica, como la enunciada por Beuchot. Además, la pintura es, posiblemente, la analogía más efectiva, habida cuenta del carácter escenográfico de esta India europea "pintada" por Bécquer, mucho más próxima a una reproducción impresa o a una representación pictórica, que a una realidad geográfico-cultural. En definitiva, la India de Bécquer es, sobre todo, el reflejo de un discurso de creación europea, integrado por representaciones, "no retratos 'naturales' de Oriente" (Said 40). Las fuentes escritas de que se vale Bécquer para (re)crear esa India --las que hemos mencionado-- estaban ya marcadas por las influencias ideológicas del momento en que se originaron, e incluso en que fueron traducidas, puesto que no fueron creadas en un espacio vacío. Bécquer acepta esa visión eurocéntrica que le llega, digamos, de forma indirecta --con todas las limitaciones que esto suponía-- para enfrentar una realidad que ya estaba definida de antemano, al menos en los componentes ideológicos a que nos hemos referido. 


\section{NOTAS AL CAPÍTULO III}

1 "El caudillo de las manos rojas, tradición india” fue publicada en La Crónica, entre el 29 de mayo y el 12 de junio de 1858; “La Creación, poema indio"se publicó en El Contemporáneo, el 6 de junio de 1861; y "Apólogo", por último, apareció en las páginas de La gaceta Literaria, el 28 de febrero de 1863.

${ }^{2}$ Las mil y una noches de Antoine Galland (París, 1838); las Cartas persas de Montesquieu, por Machena (Nimes, 1818); Gonzalo de Córdoba o la conquista de Granada de Florian, por Juan López de Peñalver (Madrid, 1794); Viajes de Antenor por Grecia y Asia de Lantier (Madrid, 1802); Pablo y Virginia de Bernardin de SaintPierre, por José Miguel de Alea (Madrid, 1798); y El inglés en la India o La cabaña indiana del mismo autor (Salamanca, 1803), entre otras.

${ }^{3}$ Manuela Monnehay Moreno era hija de un comerciante francés de perfumes, cuya tienda y vivienda se encontraban en la Plaza del Duque de Sevilla. Fue alumna de los cursos de pintura del padre de Bécquer, José Domínguez Bécquer. Parece ser que se estableció cierta relación de amistad entre ambas familias, hecho que motivó que el padre de Bécquer le permitiera amadrinar a su hijo Gustavo Adolfo. Es muy probable que Bécquer haya iniciado los estudios de francés con ella.

${ }_{4}$ Se refiere a George Sand (1804-1876), seudónimo de Amandine Aurore Lucile Dupin, baronesa Dudevant, escritora francesa.

${ }^{5}$ Supongo que se trata del escritor romántico francés Alfred Louis Charles de Musset (1810-1857), quien entre 1833 y 1835 mantuvo un apasionado romance con la novelista George Sand. Por lo tanto, sería A. de Musset.

${ }^{6}$ Cristóbal de Castro opina que "El caudillo" fue escrito después "de una asombrada y rápida lectura del Ramayana" (Cit. por Berenguer Carisomo 43). Más aún, apunta Carisomo, esta tradición india "tiene algunos fugaces puntos de contacto con la historia marital de Nal y Damayanti en el Mahabharata" (43), obra que ya había sido traducida al francés en 1857. No debemos olvidar que las traducciones al francés de estas dos obras capitales, bien en sus formas completas o en traducciones fragmentarias y en resúmenes, fueron bastante populares en la primera mitad del siglo XIX. Según señala Díaz Plaja en su Introducción al estudio del romanticismo español, "se trata todavía de vergonzantes traducciones o imitaciones de breve medida, pero que acusan un notable interés por este tipo de literatura" (131).

7 Rica Brown la sitúa "sin vacilar en el año 1857" (93), Gamallo Fierros señala "el año 1858" (109). Rodríguez Correa recuerda esa circunstancia en el prólogo, citado por Rubén Benítez:

El año [18]57, Bécquer se vio acometido de una horrible enfermedad, y para atender a ella y rebuscando entre sus papeles, hallé "El caudillo de las manos rojas, tradición india", que se publicó en La Crónica, siendo reproducida con la singularidad de 
creerse que el título de tradición era una errata de imprenta; pues todos los que la insertaron en España o copiaron del extranjero la bautizaron con el nombre de 'traducción india'... Tan concienzudamente había sido hecho el trabajo. (110)

${ }^{8}$ En 1857, además, ocurre la rebelión de los cipayos contra los ingleses, un hecho que alcanzó una gran repercusión mediática en Europa. El periodismo francés, en su tradicional animosidad contra los ingleses, publica las noticias sobre estos hechos, ambientándolos, según consta, en escenarios de un marcado acento pintoresco e ilustrándolos con grabados que se inscriben en lo costumbrista. Cabe deducir, por otra parte, a pesar de la poca resonancia que tienen estos hechos en España, que Bécquer, en su calidad de periodista, haya podido acceder a estas noticias, publicadas en una lengua que conocía muy bien. En cualquier caso, hay ciertos detalles, escenas y personajes que nos remiten a obras publicadas con anterioridad.

${ }^{9}$ Los "tableautins" se destinaban, sobre todo, al turismo. Era una forma de trabajar que Bécquer conocía por su padre, José Domínguez Bécquer.

${ }^{10}$ Para Robert Pageard --y coincidimos en ello-- esta es, posiblemente, "una de las más finas evocaciones del crepúsculo entre todas las que se hallan en los escritos de Gustavo Adolfo" (227).

${ }^{11}$ Los biógrafos de Bécquer destacan un don particular para la interpretación musical. Según los recuerdos de Nombela, durante sus dilatados periodos de reposo, "[e]l amor a la música, particularmente a las óperas de Bellini, contribuyó a mantener el equilibrio de Gustavo Adolfo" (Pageard 124-5). Parece ser, por otra parte, que Bécquer tocaba el piano con relativo acierto, aunque no recibió una preparación formal para ello, pero poseía, según algunos de sus contemporáneos, aquello que se ha dado en llamar "oído" para la música, y esta cualidad se pone de manifiesto en la prosa musical de las leyendas.

${ }^{12} \mathrm{El}$ arte barroco pretendía evocar la emoción y la pasión en lugar de la tranquila racionalidad que había sido apreciada durante el Renacimiento, y que se observa aquí. 


\section{CAPÍTULO IV}

\section{LA EDAD MEDIA EN LA COMPOSICIÓN ESCENOGRÁFICA Y EL PAISAJE DE LAS}

\section{“LEYENDAS”}

Yo creo que he visto unos ojos como los que he pintado en esta leyenda. No sé si en sueños, pero yo los he visto. De seguro no los podré describir tal cual ellos eran: luminosos, transparentes como las gotas de la lluvia que se resbalan sobre las hojas de los árboles después de una tempestad de verano. De todos modos, cuento con la imaginación de mis lectores para hacerme comprender con éste que pudiéramos llamar boceto de un cuadro que pintaré algún día

Gustavo Adolfo Bécquer

"Los ojos verdes"

En el siglo XIX se produjo un interés por las manifestaciones artísticas del pasado, una actitud que se inició con los ilustrados a mediados del siglo anterior. Escritores y artistas buscaron en el pasado lejano --sobre todo en la Edad Media-las raíces necesarias para poder expresarse de acuerdo con la nueva estética. Los motivos que despertaron esa búsqueda partieron de variadas fuentes: del interés arqueológico o etnológico por el pasado, mitificadas por sentimientos románticos; de la sustitución de una sicología de las facultades del alma por una sicología de los individuos, un rasgo decididamente romántico; de los inicios de la Revolución Industrial, lo que conllevaba el final de las estructuras productivas imperantes hasta ese momento; así como del creciente interés por las producciones autóctonas y exóticas, consecuencia del avance colonizador a regiones antes casi desconocidas para los europeos, entre otros motivos. A partir de estos cambios de la sociedad 
europea se hilvanó una nueva trama de estilos de carácter sincrético y ecléctico que buscaba un nuevo camino ante el abandono de los modelos clásicos, pero que, paradójicamente, se convertiría en una reinterpretación de viejos modelos estéticos. Este nuevo estilo, que designa un interés histórico por las manifestaciones del pasado, responde al término algo vago de "Historicismo", del que se derivaron otros nombres, dependiendo de circunstancias muy particulares. Existen dos acepciones para el término del historicismo, una de ellas, correspondiente a las ciencias sociales, establece que el conocimiento humano es el resultado de los acontecimientos históricos y que no es posible que uno se dé sin la presencia el otro. El historicismo postula la teoría de que la realidad humana, tal y como la conocemos hoy en día, es la suma de todos los acontecimientos históricos; por ende la realidad es el producto de la historia. La otra acepción que tiene el término historicismo, la que nos interesa en este análisis, tiene que ver con la evocación del pasado artístico. Nos centraremos en esta vertiente, fundamentalmente.

A ese aludido interés de los románticos por la Edad Media, como expresión de su "huida" en el tiempo (El Romanticismo es una huida a lo que existe previamente, marcada por el deseo de presentarla de otra manera), se acompaña una revisión de las tradiciones nacionales, a la luz del argumento que propugnaba que las obras debían acompañar valores étnicos a su propia expresividad; de esta manera se unía lo medieval a lo folclórico en una nueva simbiosis histórico-cultural. Así, en este marco de confluencias, se producen algunas evocaciones del pasado en el campo de las artes, las comúnmente llamadas revivals, motivadas, precisamente, por esa búsqueda en el pasado de elementos que conformasen una nueva visión o 
manera de "ver", de acuerdo con los ineludibles cambios que tenían lugar en el horizonte artístico europeo. Es decir, se buscaba una nueva estética, y para ello se partía del presupuesto de que el pasado artístico podía proporcionar --como lo hizo de forma más o menos anacrónica o de fidelidad a la época-- aquellos elementos necesarios que fueran capaces de interpretar la nueva corriente artística. El primer estilo que apareció, ya dentro del Romanticismo, es el gótico, que llamarían "neogótico", pero a medida que se avanzó en los estudios arqueológicos, surgieron el "neorrománico", el "neomudéjar", el "neobizantino", el "neogriego" y el "neoárabe”, entre otros, que aspiraban con el prefijo "neo" a crear nuevas variantes, pero siempre a partir de movimientos y estilos ya consagrados por la historia del arte.

En este contexto, debemos entender que el Romanticismo y el Nacionalismo del siglo XIX revalorizaron la Edad Media como reacción antiacadémica, y porque constituía una parte importante de su programa estético. Además, porque era visto como el único recurso para encontrar en ese período de la historia las raíces con que dotar al emergente nacionalismo europeo--y español en nuestro caso-- de una necesaria base histórica. Así, una serie de instituciones académicas, tanto de carácter nacional como regional --entre las que destacan las alemanas, las inglesas y las francesas, pero que no excluyen otras, como las españolas y las belgas-- se centran en los estudios medievalistas, editando un sinnúmero de obras que fueron el fruto de las investigaciones de sus respectivos pasados medievales.

En España, el desarrollo del "Historicismo" jugó, además, un importante papel por las difíciles circunstancias históricas que habían provocado una profunda crisis de su identidad nacional. El pasado histórico-medieval español venía, 
entonces, a fungir--por tratarse de una etapa particularmente grandiosa para el país-- como elemento aglutinante y regenerador de su presente, con el claro propósito de sacar al país de esa crisis identitaria en la que se hallaba inmerso. Por otra parte, en el caso de Bécquer, su particular visión en el análisis y/e (re)interpretación de ese pasado dieron por resultado dos vertientes del "Historicismo artístico", que llamaré, por un lado, "recreación arqueológica pura", con fórmulas más o menos "fidedignas" --hasta donde podemos aceptar lo que es "fidedigno"-- a tenor del conocimiento que poseía Bécquer en su papel de "intérprete". A la segunda vertiente, la llamaré"(re)interpretación arqueológica", en la que concurre una mayor libertad en la "(re)lectura" de las fuentes originales, que obedece, sobre todo, a que Bécquer no respeta con toda intención el modelo original por imperativos de la "(re)creación artística", a la que se subordina en detrimento de la narración y de los elementos artísticos ambientales que refleja. Así tenemos que Bécquer, por requerimientos de la composición artística y por el propósito del "cuadro" que construye, se ve forzado a (re)interpretar la historia y los monumentos, o parte de ellos, de una forma más libre, menos sujeta a los hechos. Esta recreación arqueológica genera resultados sorprendentes en más de un sentido. En algunos casos, Bécquer apela a la inclusión de algunos elementos extemporáneos, dando lugar a una nueva variante, que constituye para muchos críticos una corriente con características muy particulares: el llamado "eclecticismo"1, que no debe verse, necesariamente, como una expresión artística negativa o desprovista de valores plásticos, aunque sí alejada, en muchos casos, de los modelos en los que pretendía inspirarse. En el caso de Bécquer, estos 
anacronismos se producen de forma aislada, casi siempre en elementos decorativos del ambiente o del vestuario, pero la ruptura de las reglas temporales se produce por un interés estético, no por desconocimiento de la historia ni de sus monumentos, lo que termina por colocarlos dentro del primer caso.

La crítica no ha considerado al "Historicismo" como un estilo artístico, en el más amplio sentido del término, aunque sí un movimiento de cierto peso. De hecho, se habla de un "Historicismo artístico". Hoy se interpreta como una corriente intelectual que abarca diferentes doctrinas y teorías del siglo XIX, cuyo factor común es una relación de afinidad programática con la historia. De forma general, como refiere Nieto Taberné, "el Historicismo es un modo de análisis y de reflexión sobre la realidad que caracteriza el pensamiento contemporáneo, es decir, el siglo XIX y el XX" (1). De acuerdo con este modo de análisis, cualquier acontecimiento debe ser examinado desde el lugar que ocupa, es decir, desde su posición en el espacio temporal. Para Nieto Taberné, además, "los acontecimientos del pasado están unidos y tienen relación unos con otros... Esta nueva idea determina que el romanticismo busque su eslabón histórico, que encontrará en la Edad Media, período recuperado por los románticos" (1).

Los primeros acercamientos a los estilos históricos, ya desde finales del siglo XVIII, se llevan a cabo en busca de un modelo alternativo, tal y como ya hemos abordado. Sin embargo, este primer Historicismo no se presenta tan cargado de ideología y nacionalismo, como se verá ya en pleno siglo XIX, con la recuperación y puesta en valor de viejos modelos nacionales. Además, paralelamente a esa búsqueda del "modelo", se había ido desarrollado una suerte de "arqueologismo"2, 
que será el instrumento esencial del que se vale Bécquer para la elaboración literaria --y pictórica-- de estas leyendas. El estudio y los apuntes gráfico-artísticos de la arquitectura religiosa del pasado --que constituyen el punto de partida de la Historia de los templos de España como ya ha quedado comprobado en este trabajo-- y su acercamiento romántico a las arquitecturas reproducidas o a las ruinas de éstas, desde una perspectiva histórico-artística, conforman esa necesaria base que Bécquer utiliza para la (re)creación del escenario medieval de estas leyendas. Por otra parte, debo subrayar, a tenor de la seriedad de su trabajo, que estos escenarios no son el resultado de una mera recuperación y reproducción superficial de viejos estilos, sino el resultado de un profundo análisis de estas arquitecturas nacionales, de sus elementos compositivos y colorido, así como de la ambientación exterior e interior de estas construcciones. No hay duda de que más de un pintor está presente en estos escenarios, pero el peso de Lorrain, Poussin, Murillo y Friedrich se hace evidente.

Entre 1860 y 1863, Bécquer publica la totalidad de sus leyendas de trasfondo medieval $^{3}$, además de una serie de trabajos clave de su producción literaria. La crítica coincide, por otra parte, en que se trata del periodo más fecundo del autor en cuanto al número, calidad literaria e importancia de las obras que produce. De la seriedad del abordaje de Bécquer al estudio de los edificios y monumentos, da fe Robert Pageard: [S]entía bien el encanto de la restitución del pasado así como el placer del contacto con el documento o el vestigio material antiguo" (203). Por su parte, Rubén Benítez ha destacado en su obra ya citada, Bécquer tradicionalista, que la "formación artística de Bécquer y su buen gusto le permitieron... un mayor goce 
en la directa descripción de los templos. Para ello, el poeta realizó... una investigación personal, viajando en diversas oportunidades..., tomando apuntes gráficos de los edificios, anotando sus primeras impresiones" (81-2), tal y como el mismo Bécquer avala en sus Cartas literarias a una mujer (IV). Esto es importante en más de un sentido, puesto que destaca el carácter "fidedigno", es decir, de "recreación arqueológica pura", o bien de “(re)interpretación arqueológica", cuando Bécquer se decanta --obligado por imperativos de la construcción ecfrástica-- por una representación parcial de las fuentes.

Rubén Benítez también señala que el "tradicionalismo artístico de Bécquer, como el de Chateaubriand, supone la aceptación de una especial idea sobre la historia" (50), en que los límites entre la literatura y la historia se tornan menos perceptibles. Además, cabe destacar que los historiadores que influyen en la obra de Bécquer, a través de Chateaubriand --Thierry, Michelet y Carlyle, entre otros-- se propusieron unir a la información "verídica" la reconstrucción artística del mundo espiritual del pasado.

No debe extrañar, entonces, que el nombre de Bécquer aparezca entre los "historiadores" y "arqueólogos" que redactarían la Historia de los templos de España. En este sentido, tampoco debe extrañar que la "pintura" de los ambientes de estas leyendas, entre los que destacan palacios, castillos, iglesias, ruinas, entre otros elementos compositivos del cuadro, sean abordados por Bécquer desde idénticos presupuestos, si ello contribuye a privilegiar la imagen plástica --es decir, el objeto visual-- haciendo que ésta constituya el complemento necesario al objeto textual o sustituya a éste, como parece ser en muchos casos. 
En cuanto a sus preferencias arquitectónicas y artísticas, en general, ya en “El Cristo de la Luz", encontramos rasgos evidentes de cierto rechazo a la arquitectura renacentista, a la que Bécquer llama "delirio de la representación clásica, que así en el terreno de las ideas como en el de las cosas trajo el Renacimiento" ( $\underline{\text { Obras }}$ completas 991). Para Bécquer, la Edad Media, sintetizada en la ojiva gótica, venía a representar el Cristianismo, de la misma forma que el arco de herradura --y el arte árabe en general--sintetizaba el Islamismo. Como afirma en "El pendón de guerra del gran cardenal Mendoza y la espada de Boabdil [sic]”, "El arte completa en ambos la idea histórica y hace más comprensible la muda lección que ofrecen" (ㅁbras completas 844). Este punto de vista de Bécquer, reafirma su idea de que la imagen -representada por el elemento arquitectónico de la "ojiva gótica"-- transmitía una idea de religiosidad cristiana al fundir el símbolo con el concepto, a manera de sobreimpresión, con la finalidad de potenciarlo aún más. De igual manera, el arco de herradura --otro elemento arquitectónico representativo del arte árabe-- se funde con la imagen del islamismo. A ello se refiere también en "El Cristo":

El estilo ojival, que cada día adelantaba más en la senda de la perfección, comenzó a oscurecer y a poner en olvido el arte arábigo, el cual no obstante prolongó su existencia, aunque trabajosamente, hasta mediados del siglo XVI, en que el Renacimiento destronó a un tiempo a los dos géneros, representantes el uno de la religión cristiana y el otro de la islamita [sic]. (Obras completas 997)

Este destronamiento al que alude Bécquer, sin embargo, no debe ser interpretado como un rechazo al arte árabe, pues él fue un profundo admirador del 
mismo, como es sabido. Lo que sí parece explicar --en términos artísticos-- es que, durante el Renacimiento, "la ojiva gótica", como símbolo indiscutible del cristianismo, comenzó a desplazar al "arte arábigo", símbolo artístico del Islam. En el contexto histórico de la Reconquista y las ulteriores medidas tomadas por la monarquía castellano-aragonesa, esto debe ser interpretado como un desplazamiento religioso de naturaleza histórica. Esta sutil comparación no deja de ser representativa de su práctica habitual de utilizar elementos artísticos; esto es, imágenes plásticas, para transmitirnos una idea, pero lo hace a través de símbolos artísticos. Por otra parte, Bécquer parece explicar, no sólo la raíz esencialmente cristiana de su visión artística, por demás identificada con la estética romántica, sino, además, su interés por los atmósferas medievales y exóticas; traduciendo estas últimas en la creación de ambientes árabes e indios, más o menos fidedignos, pero siempre artísticos, tal y como refleja su obra narrativa.

De los elementos que la pintura de Bécquer integrará en las Leyendas, la naturaleza y las construcciones arquitectónicas, ya fuesen castillos, abadías, monasterios o templos religiosos, serán los principales escenarios en que se enmarcarán las acciones. En cuanto a los entornos naturales, es posible distinguir dos escenarios recurrentes: las pequeñas aldeas o poblaciones, o ciudades como Toledo, con un ingrediente histórico-artístico destacado, por un lado, y el paisaje agreste y solitario, por otro, sobre todo el relacionado con el Moncayo y sus alrededores.

La presencia de las ruinas, por otra parte, constituye un elemento artístico insoslayable en el cuadro recreado por Bécquer, por su valor referencial con el 
pasado, y por su interés, ya explicado, en los vestigios históricos. Su mirada al pasado no es un capricho por permanecer en él, sino un esfuerzo por enlazar con él, por demostrar, por un lado, que sus ideales y pasiones confluían en la historia, y por otro, que la obra de arte deja de ser un ideal inmutable para penetrar en la existencia de las cosas.

\section{V.1. Las edificaciones, las ruinas y los paisajes en la pluralidad de los escenarios medievales de las "Leyendas"}

Resulta a todas luces revelador el método con que Bécquer cree entender la "idea" que permanece oculta detrás de una ruina o en la tradición. Desde su visión, en los lugares donde la tradición se origina, el historiador debe respetarla y aceptarla, porque entre la historia y la tradición, la "verdad histórica" --la "narración fidedigna" de los hechos, si existe tal cosa-- está mucho mejor representada por la tradición. Esto es así, porque para Bécquer, además, el único medio seguro de acercarse a la historia --transmitida de forma tradicional-- es la intuición artística, que no es otra cosa, señalo, que la capacidad del artista para intuir la verdad ideal, pues sólo la intuición del artista es capaz de penetrar en los misterios de la tradición. En esta preferencia hay una explicación:

¿Por qué al mismo tiempo que se recogen los huesos de un animal antediluviano, no se han de recoger las ideas de otros siglos traducidas en objetos de arte y usos extraños, y diseminados acá y allá como los fragmentos de un coloso, hecho mil pedazos? Esto inmenso botín de impresiones, de pequeños detalles, de joyas extraviadas, de trajes pintorescos, de costumbres características animadas y 
revestidas de esa vida que presta a cuanto toca una pluma inteligente o un lápiz diestro, ¿no creen ustedes como yo que serían de grande utilidad para los estudios particulares y verdaderamente filosóficos de un período cualquiera de la historia? (Carta IV Desde mi celda 411)

Parece obvio, después de una detallada lectura de este fragmento, que Bécquer reafirma la importancia de los vestigios artísticos --y en general, materiales-- y de las costumbres, como reconstructores de la verdadera historia, como elementos que permiten la recuperación del espíritu del pueblo (el Volksgeist), que podría determinarse, entre muchas definiciones, como el afán de conocimiento del hombre para intentar resolver sus inquietudes cognoscitivas más básicas. Así, cabe deducir que para Bécquer las tradiciones, en tanto que narraciones filosóficas populares, tienen una mayor importancia que la historia, por cuanto ésta representa la praxis de esa filosofía al agrupar las acciones que emprende el hombre para hacerse de la verdad. Por ello, desde el comienzo del análisis de este aspecto, he puesto entre comillas, con intención, los conceptos de "verdad histórica" y "narración fidedigna", pues se trata de afirmaciones que deben ser entendidas como relativas. Quizás también por lo mismo, Bécquer prefiera apoyarse en la tradición oral o en los monumentos, edificios o ruinas para reconstruir la historia "a través de una pluma inteligente” o "un lápiz diestro", lo que acentúa la validez de los recursos ecfrásticos que utiliza para expresar su "verdad histórica". La pregunta final de la cita, aunque de forma indirecta, concreta esta valoración de los estudios, que él llama "verdaderamente filosóficos". Por otra parte, en la Historia de los templos de España, a través de los monumentos artísticos, o en los textos fundacionales de su 
teoría artística, es decir, en las Cartas literarias a una mujer o en Desde mi celda, Bécquer deja constancia de este proceder estético.

De acuerdo con Rubén Benítez, "Bécquer cree en la simpatía mágica: su sensación frente a la ruina y aun sus más extrañas fantasías coinciden con la verdad ideal que la ruina encierra" (55).

Al respecto, el propio Bécquer nos dice en "Solar de la casa del Cid en Burgos":

Cuando nos pintan al héroe con tal acento y color que no parece sino que le han visto con sus ojos; cuando, siguiéndole paso a paso, desde la cuna al sepulcro, nos refieren hasta los menores detalles de su vida y nos dicen: 'Aquí nació; allí vivió Jimena; esta es el arca que guardó su palabra, que equivalía a un tesoro; aquellas son las banderas que arrancó a los árabes vencidos...', involuntariamente asoma una vaga sonrisa de incredulidad a los labios; pero poco a poco que se medite, esta ciega fe, este mismo lujo de detalles, hijos de la imaginación del pueblo, revelan poderosamente la vitalidad del personaje, que palpita a través de sus creaciones. (Obras completas 846 )

Debemos deducir de estas palabras, primeramente, que la descripción detallada, casi pictórica, de la tradición es un recurso mucho más eficaz y, si se quiere, poderoso que la simple narración textual, porque, entre otras cosas, nos ayuda a "ver"; y las imágenes, como se ha probado, contribuyen a potenciar un texto, aun cuando se trate de una narración histórica. De ello también se deduce que el enriquecimiento plástico de un referente literario --la tradición narrada mediante 
recursos ecfrásticos-- actúa como el complemento necesario del texto. De ahí que frente al paisaje, o ante los edificios o las ruinas que integran los acentos históricos del mismo, Bécquer acude a la descripción ecfrástica de los elementos compositivos del cuadro: un cambio atmosférico, rico de color y veladuras; un foco de luz que proyecta enigmáticas sombras; o los reflejos y el murmullo del agua. Y esto lo hace con el fin de que el lector-espectador logre evocar con su lectura-visualización un sinnúmero de sensaciones o de "fantásticas ensoñaciones", en las que intervienen, sin duda, un alto componente imaginativo o "imagístico", si se me permite el término.

Así, en "La cruz del diablo" 4 , que se desarrolla en la comarca de Urgellet, en Cataluña, Bécquer nos diseña un breve bosquejo de las ruinas del castillo señorial del Señor de Segre5 ${ }^{5}$ como testimonio de los antecedentes históricos --esto es, verídicos-- de la leyenda: "Aún testifican la verdad de mi relación algunas informes ruinas que, cubiertas de jaramago y musgo, se alcanzan a ver sobre su cumbre desde el camino que conduce a este pueblo" (161). La ruina ya no es, en el caso de Bécquer, un mero recordatorio de la perfección perdida, sino una vía de aproximación a la historia y un instrumento para el conocimiento histórico. Por eso Bécquer la utiliza como "prueba", y la inserta como realidad propia; es decir, tiene una presencia material e histórica que le permite ser, a la vez, una realidad presente, mientras el castillo que la origina es una realidad que pertenece al pasado. Su estado "actual", tal y como nos lo describe, es el resultado de un incendio, que es parte consustancial de la trama. He aquí el detallado cuadro del ruinoso castillo que nos pinta Bécquer: 
El tiempo pasó; comenzaron los zarzales a rastrear por los desiertos patios, la hiedra a enredarse en los oscuros machones y las campanillas azules a mecerse colgadas de las ruinosas almenas. Los desiguales soplos de la brisa, el graznido de las aves nocturnas y el rumor de los reptiles que se deslizaban entre las altas hierbas, turbaban sólo de vez en cuando el silencio de muerte de aquel lugar maldecido; los insepultos huesos blanqueaban al rayo de la luna, y aún podía verse el haz de armas del señor de Segre colgado del negro pilar de la sala del festín. (Leyendas 164)

Con la expresión: "El tiempo pasó", Bécquer deja establecido el espacio temporal entre el pasado, representado por el castillo, y el presente, que representan los vestigios del mismo. Ambos, sin embargo, son exponentes de la historia en uno y otro tiempo. Bécquer manifiesta, por otro lado, su conocimiento y familiaridad con el vocabulario arquitectónico: patios, machones, almenas, pilares, son elementos típicos del castillo medieval, que Bécquer demuestra saber combinar, acertadamente, para lograr la composición deseada. A cada uno de ellos, Bécquer le asigna un elemento plástico que subraya la condición de ruina del castillo, pero que enfatiza, al mismo tiempo, el carácter pictórico del paisaje esbozado: los zarzales, la hiedra, las campanillas y el deterioro de las almenas. Por último, los esqueletos insepultos y las "percepciones auditivas" (soplos, graznidos y el silencio de la muerte) otorgan también al paisaje un carácter de "ruina encantada", escenario propicio para el desarrollo de la historia. Las pinceladas de color, sin embargo, son escasas, salvo el azul de las campanillas (reminiscencia de su adolescencia sevillana) 
y el blanco de los esqueletos, colores, por demás, representativos de los románticos; pero en la "representación"--descrita y “vista"-- se percibe, a través de la respuesta imaginativa que despierta en el lector-espectador, el intenso verdor de la invasiva vegetación, quizás como el único ejemplo de vida en medio del sobrecogedor paisaje.

A pesar de que Bécquer recurre a una exactitud arqueológica para el tratamiento de las estructuras arquitectónicas y elementos decorativos --en esta y otras leyendas-- se permite una mayor libertad en la ambientación y ubicación de las mismas, sobre todo en el uso del color y en la pintura de las atmósferas. Estos recursos son los que terminan por definir el tono del paisaje; pero es la ruina, en tanto que testimonio físico del pasado --y como tal parte de la historia--, la que deviene instrumento para el conocimiento histórico. Bécquer se sirve de ella para elaborar muchos de los relatos legendarios, pues devienen el fundamento necesario sobre el que tejer la trama de un presente histórico sobre hechos que han ocurrido, muchas veces, en un remoto pasado. Sobre esta peculiaridad con relación a la ruina y su forma de relacionarla con el tiempo, Jiménez Blanco ha señalado lo siguiente: "En lugar de contemplar las ruinas como inefables epifanías de una borrosa gloria pasada, o como ominosas metáforas de un inexorable y desastroso futuro, los arqueólogos-anticuarios comenzarán a verlas con un ferviente deseo de reducirlas a términos presentes, de situarlas en una coordenada temporal precisa" (88).

Esto es, precisamente, lo que hace Bécquer: o bien reconstruye los edificios que dieron lugar a esas ruinas, integrando o no su destrucción en la trama de la leyenda, pero situándola en su propio contexto histórico --esto es, en su "presente"-- 
; o bien se vale de su condición actual, mediante la concreción de su estado, a fin de ambientar unos hechos que ocurren en una realidad presente. Este recurso de Bécquer hace que el lector-espectador se mueva en escenarios temporales disímiles, que pueden ser tanto pasados como presentes; pero como Bécquer utiliza a un narrador --casi siempre en una corta introducción-- para narrar la leyenda pasada, desde el presente, en realidad Bécquer alude a dos momentos del pasado, uno anterior al otro.

La ruina como motivo iconográfico, más que como género pictórico, aparece ya en el siglo XVI, pero su trayectoria culmina en el Romanticismo. Durante estos años, la ruina adopta diversidad de expresiones, aunque prevalece el sentimiento de melancolía como expresión del vacío, de la desesperanza, de la muerte, pero sobre todo de la incapacidad de comprensión; pero por estar, precisamente, vacía de contenido, de significado, incita a la nostalgia, y es, al mismo tiempo, una invitación a imaginar. En este sentido, se ha manifestado Vidal Oliveras: "Las ruinas se expresan como fragmentos, partes inconexas que, como una serie de anécdotas sin continuidad ni relación, escapan a una visión de conjunto o relato, a un saber organizado y racional. Por esa razón incitan a la imaginación, para que ésta recomponga los fragmentos del rompecabezas que faltan" (2). En ese sentido, Bécquer reta al lector-espectador a reconstruir lo que falta de esas ruinas, y lo hace porque la dimensión onírica de éstas son un espacio de creación para la fantasía y la imaginación del lector. Pero junto a esta fantasía e imaginación se encuentra también el elemento fantasmagórico de las Leyendas: "Las casas deshabitadas, los castillos abandonados, los palacios devastados por el paso del tiempo, están 
habitados por fantasmas que son los deseos, los miedos y las ansiedades que el presente proyecta en el pasado, o mejor, en los vestigios del pasado" (Vidal Oliveras 2). Es sugerente el valor metafórico que Vidal le concede a las ruinas, porque acentúa el carácter de paisaje ideal, en el que Bécquer las inserta como elementos iconográficos de la composición pictórica, pero también como elementos de una fuerte carga simbólica.

Esta visión se enmarca, además, en la idea expuesta por Henares Cuéllar y Calatrava, de que "si la historia explica la marcha monumental de los imperios, los monumentos a su vez pueden corregir la historia" (315). Además, es precisamente en el Romanticismo español cuando surge el planteamiento de una arqueología de base nacional y espiritual. En ese sentido, se manifiesta Manuel de Assas en un artículo, publicado en El Renacimiento: "Sobre los estudios arqueológicos en España". Al propio de Assas también debemos la afirmación de que el eje del discurso historicista lo va a constituir la arqueología medieval, como se desprende de sus escritos. De acuerdo con Henares Cuéllar y Calatrava, "[e]l rechazo de la iconografía arcádica, incompatible con 'este siglo de hierro', y una propuesta esencialmente heroica ('Pelayo ha reemplazado a Rómulo, las catedrales góticas a los templos corintios, Jesucristo a Júpiter'), fundamentan las bases de una nueva arqueología" (316). De Assas, según ya hemos acotado antes, mantuvo una estrecha colaboración con Bécquer para su proyecto de la Historia de los templos de España. Muchas de sus ideas tuvieron que influir, por fuerza, en la obra de Bécquer, sobre todo en las Leyendas.; y, de hecho, se perciben sus ecos. Por otro lado, la idea de una exaltación de una arquitectura nacional, la gótica, como parte de la valoración 
historicista de las artes nacionales, ya contaba con algunos antecedentes en los trabajos de A. de Zabalea. Los términos que se dibujan en este período están muy bien definidos: arqueología, nación y estilo, frente al clasicismo ecléctico. Entre estas coordenadas se desenvuelve Bécquer.

Por ello, en "La ajorca de oro ${ }^{6}$ (Leyenda toledana)", lo más significativo para nuestro enfoque histórico-artístico es, sin duda, la descripción de la catedral gótica de Toledo, y muy particularmente la figura de la virgen de la capilla del Sagrario ${ }^{7}$ y sus joyas, descritas por algunos destacados escritores como Théophile Gautier y el Vizconde de Palazuelos ${ }^{8}$. En 1845, Gautier publica su versión final de Voyage en Espagne, fruto de un largo viaje realizado a este país, en 1840, donde nos hace, en el capítulo X, una brillante descripción de los tesoros que abriga el sagrario. A su vez, el Vizconde de Palazuelos elabora una guía para los viajeros de la época, dentro del gusto romántico por todo lo exótico y antiguo, en la que también destaca las joyas del Sagrario. No podemos afirmar, categóricamente, que estas descripciones hayan sido consultadas por Bécquer, pero tampoco sería disparatado suponerlo, toda vez que la obra de Gautier, por ejemplo, pudo resultarle de fácil acceso en la biblioteca de su madrina, poseedora de una vasta colección de obras de la literatura francesa.

De acuerdo con Pascual Izquierdo, "eran dos y no una, las ajorcas o manillas de la Virgen en 1869" (189). En todo caso, la existencia corroborada de estas ajorcas le otorga a la leyenda cierto grado de "veracidad histórica", lo que hace que pudiéramos estar ante "recreaciones arqueológicas puras", en cierto sentido. Además, los periódicos de la época reflejan un intento de robo en la catedral. Es decir, Bécquer se vale de ciertos hechos o elementos verídicos para elaborar la 
leyenda, aunque interpretados o (re)creados en otros contextos. Es obvio, por otra parte, el eco en esta leyenda de las descripciones de la Historia de los templos de España, cuyo capítulo sobre Toledo fue abordado desde presupuestos históricoartísticos, tal y como prueban los documentos y apuntes artísticos realizados por Bécquer, y el propio volumen dedicado a Toledo.

Bécquer trata la luz en estos cuadros de una forma que nos recuerda a un artista sevillano muy admirado por su familia y por él mismo. Me refiero a Esteban Murillo $^{9}$, en cuyas obras el verdadero protagonista es la luz. Murillo emplea en muchas de sus obras, sobre todo en aquéllas de tema religioso, una luz dorada que provoca un marcado efecto atmosférico, pero que difiere de la luz de Lorrain en cuanto a los fuertes contrastes de luz y sombra que otorgan un gran dinamismo a la composición, como es típico de la estética barroca, dentro de sus convenciones sobre el valor del claroscuro en la composición. La Virgen del Sagrario que Bécquer nos pinta --dentro de ciertas características de suntuosidad y riqueza del arte barroco-- parece remitirnos a las inmaculadas "triunfantes" de Murillo:

Ayer estuve en el templo. Se celebraba la fiesta de la Virgen: su imagen colocada en el altar mayor sobre un escabel de oro, resplandecía como un asca de oro; las notas del órgano temblaban, dilatándose de eco en eco por el ámbito de la iglesia... No sé por qué mis ojos se fijaron en un objeto; aquel objeto es la ajorca de oro que tiene la madre de Dios en uno de los brazos. (189)

Luego de esta breve presentación, Bécquer se centra en los efectos luminosos que cree admirar María Antúnez, la protagonista, en la joya que lleva la imagen de la 
Virgen: "Las luces del altar, reflejándose en las mil facetas de sus diamantes, se reproducían de una manera prodigiosa. Millones de chispas de luz, rojas y azules, verdes y amarillas, volteaban alrededor de las piedras como un torbellino de átomos de fuego" (189). La misma protagonista nos pinta a una Virgen humanizada, como las de Murillo: "Veía cruzar una mujer morena y hermosa que llevaba la joya de oro y pedrería, porque no era ya la Virgen que yo adoro..., sino una mujer" (190). La exagerada luminosidad de la joya incide en su intención de representar la grandeza y victoria de la Virgen. Por otra parte, las modelos que Murillo utilizó para sus imágenes eran mujeres del pueblo, muy jóvenes, lo que contribuyó, sin duda, a humanizar los rasgos de la Virgen; hecho que, por otra parte, acrecentó su fama de pintor del pueblo entre los españoles. Bécquer se apropia, sobre todo, del llamado "estilo cálido" de Murillo, en el que predominan las tonalidades luminosas y los colores vibrantes. La fuerza plástica es, justamente, el rasgo dominante del primer gran ciclo de Murillo, cuyo trasfondo ideológico es la respuesta pictórica del devoto ambiente de la Contrarreforma, muy en línea con la obra de Chateaubriand --uno de los pilares fundamentales de la rehabilitación romántica de la historia-- y con la del propio Bécquer. Además, para los románticos españoles, Murillo es "el pintor del cielo" y "el Rafael español”, de ahí que, con la utilización de Murillo como referente, Bécquer se muestra consecuente con sus preferencias pictóricas --y hasta ideológicas--, reflejadas, en este caso, en la Carta IX de Desde mi celda, en la que se refiere, en estos términos, a la Virgen de Veruela:

Yo he visto, pintadas por nuestros más grandes artistas, algunas de esas místicas escenas; yo he visto, y usted habrá visto también, a la 
misteriosa luz de la catedral de Sevilla, uno de esos colosales lienzos en los que Murillo, el pintor de las santas visiones, ha intentado fijar, para pasmo de los hombres, un rayo de esa diáfana atmósfera en que nadan los ángeles como en un océano de luminoso vapor, pero allí es necesaria la intensidad de las sombras en un punto del cuadro para dar mayor realce a aquel en que se entreabren las nubes como con una explosión de claridad; allí, pasada la primera impresión del momento, se ve el arte luchando con sus limitados recursos para dar idea de lo imposible. ( Obras completas 450)

El comentario resulta sugerente en muchos sentidos, toda vez que en Desde

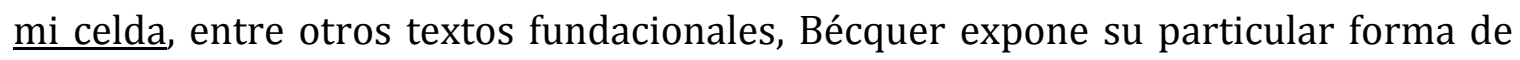
expresión literaria, en la que, como se comprueba, recurre a lo visual como complemento indispensable de su discurso. Por otra parte, la insistencia en la expresión "yo he visto", que duplica, y en "usted habrá visto también", parece sugerirnos la idea de que es absolutamente necesario que el lector "vea" en sus textos, que sea espectador, a la par que lector; y esto se hace aquí particularmente evidente.

Bécquer aborda, además, el tratamiento de la luz y del claroscuro, como lo haría un pintor. La luz que utiliza cae de manera natural, es decir, baña al espacio conforme a la dirección marcada. Pero es, sobre todo, la oscuridad, y su relación con la luz, lo que crea la ilusión de profundidad y de realidad; por eso el claroscuro es el contrapunto necesario para realzar la luz, una luz tan intensa, casi sobrenatural por momentos, que para Bécquer es un efecto de "la luz dentro de la luz". Así, nos dice 
nuevamente, ante la imagen de la Virgen de Veruela: "Yo me figuro algo más, algo que no se puede decir con palabras ni traducir con sonidos o con colores. Me figuro un esplendor vivísimo que todo lo rodea, todo lo abrillanta; que, por decirlo así, se compenetra en todos los objetos y los hace aparecer como de cristal, y en su foco ardiente, lo que pudiéramos llamar la luz dentro de la luz" (Desde mi celda 450). De nuevo Bécquer apela a su imaginación pictórica --y a la del lector-espectador-- para reproducir pictóricamente esa "luz de Murillo" que, según argumenta, es imposible recrear con palabras o sonidos. De hecho, Bécquer nos muestra la escena, más que decirla, tratando de establecer una relación analógico-referencial con lo descrito.

En la descripción de la catedral de Toledo ${ }^{10}$, que ocupa el capítulo final, Bécquer vuelve, nuevamente, a pedirnos que "imaginemos" el cuadro que nos pinta: “iLa catedral de Toledo! Figuraos un bosque de gigantescas palmeras de granito que al entrelazar sus ramas forman una bóveda colosal y magnífica, bajo la que se guarece y vive, con la vida que le ha prestado el genio, toda una creación de seres imaginarios y reales" (191). En esta primera estrofa, Bécquer compara las columnas de granito con las palmeras de un bosque, bajo cuyos arcos y bóvedas, transmutados en ramas, se halla la más hermosa creación de obras escultóricas. El símil con la naturaleza es relevante en más de un sentido, por cuanto se buscaba en ésta la expresión más completa de la perfección artística, como parte de la concepción aristotélica de la imitación a la naturaleza --la mímesis--como finalidad última de la creación artística.

En el segundo párrafo, Bécquer apela a los efectos dramáticos, casi violentos, de luces y sombras, propios del barroco de Rembrandt, otro de sus pintores 
favoritos, o del mismo Murillo de la "etapa tenebrista", pues se percibe una forzada iluminación en el cuadro, que es más tenebrista ${ }^{11}$ que barroca, en su sentido español, es decir, en el uso dramático de la técnica del claroscuro, que Bécquer utiliza en el interior de la catedral. De nuevo se nos pide "imaginar": "Figuraos un caos incomprensible de sombra y luz, en donde se mezclan y confunden con las tinieblas de las naves los rayos de colores de las ojivas, donde lucha y se pierde con la oscuridad del santuario el fulgor de las lámparas" (191).

Por último, Bécquer nos vuelve a pedir imaginar, por medio de una serie de comparaciones, "un mundo de piedra, inmenso como el espíritu de nuestra religión, sombrío como sus tradiciones, enigmático como sus parábolas, y todavía no tendréis una idea remota de ese eterno monumento del entusiasmo y la fe de nuestros mayores, sobre el que los siglos han derramado a porfía el tesoro... de sus artes" (191).

Aquí, sin embargo, se evidencia esa "incapacidad" del espectador por reproducir la obra de arte, recurso que tantas veces utiliza Bécquer en su obra. Aunque si bien en los dos párrafos anteriores, éste accede a reconocer en el lectorespectador la capacidad para reconstruir la obra (el objeto visual, en definitiva), en este párrafo se concreta que "no tendremos una idea remota" para hacerlo, por mucho que lo imaginemos --o lo pintemos-- parece decirnos. No debemos inferir de ello una contradicción de sus capacidades ecfrásticas. Antes bien, se trata de un recurso para ponderar la extrema belleza del templo, y lo hace desde el supuesto de que no lo podemos imaginar. Ya en Desde mi celda, en la carta IV, Bécquer "parece poner en duda", incluso, la capacidad del "pincel": "Adonde no alcanza, pues, ni la 
paleta del pintor con sus infinitos recursos, ¿cómo podrá llegar mi pluma sin más medio que la palabra, tan pobre, tan insuficiente?" (413). Pero este recurso es, a todas luces, engañoso; diría, más bien, que es parte de su --a veces, complejo--estilo de abordar nuevas formas con la intención de hacernos "ver", que es parte, además, de su modelo intertextual o, mejor, intermedial, pues sólo "parece poner en duda" esa capacidad, para luego desplegar todo un universo de imágenes sensoriales con las que construye su intermedialidad ecfrástica. Ni siquiera esa posible incapacidad para reproducir o representar la realidad podía limitar el espacio de la invención ecfrástica.

Hay en Bécquer una fascinación por el desgaste y derrumbe de las obras del pasado, a causa del paso del tiempo --visto como algo implacable que destruye todo lo que toca--, que se traduce en una casi constante pintura de ruinas. Al igual que para muchos románticos, los vestigios son, también para Bécquer, la expresión de un rescate de las virtudes, del saber y del espíritu del pueblo español; una expresión, por otro lado, de su historia y de su quehacer artístico. La huida de Bécquer hacia el medioevo, debe ser interpretada, además, como un intento de revitalización de lo nacional-cristiano, puesto que fue en la Edad Media cuando comienza a articularse la idea de un estado español, cuyo eje sería la religión cristiana, como él mismo anuncia en la introducción a la Historia. En este sentido, el discurso de Bécquer se ajusta a las exigencias del historicismo de Chateaubriand, con su constante tono elegíaco, su reivindicación de lo medieval, y su visión del arte como algo esencialmente espiritual. En ese contexto, Bécquer aborda nuevamente el tema de las ruinas en "El monte de las ánimas ${ }^{12}$ (Leyenda soriana)". Esta vez, se trata de un 
monasterio de la Orden de los Templarios y su capilla, que aparecen representados como edificios o como ruinas, en función del espacio temporal en que se desarrolla la narración.

Pareciera en esta leyenda que Bécquer se hubiera inspirado en la obra del artista alemán, Caspar David Friedrich: "Paisaje con ruina de un templo" (1802), pues lo primero que describe Bécquer es la ruina de una capilla gótica, insertada en un paisaje de decidida inspiración medieval. Por otro lado, el paisaje con elementos históricos le sirve a Bécquer como el escenario ideal para narrar la tradición, seguido de algunas percepciones acústicas: “Dentro de poco sonará la oración en los Templarios, y las ánimas de los difuntos comenzarán a tañer sus campanas en la capilla del monte" (198). Bécquer esboza, a manera de antecedente, una suerte de "historia anterior" sobre la animosidad entre los nobles castellanos de Soria y los Templarios, ocupantes del monasterio, que es importante como parte de su interés en las "recreaciones arqueológicas puras", esto es, en la reconstrucción del pasado, pero también como el necesario soporte histórico que reclamaba la tradición. Sin embargo, en la descripción arquitectónica, Bécquer se vale únicamente de brevísimas pinceladas aisladas: una "alta chimenea gótica... o los emplomados vidrios de las ojivas del salón" (200), con la intención de situar el relato en un deseado escenario medieval, como correspondía, además, al carácter historicista de la narración. Bécquer logra, por otra parte, unir el estudio del arte medieval español al de su geografía, su cultura y su política, acentuando así su singularidad histórica.

Pero lo que estructura la descripción pictórica --el objeto visual-- del castillo de Montegut no son, desde luego, estas breves pinceladas. Bécquer recurre a un rico 
entramado de efectos acústicos, integrantes de un escenario sonoro de gran plasticidad. Estos efectos son los que conforman, en definitiva, las necesarias intermedialidades para describir al lector --valga la paradoja-- la pintura arquitectónica. Por eso, en lugar de "mira", "ves" o "figuraos", entre otros de sus recursos que apelan a la vista, Bécquer acude al "oído" del lector, en tanto que "oyente-destinatario" del texto, a fin de que éste pueda componer el cuadro, pero lo hace aquí de forma indirecta. Para ello, se vale de un personaje --dentro del relato ficcional, tal y como hace también con los efectos visuales-- al que se le pregunta directamente: “¿Oyes? Las campanas doblan, la oración ha sonado en San Juan del Duero" (202). Iguales recursos acústicos parece utilizar para la "pintura sonora" del castillo:

Las puertas de alerce del oratorio habían crujido sobre sus goznes con un chirrido agudo, prolongado y estridente. Primero unas y luego las otras más cercanas, todas las puertas... iban sonando por su orden; éstas con un ruido sordo y grave, aquéllas con un lamento largo y crispador. Después, silencio; un silencio lleno de rumores extraños, el silencio de la medianoche; con un murmullo monótono de agua distante, lejanos ladridos de perros, voces confusas, palabras ininteligibles, ecos de pasos que van y vienen, crujir de ropas que se arrastran, suspiros que se ahogan, respiraciones fatigosas que casi se sienten, estremecimientos involuntarios que anuncian la presencia de algo que no se ve y que, no obstante, se nota su presencia en la oscuridad. (204) 
Sobre este cuadro sonoro, en el que se repite convenientemente el término "silencio", muy probablemente como contrapunto del sonido y antecedente de la acción siguiente, Bécquer parece pintarnos la inmensidad del espacio interior del castillo, pero para ello recurre a una combinación de "realidad" y "escenografía sonora". Ya hemos visto en las écfrasis pictóricas de Bécquer que la yuxtaposición de luces y sombras --el claroscuro, a veces con connotaciones tenebristas-- incide en el cuadro pictórico como recurso de ambientación de la tradición. Aquí, el silencio y el ruido parecen crear el clima propicio a la narración. Utilizo, pues, el término de "pintura sonora" ante el hecho indiscutible de que Bécquer nos hace leer y escuchar, pero lo hace, como es característico en él apelando a nuestra imaginación, y con ella al recurso "imagístico", con lo cual el proceso de "ver" no deja de estar presente. Tenemos, pues, en ese proceso, a un lector que "escucha", pero que "ve" al mismo tiempo, es decir, pasa a ser un lector-oyente-espectador activo, a la luz de la teoría de la recepción, y parte importante del proceso de concretización de un texto en el acto de lectura. Este aspecto es, quizás, uno de los grandes aportes creativos de esta leyenda, por cuanto esta reafirmación multisensorial en la que se combinan vista y oído, aunque éste último apele, en definitiva, a la vista, confirma la naturaleza plástica de estas narraciones.

En el caso de "Los ojos verdes"13 --quizás la leyenda que evidencia, mucho más que ninguna otra, el papel del lector activo en su lectura-- la función recreativa de la imagen por parte del lector se apoya, fundamentalmente, en la vista, aunque están presentes las percepciones auditivas a manera de pinceladas acústicovisuales. Esta leyenda se inicia con una suerte de exordio: 
Hace mucho tiempo que tenía ganas de escribir cualquier cosa con este título. Hoy, que se me ha presentado la ocasión, lo he puesto con letras grandes en la primera cuartilla de papel, y luego he dejado a capricho volar la pluma. Yo creo que he visto unos ojos como los que he pintado en esta leyenda. No sé si en sueños, pero yo los he visto. De seguro no los podré describir tal cual ellos eran: luminosos, transparentes como las gotas de la lluvia que resbalan sobre las hojas de los árboles después de una tempestad de verano. De todos modos, cuento con la imaginación de mis lectores para hacerme comprender en éste que pudiéramos llamar boceto de un cuadro que pintaré algún día. (207-8)

La introducción nos aclara algunos recursos importantes. Primero, el texto apela a nuestra imaginación --también como destinatarios-- para completar la descripción de unos ojos que el autor se confiesa incapaz de describir con palabras; por lo tanto, nos invita a "verlos", puesto que los ha "pintado", mientras continuamos la lectura de la écfrasis que ha elaborado, comparando los ojos con las gotas de lluvia que resbalan por las hojas de los árboles; otra referencia cromática que, por contigüidad de significados, es decir, por su connotación metonímica, nos remite nuevamente al color verde de las hojas. En ese sentido, "la cuartilla de papel" sobre la que ha dejado "a capricho volar la pluma" (136) deviene el lienzo o soporte sobre el que se superponen tanto el texto descriptivo ecfrástico como la imagen que completamos --personaje y lectores-- como destinatarios activos. Podría parecer, a primera vista, que Bécquer apela a la mente directamente y no a los sentidos para 
"ver". Pero, obsérvese que al final nos advierte que sólo se trata de un boceto y, por lo tanto, de una imagen inacabada, incapaz de transmitirnos una idea completa de la luminosidad y transparencia de los ojos, lo que se justifica por su carácter de boceto, es decir, de dibujo resuelto esquemáticamente --y como tal inconcluso-- de una obra que promete "pintar" algún día. El cuadro final vendría a completar, entonces, la descripción que sí llegaría al lector a través de los sentidos. Si volvemos a las líneas iniciales, podría afirmar, con la intención y los recursos pictóricos ya definidos, que Bécquer hacía tiempo que quería "pintar-escribir" cualquier cosa con ese título. Luego, ha esbozado los primeros apuntes sobre "el lienzo-cuartilla" y, por último, ha dejado volar "el pincel-pluma" sobre éstos. No hay ninguna duda sobre la posibilidad, no ya de intercambiar un elemento por otro, sino de usar todos estos elementos a un mismo tiempo.

Sobre estos aspectos --en el marco de la comparación entre pintura y literatura-- se han pronunciado dos críticos. John Hughes afirma que "la razón por que las descripciones ejercen una impresión más vívida en los lectores comunes que cualquier otra de las partes del poema [Se refiere a las descripciones plásticas en un poema] es porque están formadas por ideas sacadas de los sentidos" (45-46). En el extremo contrario, encontramos a John Jacob Breitinger, quien sostiene que la ventaja de la poesía sobre la pintura es que "consiste en palabras que son 'signos artificiales de conceptos e imágenes', y que por tanto afectan a la mente directamente y no a través de los sentidos" (Cit. por Schweizer 25).

Basado en estos comentarios, podríamos concluir que las imágenes son directas porque derivan de los sentidos, pero las ideas --si se expresan mediante la 
palabra-- son todavía más directas porque, a diferencia de los objetos sensibles, contienen lo que ya está en la mente. Por lo tanto, la utilización de imágenes visuales o acústicas, "narradas" a través de la palabra, se reafirman y fortalecen, lo que incrementa sustancialmente el valor plástico de aquéllas, precisamente, porque su significado ya está conformado en la mente.

Más adelante, aparece Íñigo, en su doble papel de destinatario-espectador dentro de la trama textual, a quien Bécquer muestra el cuadro descriptivo ecfrástico, y con éste, nos lo muestra también a nosotros, en tanto que destinatariosespectadores, aunque fuera del texto, apelando a uno de sus recursos habituales: nos invita a "leer" y "ver" el cuadro de forma simultánea, a la manera de lo que Jakobson llamó "traducción o transmutación intersemiótica" (428). Analicemos el diálogo entre los dos personajes de la trama:

¿Tú no conoces aquel sitio? Mira: la fuente brota escondida en el seno de una peña, y cae, resbalándose gota a gota, por entre las verdes y flotantes hojas de las plantas que crecen al borde de su cuna. Aquellas gotas, que al desprenderse brillan como puntos de oro y suenan como las notas de un instrumento, se reúnen entre los céspedes y, susurrando, susurrando, con un ruido semejante al de las abejas que zumban en torno de las flores, se alejan por entre las arenas y forman un cauce, y luchan con los obstáculos que se oponen a su camino, y se repliegan sobre sí mismas, y saltan, y huyen, y corren, unas veces con risas; otras con suspiros, hasta caer en un lago. En el lago caen con un rumor indescriptible: lamentos, palabras, nombres, cantares, yo no sé 
lo que he oído en aquel rumor cuando me he sentado solo y febril sobre el peñasco a cuyos pies saltan las aguas de la fuente misteriosa, para estancarse en una balsa profunda, cuya inmóvil superficie apenas riza el viento de la tarde. (138-9)

En este caso, el imperativo verbal "Mira" constituye una invitación a la visualización del "cuadro", tal y como el artista se lo presenta a Íñigo. El hecho de que éste no conozca el lugar, justifica la descripción ecfrástica del paisaje idílico con elementos que conforman un particular estilo de pintura de paisaje, que toma elementos de la estética pictórica romántica, la prerrafaelista y la simbolista. La escena, como se aclara posteriormente, tiene lugar "al despuntar la mañana" (139); esto es, al amanecer, que al igual que el crepúsculo, aportan una gama cromática luminosa y muy efectista al cuadro romántico, a la manera de Claude Lorrain o Caspar David Friedrich. Además, Bécquer incorpora, junto a los elementos cromáticos de gran plasticidad, las sonoridades musicales --Es decir, imágenes sonoras-- que complementan las imágenes visuales. El color verde --el color de los ojos-- se subraya de forma directa mediante la mención a "las verdes y flotantes hojas de las plantas", y de forma indirecta mediante la mención a los "céspedes", lo que constituye un recurso que Bécquer incorpora de forma equilibrada desde el comienzo mismo de la leyenda.

El final de la misma se desarrolla en un momento de cambio atmosférico, en el crepúsculo, antecedente a nivel simbólico de la muerte del protagonista, que Bécquer expone de la manera siguiente: "El sol había traspuesto la cumbre del monte; las sombras bajaban a grandes pasos por su falda; la brisa gemía entre los 
álamos de la fuente, y la niebla, elevándose poco a poco de la superficie del lago, comenzaba a envolver las rocas de su margen" (213-4). La atmósfera del cuadro pintado es envolvente y vaporosa como en una pintura de Turner, pero ideal como complemento emocional de la acción. Bécquer, además, nos hace visualizar el avance de Fernando hacia el borde del lago, en cuyas aguas habita una suerte de ondina o espíritu de mujer, verdadero émulo de la "Ofelia" de Millais, una obra prerrafaelista que pudo haber inspirado a Bécquer, dada su atracción por el personaje de Shakespeare, al que pintó en varias ocasiones, como prueban los dibujos que han subsistido hasta nuestros días y las innumerables menciones del personaje en su prosa.

En la obra de Millais, Ofelia flota sobre el agua --rodeada de plantas y flores-con la que parece estar diluida a través de transparencias y veladuras, que utiliza el artista en el tratamiento del personaje, tal y como la describe Bécquer: Aquí, al igual que Íñigo, Bécquer se vale de la ondina para invitar a Fernando a que "vea" el fondo del lago, y al hacerlo, nos invita a "ver" el mismo cuadro descriptivo, como espectadores-destinatarios:

¿Ves?, ¿Ves el límpido fondo de este lago? ¿Ves esas plantas de largas y verdes hojas que se agitan en su fondo?... Ellas nos darán un lecho de esmeraldas y corales..., y yo..., yo te daré una felicidad sin nombre, esa felicidad que has soñado en tus horas de delirio y que no puede ofrecerte nadie... Ven; la niebla del lago flota sobre nuestras fuentes como un pabellón de lino...; las ondas nos llaman con sus voces incomprensibles. (215) 
La plasticidad de la descripción está expresada en términos de color, prevaleciendo el color verde: las "hojas del fondo" y las "esmeraldas", como una suerte de contigüidad cromática con el color de los ojos, lo que subraya el poder evocador de las imágenes visuales, tal y como ha hecho Bécquer desde la introducción. La niebla envolvente --influencia de Lorrain y Turner, entre otros posibles referentes-- contribuye a cubrir la pintura con una deseada imprecisión pictórica con que finaliza la escena, pero desdibujando a los personajes --las líneas del dibujo-- y con éstas las formas. El escenario pictórico se convierte, así, en una suerte de ensoñación en la que prima sólo el color, aunque resuelto pictóricamente por medio de una masa imprecisa de formas, a la manera de Turner.

En "Los ojos verdes", por otra parte, la referencia a los marqueses de Almenar -una alusión histórica a la plaza del mismo nombre, que fue bastión árabe antes de la ocupación castellana de la línea del Duero-- se inscribe dentro de las bases de una comprensión nostálgica del pasado, que Bécquer había iniciado con el proyecto de la Historia.

De acuerdo con Pascual Izquierdo, refiriéndose al bastión árabe: “su castillo fronterizo, existente desde el siglo XIII, perteneció a los condes de Gómara” (Leyendas 208). Este hecho sitúa el escenario histórico en la Reconquista, etapa en que se sitúan algunas de los relatos legendarios de Bécquer. El aspecto "contextualizador y el caracterizador, [son] valores que se aplican, especialmente, a lo que se refiere a la cultura islámica” (Regueiro Salgado 182). Esto es así, porque al contextualizar el escenario en esa etapa, Bécquer traslada al lector a ese Oriente andaluz arabizado, asociado a la Sevilla de su infancia y adolescencia, que le resulta, por demás, el escenario más familiar y 
apropiado, y como tal, el espacio temporal idóneo por sus referencias a lo exótico y a lo fantástico.

Con iguales referentes a "La ondina del lago azul” (De Gómez de Avellaneda), de acuerdo con la afirmación de Gulsoy (99), Bécquer nos presenta "El rayo de luna ${ }^{14}$ (Leyenda soriana)". En esta leyenda, Manrique --muy probablemente un alter ego de propio Bécquer-- es el poeta soñador entregado a la soledad y a las ensoñaciones, a los paseos por las ruinas solitarias, a las evocaciones, y a la búsqueda de la belleza ideal, lo que origina no pocas descripciones ecfrásticas de los paisajes observados durante estos paseos. La luz --un elemento de gran importancia dentro de la estética becqueriana--juega un papel preponderante en la narración de esta leyenda, pues interviene en una serie de imágenes de gran contendido plástico: la luz de la luna reflejada en el agua, a través de las hojas o en la iluminación del ventanal gótico.

De nuevo, nos hallamos ante un cuadro historicista con un escenario perfectamente determinado en el tiempo y en el espacio, como destaca, por un lado, la aclaración del origen "soriano" de la leyenda, y, por otro, la decidida ambientación medieval dada por el reloj del Postigo, las murallas medievales, la ermita de San Saturio y las fortalezas de los templarios, entre otros referentes arquitectónicos que sitúan la leyenda en el período medieval. En esto, Bécquer responde a lo más "típico", en el sentido positivo del término; esto es, en la combinación de paisaje y edificación gótica;en el tratamiento del color, que se manifiesta por un profundo contraste entre la ruina y el paisaje ambiental, a veces montañoso; en el punto de vista, tanto el de los personajes de la tradición, como el nuestro, en tanto que 
lectores-espectadores; en la figura humana que puede resultar desproporcionada con relación al paisaje. En general, nos puede remitir a las características esenciales del romanticismo pictórico; tardío, en el caso de Bécquer, un escritor que, en términos cronológicos, es posromántico y pre-simbolista, como es sabido. Analicemos el siguiente ejemplo de paisaje soriano en que las ruinas juegan un papel de vestigio histórico-artístico:

Sobre el Duero, que pasaba lamiendo las carcomidas y oscuras piedras de las murallas de Soria, hay un puente que conduce de la ciudad al antiguo convento de los templarios, cuyas posesiones se extendían a lo largo de la opuesta margen del río. En la época a que nos referimos, los caballeros de la orden habían ya abandonado sus históricas fortalezas; pero aún quedaban en pie los restos de los anchos torreones de sus muros; aún se veían, como en parte se ven hoy, cubiertos de hiedras y campanillas blancas, los macizos arcos de su claustro, las prolongadas galerías ojivales de sus patios de armas, en las que suspiraba el viento con un gemido, agitando las altas yerbas. (238)

Bécquer parece querer atrapar con su lente algo de lo que va desapareciendo, de una realidad destruida por el tiempo; y las ruinas son un fiel exponente de ello, porque representan un símbolo de caída, destrucción y muerte, de algo que tuvo utilidad y función, pero que sólo existen como mudos testigos del pasado, un pasado en el que Bécquer quiso indagar con una visión nostálgica, como respuesta romántica de su sensibilidad artística y del interés de los pintores andaluces, en 
general, por reflejarlas en sus obras. La presencia del espectador ante la ruina esboza, por otro lado, múltiples sentimientos: desolación, agonía, muerte, que se derivan de su condición física, pero también, en un nivel de introspección, nos puede indicar reflexión y belleza, como Bécquer lo sugiere. No hay duda, por otro lado, de que el factor religioso, herencia del Génie du Christianisme de Chateaubriand, también se refleja en el espíritu de estos relatos legendarios, de ahí el papel destacado de la religión, como expresión de la tradición, en muchas de las Leyendas.

Si nos detenemos ante los elementos de la composición del cuadro, veremos que Bécquer resuelve la misma siguiendo las directrices de Poussin y Lorrain. En el fondo, coloca al río Duero que bordea las murallas de la ciudad, pero del que Bécquer no ofrece detalles por encontrarse detrás, en un plano alejado. A un lado, Bécquer sitúa el puente, al que tampoco detalla --quizás por carecer de importancia en la trama-- que une la ciudad con las antiguas posesiones de los Templarios en la margen opuesta. En esa margen, muy posiblemente en un primer plano o cerca de él, destacan las ruinas de las fortalezas --las verdaderas protagonistas del cuadro-invadidas, como cabe esperar, por la abundante vegetación, que se convierte así en un elemento plástico de gran vitalidad, pues acentúa, a nivel metafórico, el contraste entre vida y muerte; pero a nivel pictórico también contribuye a acentuar el contraste de color. En los dos últimos párrafos de la cita, Bécquer abunda en las características de esta vegetación invasiva, detallando los tipos de plantas, sus flores y colores. Pero observemos que salvo el color blanco de las campanillas en el segundo párrafo --un color que, junto al azul representan los colores más representativos del Romanticismo y del Simbolismo-- no hay otra referencia 
concreta a color alguno; y sin embargo, tenemos ante nosotros un espléndido y colorido paisaje. Bécquer ha apelado, sobre todo, a nuestra imaginación y al valor referencial de estos elementos compositivos sin mencionarlos ni pedírnoslo formalmente. Aquí no ha habido espacio para sus recurridos términos de "imaginaos", "mira" o "figuraos", ya que sólo nos permite hacer nuestra lectura a un nivel totalmente imaginativo. Así, partiendo únicamente de nuestra visualización de los referentes compositivos del cuadro, somos capaces de recrear los colores de estos elementos, sean éstos las oscuras murallas, las piedras del puente, el río Duero, o el copioso abanico de matices y tonos de la vegetación, y hasta el cielo no mencionado; porque al nombrar las ruinas, las distintas plantas o los árboles, acuden a nosotros, de inmediato, sus correspondientes referentes cromáticos con los que podemos recrear el colorido del paisaje. Esto exige de nosotros, sin duda, una participación activa como lectores-espectadores, pero también una cierta sensibilidad artística.

Algo que no pasa inadvertido en estas descripciones ecfrásticas de Bécquer es la recreación arqueológica en estos paisajes de la obra de Calude Lorrain y Nicholas Poussin, dos artistas ya nombrados, cuya influencia es relevante; pero también se observa la huella de las obras de algunos pintores barrocos españoles, sobre todo andaluces, entre los que se encuentran $\operatorname{artistas}^{15} \tan$ notables como Antonio del Castillo, José de Cieza, Alonso Cano, Ignacio de Iriarte y el afamado Esteban Murillo, al que ya nos hemos referido. Todos ellos trataron el paisaje con la presencia de ruinas clásicas cubiertas de vegetación, como fueron generalmente representadas desde el siglo XVII hasta el Romanticismo. Abundan en estas obras 
bucólicas los paisajes surcados por ríos o arroyos, algún puente y un conjunto de ruinas clásicas, formado por columnas --casi siempre con su entablamento-- restos de arcos, pedazos de murallas, esculturas mutiladas, así como fragmentos de piedras diseminadas por el suelo. Se percibe, además, una abundante vegetación, invasiva en el caso de las ruinas, y delante de ellas algún pastor o pastores con ovejas que pastan. A veces aparece la entrada a un pueblo o núcleo urbano, al que se accede a través de un pórtico u otra forma de entrada, casi siempre fruto de la imaginación de estos pintores. Las pinturas de paisajes pastoriles unen ciertos elementos comunes en "un todo armonioso" que evoca una especie de paraíso terrenal. Bécquer resucita estos espacios vegetales, heredados del Renacimiento, en los cuales transcurre la trama de algunos de sus relatos o de los que se vale para explicar el sutil mundo interior del poeta, mediante descripciones mucho más pictóricas que reales.

Conociendo sus estrategias intermediales, debemos plantearnos la abundancia de estos espacios ideales en los que Bécquer enmarca algunos de sus textos. La aparición de estos espacios domesticados --en el caso de Bécquer, por la mano del artista-- se debe al interés de éste por crear, primeramente, un espacio utópico e irreal, como un marco ajeno a las exigencias del tiempo; aunque también debemos relacionarlos con la poética del silencio, con los que comparte la concisión, la brevedad y el deseo de perfección en un espacio limitado. Pero hay otras connotaciones que debemos tener en cuenta: El locus amoenus por su matiz de jardín cerrado, fuera del tiempo, también nos remite a la relación vida-muerte, a la idea de paraíso perdido, de soledad, de nostalgia, entre otras ideas, a la luz de algunas reflexiones teóricas que 
se avienen con la filosofía de Bécquer. Para Roland Barthes, "la polaridad el jardínfuera del jardín representa la muerte y la vida, lo frío y lo caliente, el exterior y el interior (13)". Habría que destacar, además, que la polaridad exterior-interior puede representar el mundo cerrado del arte en contraste con el mundo real, expuesto al irreversible paso del tiempo.

Existen, desde luego, otras variantes del modelo pastoril expuesto, en los que podría aparecer una mayor proporción de elementos arquitectónicos, o incluso otros distintos (escaleras, bóvedas, entre otros), pero es evidente el grado de influencia del paisaje pastoril en las descripciones referidas en esta leyenda. Por otro lado, la convergencia de la ruina clásica o la cristiana de tradición medieval, los rebaños de ovejas, la luz crepuscular, la luna, la noche, lo inerte de la pieza arqueológica, entre otros conceptos e ideas, crearán una compleja trama de la sensibilidad romántica en el cuadro becqueriano, heredada, en parte, de Chateaubriand, así como de sus propias investigaciones histórico-artísticas.

En “Creed en Dios ${ }^{16}$ (Cántiga [sic] provenzal)", Bécquer inicia su relato, precisamente, con un paisaje idílico, eco de una oda virgiliana o del propio Garcilaso de la Vega, un locus amoenus que adjetiva a un espacio hermoso, idílico, fértil y seguro:

Pastores que seguís con lento paso vuestras blancas ovejas, que pacen derramadas por las colinas y las llanuras; si al conducirlas al borde del trasparente riachuelo que corre, forcejea y salta por entre los peñascos del valle de Montagut ${ }^{17}$, en el rigor del verano y en una siesta de fuego, habéis encontrado la sombra y el reposo al pie de las 
derruidas arcadas del monasterio, cuyos musgosos pilares besan las ondas, oídme. (248-9)

Es evidente la correlación de estos elementos con los de los paisajes virgilianos de los pintores barrocos andaluces. Quizás con la sola excepción del puente, posiblemente reemplazado por piedras sobre el riachuelo, la única variante que se percibe, pero que también aparece en algunos de los paisajes de esos artistas, es la presencia del elemento montañoso --que es también una figura importante del paisaje barroco y romántico por la sublimidad en su representación--, aunque, curiosamente, se lo consideró durante siglos un lugar inseguro y pavoroso, mutando este símbolo por el de "paisaje sublime", durante el Romanticismo. En los párrafos subsiguientes, Bécquer refiere otras escenas del "sombrío monasterio... y de su claustro mudo y desierto..., de las abandonadas tumbas, a cuyos bordes crecen las margaritas más nobles y los jacintos más azules" (249). De nuevo el color blanco de la margarita y el azul de los jacintos irrumpen en el paisaje becqueriano; colores que constituyen casi una presencia obligada en el paisaje becqueriano. Este "bicromatismo" romántico-simbólico, tal y como lo llamaré en este análisis, es heredero del Romanticismo.

El blanco es, según el simbolismo romántico, el color más perfecto. No hay ningún "concepto blanco" de significado negativo. Es el color del comienzo, significa paz o rendición. Es también el color del bien y la honradez. Lo blanco por otro lado simboliza la pureza absoluta. Bécquer lo utiliza para dar el tono deseado al cuadro, combinándolo o no con el azul. En cuanto al azul, Víctor Hugo, uno de los mayores exponentes del Romanticismo, afirmó que L'art c'est l'azur (El arte es el azul). Para 
los románticos, el azul representaba la inmensidad del mar, del cielo y de la atmósfera, lo inabarcable desde el punto de vista humano. También tiene un simbolismo de melancolía y de calma y suele asociarse con la serenidad y el sosiego. Hay críticos que afirman, por el contrario, que viene del Romanticismo alemán, del concepto relacionado con "Die blaue Blume" (La flor azul), por cuanto era una flor -una rosa-- imposible de lograr, símbolo de algo anhelado, pero también inalcanzable. Un ideal, en definitiva. Para Bécquer fueron colores apropiados para expresar ciertas ideas y sentimientos.

Toda la leyenda gira en torno al señor Teobaldo de Montagut, barón de Fortcastell, señor feudal de la región. En cuanto a la naturaleza histórica de esta leyenda, hay varias fuentes que documentan la existencia del señorío de Montagut, pero no hay pruebas que confirmen la de la baronía de Fortcastell. Parece ser, además, que el monasterio aludido por Bécquer, "no es otro que el monasterio cisterciense de Santes Creus" (248), de acuerdo con Pascual Izquierdo. Por lo tanto, estamos, por un lado, ante "recreaciones arqueológicas puras", pero por otro, Bécquer se vale de "reinterpretaciones arqueológicas"; lo que avala tanto el valor histórico de la tradición, aunque sea de forma limitada, como el valor artísticocreativo, resultado de las "reinterpretaciones". En la propia leyenda, Bécquer hace un aparte para dirigirse a los que "escuchan" su relato, y nos dice: "si os maravilla lo que os cuento, no creáis que es una fábula tejida a mi antojo para sorprender vuestra incredulidad. De boca en boca ha llegado hasta mí esta tradición... Creed, pues, lo que os he dicho, y creed lo que aún me resta por decir, que es tan cierto como lo anterior, pero más maravilloso" (255). 
Es decir, el propio Bécquer quiere justificar la "veracidad" de la tradición, pero lo hace apoyado en el argumento de que la tradición popular, desde su visión artística, es un equivalente superior a la historia, pues el elemento mágico, "maravilloso", como afirma, es sólo posible al margen de ésta; con lo cual, parece reafirmar, una vez más, que sólo el arte es capaz de recrear el ideal.

Siguiendo esta línea de recreación del ideal, el locus amoenus, un tópico en continua evolución, sobre todo en pintura, puede presentar marcos naturales utópicos (el paisaje idealizado), ambientaciones idílicas (paisajes heroicos o clásicos) para determinados ambientes, o imágenes en las que la mano del hombre se hace evidente (paisaje domado o colonizado). Bécquer apela a una combinación de todos estos elementos para ofrecer al lector-espectador un paisaje que persigue determinados propósitos. La pincelada, el color, el dibujo, las formas, la luz, la composición, la escala, entre otros elementos de este paisaje, pasan a convertirse en recursos expresivos, cuyo activo papel condiciona la lectura-visualización por parte del lector.

De acuerdo con la teoría de las constantes históricas, el Romanticismo vendría a ser una suerte de continuación del período barroco, tras el período neoclásico. Pero aunque esto no es literalmente así, no hay duda de que pueden establecerse --con la moderación requerida y las limitaciones lógicas-- ciertos rasgos comunes en los paisajes barrocos y románticos. La presencia de bosques salvajes, de una vegetación indomeñable, ante los cuales el hombre parece desaparecer o empequeñecerse ante la magnitud del paisaje, podrían ser escenarios comunes a ambas estéticas. La recurrencia de Bécquer a artistas barrocos como Lorrain, Poussin, Murillo, o Rembrandt, 
entre otros, no hace más que confirmar esta corriente artística. Hay, pues, una cierta corriente que hermana ambas vertientes artísticas. Sin embargo, su visión de las ruinas es distinta, según se las contemple desde una u otra perspectiva. Baquero Goyanes se ha expresado así:

En [el Barroco] las ruinas representan el triunfo de la naturaleza sobre la obra del hombre. Si éste, en el período neoclásico, pudo entrar con sus tijeras y sus medidas en los jardines, sometiéndolos a esquema y a racional estructura, ahora la naturaleza toma su revancha, y en forma de yedra, jaramago y lagartos va royendo los edificios del hombre, hasta irlos reduciendo a unos esqueletos asfixiados por el follaje, oprimidos por la vegetación triunfante. Por el contrario, las ruinas barrocas significan no tanto el triunfo de la naturaleza sobre la obra del hombre, como el triunfo del tiempo. ("Dos ensayos" 1)

Aunque ambas ideas, naturaleza y tiempo, están estrechamente ligadas, lo que prevalece en Bécquer --y en el hombre romántico, en general-- es la idea de la naturaleza como expresión de vida. Por ello, las ruinas se presentan en medio de una vegetación invasiva que va recuperando su espacio natural, el que el hombre le robó. Así, aunque la ruina becqueriana nos hable de la muerte (El memento mori) o de la caducidad casi barroca de las cosas, la imagen que transmite Bécquer es de vida, pues en las ruinas late ésta, ya sea a través de la vegetación que va cubriendo las piedras inertes o de los animales que viven entre ellas. Por eso, la ruina en el paisaje becqueriano es un elemento compositivo de gran importancia, porque representa el triunfo de la naturaleza, a un nivel poético si se quiere, sobre la obra 
del hombre. De esta manera, entre edificios y ruinas, Bécquer inicia "El Miserere (Leyenda religiosa)"18 con la descripción de un paisaje, donde confluyen algunas edificaciones: la abadía de Fitero ${ }^{19}$, una construcción que Bécquer había estudiado para la Historia de los templos de España; un castillo que había sido convertido en monasterio, así como las ruinas de la iglesia que se había construido en éste. No hay duda, al margen de la inclusión en esta leyenda de la abadía de Fitero, de que la documentación acumulada para la elaboración de la Historia está presente en esta leyenda, que el propio autor subtitula como "Leyenda religiosa", quizás para destacar su origen.

El cuadro que nos presenta Bécquer del monasterio tiene como antecedente una descripción atmosférica: “[R]emontando la corriente del riachuelo que le indicó el rabadán de la historia, llegó al punto en que se levantan, negras e imponentes, las ruinas del monasterio... La lluvia había cesado; las nubes flotaban en oscuras bandas, por entre cuyos jirones se deslizaba a veces un furtivo rayo de luz pálida y dudosa" (268).

La presencia del riachuelo, un eco del paisaje barroco andaluz de influencia pastoril, así como la débil luz del crepúsculo loreniano, tras la tormenta, se dibujan como el marco ideal para "las negras ruinas" del monasterio, que parecen haberse inspirado en el cuadro de Caspar. D. Friedrich, “Abadía bajo los robles" (1809-10). Bécquer nos pinta el estado actual de esas ruinas, añadiendo nuevos elementos compositivos a la pintura esbozada hasta ir completando su idea del paisaje como ambientación de la pintura deseada; pero, además, se vale de eficaces percepciones acústicas para completar el cuadro: 
Las gotas de agua que se filtraban por entre las grietas de los rotos arcos y caían sobre las losas con un rumor acompasado...; los gritos del búho, que graznaba refugiado bajo el nimbo de piedra de una imagen de pie, aún en el hueco de un muro; el ruido de los reptiles, que, despiertos de su letargo por la tempestad, sacaban sus deformes cabezas de los agujeros donde duermen o se arrastran por entre los jaramagos y los zarzales que crecían al pie del altar, entre las junturas de las lápidas sepulcrales que formaban el pavimento de la iglesia... En el derruido templo no había campana, ni reloj, ni torre ya siquiera. (269)

La precisión en los detalles descriptivos contribuye a crear, también en lo pictórico, un interesante y vívido cuadro del ruinoso conjunto. El ritmo acompasado con el que Bécquer parece ir enfocando, uno a uno, los distintos elementos arquitectónicos del monasterio --como si de la presencia de una secuencia de cuadros se tratara-- nos hace ir imaginándolos, recreándolos en su forma y color, a medida que avanza la descripción ecfrástica de las ruinas. Ante esta "deconstrucción" del templo a causa del tiempo transcurrido y el abandono en que había quedado, Bécquer recurre a un giro inesperado, pues cuando comienzan a escucharse las primeras notas del Miserere mei, Deus, el monasterio inicia su repentina y mágica "reconstrucción", dando marcha atrás en el tiempo hasta alcanzar su estado original:

[L]os doseles de granito que cobijaban las esculturas, las gradas de mármol de los altares, los sillares de las ojivas, los calados antepechos 
del coro, los festones de tréboles de las cornisas, los negros machones de los muros, el pavimento, las bóvedas, la iglesia entera comenzó a iluminarse espontáneamente... Todo pareció animarse... Las piedras se reunieron a las piedras; el ara, cuyos rotos fragmentos se veían antes esparcidos sin orden, se levantó intacta, como si acabase de dar en ella su último golpe de cincel el artífice, y a la par del arase levantaron las derribadas capillas, los rotos capiteles y las destrozadas e inmensas series de $\operatorname{arcos}$ que, cruzándose y enlazándose caprichosamente entre sí, formaron con sus columnas un laberinto de pórfido. (269-70)

Llaman la atención, sin duda, los numerosos términos arquitectónicos que Bécquer llega a emplear con gran acierto en esta écfrasis, los cuales se derivan, sin duda, de su preparación artística para la Historia de los templos de España; o quizás adquiridos durante su formación como pintor en los talleres sevillanos. Pero resulta todavía más sorprendente este recurso de "reconstruir" el templo a partir de las ruinas --como sólo podría hacerlo un artista-- en una labor de "restauración" pictórica que le era tan cara a Bécquer, por cuanto uno de sus grandes afanes era la recuperación de monumentos y obras artísticas en peligro de desaparecer.

Recordemos, por otro lado, sus labores de restauración en el alcázar de Sevilla, junto a su hermano Valeriano, y bajo la guía de Joaquín Domínguez Bécquer. Todo ello pudo haberle influido positivamente, pues lo consideramos un recurso novedoso con el que nos hace "ver" el templo en su estado original a la par que en su estado ruinoso; algo que lo sitúa dentro de lo maravilloso, desde el punto de vista 
temporal. Por otra parte, la plasticidad de estos efectos de deconstrucción y construcción convierten a la prosa becqueriana en algo más que en una prosa pictórica o prosa plástica en su sentido más amplio, por cuanto esta labor debe ser vista, fundamentalmente, como composición pictórica, como artificio del pincel y como expresión de un paisaje manipulado por un pintor, como si de una pintura se tratara.

Dos grandes escenas descriptivas de una gran calidad plástica, concurren en "El Cristo de la calavera ${ }^{20}$ (Leyenda toledana)". En éstas, Bécquer despliega, una vez más, su habilidad para el dibujo y la aplicación acertada del color, dentro de una rigurosa composición de escenarios, en los que concurre, además, una singular pintura de vestuarios, muy del gusto prerrafaelista. En todo ello, Bécquer no sólo manifiesta poseer el ojo y la mano de un artista experimentado, sino que, también, se pone de relieve su habilidad de narrador de efectos sonoros y percepciones acústicas.

El primer cuadro que nos ofrece Bécquer tiene una fuerte impronta costumbrista, que acentúan, por otra parte, los expresivos valores plásticos; y todo en una composición abigarrada, pero separada por niveles de distancia con relación al espectador ("éstos, aquéllos, los otros, los de más allá"), en la que no se excluyen expresiones sonoras (gritos, blasfemias, juegos, repeticiones en coro, música, risas estrepitosas, ruidos atronadores) que desbordan nuestra capacidad sensorial. Cabe destacar, por otra parte, el tratamiento realista que le otorga Bécquer al cuadro costumbrista. Se trata de la noche del sarao en el histórico Alcázar de los Reyes, en la ciudad de Toledo: 
En los anchurosos patios, alrededor de inmensas hogueras y diseminados sin orden ni concierto, se veía una abigarrada multitud de pajes, soldados, ballesteros y gente menuda, que, éstos aderezando sus corceles y sus armas y disponiéndolos para el combate; aquéllos saludando con gritos o blasfemias las inesperadas vueltas de la fortuna, personificada en los dados del cubilete; los otros repitiendo en coro el refrán de un romance de guerra que entonaba un juglar, acompañado de una guzla; los de más allá comprando a un romero conchas, cruces y cintas tocadas en el sepulcro de Santiago, o riendo con locas carcajadas de los chistes de un bufón... formaban un infernal y atronador conjunto, imposible de pintar con palabras. (276)

Me quedo, por ahora, con la última expresión: "imposible de pintar con palabras". De nuevo, el artista-narrador apela al recurso de declarar su incapacidad para describir una escena, cuando, de hecho, ha terminado pintándola; esto es, “describiéndola plásticamente". Aquí, la conjunción palabra-imagen se impone, una vez más, como la solución "posible" para hacernos "ver", que es su prioridad y propósito estético. No hay duda de que Bécquer desea enfatizar la presencia del cuadro, del objeto visual, y nada mejor para llamar nuestra atención que negando en principio la capacidad del "objeto textual", pero "mostrándonos", al mismo tiempo, la escena pintada, que viene a completar el sentido y, de cierta forma, activar la recepción del texto. Además, para enlazar esta escena popular que se desarrolla en el exterior del alcázar, y que acabamos de "ver", Bécquer insiste sobre la condición de cuadro, es decir, de pintura, del segundo "sarao": "Éste, que tenía lugar en los 
salones que formaban el segundo cuerpo del alcázar, ofrecía, a su vez, un cuadro, si no tan fantástico y caprichoso [se refiere al anterior cuadro], más deslumbrador y magnífico" (277). La comparación de Bécquer, a primera vista, no parece arrojar una marcada predilección por uno u otro cuadro, pero al rato podemos deducir -por el tono general que le imprime-- que se decanta por el segundo. Si el primero, el del pueblo celebrando el sarao en el patio del alcázar, es "fantástico y caprichoso", el cuadro interior, donde se concentran los reyes y los nobles, se percibe más "deslumbrador y magnífico". En clave ideológica, este cuadro se corresponde mucho más con el tradicionalismo becqueriano.

No inferimos muy claramente lo que quiso decirnos Bécquer con el calificativo de "caprichoso" para definir el sarao exterior, a menos que lo veamos como un espectáculo espontáneo y no sujeto a reglas; todo lo contrario del mundo social estratificado de la corte, que se movía en el interior del alcázar; un mundo sujeto a férreas leyes sociales, quizás mucho más terribles, como parece indicar el desenlace de la leyenda. Es probable que Bécquer, en su afán de componer en planos --tal y como se deriva de sus estudios sobre las composiciones de Poussin y Lorrain- haya hecho una división de los "saraos" del alcázar en dos niveles pictóricos diferenciados (exterior-inferior e interior-superior), como forma de mostrar lo que ocurre en cuadros distintos, aunque ambos concurran en un mismo espacio arquitectónico, pero no en el mismo espacio visual21. Veamos, pues, la pintura del interior realizada por Bécquer:

Por las extensas galerías que se prolongaban a lo lejos, formando un intrincado laberinto de pilastras esbeltas y ojivas caladas y ligeras 
como el encaje; por los espaciosos salones vestidos de tapices, donde la seda y el oro habían representado con mil colores diversos escenas de amor, de caza y de guerra, y adornados con trofeos de armas y escudos, sobre los cuales vertían un mar de chispeante luz un sinnúmero de lámparas y candelabros de bronce, plata y oro, colgadas aquéllas de las altísimas bóvedas y enclavados éstos en los gruesos sillares de los muros. (277)

Esta primera parte del segundo cuadro se centra en los espacios arquitectónicos del alcázar y su decoración. Los detalles, adjetivos y comparaciones de que se vale Bécquer, nos remiten a una arquitectura de cierta magnificencia, a tenor de la clase social que se mueve en ella; porque hay, indiscutiblemente, una sintonía plástica total entre el continente y el contenido. Las largas galerías de indiscutible estilo gótico, como avalan los arcos ojivales; los ricos tapices, los trofeos y escudos, y los no menos suntuosos candelabros y lámparas de nobles metales, evidencian un mundo, sí, "deslumbrador"; de eso no hay duda, y "magnífico", en el sentido de suntuoso y espectacular.

En la segunda parte de este cuadro, además, Bécquer describe la suntuosidad de los trajes, tanto de las damas como de "los galanes" --los caballeros de la corte-allí presentes, así como de las joyas que llevan, aunque lo descrito hace pensar que los referentes utilizados por Bécquer, más que medievales, parecen provenir de la pintura prerrafaelista inglesa o de los llamados "nazarenos" alemanes. El cuadro interior comparte similitudes con la obra de John Everett Millais, "Isabella" (180910), si no en el tema del cuadro o la composición del mismo, sí en el tratamiento de 
la vestimenta de los personajes, en el que Bécquer se permite algunas licencias neogóticas, propias del estilo prerrafaelista, en cuanto al dibujo y colorido.

La riqueza cromática está expresada indirectamente, a través de los metales (el oro, la plata, el bronce), combinaciones de plata y oro como la filigrana, o bien a través de otros elementos de valía (los rubíes, las perlas, y el marfil); lo cual nos lleva a imaginarlos y visualizarlos en función de sus referentes textuales más genéricos. En cuanto a la mención del color, como tal, salvo "los blancos encajes" -de nuevo, el blanco romántico-- y los "mil colores" de los tapices, no hay una mención directa a los colores del cuadro, aunque los "mil colores" pueden aludir a todos y a ninguno, al mismo tiempo. La riqueza de las telas y las pieles no aparecen calificados por su color de forma directa: brocados (en oro y plata, generalmente), sedas, terciopelos, tafiletes, no reflejan los colores, pero "imaginamos" la pluralidad cromática de los mismos, siguiendo un modelo ya estrenado por Bécquer en anteriores leyendas. Creemos --y queremos insistir en ello-- que la recepción activa que demanda Bécquer del lector-espectador, lleva implícita, además, la existencia en el lector-espectador de cierta sensibilidad artística, y hasta de cierto conocimiento de los movimientos artísticos, pues sin éstos sería dudosa e incompleta la recepción que espera de ese lector activo.

No escapa en "El Cristo de la calavera" una posible lectura ideológica, pues la propia composición de Bécquer para describir en dos planos distintos el sarao exterior del pueblo y el baile interior de la nobleza, parece prefijar en planos estéticos --y hasta sociales-- dos niveles distintos, cuya actuación diferenciadora queda marcada por los prejuicios de clase que afloran en la descripción de ambos 
grupos. Desde su proyecto de la Historia de los templos de España, Bécquer, como ya lo había hecho Chateaubriand en su obra Génie du Christianisme --un referente obligado al analizar la obra de Bécquer-- se decanta por aunar a una defensa de las viejas instituciones, una voluntad creciente de renovación profunda, lo que constituye una de las características iniciales típicas del historicismo europeo romántico.

Siguiendo su estilo de componer en planos pareados, Bécquer estructura "La promesa $^{22}$ (Leyenda castellana)", esencialmente, sobre dos cuadros. En el primero, Bécquer retrata la tristeza del personaje, estableciendo un paralelo entre el estado de ánimo de éste y la naturaleza descrita, que lo refleja dentro de un esquema de caracterización, que es fundamentalmente romántico, aunque con antecedentes renacentistas --específicamente de Garcilaso de La Vega-- por las connotaciones emotivas y pasionales que Bécquer proyecta en el paisaje crepuscular, el más apropiado para expresar esos sentimientos:

Y todo callaba alrededor y parecía respetar su pena. Los rumores del campo se apagaban; el viento de la tarde dormía y las sombras comenzaban a envolver los espesos árboles del soto. Así transcurrieron algunos minutos, durante los cuales se acabó de borrar el rastro de luz que el sol había dejado al morir en el horizonte; la luna comenzó a dibujarse vagamente sobre el fondo violado del cielo del crepúsculo, y una tras otras fueron apareciendo las estrellas. (314)

Las reminiscencias pictóricas se deben, sobre todo, a Lorrain, pero no escapan otras asociaciones con la pintura romántica alemana y española. Entre la 
primera, desde luego, se encuentra Caspar D. Friedrich, en obras como "Atardecer" (1830) o "Soñador" (1835), entre otras muchas obras de este artista con el tema del crepúsculo. Y entre las españolas, a Genaro Pérez Villaamil, en obras como “Garganta de las Alpujarras" (1848); a Manuel Barrón y Carrillo, en una serie de obras de atardeceres en Sevilla, pintados entre 1840 y 1851; y a la propia familia de Bécquer, esto es, su padre, primo y hermano, exponentes todos del paisaje andaluz a distintas horas del día. No descartamos otros referentes, habida cuenta de las periódicas visitas de Bécquer al Museo del Prado, poseedor de un cuantioso inventario de obras con este tema. Cualquiera que haya sido la influencia, cabe destacar que la solución de este primer cuadro, como escenario de la acción, es indiscutiblemente de índole pictórica.

El segundo cuadro se estructura alrededor del amanecer y la aparición de los campesinos a las afueras de la fortaleza para presenciar la salida del séquito del Conde de Gómara: “Unos sentados en los bordes de los fosos, otros subidos en las copas de los árboles, éstos vagando por las llanuras, aquéllos coronando las cumbres de las colinas, los de más allá formando un cordón a lo largo de la calzada" (316). De nuevo Bécquer organiza los elementos del cuadro, colocándolos en distintos planos compositivos, y organizados en grupos aislados, como exponente del espacio que esboza --reflejo, por otra parte, de la desorganización popular-- lo que se define por los términos empleados ("unos, otros, éstos, aquéllos, los de más allá") con relación al primer plano, reservado para las ordenadas huestes del conde de Gómara. De esta forma, también se hace evidente la separación de clases en la composición del cuadro, pues se reserva el primer plano para el orden. Según 
avanzamos en la lectura, una sucesión de cuadros de paisajes, el primero, de claro estilo neomudéjar y, por lo tanto, historicista, ponen de manifiesto las habilidades de Bécquer como pintor paisajista al describir este expresivo cuadro inundado de luz murillesca, que intuimos dorada por el símil con las llamas de fuego:

Enfrente del real [de los cristianos], y destacándose sobre el luminoso horizonte, se alzaban los muros de Sevilla, flanqueados de torres, almenadas y fuertes. Por cima [sic] de la corona de almenas rebosaba la verdura de los mil jardines de la morisca ciudad, y entre las oscuras manchas del follaje lucían los miradores blancos como la nieve, los minaretes de las mezquitas y la gigantesca atalaya, sobre cuyo aéreo petril lanzaban chispas de luz, heridas por el sol, las cuatro grandes bolas de oro, que desde el campo de los cristianos parecían cuatro llamas. (320)

El hecho de que Bécquer fuera sevillano, por un lado, y su exposición directa a los ambientes moriscos andaluces, por demás plasmados por los artistas de su propia familia y del círculo de pintores que rodeaban a su padre --aspecto que ya hemos tratado extensamente por su importancia para este trabajo-- parecen, por otro lado, haber influido en la visión pictórica que nos presenta en este cuadro. Es obvio, además, que Bécquer dominaba el vocabulario arquitectónico árabe, la importancia del jardín y del color, sobre todo el blanco, y la función y protagonismo de la luz en los escenarios moriscos, elementos todos que parece condensar en la anterior descripción. El color, sin embargo, no es abundante, pero lo dosifica en certeras pinceladas impresionistas: el blanco de las torres, el dorado de las bolas, el 
verde de la espesa vegetación. El hecho de utilizar "manchas de follaje", un término esencialmente pictórico, hace pensar en un tratamiento suelto de la pincelada, muy dentro del estilo de algunos pintores sevillanos del entorno familiar, incluyendo a su padre. Con estos limitados recursos cromáticos, Bécquer nos muestra un "colorido" paisaje, que nos impresiona por los contrastes de que se vale el artista y la presencia activa y determinante de la luz.

En un segundo cuadro, cargado de elementos costumbristas y percepciones auditivas, Bécquer concluye la descripción ecfrástica con su consabido sello sobre la imposibilidad de "pintar con palabras" el cuadro a la vista. En esta recreación plástica, los distintos grupos de las huestes condales se organizan en puntos distantes, como en esas composiciones tan propias de la pintura histórica del siglo XIX: “Aquí descansaban algunos señores de las fatigas del combate...; allí algunos peones aprovechaban un momento de ocio para aderezar sus armas...; más allá cubrían de saetas un blanco los más expertos ballesteros" (321). A cada uno de estos tres grupos, diseminados en la composición del lienzo, Bécquer acompaña alguna actividad que le da movilidad y vida a los grupos. A los señores, "sentados a la puerta de sus tiendas y jugando a las tablas" (321), les acompañan un grupo de pajes que "escanciaban el vino en copas de metal" (321). Los peones se hallan entregados a la faena de "componer las armas rotas en la última refriega" (321). El tercer grupo, el de los ballesteros, les acompañan "una multitud, pasmada de su destreza" (321). Bécquer elabora una serie de écfrasis sonoras para acompañar la escena, pues en estos cuadros es tan importante ver como escuchar. Veamos esta descripción de gran valor acústico: 
[E]l rumor de los atambores [sic], el clamor de las trompetas, las voces de los mercaderes ambulantes, el golpear del hierro contra el hierro, los cánticos de los juglares... y los gritos de los farautes que publicaban las ordenanzas de los maestres del campo, llenando los aires de mil y mil ruidos dispares, prestaban a aquel cuadro de costumbres...una vida y una animación imposibles de pintar con palabras. (321)

El equilibrio compositivo, no hay duda, es obra de un pintor experimentado. Algunos críticos han mencionado, en más de una ocasión, las posibles influencias artísticas de su hermano (Rica Brown, Benítez, entre otros), algo que, conociendo la compenetración de ambos y la forma en que trabajaban en algunas ocasiones; esto es, narrar a partir del cuadro, o pintar a partir de la narración --lo que está debidamente documentado y a lo que nos hemos referido en este trabajo-- no atenta, en ningún sentido, contra la capacidad creativa de Bécquer; pienso, más bien, que es todo lo contrario, la exalta.

En "La corza blanca"23, Bécquer vuelve a situarnos ante un paisaje bucólico de singular belleza plástica. La idea del campo como lugar agradable de retiro o reposo es muy antigua y de gran importancia para la pintura paisajística, como ya hemos abordado. Bécquer compone este paisaje a partir de ciertos elementos "naturales", aunque sin pretender reflejar la realidad visualmente observada, sino el equivalente visual de la llamada poesía pastoril, tal y como aparece reflejada en escenarios virgilianos de anteriores leyendas y muy particularmente en ésta: Durante una cacería, don Dionís --uno de los personajes de esta tradición-- y sus 
acompañantes, sintiendo la necesidad de descansar, hallaron refugio en "en el monte de su feudo..., en una cañada por donde corría un riachuelo saltando de roca en roca con un ruido manso y agradable" (328). De esta manera, "recostado sobre la menuda grana, a la sombra de una chopera, departiendo amigablemente con sus monteros... empezaron a saltar por entre las apiñadas matas de cantueso y tomillo y a descender a la orilla opuesta del riachuelo, hasta unos cien corderos blancos como la nieve, detrás de los cuales..., apareció el zagal que los conducía" (328). Los elementos necesarios del paisaje pastoril, aunque en pequeñas pinceladas, contribuyen a esbozar este paisaje y darle cierto sentido de escenario "terminado": la cañada, la menuda grana, el monte que ocultaba la sorpresiva aparición del rebaño, el riachuelo con su "mansa y agradable agua", los corderos blancos como la nieve --un símil repetitivo en Bécquer-- y el joven pastor, un personaje hasta ahora ausente de los cuadros legendarios, pero que he mencionado antes como uno de los elementos integradores del paisaje pastoril barroco (Me refiero al paisaje "clásico"). No podemos afirmar que se trate de un inventario impresionante, pero sí del número de elementos mínimos que se requieren para conformar el cuadro ecfrástico de un paisaje pastoril, y como anticipación pictórica de la narración fantástica.

Le sigue en el orden plástico un cuadro de singular belleza, representado por los desnudos de las mujeres bañándose en el río, precedido por una de las escenas atmosféricas que Bécquer elabora como recurso expresivo con que dotar al cuadro de una determinada ambientación. La ejecución de efectos atmosféricos (La llamada descripción de las atmósferas), de la que Turner es uno de sus grandes exponentes, 
siempre se ha considerado uno de los grandes retos de los pintores de paisaje. Tales efectos constituían una demostración de la habilidad del pintor para observar y plasmar la naturaleza; una de las grandes aspiraciones, por demás, de los románticos. Abocetar en exteriores formaba parte de la práctica habitual de los artistas de paisaje, ya que todavía no se había extendido la práctica de pintar al aire libre. Bécquer inició la práctica de realizar apuntes o bocetos desde mucho antes, lo que hacía a veces en compañía de Valeriano, sobre todo en los alrededores del Moncayo --escenario de esta leyenda-- como prueban sus propios dibujos o los de su hermano, que solían dibujarse uno al otro. Es muy probable, además, que en las clases de pintura, en los talleres de Cabral Bejarano y Joaquín Domínguez Bécquer, nuestro autor haya sido adiestrado en el dibujo o la pintura a diferentes horas del día, como ya se recomendaba entonces, puesto que Bécquer demuestra una especial habilidad artística en las descripciones atmosféricas, sobre todo las relacionadas con la luz del sol y de la luna, como hace en el siguiente fragmento: "La luna, que había ido remontándose con lentitud por el ancho horizonte, estaba inmóvil y como suspendida en la mitad del cielo; su dulce claridad inundaba el soto, abrillantaba la intranquila superficie del río y hacía ver los objetos como a través de una gasa azul" (342-3). Observemos que con una asombrosa economía de líneas, Bécquer ha definido en términos artísticos un interesante paisaje lunar, en donde podemos percibir hasta el movido reflejo de la luz sobre el río. La gasa azul --un recurso loreniano que ya hemos analizado-- crea una necesaria atmósfera envolvente y, hasta cierto punto, misteriosa, que nos prepara sicológicamente para la escena del baño en el río. 
Ante la pintura de las bañistas, Bécquer nos dibuja, todavía como antecedente del cuadro principal, una escena, que por su naturaleza pictórica, resulta importante destacar: “En esos ligeros y cortados sueños de la mañana, ricos en imágenes risueñas y voluptuosas, sueños diáfanos y celestes como la luz que entonces comienza a transparentarse a través de las blancas cortinas del lecho, no ha habido nunca imaginación de veinte años que bosquejase con los colores de la fantasía una escena semejante" (343).

La impresión de Garcés frente al cuadro de las bañistas, contiene algunos elementos que son relevantes. Primeramente, la imaginación del personaje es insuficiente, según declara, para haber "bosquejado" --esto es, pintado-- una escena como la que tiene a la vista. Con ello, Bécquer utiliza una variante de su conocido recurso sobre la imposibilidad de "imaginar" --o pintar con palabras-- determinada escena. Por lo tanto, ni siquiera la claridad y nitidez de los sueños de la mañana, que utiliza como imagen, parecen haber contribuido a posibilitar ese bosquejo. Y sin embargo, el cuadro está ahí, y es de una plasticidad sorprendente, sólo realizable por un pintor de aguda sensibilidad. La primera escena nos muestra una visión del conjunto:

Despojadas ya de sus túnicas y sus velos de mil colores, que destacaban sobre el fondo suspendidas de los árboles o arrojadas con descuido sobre la alfombra de césped, las muchachas discurrían a su placer por el soto, formando grupos pintorescos, y entraban y salían [sic] en el agua, haciéndola saltar en chispas luminosas sobre las flores de la margen como una menuda lluvia de rocío. (343) 
Bécquer continúa con una práctica, iniciada en los siglos XV y XVI, en cuanto a la exaltación del cuerpo y la representación del desnudo femenino, pensadas para agradar a la vista. Las imágenes de ninfas desnudas en el río --casi un tópico en la historia del arte-- son recurrentes en la pintura europea. Por ejemplo, Diana y sus ninfas sorprendidas por sátiros, una obra importante de Rubens que se encuentra en el Museo del Prado; razón de más para imaginarla como posible fuente de inspiración. Otros referentes pudieron haber sido Baño de ninfas (o Las ninfas de Diana), una obra del siglo XVII de Jan Brueghel; Una mañana. Danza de ninfas, de Gustave Corot; o La vuelta de las hadas al lago, de Teófilo Dióscuro de la Puebla, ya dentro de la pintura española. Destaca aquí, sobre todo, la explosión de color que acompaña a esta descripción de grupo, ya sea mediante los velos y las túnicas --“de mil colores", nos dice-- o las flores de la margen, que aunque no coloreadas, como es parte de su estilo, sí aluden al color de forma "imagística". La escena tiene lugar en el agua o sobre "la alfombra de césped", y tanto una como la otra están rodeadas de espesa vegetación, es decir, de infinitas tonalidades de verde. En las escenas subsiguientes, Bécquer recurre a los enfoques selectivos, como si estuviese filmando esas escenas con una cámara: "Aquí una de ellas, blanca como el vellón de un cordero, sacaba su cabeza rubia, entre las verdes y flotantes hojas de una planta acuática... Otra allá, con el cabello suelto sobre los hombros, mecíase suspendida de la rama de un sauce...y sus pequeños pies color de rosa hacían una raya de plata al pasar rozando la... superficie" (343). Bécquer despliega aquí un abundante uso del color: blanco, amarillo ("rubia"), verdes, rosa y plata. El efecto de tomas de cámara continúa hacia otros dos grupos de ninfas que otorgan a la composición un singular 
movimiento. Bécquer, que sí conoció la fotografía, parece adelantarse a su tiempo con estos cuadros móviles, que más que una secuencia de pinturas estáticas, parecen filmaciones cinematográficas por la manera en que desplaza, digamos, la lente de la cámara.

Desde el punto de vista estructural, la leyenda también se desarrolla en dos planos: un primer plano que representa la realidad, y un segundo plano, que pudiéramos llamar de lo maravilloso; es éste último plano el que Bécquer relaciona con lo artístico, pues lo prosaico lo identifica con la realidad. Por eso estas ensoñaciones o visualizaciones artísticas se mueven en un mundo distinto, en el mundo de la creatividad y del poder de transformación del arte. De acuerdo con Pascual Izquierdo, “Bécquer denuncia en 'La corza blanca' la prepotencia intelectual de la safiedad [sic], brutal y destructora, sobre el fragilísimo cristal del arte" (83).

No podemos soslayar, por su importancia en la determinación de la visión historicista de estas leyendas de trasfondo medieval, que el sentimiento romántico y nacionalista de Bécquer propició la inclusión de una serie de fuentes teóricas asociadas al fenómeno de las recreaciones o revivals medievales, que, recurriendo a su abundante repertorio de grabados originales, reunidos para su proyecto de la Historia, intentaban conservar el recuerdo de la arquitectura del pasado. Para ello, Bécquer se vale de referentes medievales góticos con los que elabora edificios, ruinas y ambientes que intervienen en las composiciones plásticas de los escenarios (re)creados. En este sentido, Bécquer recurre al documento histórico fiable, pero sin infravalorar la tradición con relación a "la historia", lo cual lo coloca en una posición intermedia, a tenor de la multiplicidad de significados de historicismo, pero mucho 
más en línea con la vertiente artística del mismo. Pero lo que debe destacarse en este procedimiento, al menos desde una perspectiva artística, es su intención de provocar un efecto en el lector-espectador. Y este efecto, de acuerdo con Hans Tietze, "es la correlación necesaria de la creación, el vínculo que une al autor individual de la obra de arte con grupos más amplios; hace de una actividad individual una función social y establece primero el carácter histórico de una obra de arte. Consciente o inconscientemente se aspira a provocar un efecto en los espectadores más próximos, o sea, en el público contemporáneo" (Cit. por Hadjinicolaou 29). Por otro lado, Bécquer, como pintor, se inclina más por el papel de las convenciones artísticas que por lo original o lo histórico, en este caso. Por lo tanto, debemos concluir que la "(re)creación histórica" de Bécquer se apoya en la intención de (re)valorizar estilos preteridos de gran significación histórica para España, como lo es su arte gótico, pero recreados para dar color a sus cuadros, crear las necesarias atmósferas y ambientar, no la historia de los hechos --que no es su propósito primario, aunque concurran elementos de la misma--, sino sus relatos legendarios, esto es, sus tradiciones. 


\section{NOTAS AL CAPÍTULO IV}

${ }^{1} \mathrm{El}$ "eclecticismo" es un estilo mixto en las artes, cuyos rasgos son tomados de varias fuentes y estilos, de ahí que nunca fue tomado como un estilo específico. En general, el término describe la combinación en una sola obra de variadas influencias, principalmente de elementos de estilos diferentes históricos en la arquitectura, la pintura, así como en las artes gráficas y decorativas.

${ }^{2}$ El "arqueologismo" se conoce como el intento de reconstruir el arte antiguo con gran fidelidad y rigor.

${ }^{3}$ Dentro de estas leyendas, tenemos "La cruz del diablo", "La ajorca de oro", "El monte de las ánimas", "Los ojos verdes", "El rayo de luna", "Creed en Dios", "El Miserere", "El Cristo de la calavera”, "La promesa" y "La corza blanca”.

4 "La Cruz del diablo" fue publicada por primera vez en La Crónica de ambos mundos, Madrid, 21 y 28 de octubre, y 11 de noviembre de 1860. Es la primera leyenda de Bécquer de asunto español. La denominación "Cruz del diablo", "puente del diablo", etc. es común en Cataluña para llamar a lugares, signos u objetos relacionados con lo sobrenatural-diabólico, de acuerdo con las tradiciones populares.

${ }^{5}$ Bécquer pudo haber leído en crónicas catalanas historias parecidas a las del señor de Segre. Estas historias, entre las que destaca la del "Comte Arnau", con la que presenta algunos rasgos comunes, eran muy populares en la época.

6 "La ajorca de oro" fue publicada originariamente en El Contemporáneo, Madrid, el 7 de noviembre de 1861.

${ }^{7}$ La Virgen del Sagrario, patrona de Toledo, se halla cobijada en la capilla del mismo nombre. De origen y antigüedad muy discutidos, la talla de madera se encuentra cubierta con láminas de plata con la excepción del rostro y las manos. El manto, bordado de perlas, es de una riqueza ornamental excepcional, entre otras muchas joyas que la adornan.

${ }^{8} \mathrm{Al}$ vizconde de Palazuelos (También Conde de Cedillo) se le debe una obra sobre la ciudad: Toledo. Guía Artística-Práctica, 1890, en la que describe, de acuerdo con Pascual Izquierdo y en relación con la Virgen del Sagrario, "una gran ajorca de oro con ricos esmaltes y profusión de piedras preciosas" (189).

9 Bartolomé Esteban Murillo (Sevilla, 1617 - ibíd., 3 de abril de 1682) fue un reconocido pintor español. Del realismo evolucionó hacia fórmulas propias del barroco pleno con una sensibilidad que a veces anticipa el Rococó en algunas de sus más peculiares e imitadas creaciones iconográficas. Personalidad central de la 
escuela sevillana, con un elevado número de discípulos y seguidores que llevaron su influencia hasta bien entrado el siglo XIX.

${ }^{10}$ Bécquer realizó un exhaustivo trabajo de investigación sobre la catedral de Santa María de Toledo, llamada también "Catedral Primada de España", sede de la Archidiócesis de Toledo. Se trata de un edificio de arquitectura gótica, considerado por muchos como la opera magna del estilo gótico en España. Su construcción comenzó en 1226 bajo el reinado de Fernando III el Santo, y las últimas aportaciones góticas se dieron en el siglo XV.

${ }^{11}$ Tenebrismo es el nombre que la historiografía del arte da a un estilo o corriente de la pintura del barroco, correspondiente a su fase inicial, a comienzos del siglo XVII, cuyo principales exponentes son el italiano Caravaggio y José de Ribera (el españoleto, afincado en Nápoles). El tenebrismo se caracteriza por el violento contraste de luces y sombras. Se ha llegado a identificar como una corriente específicamente propia de la escuela española o tenebrismo español.

12 "El monte de las ánimas" fue publicada por primera vez en El Contemporáneo, Madrid, el 7 de diciembre de 1861.

13 "Los ojos verdes" fue publicada originariamente en El Contemporáneo, Madrid, el 15 de diciembre de 1861

14 "El rayo de luna" fue publicada por primera vez en El Contemporáneo, Madrid, en los días 12 y 13 de febrero de 1862 .

${ }^{15}$ Antonio del Castillo (Córdoba, 1616-Ibíd., 1668) fue un pintor barroco español natural de Córdoba, de cuya escuela es el mejor exponente, además de destacar como paisajista y dibujante, José de Cieza (Granada, 1656-Madrid, 1692) fue un pintor barroco español, miembro de una familia de artistas, pues también su padre, Miguel Jerónimo de Cieza, y sus hermanos Vicente y Juan tuvieron oficio de pintor. Desarrolló su actividad entre Granada y Madrid. Puede ser contado entre los más importantes pintores del Siglo de Oro español. Alonso Cano Almansa (Granada, 1601-Ibíd., 1667) fue un pintor, escultor y arquitecto español. Por su contribución en las tres disciplinas y la influencia de su obra en los lugares donde trabajó, se le considera uno de los más importantes artistas del barroco en España, siendo además el iniciador de la Escuela granadina de pintura y escultura. Ignacio de Iriarte (Azcoitia, 1621 - Sevilla, 1670) fue un pintor barrocoespañol establecido en Sevilla, donde se especializó en la pintura de paisajes. Se le puede considerar el primer artista de origen vasco que alcanzó fama más allá de su tierra.

16 "Creed en Dios" fue publicada en El Contemporáneo, Madrid, los días 23, 25 y 27 de febrero de 1862 
${ }^{17}$ En el Valle de Montagut, y en la cumbre de una montaña que domina el llano y el pueblo de igual nombre, todavía permanecen en pie los restos de las murallas y una de las torres.

18 "El Miserere" fue publicada en El Contemporáneo, Madrid, el 17 de abril de 1862.

${ }^{19}$ Monasterio cisterciense de Santa María la Real, fundado por Alfonso VII. Derruido en 1834, su reconstrucción se debió al arzobispo de Toledo, Rodrigo, que era navarro. Es una de las abadías más grandiosas de España.

20 "El Cristo de la calavera" fue publicada en El Contemporáneo, Madrid, el 16 y 17 de julio de 1862.

${ }^{21}$ Las diferencias de carácter social que se derivan de esta composición, quizás coincidentemente, pudieran ampliar la lectura de esta leyenda, conduciéndola por otros derroteros críticos ajenos a nuestro propósito.

22 “La promesa” fue publicada en La América, Madrid, el 12 de febrero de 1863.

23 “La corza blanca fue publicada en La América, Madrid, el 27 de junio de 1863. 


\section{CAPÍTULO V}

\section{EL CUADRO PICTÓRICO COSTUMBRISTA EN “MAESE PÉREZ, EL ORGANISTA”, Y EL ECLECTICISMO EN “EL GNOMO”, “LA CUEVA DE LA MORA”, “EL BESO” Y}

“LA ROSA DE LA PASIÓN”

No podéis figuraos nada semejante a aquella nocturna y fantástica visión que se dibujaba confusamente en la penumbra de la capilla, como esas vírgenes pintadas en los vidrios de colores que habréis visto alguna vez destacarse a lo lejos, blancas y luminosas sobre el oscuro fondo de las catedrales.

\section{"El beso" Gustavo Adolfo Bécquer}

El costumbrismo es, en líneas generales, una corriente o movimiento artístico cuya propuesta se resume en que la obra de arte sea un cuadro de los usos y costumbres de la sociedad. Si se acepta la opinión compartida por muchos críticos, este movimiento surgió de una necesidad plural. Se pretendía, en primer lugar, testimoniar el cambio que se producía en la sociedad decimonónica, pues el presente resultaba, a todas luces, insatisfactorio en más de un sentido: "confuso, contradictorio, dividido entre usos modernos y extranjerizantes que se imponían, y una rancia tradición que desaparecía" (Navas 145). Los escritores más conservadores --entre ellos, Bécquer-- asumieron ante la situación una actitud nostálgica, pero no dejaron de aceptar la modernidad, que les parecía en general positiva, aunque a veces la admitieron con cierta reticencia. El propio interés de Bécquer en el pasado, y en la recreación de monumentos y ruinas de un período de la historia mucho más glorioso, comparte, hasta cierto punto, algunos aspectos 
comunes con la estética costumbrista. Por otro lado, ante la imagen distorsionada de España, que se hacía un lugar en los manuales y guías de viaje, entre otras publicaciones del momento, los costumbristas se sentían comprometidos con la descripción de "la verdad" y con descubrir un país menos deformado por las fantasías románticas. En palabras de José Montesinos, “[l]os viajeros que recorren nuestro país siguen teniendo una visión inexacta, cuando no absurdas, de las cosas españolas; necesario es oponer a sus pinturas descabelladas otras parecidas al objeto y verídicas" (Costumbrismo y novela 46). Para ello, los escritores costumbristas desplegaron ante los lectores un amplio cuadro de tipos y costumbres, que era el resultado de la observación directa y objetiva de la realidad; lo que más tarde sería la base de la gran narrativa realista. Sin embargo, el factor ideológico modificaba esa percepción de la realidad, toda vez que, a la par que observadores, eran "intérpretes", de ahí que más que copias, deba referirme a reflexiones o a interpretaciones de la realidad.

De cierta manera, existen puntos comunes en la forma de describir estas apreciaciones de la realidad, y la de construir --o (re)crear-- los textos ecfrásticos becquerianos. Además, otro aspecto que resulta importante destacar, es el papel de jueces de la sociedad que asumen estos escritores, de censores de determinadas posturas, si se quiere; dicho papel los colocaba al margen de lo expuesto, para, desde ese ángulo, analizar de forma "desapasionada"--de ahí el término "objetivo"-- el cuadro a la vista. Sabemos, por otra parte, que esa ausencia de pasión o imparcialidad en los juicios es totalmente imposible, a la luz de lo explicado con anterioridad, pues la postura ideológica pasa, necesariamente, por cualquier juicio u 
opinión que se emita. De todas formas, el costumbrismo carece del análisis críticosocial del realismo, análisis muy propio del siglo XIX, por las revueltas políticas que se derivaron de los profundos --a veces, radicales-- cambios sociales ocurridos en este siglo.

Bajo el vago nombre de "cuadro de tipos y costumbres", se ocultan matices que es necesario aclarar: Las escenas tienen el propósito de reflejar hechos y aspectos de la vida diaria; los tipos, el de describir personajes. Aparecen también las fisiologías, un término popularizado por Balzac, que consiste en estudiar hechos y tipos, aunque con pretensión analítica. Pero todos estos matices se resumen en algunas características generales que creo importante precisar; y es que estos cuadros se centran "en la pequeña historia, en pequeños sucesos cotidianos, en tipos de poca importancia pública; en fin, en ese entramado activo, pero invisible de la sociedad, que no registran los manuales de historia, pero son el sustrato de ésta" (Navas 146). Los críticos, en general, han definido los elementos formales y discursivos del costumbrismo; en particular, la mediación que se produce entre el mensaje y el receptor a través de la figura de un narrador, a quien une con el lector una cierta complicidad que suele presentarse de varias formas, aunque con un único sistema de coordenadas culturales, espacio-temporales y morales.

Con la llegada del Romanticismo, se vivificó en Europa y, en particular, en España, el interés por las costumbres y tipos populares en la literatura y en la pintura, que aunque fue una constante en toda la península, se dio, de forma preferencial, en Andalucía, por ser esta región la meta soñada de los viajeros del grand tour, como ya hemos explicado en capítulos anteriores. La presencia de 
numerosos extranjeros en estas tierras, sobre todo de ingleses, interesados vivamente en las tópicas escenas andaluzas, hizo que Sevilla se convirtiera en el eje de una importante escuela costumbrista ${ }^{1} \mathrm{y}$ en el centro de convergencia de artistas que se dedicaban a pintar cuadros para estos viajeros. Tenían que ser, eso sí, cuadros de pequeño formato (Las "tablitas" o tableautins) ${ }^{2}$, manejables y fáciles de transportar; debían, por otra parte, representar aquellos temas que interesaban más a los viajeros, las escenas que los distanciaban más de Londres, Glasgow o París: las callejuelas estrechas, los restos de arquitectura medieval --árabe sobre todo--, los trajes típicos, los oficios tradicionales, los vendedores callejeros, los bailes, los toros --y todo lo que girara en torno a las corridas-- y las mujeres, puesto que era un mercado para hombres.

De acuerdo con García Felguera, "[l]a demanda de los forasteros era tan grande que José Domínguez Bécquer no daba abasto y recurría a su primo Joaquín para que le suministrara cuadros que él retocaba, o bocetos que acababa y vendía como propios" (22). Es imposible aceptar que esta actividad haya podido pasar inadvertida para Bécquer y Valeriano, a pesar de su corta edad entonces, ya que alrededor de José Bécquer se había formado, lo que podríamos llamar "una escuela" de seguidores --la escuela costumbrista sevillana--que cultivaron este género de pintura en vida de su maestro, y aún mucho tiempo después de su muerte. Se trata de una pintura amable, fundamentalmente de escenas de la vida cotidiana, aunque también de vistas urbanas y rurales, que incluso sirven de paisaje a escenas costumbristas más íntimas. Los nombres de Joaquín Domínguez Bécquer, Antonio Cabral Bejarano --los dos, maestros de pintura de Bécquer-- y su hermano Valeriano 
Bécquer, el maestro, digamos, informal, alcanzan una importancia relevante en el mundo artístico sevillano.

Cuando Bécquer abandona Sevilla en su marcha a Madrid, en 1854, con él va también esta influencia pictórica del costumbrismo andaluz, que más que apagarse con el tiempo, se verá exaltada --hasta formar parte de su cosmovisión pictóricoliteraria-- y reforzada por el continuado análisis de los temas andaluces y por la presencia de su hermano Valeriano. De acuerdo con Guido Mancini, "Andalucía resta viva en lui accentuandose per la lontananza, non como una generica caratteristica regionale et quasi étnica, ma come una modalità di sentiré et di esprimersi che trova la sua giustificazione in un particolare e mediato intendimento artístico" (53). No debe resultar extraño, entonces, que estos ambientes afloren o dominen en algunas de las "descripciones ecfrásticas" de sus relatos legendarios --y en general, en toda su obra narrativa--, en un escritor que rompe deliberadamente múltiples convenciones, incluida la de los géneros, acudiendo a su estilo plástico y musical -que no podía ser de otra manera-- para pintarle al lector, incluso con pinturas sonoras, y en general sensoriales, lo que deseaba transmitir; aunque en su caso era mucho más importante el "cómo" lo deseaba transmitir. Por eso, cuando entramos en contacto con las Leyendas, en las que domina una suerte de culto por el pasado y una marcada tendencia a mostrarnos sus cuadros plásticos y sonoros mediante la palabra, nos damos cuenta de que con tales relatos entramos en un universo distinto y de una gran originalidad. Así es que, indicar la estrecha relación en el costumbrismo entre pintura y texto resulta, evidentemente, una obviedad; y en el caso de Bécquer, una aclaración innecesaria. Sólo me voy a permitir, a un nivel 
teórico, la mención, por un lado, de la necesidad del "cuadro", que parecieron sentir los primeros autores de este movimiento; y por otro, la utilización del referente estrictamente pictórico, sin apenas acudir a la expresión textual. Se trata de un recurso que bien podríamos definir como pre-costumbrista, y que podría haber definido la tónica --y hasta el nombre--del posterior "cuadro de costumbres".

Para Bécquer, desde luego, el concepto de "folclor" --tan asociado al costumbrismo-- tal y como se le conoce hoy, no había alcanzado todavía el grado de definición que alcanzará tiempo después, aun cuando ya se comenzaba a utilizar el término. Sin embargo, lo folclórico y, en general, el costumbrismo, comparte características comunes con su forma de trabajar. Para él, su labor de tomar apuntes, notas y observaciones --tanto de forma textual como gráfica-- sobre tipos, costumbres y paisajes, era parte de su modus operandi, tal y como hemos comprobado hasta ahora en este trabajo. De su condición de precursor, dan fe los hechos: Cuando Fernán Caballero publica sus Cuadros de costumbres, en 1862, entre otras obras contemporáneas que abordan el género, ya Bécquer había iniciado esa práctica, desde mucho tiempo atrás --por demás, muy en línea con su condición de pintor--, que terminaría por definir su estilo y su propósito artístico-literario. En la carta IV de Desde mi celda, Bécquer esboza esa intención: "[Y]a que ha llegado la hora de la gran transformación, ya que la sociedad animada de un nuevo espíritu se apresura a revestirse de una forma, debíamos guardar, merced al esfuerzo de nuestros escritores y nuestros artistas, la imagen de todo eso que va a desaparecer, como se guarda después que muere el retrato de una persona querida" ( $\underline{\text { Obras }}$ completas 410). 
En algunas de las leyendas --“El gnomo", "La cueva de la mora”, "El beso” y “La rosa de la pasión"-- el elemento costumbrista está presente, como lo ha estado en anteriores leyendas, aunque expresado con pinceladas breves, pero lo que caracteriza a estos relatos tradicionales es el eclecticismo en las atmósferas, en la composición del cuadro y en las técnicas narrativas, donde concurren ideas, valoraciones y formas de narrar disímiles; elementos que, sin embargo, Bécquer integra de forma coherente y cuyo resultado resulta armónico, a pesar de --o gracias a-- su carácter ecléctico. De esta forma, encontramos, junto a las recreaciones de tipos y costumbres --insertados casi siempre de forma aislada-- páginas de decidida inspiración poética, muy dentro del lenguaje becqueriano de poesía narrada; cuadros visuales y sonoros de gran vistosidad y plasticidad; así como escenas pintadas con una fuerte carga simbolista, como corresponden a un narrador de transición como Bécquer.

Parece ser, por el testimonio que han dejado algunos de sus contemporáneos y sus propias obras, que, entre 1863 y 1864 --años de creación de las leyendas mencionadas-- fue un período de intensa y variada actividad de Bécquer. A la par de su intensa labor periodística en El Contemporáneo, Bécquer escribe para La América y La Gaceta Literaria; redacta una zarzuela con Rodríguez Correa, y artículos de crítica con, al menos, otro colaborador; dibuja intensamente y escribe una rima, además de varias leyendas. Esto pudiera explicar, en parte, la confluencia de estilos variados en estos relatos legendarios, aunque quizás no sean sólo estas actividades las que hayan podido determinar el carácter ecléctico de las mismas, desde luego. 


\section{V.I. La pintura costumbrista en las Leyendas.}

“Maese Pérez el organista"3, la última de las leyendas escritas en 1861, reviste un interés especial, casi diría un triple interés, en la medida en que se reflejan en ella varios aspectos importantes. El primero de ellos, sin duda, es la ambientación de la Sevilla del Siglo de Oro (del siglo XVI, específicamente) --evocada desde la ciudad de mediados del siglo XIX-- mediante percepciones más auditivas que visuales. El segundo aspecto trata de la presencia en el cuadro II de lo que ya he llamado antes "pintura sonora o auditiva", con la descripción de la música del órgano; y el tercer aspecto se refiere a la trasposición literaria --o también traducción literaria-- del lenguaje popular sevillano; en la forma en que Bécquer lo percibe, elabora e incorpora al texto con las calidades inherentes a lo literario. El resultado es un verdadero ejercicio de "(re)creación ecfrástica, pero a partir de elementos auditivos que se refieren, casi en su totalidad, a las conversaciones entre feligreses en el habla local, que es distintivo del costumbrismo. Al respecto, Antonio de la Banda y Vargas afirma lo siguiente: "Todo, en fin, es sevillano y aun, si se quiere, Sevilla misma en la narración, ambiente e inspiración de esta deliciosa página de nuestra mejor literatura romántica" (132). A ello contribuye el hecho de que esta leyenda está escrita, al menos en parte, en forma de diálogo, por lo que facilita el uso del lenguaje popular sevillano en la trama, mediante el idiolecto costumbrista de las vecinas.

La primera referencia a la localización sevillana de la leyenda aparece en la introducción a la misma: "En Sevilla, en el mismo atrio de Santa Inés, y mientras esperaba a que comenzase la misa del gallo, oí esta tradición a una demandadera del 
convento" (217). En pocas palabras, Bécquer nos sitúa en el escenario de Sevilla, en la iglesia de Santa Inés y, además, nos aclara el carácter popular de la tradición. No hay duda de su enorme capacidad para resumir las "recreaciones", pero sin que éstas pierdan su fuerte carga descriptiva. En "Maese Pérez", la ambientación sevillana está dada, casi sin excepción, por la recreación del habla local. Las pinceladas históricas son breves: alusiones al "rey Felipe" (219), se refiere a Felipe II; a la rivalidad existente entre las familias de Alcalá y Medina Sidonia, sobre todo en el siglo XVI (219); a la presencia de la nobleza sevillana, por cuyos vestidos sólo es posible identificar la época. El nombre de algunos nobles, relacionados con la vida de Sevilla del Siglo de Oro, también contribuye a la localización temporal. En cuanto a la toponimia sevillana, ésta se encuentra determinada por detalles igualmente breves: una mención a la calle de Chicarreros; otra al arco --y convento-- de San Felipe Neri; la iglesia de Santa Inés; la Virgen Santísima del Amparo, que se venera en la parroquia de la Magdalena; y repetidas menciones del nombre de Sevilla, deliberadamente espaciadas. Sin embargo, la idea de conjunto de estas pinceladas sueltas de gran movimiento hace que el lector perciba dos cosas: que la acción tiene lugar en Sevilla, y que ésta ocurre durante el Siglo de Oro; pero si se suman los elementos aludidos, veremos que el efecto es sorprendente en comparación con las limitadas alusiones que emplea, lo cual es parte de su estilo narrativo, como hemos tenido oportunidad de comprobar. Esta economía de referencias es, sin embargo, estudiada. "El costumbrismo nos indicará siempre con una deliberada vaguedad la índole del escenario y la composición de las figuras, y nosotros completaremos el detalle de los accidentes según nuestra propia experiencia” (José Montesinos 34). Sin duda, la 
capacidad pictórica de Bécquer para abocetar escenas y personajes, como parte de su adiestramiento como dibujante, fue decisiva para componer estos escenarios, que suelen seguir un patrón compositivo.

Por otra parte, Bécquer utiliza el estilo directo --que ha empleado eficazmente en otras leyendas-- a través de un personaje de la trama, pero con el doble propósito de comunicar y mostrar al personaje en cuestión la información deseada. Al hacerlo, Bécquer le transmite idéntica información al lector-espectador, que la recibe doblemente: de forma textual y a través de las écfrasis. Así, se vale de una de las comadres para introducir este recurso: “¿Veis ese de la capa roja y la pluma blanca en el fieltro, que parece que trae sobre su bustillo todo el oro de los galeones de Indias? ¿Aquel que baja en este momento de su litera para dar la mano a esa otra señora que, después de dejar la suya, se adelanta hacia aquí, precedida de cuatro pajes con hachas? (218).

La finalidad de Bécquer, parece obvia, es la de presentar al lector los distintos personajes que van a intervenir en la composición del cuadro; y lo hace, acompañando a cada uno de ellos con elementos de color y de luz, que le sirvan para destacarlos, con lo cual facilita la descripción ecfrástica de los mismos. El diálogo de las vecinas continúa con las presentaciones: “¿Veis aquel que viene por debajo del arco de San Felipe, a pie, embozado en una capa oscura, y precedido de un solo criado con una linterna? ¿Reparasteis, al desembozarse para saludar a la imagen, en la encomienda que brilla en su pecho?" (218). En el primer caso, Bécquer coloca al personaje en relación con un monumento, el arco de San Felipe, y alumbra al personaje, al menos indirectamente, con la luz de la linterna del criado. En la 
segunda parte de la presentación de este personaje, Bécquer insiste en la condecoración que brilla --probablemente de oro--, en oposición a la oscura capa. La luz de la lámpara --que pudiera ser un eco del famoso cuadro de Goya sobre los fusilamientos-- justifica la iluminación del personaje en la oscuridad de la noche; un recurso, sin duda, pictórico. En la obra de Goya, el efecto dramático de la luz proyectada por la linterna actúa como un referente pictórico que, por contigüidad de efecto, parece proyectar el contraste deseado en la figura del personaje becqueriano. Por otro lado, la escuela costumbrista madrileña, más crítica que la andaluza, une la tradición goyesca al popularismo romántico, y "pone acento a la realidad histórica española con inclusión de todo el repertorio de fiestas y supersticiones, con especial atención a los tipos desaventurados y populares" (Cirisi Narváez 16), como es el caso de Maese Pérez. Técnicamente, además, la escuela madrileña evoluciona de una pincelada rápida y abocetada a un brillante y temperamental colorido; evolución que se hace también evidente en Bécquer.

Todo el capítulo I se centra, pues, en la presentación de la nobleza y la alta burguesía sevillanas, y Bécquer lo hace, individualizando a los personajes, a los que dota con elementos brillantes que identifican su pertenencia a los estratos más favorecidos de la sociedad. No hay duda de que su prosa plástico-sensorial actúa como el elemento capaz de sumergir al lector en la atmósfera sevillana de la época. Por otro lado, la presentación del espectáculo también prepara al lector para la aparición del personaje principal: Maese Pérez, el organista, hombre humilde y de gran sencillez en el vestir, que crea un fuerte contraste con las vestimentas y joyas de los concurrentes más adinerados, lo que, sin duda, contribuye a singularizarlo. 
Una vecina lo presenta a otra por medio del recurso de la pregunta directa: “ ¿No conocéis a Maese Pérez? Verdad es que sois nueva en el barrio" (220). De nuevo Bécquer, como en "Los ojos verdes" y en otros relatos, se sirve del desconocimiento del personaje por parte de la vecina para justificar la descripción de Maese Pérez, que incluye su condición de hombre humilde, dedicado y devoto, además de su situación de invidente, familia, proposiciones ventajosas de trabajo en otras parroquias, y hasta en la catedral. Bécquer nos pinta un completo retrato físico y moral del personaje --un tableau equivalente a la suma de la prosopografía y la etopeya-- que es a un tiempo pintura detallista y descripción textual.

Bécquer organiza el cuadro siguiendo sus pautas pictóricas de componer por planos. La colocación de los grupos, contribuye a crear, también en lo social, las diferencias de clase de los presentes. Por ello, su acercamiento artístico a la escena nos presenta de forma más sutil algunas consideraciones de comportamiento social. En un primer plano, se agrupan la nobleza y los personajes principales de la ciudad. La escena refleja un cuadro de intensa luz y color que despiden los trajes y las joyas de estos personajes, como muestras inequívocas de su condición social. En los planos del fondo, los más festivos, por el contrario, se acomoda --se agolpa, mejor-el pueblo, al que acompaña una verdadera sinfonía de sonidos de toda índole: cantos de villancicos, gritos desaforados, ruidos de panderos, sonajas y zambombas. Bécquer ha trazado aquí un cuadro sonoro de gran expresividad y movimiento, con efectos teatrales, por lo exagerado, y cinematográficos avant la lettre, por el movimiento, como preámbulo al capítulo II, donde la pintura sonora alcanzará niveles de expresión realmente sorprendentes. 
Esta dualidad, que ya hemos visto en otras leyendas como parte de su quehacer compositivo, coloca a los personajes del cuadro en planos yuxtapuestos, quizás para expresar mejor la división pictórica --y hasta social-- de los grupos: luz, color y silencio, en un ángulo, bullicio, expresividad y tonos encontrados, en el otro. En el capítulo II, Bécquer ilustra con un poema en prosa la música del órgano, tal y como hace en "El Miserere" con el canto coral religioso. De acuerdo con Robert Pageard, "Bécquer expresa aquí sin énfasis su pesar de no haber estudiado música" (323), aunque como ya hemos indicado, poseía ciertas cualidades de apreciación musical, que le permitieron componer sus cuadros sonoros con soltura y poder evocador. Las manifestaciones de este tipo incluyen un variado registro acústico. Con relación al ruido generado por el pueblo, Pascual Izquierdo acota que "[de] la plebe no proceden más que manifestaciones sonoras carentes de armonía. De la nobleza, destellos luminosos de joyas y vestimentas" (58). Puede inferirse de este comentario, que la armonía de unos (los ricos) se opone a la falta de armonía de los otros (los pobres), lo que reafirma las dualidades utilizadas por Bécquer en la composición del cuadro; sonoro en este caso.

El capítulo II comienza, por otro lado, con la descripción ecfrástica de un cuadro de interior que dividiremos en dos planos perfectamente identificables. En un primer plano, Bécquer esboza la pintura del interior del templo y nos describe al primer grupo:

La iglesia estaba iluminada con una profusión asombrosa. El torrente de luz que se desprendía de los altares para llenar sus ámbitos chispeaba en los ricos joyeles de las damas que, arrodillándose, sobre 
los cojines de terciopelo que tendían los pajes y tomando el libro de oraciones de manos de sus dueñas, vinieron a formar un brillante círculo alrededor de la verja del presbiterio.

Junto a aquella verja, de pie, envueltos en sus capas de color galoneadas de oro, dejando entrever con estudiado descuido las encomiendas rojas y verdes, en la una mano el fieltro, cuyas plumas besaban los tapices; la otra sobre los bruñidos gavilanes del estoque o acariciando el pomo del cincelado puñal, los caballeros... parecían formar un muro destinado a defender a sus hijas y a sus esposas de la plebe. (222-23)

Saltan a la vista algunas características de la llamada "pintura de casacón", una pintura muy apreciada por el gusto decimonónico, por cuanto ofrecía unas supuestas imágenes de la vida cotidiana del siglo anterior, y unas recreaciones idealizadas llenas de lujo del pasado histórico, pero con concesiones al exotismo andaluz. Fortuny y el sevillano Jiménez de Aranda, contemporáneo de Bécquer, son los dos mejores exponentes en España de este género. Bécquer se vale, además, de algunas técnicas de la pintura prerrafaelista relativas a la luz que ilumina a partes iguales --contrariamente a los efectos del foco de luz, mucho más propios de Murillo--, y en la representación casi fotográfica, incluso de objetos pequeños, sobre todo en aquellos situados en el primer plano; lo que anuncia una evolución lenta hacia el realismo. Las pinceladas de color, los rojos y verdes de las encomiendas, están reforzadas por imágenes indirectas de color: plumas, fieltro, tapices, bruñidos gavilanes, cincelado puñal, nos remiten a referentes multicolores, pero, sobre todo, a 
las imágenes que cada uno de los lectores puede recrear en la mente, lo que refuerza la descripción ecfrástica.

En la segunda parte, en el plano del fondo, aparece el cuadro sonoro del pueblo:

Ésta [la plebe], que se agitaba en el fondo de las naves con un rumor parecido al del mar cuando se alborota, prorrumpió en una aclamación de júbilo, acompañada del discordante sonido de las sonajas y los panderos, al mirar aparecer al arzobispo, el cual, después de sentarse junto al altar mayor, bajo un solio de grana..., echó por tres veces la bendición. (223)

En la descripción del pueblo, sin embargo, afloran los detalles de la escuela andaluza, con los que Bécquer nos pinta un mundo amable donde el tipismo y la diversidad confluyen en una pintura decididamente costumbrista. De acuerdo con Cirici Narváez "fácil era de prever en una tierra donde la tradición y peculiaridad de lo andaluz se hundía en su propio pasado histórico, y cuyo repertorio iconográfico, fiestas y bailes, vestuario, usos y costumbres, personajes y tipos populares, entre la verdad y la leyenda, se presentaba ante el resto de la sociedad como un mundo insólito y extraordinario" (16); un mundo que, a pesar de la adopción madrileña, era el suyo, el de su infancia y adolescencia, el mundo de los Domínguez-Bécquer. No hay duda, por otro lado, de que Bécquer quiere hacer prevalecer el cuadro sonoro en esta descripción de gran movilidad, quizás con la única excepción del "solio de grana", que alude al color eclesiástico. Pero, la "sonoridad" es, sin duda el gran intérprete de este capítulo: 
Las cien voces de los tubos de metal resonaron en un acorde majestuoso y prolongado, que se perdió poco a poco, como si una ráfaga de aire hubiera arrebatado sus últimos ecos. A este primer acorde que parecía una voz que se elevaba de la tierra al cielo, respondió otro lejano y suave, que fue creciendo, creciendo, hasta convertirse en un torrente de atronadora armonía. Era la voz de los ángeles que, atravesando los espacios, llegaba al mundo.

Después, comenzaron a oírse como unos himnos distantes que entonaban las jerarquías de serafines. Mil himnos a la vez, que al confundirse formaban uno solo que, no obstante, sólo era el acompañamiento de una extraña melodía, que parecía flotar sobre aquel océano de acordes misteriosos, como un jirón de niebla sobre las aguas del mar. (224)

Bécquer también renuncia al color en la descripción de una serie de sucesivos cuadros sonoros, de los que el anterior es sólo un fragmento, con la finalidad de subrayar el dramatismo de la interpretación musical del órgano; y, por otra parte, demandar una mayor atención auditiva del lector. La sucesión de cuadros conforma, a su vez, un gran lienzo sonoro que Bécquer elabora sobre la base de sonidos y frases musicales, pero también de pausas. La expresión sonora contiene elementos de variaciones en la velocidad, (rápido-lento), de intensidad (fuertesuave), así como diversidad de timbres. La comparación con imágenes de ángeles y serafines, y la referencia al cielo, pretenden evocar en la imaginación del lector la naturaleza celestial de la música religiosa, a la que Maese Pérez parece inyectar una 
particular pasión divina. No es casualidad, opinamos, que Bécquer lo diseñe como "un santo" (220) y lo pinte con cualidades extraordinarias como intérprete del instrumento, aun después de muerto, lo que realza la presencia de Dios en la ejecución del instrumento musical. La recreación de la luz, además, contribuye a destacar la atmósfera religiosa de la escena, muy a tono con la pintura religiosa barroca y, en especial, de Murillo.

Sobre ese aspecto, Pascual Izquierdo ha destacado la relación entre luz y sonido en unas imágenes de gran contenido lírico: “Luz y sonido como elementos de un escenario pictórico y teatral. Luz como insonoro complemento del sonido. Sonido como invisible trasfondo del que emerge la música, culminación armónica" (Leyendas 59). Es interesante esta relación enunciada por Pascual, toda vez que establece un obligado diálogo inter-artístico entre el referente visual y el auditivo -que es uno de los propósitos de Bécquer--, siendo la presencia de este último referente particularmente importante en esta leyenda, por el papel que juega la música; es decir, por lo que significaban aquellos sonidos prodigiosos de Maese Pérez para los asistentes a la misa, y para el pueblo.

Por otra parte, las correspondencias música-pintura ya habían sido objeto de análisis por los románticos. Novalis, que como es sabido es una influencia destacada en la obra de Bécquer, había enunciado que "la unidad del cuadro... descansa en relaciones fijas, como la unidad de la armonía musical" (Russomanno 37). Además, Bécquer, que compartía sus conocimientos pictóricos con su afición a la música, pudo esbozar ciertas relaciones entre una y otra, quizás siguiendo la línea de que para poder "ver" un texto es también necesario "escucharlo"; con lo que parece 
buscar algo más en esa relación entre "la mirada" y "el oído". Siguiendo esta línea de análisis, quizás podría afirmar, incluso, que si los colores y las formas pueden "escucharse" --en algo más que a un nivel teórico-- también los sonidos pueden "verse", igualmente, en las mismas condiciones. La prosa de Bécquer, conviene destacarlo una vez más, es una prosa poética --o poesía en prosa, como otros prefieren-- y, como tal, abierta a sugerentes analogías, como las que establece entre música y pintura. Es posible que Bécquer estuviera en busca de un estilo que agrupara todo un universo de percepciones, sobre todo las visuales y auditivas -algo en lo que había estado trabajando desde su adolescencia--, y que, finalmente, lo halló en las Leyendas.

En los capítulos III y IV, Bécquer despliega un interesante "cuadro de costumbres"; y lo pinta a través del dialecto sevillano que utilizan las comadres -personajes que funcionan como narradores de ciertas partes de la trama, dentro del texto literario-- aunque sin la evocación de imágenes sensoriales, quizás con la intención de dejar espacio al elemento sobrenatural y fantástico que cierra la leyenda. Bécquer, además, logra darle "forma literaria" al habla popular de estas gentes, --esto es, trata de convertir en materia literaria toda la riqueza lingüística regional de que se vale--, y lo hace con un gran sentido del equilibrio y de la belleza. Al respecto, Bécquer vierte en esta leyenda ese interés por lo popular del llamado "neopopularismo"4, una corriente del siglo XIX que exaltaba los valores populares; incluso se llega a escribir literatura seria en variantes dialectales como ha hecho Bécquer con el habla sevillana. No podemos descartar esta influencia en la escritura de "Maese Pérez". 


\section{V.2. Las fuentes eclécticas en algunas leyendas.}

Bécquer elabora sus últimas leyendas sobre la base de múltiples ideas, estilos y teorías, a fin de obtener información complementaria para sus temas y construcciones narrativas. También, con el propósito de conciliar las diferentes corrientes y teorías existentes, tomando de cada una de ellas lo que consideraba aceptable a sus propósitos estéticos. No hay en este esfuerzo final, sin embargo, ningún propósito de suscribirse al eclecticismo historicista, que permitió una ruptura con el rígido esquema académico al lograr una mayor libertad creativa y compositiva, algo que ya había explorado en las leyendas de trasfondo historicista medieval, e incluso en Maese Pérez al rescatar el ambiente sevillano del siglo XVIII.

Creemos, más bien, que Bécquer se encontraba en un momento crucial de su creación, sintiéndose mucho más seguro ante la posibilidad de elegir aquella opción que a su gusto mejor se adaptase a sus fines, pudiendo construir estos relatos a partir de fuentes variadas sin aparentes problemas de coherencia estilística.

"El gnomo"5, por ejemplo, es una leyenda totalmente ideada, a la que Bécquer incorpora algunos elementos del folclor europeo con la finalidad de otorgarle al relato rasgos de tradición popular o leyenda. De esta manera, Bécquer se vale de un anciano aragonés que aconseja a las jóvenes no acudir a la fuente cercana al atardecer, puesto que allí viven unos seres misteriosos, los gnomos: seres que adoptan la apariencia de hombres muy pequeños o de luces azuladas que seducen a las jóvenes, prometiéndoles las riquezas que atesoran en sus cuevas. Hay varias fuentes sobre éstos en la literatura europea. Los hermanos Grimm los habían incluido en sus historias del folclor alemán. En Francia, reciben el nombre de 
"lutins", y comprenden un número de pequeños genios --malévolos y benévolos-que habitan en la cima de los montes, las cuevas o las fuentes de agua. En los Pirineos existen sus equivalentes bajo el nombre de "duendes", aunque reciben un número considerable de nombres distintos: "follet, fulet, ventolin, minairóns, petits" (Benítez 156), entre otros. Según Paul Sébillot, "les lutins ont la vertue de changer leur apparence" (119). En la obra de Heine, un poeta tan admirado por Bécquer, también encontramos la descripción de estos extraños seres, específicamente en su Romancero (Cit. por Benítez 157).

Es muy posible que algunas de estas fuentes --o quizás todas ellas-- hayan llegado a Bécquer por una u otra vía. Es sabido su contacto con la obra de los Grimm, y, por otro lado, parece lógico suponer que algún texto en francés sobre estos seres haya podido encontrarse en la copiosa biblioteca de su madrina o en las redacciones de los periódicos para los que trabajó. En cuanto al contacto con los relatos aragoneses, debemos suponer que su relación con éstos fue mucho más probable, bien porque eran leyendas españolas o por su condición de periodista versado en este género. La complejidad de la estructura del relato, que mencionan algunos críticos, ha llevado a considerar esta leyenda como costumbrista --aunque sólo sea en parte--, pero con características muy especiales, toda vez que concurren en ella otros elementos que la clasificarían dentro de otros grupos de leyendas.

La primera descripción costumbrista --la de un “tipo"-- es la del tío Gregorio, que para muchos es una "viñeta costumbrista": "El tío Gregorio era el más viejecito del lugar. Tenía cerca de noventa navidades, el pelo blanco, la boca de risa, los ojos alegres y las manos temblonas. De niño fue pastor; de joven, soldado. Después 
cultivó una heredad, patrimonio de sus padres, hasta que, por último, le faltaron las fuerzas y se sentó a esperar la muerte que ni temía ni deseaba" (289-90).

Bécquer nos pinta un cuadro con unas pocas y rápidas pinceladas. Llama la atención cómo Bécquer recrea el transcurso de la vida de Gregorio, que resume en un par de líneas, con una concreción y economía de líneas sorprendentes. La prosopografía es breve e indiscutiblemente costumbrista: "noventa navidades", "boca de risa", "ojos alegres" y "manos temblonas". Cuando se piensa en el arte japonés, tan revalorizado en el siglo XIX, y comparamos este retrato con la llamada estampa japonesa (el llamado Ukiyo-e), no puede uno dejar de pensar en las coincidencias en cuanto a los escasísimos recursos pictóricos de que se valieron estos artistas japoneses para expresar sus ideas, el humor y ternura en el tratamiento de los temas, así como el dibujo nítido y seguro en sus creaciones; elementos todos que confluyen en la precisa descripción o pintura del "tío Gregorio", elaborada por Bécquer.

Por otra parte, Bécquer elabora un suntuoso cuadro de los tesoros que ocultan los gnomos en sus cuevas, pero para ello recurre al clásico recurso de un personaje-narrador, un humilde pastor en este caso, que descubre de forma casual la entrada de una cueva. Franqueada ésta, el interior de la misma termina por descubrirle--y mostrarle al lector-- los tesoros que abriga. Desde luego, también, como ocurre en los cuentos clásicos de hadas, duendes y otras criaturas fantásticas, la intromisión en los dominios de estos extraños personajes, casi diabólicos, se paga con la vida; pero antes de morir, el pastor refiere lo hallado a un grupo de sus conciudadanos, lo que justifica la recreación ecfrástica del tesoro: 
El suelo, la bóveda y las paredes de aquellos extensos salones, obra de la naturaleza, parecían jaspeados como los mármoles más ricos; pero las vetas que los cruzaban eran de oro y de plata, y entre aquellas vetas brillantes se veían, como incrustadas, multitud de piedras preciosas de todos colores y tamaños. Allí había jacintos y esmeraldas en montón, y diamantes, y rubíes y zafiros y, qué sé yo, otras muchas piedras desconocidas que él no supo nombrar, pero tan grandes y tan hermosas, que sus ojos se deslumbraron al contemplarlas. (292)

Esta écfrasis becqueriana reviste características especiales. Parece ser que en la composición pictórica a la vista, el contorno exacto de la línea, esto es, de su dibujo, en términos pictóricos, no llega al lector-espectador. La sensación es de "una masa" de color y de luz. Los detalles del dibujo --o la línea del volumen, si se quiere-sólo se descubren a partir de la mención del objeto, es decir, cuando se recrean en la mente, pero no así en la pintura que muestra a los lectores. El hacinamiento de objetos valiosos, probablemente, hizo que Bécquer resolviera el efecto pictórico a la manera impresionista, pero no en el sentido del movimiento pictórico, sino en su sentido literal de darle al espectador una idea imprecisa, sin contornos, sin línea, en definitiva; una impresión delos colores, casi abstracta, en cierto sentido. La traducción colorista que es posible hacer en la mente, hace confluir en una masa informe los tonos dorados y plateados, los rojos y verdes brillantes, el rojo oscuro del jacinto y el azul de los zafiros, el intenso brillo de los diamantes y "otras muchas piedras desconocidas". La solución plástica de Bécquer, debemos reconocer, una solución avant la lettre, en términos estéticos, fue un gran acierto de racionalización 
pictórica que, como en otros casos, sorprende por su adelanto a las técnicas del fin de siglo, como ya hemos apuntado. Sin embargo, a fuer de resultar atrevido el comentario, ya un pintor español como Fortuny se planteaba e interpretaba en determinadas obras --que, según sus propias palabras, "pintaba para él mismo"-algunos de los logros posteriores de los impresionistas, sobre todo en el aspecto de la búsqueda del luminismo.

En un segundo cuadro secuencial que completa al anterior, el pastornarrador continúa la recreación ecfrástica de la pintura a la vista, según avanza por el interior de la cueva-galería. No hay duda de que Bécquer hace avanzar al personaje, lo hace detener para admirar el cuadro que tiene ante sí, y, finalmente, le pide que describa (narre y pinte) lo que "ve":

Había joyas de un valor incalculable, collares y gargantillas de perlas, y piedras finas, ánforas de oro de forma antiquísima llena de rubíes, copas cinceladas, armas ricas, monedas con bustos y leyendas imposibles de conocer o descifrar, tesoros, en fin, tan fabulosos e inmensos, que la imaginación apenas puede concebirlos. Y todo brillaba a la vez, lanzando unas chispas de colores y unos reflejos tan vivos, que parecía como que todo estaba ardiendo y se movía... Al menos, el pastor refirió que así le había parecido. (292-3)

Bécquer elabora esta descripción, siguiendo los parámetros de la anterior. La luz y el color siguen siendo los protagonistas, pero, a diferencia de la anterior, aquí el dibujo es más nítido, más limpio: collares, gargantillas, ánforas, copas cinceladas, armas, monedas con bustos; todo un inventario de objetos que se definen, tanto por 
el dibujo como por sus referentes mentales, lo que hace el cuadro más específico, aunque sin dejar a un lado los efectos de focos de luz, que concurren tanto en obras de Murillo como de Rembrandt. Bécquer señala, por otro lado, que la "imaginación" no puede concebir esas escenas; por lo tanto apela al sentido de la vista para corregir esa imposibilidad, haciendo creer al lector-espectador, aparentemente, que la écfrasis desplaza a la mente en la recreación del cuadro. El mecanismo es engañoso, pues la mente en el lector funciona como un "equipo revelador" de las imágenes. Como señalan Rosemary Geisdorfer y Carlos Feal en Painting on the page: "The work (the text, visual art or painting on the page), functions like a mirror in which the readers/spectators see themselves reflected. Individual affect is thus transferred onto the work of art, and we project our intrapsychic material onto the images that the artist convenes in his or her creation" (22). La contemplación de una obra de arte, como se ha probado, genera un abundante material de asociaciones inconscientes en el lector-espectador, que forman parte de su propia experiencia, y que se proyectan sobre el objeto visual contemplado, de forma tal que éste termina siendo el resultado del cúmulo de experiencias y valoraciones del lector-espectador.

El epígrafe III se inicia con un gran cuadro sonoro, precedido de un efecto crepuscular loreniano que actúa como viñeta romántica, a fin de otorgar a la escena del necesario ambiente de sombras: "La última luz del crepúsculo se había apagado en el horizonte y la noche comenzaba a cerrar de cada vez más oscura, cuando Marta y Magdalena... salieron del pueblo con dirección a la fuente misteriosa. La fuente brotaba escondida entre unos riscos cubiertos de musgo en el fondo de una larga alameda de árboles" (298-9). Es una descripción breve, una viñeta, pero evocadora 
de un paisaje ideal que nos remite a "Los ojos verdes", por el halo de misterio que rodea a la fuente, origen de la tragedia. Sin embargo, el "cuadro sonoro" que sigue es uno de las estampas más logradas de esta leyenda:

Después que se fueron apagando poco a poco los rumores del día y ya no se escuchaba el lejano eco de la voz de los labradores que vuelven, caballeros en sus yuntas, cantando al compás del timón del arado que arrastran por la tierra; después que se dejó de percibir el monótono ruido de las esquilillas [sic] del ganado, y las voces de los pastores, y el ladrido de los perros que reúnen las reses, y sonó en la torre del lugar la postrera campanada del toque de oraciones, reinó ese doble y augusto silencio de la noche y la soledad, silencio lleno de murmullos extraños y leves, que lo hacen aún más perceptible. (299)

La pintura de sonidos, ruidos y música que esboza Bécquer en este fragmento, resume, también en lo sonoro, su particular forma de recrearlas imágenes --en este caso auditivas-- por medio de la palabra. Los rumores, los ecos de voces, cantos acompasados, el arado que se arrastra, el ruido de esquilillas, las voces de los pastores, los ladridos, las campanadas, son elementos compositivos del cuadro auditivo, pero también, del cuadro visual. A estos sonidos se yuxtaponen, dentro de su ya peculiar forma de componer en dualidades, los silencios de la noche y la soledad, así como los paradójicos murmullos del silencio, que actúan como contrapuntos de la sonoridad. No hay duda que el Bécquer-músico ha compuesto una suerte de polifonía musical con los sonidos del paisaje, el compás de la "cantata" de los labradores, y el uso de los "ecos" como elementos --por demás muy utilizados 
en las polifonías barrocas-- que se repiten en la pieza musical, pero con menor volumen, y cuyo resultado final es asombroso por el poder evocador de estas imágenes.

En cuanto a la composición de la obra, siguiendo la construcción dual que lo caracteriza, Bécquer introduce dos personajes en la trama: las hermanas Marta y Magdalena, que, a nivel simbólico, representan dos opuestos: materia y espíritu, agua y viento, frialdad calculadora y fragilidad sentimental. Para Rica Brown, en esta leyenda, la "parte más bella y más poética, es la especie de diálogo doble, en el que dos elementos de la naturaleza, el agua y el aire, vienen a representar las dos voces que tratan de seducir a las muchachas, y la contestación que cada una de ellas da a estas voces" (207).

Sin duda, Bécquer, dentro de ese eclecticismo estructural al que nos hemos referido antes, incluye un diálogo poetizado en medio de la narración que ayuda a crear una atmósfera fantástica, de cuento de hadas. Con la desaparición de Marta, encarnación de lo material, y el regreso de Magdalena, "pálida y llena de asombro", que representa lo espiritual, Bécquer parece decirnos de que aún hay esperanzas para los valores del esp. "El gnomo", en esencia, "es una declaración de fe en la vida del espíritu, una afirmación de la voz interior, casi rituimperceptible, pero cuya melodía es casi preferible a cualquier música terrestre" (Brown 207).

En "La cueva de la mora"6, Bécquer elabora algunos cuadros ecfrásticos de singular belleza, aunque debemos afirmar que aquí éstos aparecen como escenografías, como cuadros de fondo de la historia, pero sin la importancia protagónica que alcanzan en otras leyendas. Aun así, estos cuadros le otorgan a las 
escenas el tono y el valor deseados para enmarcar las acciones de los personajes. De acuerdo con Pascual Izquierdo, en esta leyenda "falta el lirismo poético y sensorial, [y] el aleteo de la imaginación“(77); "todo es acción y movimiento" (78), lo que no excluye los valores plásticos de los cuadros, a pesar de la aseveración de Izquierdo.

Así, Bécquer comienza el trazado del escenario mediante imágenes de un gran contenido pictórico o "pictorialista", en lo que tiene este término de nostálgico:

[S]obre unas rocas cortadas en pico, a cuyos pies corre el río Alhama, se ven todavía los restos abandonados de un castillo árabe, célebre en los fastos gloriosos de la reconquista por haber sido teatro de grandes y memorables hazañas, así por parte de los que lo defendieron como los que valerosamente clavaron sobre sus almenas el estandarte de la cruz. De los muros no quedan más que algunos ruinosos vestigios; las piedras de la atalaya han caído unas sobre otras al foso y lo han cegado por completo; en el patio de armas crecen zarzales y matas de jaramago; por todas partes adonde se vuelven los ojos no se ven más que arcos rotos, sillares oscuros y carcomidos; aquí un lienzo de barbacana, entre cuyas hendiduras nace la yedra; allí un torreón que aún se tiene en pie como por milagro; más allá los postes de argamasa con las anillas de hierro que sostenían el puente colgante. (305-6)

La belleza del conjunto es innegable. Bécquer se vale una vez más de sus vastos conocimientos de arte para elaborar un cuadro con un delicado equilibrio entre la técnica y la propuesta artística; pero Bécquer también apela a su capacidad 
de observación ante las ruinas de muchos edificios que visitó durante sus frecuentes paseos por el campo, casi siempre junto a su hermano Valeriano; algo que aflora en esta leyenda. El vocabulario arquitectónico era conocido por Bécquer, como ya hemos explicado con anterioridad, y se deben, por una parte, a sus estudios de arte en Sevilla, así como a la copiosa información que reunió para la Historia de los templos de España. Más de un paisaje se podría ver reflejado en este cuadro (sobre todo a paisajistas andaluces barrocos con unos pocos personajes), pero no faltan las posibles alusiones al paisaje romántico desprovisto de la figura humana, esto es, desantropomorfizado, como en muchos de los paisajes becquerianos. Esta ausencia reforzaba, por un lado, la idea de abandono y soledad; tonos muy acordes con los temas de las Leyendas. Por otro lado, nos habla indirectamente de un hombre que está ausente del paisaje, porque, como refiere Argullol, "ha perdido definitivamente su centralidad en el universo y su amistad con la naturaleza" (La atracción del abismo 15).

Con relación a las ruinas, Bécquer continúa aquí con su apreciación histórica sobre éstas. Como señala también Argullol: "Lo peculiar y fecundo de la 'ruina romántica' es que de ella emana este doble sentimiento: por un lado, una fascinación nostálgica por las construcciones debidas al genio de los hombres; por otro lado, la lúcida certeza , acompañada de una no menor fascinación, ante la potencialidad destructora de la Naturaleza [sic] y del Tiempo [sic]" (23). Las plantas invasivas de las ruinas son, básicamente, jaramagos, zarzales, yedras; y constituyen las escasas pinceladas de color que Bécquer utiliza para otorgarle cierta vida a las ruinas, un recurso que ya ha utilizado antes. También, con el propósito de acentuar el 
contraste entre vida y muerte, y entre pasado y presente en el cuadro; aspectos que enfrentan la historia pasada con la historia presente, unidas por la leyenda.

Todavía hay en esta leyenda algunos cuadros de interés; son cuadros extáticos, de menor desarrollo individual, pero subordinados a un escenario más complejo que les otorga sentido de conjunto. Estos pequeños cuadros --una posible reminiscencia de las "tablitas" o tableautins de José Bécquer-- aparen casi siempre insertados como escenas aisladas, en los que, sin embargo, aparecen algunos elementos arquitectónicos que constituyen el objetivo e interés de los personajes:

Durante mi estancia en los baños, ya por hacer ejercicio que, según me decían era conveniente al estado de mi salud, ya arrastrado por la curiosidad, todas las tardes tomaba entre aquellos vericuetos el camino que conduce a las ruinas de la fortaleza árabe y allí me pasaba las horas y las horas escarbando el suelo por ver si encontraba algunas armas, dando golpes en los muros a ver si sonaba a hueco y sorprender el escondrijo de un tesoro. (306).

Quien nos habla es la voz narrativa del relato, que aparece con tintes autobiográficos del propio Bécquer, pues alude a su enfermedad y a sus curas de reposo y largos paseos en el campo. Como sabemos, Bécquer solía llevar, durante sus paseos regulares, una libreta de apuntes en los que realizaba algunos bocetos del natural, que luego le servían para sus recreaciones ecfrásticas, modus que incluso avala "Tres fechas", entre otras narraciones autobiográficas. No dudamos que, también en esta ocasión, los apuntes de Bécquer se hayan incorporado al cuadro, pues sugiere eso, un apunte o boceto, más que una obra elaborada. La 
mención de las ruinas árabes--un elemento invisible en la composición--, funge, sin embargo, como el "peso visual" de la composición.

Hay otros cuadros más breves, pero todos derivan del cuadro principal que hemos analizado. Por ejemplo: “Cuando el castillo del que ahora sólo restan algunas informes ruinas, se tenía aún por los reyes moros, y sus torres, de las que no ha quedado piedra sobre piedra, dominaban desde lo alto de la roca en que tienen asiento todo aquel fertilísimo valle que fecunda el río Alhama, tuvo lugar, junto a la villa de Fitero una reñida batalla" (308). No hay aquí elementos nuevos que difieran de las descripciones anteriores, pero la presencia de las ruinas en el paisaje, lejos de ser derivativas, ayudar a conformar un cuadro de conjunto, mediante estos cuadros extáticos, que tienen un valor pictórico dentro de la narración. Afloran aquí destellos historicistas de la cultura islámica, que resultan de gran importancia para situar la acción de la leyenda.

Sin embargo, lo que hace distinta a esta leyenda, casi diríamos única, de entre todas las que escribió, es la presencia de los datos biográficos de Bécquer en el relato, la alusión a la enfermedad que padecía, y al reposo que, por etapas, se veía obligado a guardar. El hecho de que el narrador pueda identificarse con el autor, con todas las reservas y limitaciones que impone la ficción, le añade a la trama, sin duda, un elemento novedoso: el valor autorreferencial, esto es, la pintura de un autorretrato. El final de la leyenda resume, de igual manera, la dualidad amormuerte, tan romántica y tan becqueriana, además. Pero, como casi siempre, el amor tiene una fuerza regenerativa, el desenlace presenta la conversión como elemento regenerador. 
Desde el punto de vista temporal, lo cual es casi una excepción, "El beso (Leyenda toledana)"8 recrea un tiempo mucho más cercano al autor. Tanto es así, que resulta la leyenda menos legendaria, pero también la más novelesca; características que la definen como muy novedosa con relación a las otras leyendas becquerianas. Están presentes, eso sí, descripciones ecfrásticas de gran riqueza plástica y abundantes referencias a la estatuaria religiosa, dentro del escenario arquitectónico que las enmarca. Por último, como rasgo distintivo de esta leyenda, me referiré a la "teatralidad" de algunas de las escenas, y al recurso de incluir el cuadro dentro del cuadro, que son características de una gran movilidad dentro de la composición pictórica, quizás llevado por su actividad teatral entre 1862 y 1863. El escenario que inicia la leyenda es la histórica Toledo, una ciudad que le era muy entrañable a Bécquer, y cuyos monumentos, sobre todo los religiosos, estudió a fondo. El primer capítulo comienza con alusiones al Alcázar de Carlos V, a la casa de Consejos, a la Puerta del Sol, a la plaza de Zocodóver, y a San Juan de los Reyes, pero de forma anecdótica, sólo para argumentar que servían de alojamiento a las tropas francesas de ocupación, y como mención, además, al saqueo de algunos de estos edificios emblemáticos ${ }^{9}$. Sobre esto, tenemos el primer cuadro:

[L]a iglesia está totalmente destartalada: en el altar mayor pendían aún de las altas cornisas los rotos jirones del velo con que lo habían cubierto los religiosos al abandonar aquel recinto; diseminados por las naves veíanse algunos retablos adosados al muro, sin imágenes en las hornacinas; en el coro se dibujaban con un ribete de luz los extraños perfiles de la oscura sillería de alerce; en el pavimento, 
destrozado en varios puntos, distinguíanse aún anchas losas sepulcrales llenas de timbres, escudos y largas inscripciones góticas, y allá a lo lejos, en el fondo de las silenciosas capillas y a lo largo del crucero, se destacaban confusamente en la oscuridad, semejantes a blancos e inmóviles fantasmas, las estatuas de piedra que, unas tendidas, otras de hinojos sobre el mármol de sus tumbas, parecían ser los únicos habitantes del ruinoso edificio. (350)

La desolada descripción del interior de la iglesia tiene la intención de mostrarnos el saqueo perpetrado por las tropas francesas, y lo hace a un ritmo cadencioso, enfocando las distintas áreas, como lo hiciera una cámara. La recreación ecfrástica comienza en al altar y se va moviendo hacia otros lugares del templo: los retablos de las naves, el coro, la sillería y el pavimento, siguiendo el recorrido de la cámara, que termina por fijar la lente en los monumentos funerarios, únicos "sobrevivientes" del saqueo, como para reafirmar, quizás irónicamente, las imágenes de muerte presentes en el templo. No hay ni una sola pincelada de color, ni siquiera algún elemento compositivo que pueda remitirnos a su colorido referente. Es obvio que Bécquer quiere destacar la atmósfera de desolación y tristeza del templo, privándolo de color, es decir, de vida. Así, a la falta de color se unen las referencias a mármoles y muros desnudos, lo que acentúa aún más esa atmósfera gris.

Para Bécquer, un artista de gran sensibilidad, que había demostrado, además, a lo largo de su vida, un interés por la salvaguardia de edificios y monumentos históricos, estas imágenes del saqueo a que fue sometida la ciudad durante la 
invasión de las tropas napoleónicas a España, una treintena de años antes de su nacimiento, tienen que haberle producido un fuerte impacto negativo. Por eso, afirma lo siguiente: "En la época en que se remonta la relación de esta historia, tan verídica como extraordinaria, lo mismo que al presente, para los que no sabían apreciar los tesoros del arte que encierran sus muros, la ciudad de Toledo no era más que un poblachón [sic] destartalado, antiguo, ruinoso e insufrible" (351). Por lo pronto, Bécquer desea hacer patente que, tanto en la época de los hechos como "al presente", la situación sigue siendo la misma para los que no muestran ningún grado de sensibilidad hacia la historia y sus monumentos; situación que pudo haberle afectado particularmente durante la preparación de la Historia.

Tengamos presente que del copioso trabajo de investigación realizado para este proyecto, sólo se publicó el primer volumen; casualmente, el dedicado a los templos de Toledo. No son desconocidas las múltiples trabas que recibió el proyecto, tanto en el orden económico como en la recepción del mismo por parte de los que, en teoría, debieron haber mostrado mayor interés en él; la cita destila algo de la amargura y frustración que lo embargó en aquel momento.

La escena del Zocodóver es, de acuerdo con la crítica, una de las que muestra mayores visos de teatralidad en las Leyendas de Bécquer. Se trata de la animación de la estatua ${ }^{10}$ de mármol en un monumento funerario, esto es, que cobra vida:

A la dudosa luz de la luna que entraba en el templo por el estrecho ajimez del muro de la capilla mayor vi una mujer arrodillada junto al altar... No podéis figuraos nada semejante a aquella nocturna y fantástica visión que se dibujaba confusamente en la penumbra de la 
capilla, como esas vírgenes pintadas en los vidrios de colores que habréis visto alguna vez destacarse a lo lejos, blancas y luminosas, sobre el oscuro fondo de las catedrales. (353-4)

La luz de la luna parece preparar la escena para ulteriores fantasías y ensoñaciones, como la visión del capitán de dragones. Bécquer apela, nuevamente, a la imposibilidad de los personajes a quienes narra la historia --y a los lectoresespectadores-- de imaginar una mujer como aquella. Sin embargo, terminará describiéndola hasta en sus más ínfimos detalles, siguiendo un patrón de describir a partir de la negación primera de poder hacerlo, pues la recreación que recibe el lector-espectador no es otra cosa que la écfrasis referencial. La comparación de la mujer con las vírgenes de las vidrieras parece acentuar la delicadeza y vivacidad de ésta, pues la enmarca con vidrios de colores, único acento colorista en la écfrasis. La sorpresa, sin embargo, es general cuando descubrimos --personajes y lectores-- que la mujer es de mármol, y por tanto se trata de un ser inanimado. No obstante, la imaginación permite la animación de las estatuas, lo cual encaja dentro de la estética romántica de dar vida a escenarios y monumentos medievales. Este tema contaba con antecedentes en la literatura europea y, en particular, en la española; fuentes en las que Bécquer pudo inspirarse.

La escena final del monasterio, al que todos acuden a admirar la mujer tiene visos de puesta en escena, de composición pictórica. Los personajes del cuadro son el capitán de dragones y sus amigos. El interior del monasterio es el escenario general y, dentro de éste, la capilla funciona como el escenario particular o principal (El recurso del cuadro dentro del cuadro). Las luces son tenues pues provienen de 
las lámparas que llevan los personajes. La ambientación del cuadro la componen los túmulos funerarios y las estatuas yacentes. La escena tiene lugar de noche. Una vez definidos estos elementos compositivos, Bécquer inicia el movimiento pictórico, como si se tratara de un director de escena llamando a la acción. Como el capitán de dragones había llevado algunas botellas de champagne, el efecto de éstas termina por accionar el trágico desenlace.

El cuadro escenográfico que nos presenta Bécquer del monasterio --y dentro de éste el cuadro de la capilla-- es sumamente representativo del período de la historia que pretende reflejar: la Edad Media. La escasa luz, por demás necesaria para definir la atmósfera sepulcral del relato, y la apariencia marmórea de las estatuas, completan el ambiente tenebroso del cuadro. No hay color, salvo el de los uniformes de los militares, el de la estatua de Elvira, cuya "piel", por momentos, cobra una coloración rosa y azulada como resultado del fuego de la hoguera que, además, proyecta reflejos dorados sobre las estatuas. Para el narrador --y esto es importante destacarlo-- las estatuas no están tan inertes, pues el escultor supo darles vida al crearlas. En clave artística, podemos deducir que Bécquer alaba la obra de los artistas como creadores de vida; y en ese sentido, el cuadro a la vista, posee movimiento, está impregnado de vida, en definitiva. El trágico final del capitán, a manos del marido de Elvira, cuya estatua yacente se halla junto a la de ella, supone la venganza de éste. El eco del don Juan de Tirso de Molina parece escucharse en esta leyenda. La animación de la estatua de Don Gonzalo pudo haber inspirado a Bécquer, aunque aquí pudiera tener igual o más peso la vida que se desprende de toda obra de arte, un ideal compartido por Bécquer. 
La última leyenda de Bécquer, la que cierra el ciclo creativo iniciado, probablemente, con "El caudillo de las manos rojas", es "La rosa de la pasión"11 (Leyenda religiosa)". Es ésta, también, la más polémica, por el marcado acento antisemita de su contenido, y por la presentación que nos hace Bécquer del judío Daniel Leví y de sus amigos, como seres despreciables y a la vez representativos de "los de su raza", como acota. La conversión de Sara al catolicismo, que confiesa a su padre en el último momento, y la escena de su "pasión", como evocación de la de Jesús, la eximen de los estereotipos presentados por Bécquer. Desde luego, esta visión prejuiciada y negativa se acoplaba a los moldes ideológicos de la España tradicional y persistentemente católica del siglo XIX y calzaban dentro de la propia visión tradicionalista católica de Bécquer.

Por otro lado, los cuadros ecfrásticos elaborados por Bécquer se centran en el paisaje arquitectónico toledano --aspecto este que dominaba, según ya hemos explicado-- y de las afueras de la ciudad, trazados con habilidad compositiva y detallista, salvo los retratos que hace Bécquer de Daniel y de Sara, fundamentados en descripciones etopéyicas: el de Daniel Leví, interpretado desde una perspectiva costumbrista por el marco del oficio que ejercía, y el de Sara, ejemplo del retrato romántico con antecedentes neoclásicos, como los retratos de Ingres.

El primer cuadro que nos presenta Bécquer tiene el propósito de localizar, mediante breves pinceladas, el escenario del relato, así como de marcar algunos rasgos del personaje: "En una de las callejas más oscuras y tortuosas de la ciudad imperial, empotrada y casi escondida entre la alta torre morisca de una antigua parroquia mozárabe y los sombríos y blasonados muros de una casa solariega, tenía 
hace muchos años su habitación raquítica, tenebrosa y miserable como su dueño, un judío llamado Daniel Leví" (363-4). Los elementos arquitectónicos, casi suntuosos por su procedencia, parecen tener el propósito de marcar, aún más, las diferencias entre éstos y la vivienda de Daniel Leví, en una abierta comparación de tintes negativos. La ausencia del color, al menos de los colores cálidos, es una característica del cuadro becqueriano que utiliza cuando quiere insistir en la atmósfera tenebrosa de un lugar.

Toledo, al igual que Sevilla, ofrecía espacios recoletos medievales que era necesario descubrir a través de la mirada romántica de un artista. Bécquer aprendió a extraer detalles realistas de la valiosa y abundante información sobre la ciudad, y no le importó, a la manera de un escenógrafo, combinar fragmentos aislados de la ciudad histórica para lograr el marco necesario. Ya lo hemos visto en "El beso" y en otros relatos. Esta correspondencia entre el color y el ambiente descrito, desde luego, no es casual; es incluso más artística que literaria, y responde a sus conocimientos de estos recursos, que son, sobre todo, pictóricos. Sin embargo, para presentarnos el cuadro de Sara, Bécquer utiliza una paleta mucho más colorista, como se desprende del interés ideológico de presentarla en oposición al padre:

Sobre la puerta de la casucha del judío, y dentro de un marco de azulejos de vivos colores, se abría un ajimez árabe, resto de las antiguas construcciones de los moros toledanos. Alrededor de las caladas franjas del ajimez y enredándose por la columnilla de mármol que lo partía en dos huecos iguales, subía desde el interior de la vivienda una de esas plantas trepadoras que se mecen verdes y llenas 
de sabia y lozanía sobre los ennegrecidos muros de los edificios ruinosos. En la parte de la casa que recibía una dudosa luz por los estrechos vanos de aquel ajimez, único abierto en el musgoso y grietado paredón de la calleja, habitaba Sara, la hija de Daniel. (364-5)

La presentación del área de la casa donde vive Sara --el único lugar adonde llega un poco de luz-- está, literalmente, enmarcada por azulejos de "vivos colores". En clave simbólica, la alusión no puede ser más clara. El verde de las plantas trepadoras, llenas de "sabia” y "lozanía" parecen acentuar el paralelo entre éstas y la vital juventud de Sara. El hecho de que el marco general esté constituido por "ennegrecidos y grietados muros de los edificios ruinosos", no hace más que destacar la belleza de Sara --dentro de un estilo decididamente pictórico-- que parece resurgir con vida de entre las ruinas de dos culturas extinguidas: la que representa la construcción árabe en la que habitan, por un lado, y la de su padre, por otro. El cuadro es, al mismo tiempo, el preludio del trágico final.

El muro "grietado" funciona como metáfora --también a un nivel plástico-- de las grietas que aparecen en la fe religiosa de Sara, y como imagen de la ulterior redención que, en clave pictórica, estará representada por la escena de la crucifixión. A Bécquer le interesa --como les interesará también a los pintores simbolistas-- la capacidad de sugerir, de establecer correspondencias entre los objetos y las sensaciones. El símbolo se convierte para él en un instrumento de comunicación, decantándose por figuras que trascienden lo material para devenir símbolos de un ideal. Sara pasa a ser --dentro de las coordenadas ideológicoreligiosas de Bécquer-- un símbolo del martirologio cristiano. 
A tenor de esta forma de aproximación, Margaret Persin ha afirmado lo siguiente:

The I/eye in the ekphrastic poem simultaneously takes in and projects an image that is both interior and exterior to the poem's boundary. The gaze of the poetic l/eye reflects and reflects upon power, ideology, authorship, gender, and genre, and draws the reader into the play of signifiers that results from the confrontation between the poem and the art object. (Getting the Picture 218)

La cita de Persin es importante en el sentido de que el cuadro recreado por Bécquer refleja valores no sólo del orden prosopográfico, sino, además, del etopéyico, y lo logra mediante la narración ecfrástica, lo que supone un logro indiscutible. El retrato de Sara es, en consecuencia, un cuadro ecfrástico, en la medida que supera y trasciende la mera descripción prosopográfica o etopéyica de la literatura para dejarnos una pintura abarcadora de características muy sutiles del personaje, activadas de forma ilimitada por la imaginación del lector-espectador. En más de un sentido, el "cuadro" de Bécquer es relevante:

Sara era un prodigio de belleza. Tenía los ojos grandes y rodeados de un sombrío cerco de pestañas negras, en cuyo fondo brillaba el punto de luz de su ardiente pupila como una estrella en el cielo de una noche oscura. Sus labios, encendidos y rojos, parecían recortados hábilmente de un paño de púrpura por las invisibles manos de un hada. Su tez era blanca pálida y transparente como el alabastro de la estatua de un sepulcro. Contaba apenas dieciséis años, y ya se veía grabada en su 
rostro esa dulce tristeza de las inteligencias precoces, y ya hinchaban su seno y se escapaban de su boca esos suspiros que anuncian el vago despertar del deseo. (365)

Los rasgos que hacen patente la procedencia pictórica de la (re)creación ecfrástica, están dados, primeramente, por la impresión plástica del conjunto. Luego, hay una serie de detalles que enfatizan ese origen: el "sombrío cerco de las pestañas"; el conocido "punto de luz" de Rembrandt, del que propio Bécquer nos habla en Desde mi celda; la descripción de los labios, casi volumétrica a la par que colorista; la comparación de la tez con el "alabastro de la estatua de un sepulcro", un material escultórico muy utilizado para la estatuaria. Los rasgos que le siguen son del dominio etopéyico, pero resumen su juventud y ansias espirituales con breves, pero acertadas pinceladas. El estudio de la cabeza de Sara --una práctica común entre los pintores, como ejercicio preparatorio-- tiene un halo espiritual que pocos pintores podrían alcanzar por la maravillosa mezcla de ternura, belleza y verdad. Quizás Bécquer se inspiró en "La novia judía" de Rembrandt --uno de sus artistas preferidos--, un cuadro del que emana, de acuerdo con la crítica, una profunda ternura.

Le sigue un cuadro romántico de ruinas de tendencia historicista. Esta orientación del cuadro, junto al sentimiento medieval, son también manifestaciones propias del presimbolismo ${ }^{12}$, e incluso del simbolismo, que las heredan del movimiento romántico. Bécquer presintió su deber en la reconstrucción de los vestigios del pasado que, para él, eran la historia. En ese sentido, Arnold Hauser afirma que "el reconocimiento de que hay una especie de destino histórico y de que 
nosotros somos precisamente lo que somos porque tenemos detrás a un determinado curso vital, es una conquista del Romanticismo" (173). Esta visión de Hauser ya había encontrado en Bécquer suficientes argumentos como para que formaran parte de su teoría artística, por demás presente en el cuadro al que me he referido:

Siguiendo el camino por donde hoy se encuentra la pintoresca ermita de la Virgen del Valle, y como a dos tiros de ballesta del picazo que el vulgo conoce en Toledo por la Cabeza del moro, existían aún en aquella época los ruinosos restos de una iglesia bizantina, anterior a la conquista de los árabes.En el atrio, que dibujaban algunos pedruscos diseminados por el suelo, crecían zarzales y hierbas parásitas, entre los que yacía, medio oculto, ya el destrozado capitel de una columna, ya un sillar groseramente esculpido con hojas entrelazadas, endriagos horribles o grotescos e informes figuras humanas. Del templo sólo quedaban en pie los muros laterales y algunos arcos rotos y cubiertos de hiedra. (370)

Los rasgos de carácter historicista aparecen ya en anteriores relatos, puesto que se trata de aspectos muy valorados por Bécquer, como ha quedado probado. Las referencias toponímicas tienen antecedentes reales y se hallan debidamente documentadas, aunque Bécquer, como sabemos, utiliza casi siempre, no la recreación, sino la (re)interpretación arqueológica. La descripción de los elementos arquitectónicos nos remiten a un estilo "anterior a la conquista de los árabes" -bizantino nos dice Bécquer-- aunque más bien se inscriben dentro de las 
construcciones alto-medievales, tanto por el origen mencionado como por la descripción de las tallas en los mismos. La ambientación de las ruinas, marcada por una vegetación invasiva, ayuda a acentuar su condición de edificio abandonado, de ruina, y, por tanto, a crear el escenario ideal para la acción de la leyenda.

El último cuadro ecfrástico es una (re)creación en clave simbólica del Gólgota, donde se llevará a cabo la crucifixión de Sara, siguiendo el canon de la pintura religiosa occidental y, quizás, algunos referentes pictóricos específicos como el grabado de "Las tres cruces", de Rembrandt, por la importancia lumínica de la escena:

Al rojizo resplandor de una fogata que proyectaba la forma de aquel círculo infernal en los muros del templo, había creído ver que algunos hacían esfuerzos por levantar en alto una pesada cruz, mientras otros tejían una corona con la rama de los zarzales o aplastaban sobre una piedra las puntas de enormes clavos de hierro. Una idea espantosa cruzó por su mente: recordó que a los de su raza los habían acusado más de una vez de misteriosos crímenes; recordó vagamente la aterradora historia del Niño Crucificado, que ella hasta entonces había creído una grosera calumnia inventada por el vulgo para apostrofar y zaherir a los hebreos. Pero ya no le cabía duda alguna; allí, delante de sus ojos, estaban aquellos horribles instrumentos de martirio, y los feroces verdugos sólo esperaban la víctima. (371)

El escenario no puede ser más sobrecogedor. No hay duda de que Bécquer se inspiró en algunas de esas obras que, desde el Medioevo, han recreado la crucifixión 
de Jesús en infinidad de estilos, asunto que no le era ajeno por su trayectoria artística. La luz de la fogata es de Rembrandt; no hay duda. Bécquer la había estudiado, probablemente durante su estancia en los talleres de Sevilla. Se trata de un estilo de iluminación en el cual las luces y las sombras están perfectamente definidas, como en este caso. El efecto es dramático, como corresponde a su origen barroco. Las referencias a la corona de espinas y a los clavos --"instrumentos de martirio", entre los que falta la lanza de Longinus--; más la visión de la cruz, colocada como el eje dominante de la composición pictórica, hacen presagiar un final trágico, aunque todavía no sabemos quién será la víctima. La posterior confesión de Sara ante su padre, en la que menciona a ese otro "padre" que ha conocido, "un padre todo amor para los suyos" (372), concreta, en ese momento, su condición de mártir de la fe, y sella su destino. La recreación de su crucifixión entre las ruinas del templo --evocación de la del Dios que había aceptado, a instancias del novio cristiano-- resultan en un cuadro de profunda emotividad, aunque permeado, a un nivel ideológico, por tintes racistas. No hay duda de que Bécquer se aprovecha de tópicos culturales denigrantes en referencia a los judíos, para así conseguir efectos receptivos en el lector-espectador de sus leyendas, un lector, por demás muy católico.

La práctica antisemita hunde sus raíces en la Antigüedad, ya que hay ejemplos concretos de este tipo de condena al judaísmo, tanto entre griegos como entre romanos, llegando hasta la época actual. La lista de argumentos o alegatos antisemitas que pudieron haber servido de fuentes a este relato --como la historia del niño sacrificado insertada en el relato como símil premonitorio-- es extensa, 
como prueba cualquier referencia al tema, y fue variando a lo largo del tiempo. El sufrimiento y la muerte de Sara en la cruz, en un claro símil con la de Jesús -acontecimientos que se conocen como "la pasión"-- representan los aspectos centrales de la teología cristiana, incluyendo las doctrinas de salvación y expiación. Bécquer nos pide interpretar la muerte de Sara, a un nivel simbólico, como una muerte en sacrifico expiatorio.

En líneas generales, estas cinco leyendas que he agrupado en este último capítulo, presentan características y peculiaridades distintas a las anteriores. Todas muestran, en mayor o menor medida, rasgos costumbristas, sobre todo la de "Maese Pérez", la más costumbrista de las cinco. El resto, presenta aspectos distintivos que obedecen a fuentes de influencia y recursos compositivos variados. En ese sentido, el término "ecléctico" puede agruparlas bajo un denominador común. De todas las Leyendas de Bécquer, con excepción de las dos leyendas indias y las analizadas en este capítulo, sólo las leyendas de trasfondo medieval y presencia casi constante de ruinas --elementos que también están presentes en algunas de las anteriores, pero de forma impresionista-- poseen características comunes en el tratamiento de los temas, los escenarios, los personajes, los efectos pictóricos y sonoros, y el vocabulario artístico, entre otros recursos. En todas, sin embargo, se halla presente la prosa plástica y sensorial, la aproximación a la pintura y la influencia de algunos artistas, cuyas obras, mediante la construcción de écfrasis referenciales genéricas, se encuentran reflejadas en sus descripciones. Con estas ideas en mente es que debemos abordar nuevas posibles lecturas de las Leyendas. Además, como hemos comprobado, las Leyendas muestran una unidad de estilo, temática y recursos, que 
hasta pueden parecer repetitivos e intercambiables en algunos casos. Lo hemos visto en todos los cuadros descritos y analizados, lo que confirma que tal unidad sólo es posible a través de la labor de un artista como Bécquer, que ha sabido elaborar unos recursos ecfrásticos, intermedializándolos --o intertextualizándolos, si usamos la definición más tradicional-- en las Leyendas; lo que añade nuevos matices plásticos al texto y enriquece, en todo caso, la manera en que éste puede ser "visto" y "leído". 


\section{NOTAS AL CAPÍTULO V}

${ }^{1} \mathrm{El}$ romanticismo tuvo un gran desarrollo en la escuela costumbrista sevillana, hasta el punto de ser uno de los grandes hitos del estilo en el concierto nacional. Se relacionan con esta escuela el delicioso costumbrismo de José (m. 1841), Valeriano (m. 1870) y Joaquín Domínguez Bécquer (m. 1879); así como por Manuel Rodríguez Guzmán (m. 1866) y Manuel Cabral A. Bejarano (m. 1891), exponentes todos de esa pintura rebelde a los academicismos puristas en la que, ciertamente y pese a las influencias extranjeras que pueda tener, se contiene la esencia del mejor romanticismo español. El paisajista Manuel Barrón es un fiel representante del romanticismo, con tintes costumbristas, en la escuela sevillana.

2 El tableautin puede traducirse como cuadro de "pequeño formato", de "tamaño reducido", o de "modestas dimensiones". Suele utilizarse comúnmente el término en francés, aunque no están descartadas las anteriores traducciones.

3 "Maese Pérez, el organista" fue publicada en El Contemporáneo, Madrid, los días 27 y 29 de diciembre de 1861.

${ }^{4}$ El origen del neo-popularismo se remonta al Posromanticismo español del siglo XIX, y se manifiesta en el grupo de autores posrománticos inspirados por Heinrich Heine, en particular Gustavo Adolfo Bécquer y Augusto Ferrán. También Rosalía de Castro había asimilado la belleza de los cantares populares tradicionales de su región natal en su primer libro, Cantares gallegos. Ferrán publicó dentro de su libro La soledad (1861) algunos cantares populares de la lírica tradicional que luego imitó él mismo en estilo e inspiración. Creó, pues, con el cercano precedente de Antonio de Trueba y su Libro de los cantares de 1852, y junto a Eulogio Florentino Sanz, también traductor de Heine, y su amigo Gustavo Adolfo Bécquer, una poesía popularista centrada en los cantares y al mismo tiempo deudora del postromántico alemán. La influencia de Heine en Bécquer ha sido estudiada por algunos críticos. En German Romanticism in Gustavo Adolfo Bécquer Short Stories, Henry Charles Turk lleva a cabo un estudio detallado sobre el tema.

${ }^{5}$ La leyenda de "El gnomo" fue publicada en La América, Madrid, el 12 de enero de 1863.

6 "La cueva de la mora" fue publicada en El Contemporáneo, Madrid, el 16 de enero de 1863.

${ }^{7}$ Se suele denominar pictorialista, por extensión, a las pinturas que evocan imágenes nostálgicas con ciertos tintes costumbristas, precisamente por sus orígenes fotográficos, pues surge como tal a finales del siglo XIX y se extiende hasta la Primera guerra mundial. El nombre del movimiento deriva del término inglés picture (imagen, cuadro, pintura, fotografía). 
8 "El beso" (Leyenda toledana) fue publicada en La América, Madrid, el 16 de enero de 1863.

${ }^{9} \mathrm{Al}$ respecto, Bécquer menciona, con este edificio, lo siguiente: "En 1808 las tropas francesas ocuparon a [sic]San Juan de los Reyes, utilizándolo para cuartel y depósito de prisioneros, y cuando les fue preciso abandonarlo, por efecto de sus operaciones, lo saquearon e incendiaron, al par que otros edificios notables de Toledo" Historia de los templos de España 800).

${ }^{10} \mathrm{La}$ animación de las estatuas es común en otras leyendas europeas, y en Bécquer forma parte de la animación de lo inanimado.

11 "La rosa de la pasión” fue publicada en El Contemporáneo, Madrid, el 24 de marzo de 1864.

${ }^{12} \mathrm{El}$ pre-simbolismo define una etapa imprecisa anterior al simbolismo, movimiento literario y pictórico iniciado en Francia y Bélgica hacia 1880 como reacción contra el Naturalismo y el Parnasianismo. 


\section{CONCLUSIONES}

La influencia directa o indirecta de la actividad artístico-familiar y de su entorno, esto es, de los pintores José y Joaquín Domínguez Bécquer, de su hermano Valeriano, así como de los pintores más cercanos, Casado de Alisal y Cabral Bejarano, entre otros, prueban que la pintura no sólo formó parte del diario vivir de Gustavo Adolfo Bécquer, desde muy temprana edad, lo que sin duda estimuló su pasión por el arte, sino que, además, fue decisiva a la hora de decantarse por el estudio de la pintura, durante sus primeros dieciocho años de vida en su Sevilla natal, y hasta después. Además, las enseñanzas recibidas en los talleres sevillanos de Cabral Bejarano, primero, y de Joaquín Domínguez Bécquer --el "tío” Joaquín--, después, prueban que no sólo la influencia ambiental, sino una preparación artística formal dotó a Bécquer del adiestramiento técnico y del conocimiento históricoartístico necesario para acompañar y guiar eficazmente su vocación pictórica, que es la base sobre la cual Bécquer logra estructurar su peculiar discurso literario. Por otra parte, Nombela, sin proponérselo, nos ha dejado la afirmación de que Bécquer, durante su etapa de aprendizaje en los talleres sevillanos, solía dibujar los personajes y escenas de las obras que leía, lo cual prueba que, desde su adolescencia, ya se había iniciado en la práctica de "interpretar" plásticamente los ambientes y personaje literarios, lo que habría de definir su estilo narrativo a la larga. La partida de Bécquer a Madrid, en 1854, no pospone ni disminuye su actividad artística; antes bien ésta se verá estimulada por la febril actividad cultural de la capital, que incluía frecuentes visitas a museos y salas de exposiciones, por un lado, así como por el comienzo de la investigación y preparación, tanto textual como 
gráfica, para su Historia de los templos de España, por otro. La Historia fue, además, un magno proyecto artístico-literario en el que se combinaban equilibradamente sus dos vertientes de interés creativo: la pintura y la literatura. Este ejercicio de integración, a la par que la exhaustiva investigación textual y gráfica que lleva a cabo, terminó por conformar la base de sus leyendas, tanto desde el punto de vista de la trama como de las soluciones plásticas --entre las que se incluyeron (re)creaciones de ambientes, cambios atmosféricos, edificios, ruinas, paisajes, y tipos, entre otros-- que Bécquer insertó con gran acierto en sus Leyendas.

En otro orden de cosas, la actividad artístico-literaria con su hermano Valeriano, con quien desarrolla un interesante trabajo de equipo, arrojó un resultado excepcional. Esto es, Bécquer narraba algunas de las pinturas de Valeriano, y éste ilustraba algunas de las narraciones creadas por su hermano, ya fuese mediante el dibujo, la pintura o el grabado. Este intercambio le hizo a Bécquer mucho más evidentes los resortes de traducción de un medio artístico a otro, como prueban las referencias a este método de trabajo que aparecen en los textos becquerianos. Es evidente, por otro lado, que esta práctica agudizó la expresión pictórica de Bécquer en una dirección específica, como fue la de integrar la pintura en sus textos literarios, mediante descripciones ecfrásticas muy particulares y específicas, como corresponden a un pintor. Por extensión, Bécquer apeló a sus conocimientos de música para "pintar" sus cuadros sonoros, insertándolos de igual manera en las Leyendas.

Los estudios sobre la imagen han puesto de manifiesto una constatación epistemológica: la influencia de la información visual ha aumentado en los últimos 
años, lo que no resta que esto haya sido una verdad desde siempre. En esa dirección, hemos constatado que la capacidad de Bécquer para (re)crear los "objetos visuales", en tanto que objetos ideales o conceptuales, evidencian su forma de percibir o entender el mundo a través de imágenes --ya sean físicas o mentales--, que no sólo motivan acciones, sino que las documentan, como podemos comprobar en las Leyendas. La crítica y la historiografía españolas han permanecido tradicionalmente alejadas de estos territorios del análisis visual de la obra becqueriana, que, por otra parte, forman parte de una continuidad de la historia cultural europea desde los clásicos exponentes de Simónides de Ceos y Quinto Horacio Flaco, sobre todo por el conocido símil de este último: Ut pictura poesis.

Mucho antes de la declaración de Horacio, tanto la pintura como la "poesía" (para nosotros, la palabra escrita o la literatura) aparecían relacionadas mediante el término de mímesis. Aristóteles, que se anticipa a muchas referencias sobre la “imitación" de unas artes a otras, deja consignada en su Poética algunas reflexiones sobre la "representación", que la hermana, de cierta manera, al concepto de écfrasis, puesto que para él todas las artes son el resultado de la "imitación", es decir, de la mímesis. Dado que la pintura --y las artes plásticas en general-- son formas de la mímesis que se pueden relacionar con otras formas de igual naturaleza mimética (la palabra escrita, por ejemplo), como ha sido probado desde antiguo, entonces, la comparación implícita que hace Bécquer de la literatura con la pintura es válida desde este punto de vista. Así tenemos que Bécquer, al insertar el objeto visual de forma intertextual o intermedial en las Leyendas --lo cual hace valiéndose de construcciones verbales que se apoyan en el acto de "imitar"--, nos lleva a concluir 
que la mímesis está implícita en los recursos ecfrásticos elaborados por Bécquer, por su propia naturaleza de "imitar".

Por otro lado, la inserción de esos recursos plásticos intertextualizados --las llamadas intermedialidades-- contribuye de manera significativa a estimular la recepción literaria y a aumentar la comprensión textual por parte del lector, lo que hace de estos recursos el medio indiscutible para potenciar la riqueza léxica del texto literario. En este sentido, Bécquer se vale de una "traducción" a signos verbales de una representación visual, que puede ser real o imaginada. Además, como hemos comprobado, en esta traducción concurre la mirada del Bécquerartista, que matiza o (re)interpreta el objeto visual desde un punto de vista artístico. Sin embargo, la elaboración y plasmación literaria del objeto visual la lleva a cabo el Bécquer-narrador. Por lo tanto, estamos ante un caso de un pintor-narrador en cuya obra resulta imposible dividir en planos aislados sus dos actividades creativas; esto es, la creación literaria y la pictórico-musical.

Bécquer se sirve de referentes pictóricos, escultóricos, arquitectónicos, e incluso paisajísticos, entre otros, que nos remiten a las obras de artistas como Lorrain, Murillo, Rembrandt (mencionados en becquerianos) o a pintores barrocos y románticos, que pueden ser identificables, al menos en su estilo, en muchas de las Leyendas. Estos referentes, sin embargo, aparecen "reinterpretados" mediante écfrasis referenciales genéricas o écfrasis literarias, de acuerdo con algunas de las definiciones estudiadas, por cuanto traducen, generalmente, un cuadro inmaterial o inexistente. Es decir, no se producen en las Leyendas--a pesar de las referencias a los artistas de su preferencia en obras como Desde mi celda u otras--, alusiones o 
traducciones artísticas de obras específicas. Sus descripciones, "nos remiten a ciertas obras", pero sólo nos remiten. En el acervo cultural y en las experiencias del lector-espectador se hallan los referentes materiales. Por lo tanto, podemos afirmar como resultado de nuestro análisis, que ésta es una peculiaridad de las Leyendas. Debo destacar que, basado en esto, habrá tantos cuadros imaginados como lecturas posibles de estos relatos por parte de los lectores-espectadores.

Creemos, por otro lado, que la afirmación de no poder describir determinadas escenas, como insiste una y otra vez durante la lectura de estos relatos, es uno de los recursos ecfrásticos más eficaces, porque, de cierta forma, desplaza temporalmente al texto --pero sólo de forma temporal-- para dar paso a la descripción de imágenes que pertenecen al campo de lo icónico. Al presentar el "cuadro descriptivo ecfrástico" en lugar del texto, Bécquer logra que nos concentremos en "ver" la descripción que, en última instancia, lleva a cabo por medio de la palabra; esa palabra que para él es tan inútil e insuficiente, pero que, en nuestra opinión, no hace más que otorgarle una capacidad descriptiva excepcional. En realidad, Bécquer no deja nunca de escribir, pero nos convence, en aquellos momentos en que cree que la imagen es más útil que la palabra, de que "ver" es un mejor recurso, más completo en su capacidad de describir. Por eso, se ha insistido tanto en los conceptos de prosa plástica o poesía narrada, aunque resulta difícil anteponer un concepto al otro. De ello también se desprende el hecho de que Bécquer creyó --y probó-- que una narración, en la que las imágenes cobraban un protagonismo destacado, era mucho más efectiva y mucho más artística, como correspondía a los temas y ambientes de las Leyendas. También queda comprobada 
la capacidad de Bécquer para distribuir las imágenes en el cuadro --es decir, componer-- siguiendo una suerte de trazado compositivo como lo hace el artista ante un soporte cualquiera, sea papel o tela. Hemos visto, además, cómo diseña el escenario, así como a los personajes que se mueven en él, siguiendo reglas de equilibro en la composición, propias de un pintor. Además, ha quedado probada la multiplicidad de planos --o niveles de distancia con relación al primer plano-- que utiliza al pintar sus escenarios o fondos pictóricos, y mover a los actores, así como su particular estilo de presentar dualidades, que pueden ser vistas y leídas desde diferentes perspectivas.

Esta tesis abre el camino para ulteriores estudios en el campo de los recursos ecfrásticos. Su importancia reside en haber ahondado en un aspecto de la obra becqueriana que no ha sido suficientemente estudiado, aunque mucho se ha escrito de su prosa-poética plástica y sensorial. Este trabajo no agota las posibilidades de abordaje a la obra de Bécquer, siguiendo esta línea de investigación, que podría extenderse a otras narraciones o a su poesía con la que comparte idénticos recursos plásticos. Por otro lado, su influencia es innegable. No hay duda de que la huella pictórica de Bécquer podemos hallarla en escritores de la Generación del 98, en los escritores modernistas, e incluso en escritores de la Generación de 1927; pienso en escritores con inquietudes pictóricas como Lorca o Alberti, por ejemplo. La singularidad --lo más original, si se quiere-- de la prosa de Bécquer debemos encontrarla en su capacidad para trasladar unas imágenes pictóricas al texto literario mediante el recurso de la écfrasis. En este espacio de convergencia de la imagen y la palabra es donde se halla el gran aporte de la prosa becqueriana. 


\section{OBRAS CITADAS}

Abrams, M. H. The Mirror and the Lamp. New York: Oxford University Press, 1953. Impreso.

Alberti, Leon Battista. On Painting (De Pictura): A New Translation and Critical Edition. Trad. Rocco Sinisgalli. Londres: Penguin Books, 2013. Impreso.

Amador de los Ríos, José. Sevilla pintoresca. Sevilla: F. Álvarez y Cía., 1844. Impreso.

Antigüedad, María Dolores y Sagrario Aznar. El siglo XIX. El cauce de la memoria. Madrid: Ediciones Istmo, 1998. Impreso.

Aristóteles. Poética. Trad. Salvador Mas. Madrid: Biblioteca Nueva, 2002. Impreso.

Argullol, Rafael. La atracción del abismo. Un itinerario por el paisaje romántico. Barcelona: Ediciones Destino. Colección Áncora y Delfín, 2000. Impreso.

Baquero Goyanes, Mariano. El cuento español: del Romanticismo al Realismo. Alicante: Biblioteca Virtual Miguel de Cervantes, 2012. Impreso.

Barthes, Roland. S/Z. Trad. Nicolás Rosa. Madrid: Siglo XXI Editores, 1980. Impreso.

Battistessa, Ángel J. "En torno a Bécquer". Ed. Honorée Compiler. Poetas y prosistas españoles. Buenos Aires: Institución Cultural Española, 1943. 89-114. Impreso.

Baudelaire, Charles. Écrits sur l'art. 2 Vols. París: Livre de Poche, 1971. Impreso.

Bécquer, Gustavo Adolfo. Leyendas. Madrid: Ediciones Cátedra. Letras Hispánicas, 2000. Impreso.

---. Narraciones. Madrid: Ediciones Cátedra. Letras Hispánicas, 2007. Impreso.

---. Ed. Joan Estruch Tobella. Obras Completas. Madrid: Ediciones Cátedra, Bibliotheka AVREA, 2004. Impreso.

Benítez, Rubén. Bécquer tradicionalista. Madrid: Editorial Gredos, 1971. Impreso.

Berenguer Carisomo, Arturo. La prosa de Bécquer. Buenos Aires: Librería Hachette, 1947. Impreso. 
Bergman, Emilie L. Art Inscribed: Essay on Ekphrasis in Spanish Golden Age Poetry. Cambridge, Massachusetts: Harvard University Press, 1979. Impreso.

Beuchot, Maurice. Semiótica. México D.F.: Fondo de Cultura Económica, 2004. Impreso.

Brown, Rica. Gustavo Adolfo Bécquer, en dos tiempos. Barcelona: Editorial Aedos, 1963. Impreso.

Bynum, B. Brant. The Romantic Imagination in the Works of Gustavo Adolfo Bécquer. Chapel Hill: University of North Carolina at Chapell Hill, 1993. Impreso.

Carpintero, Heliodoro. Bécquer de par en par. Madrid: Ínsula, 1957. Impreso.

Caws, Mary Ann. The Art of Interference: Stressed Readings in Verbal and Visual Texts. Princeton, N.J.: Princeton University Press, 1989. Impreso.

Cejador y Frauca, Julio. Historia de la lengua y la literatura castellana. T. VI. Madrid: Tipografía de la revista de archivos, bibliotecas y museos, 1917. Impreso.

Cernuda, Luis. Ed. José María Capote. Antología poética. Madrid: Ediciones Cátedra, 1988. Impreso.

Chaffee-Sorace, Diane. "Visual Art and Literature: The Role of Time and Space in Ekphrastic Creation". Revista Canadiense de Estudios Hispánicos 8.3 (1984): 308-20. Impreso.

Chateaubriand, François René de. Génie du Christianisme. París: Livre de Poche, 1993. Impreso.

Cirisi Narváez, Juan Ramón. La pintura costumbrista en el Museo de Cádiz. Cádiz: Consejería de Cultura de Andalucía, 2007. Impreso.

Clüver, Claus. "On Intersemiotic Transposition". Poetics Today 10.1 (1989): 5590. Impreso.

Corbacho Cortés, Carolina. Literatura y Arte: El tópico "Ut Pictura Poesis". Cáceres: Universidad de Extremadura, 1998. Impreso.

D’Angelo, Paolo. La estética del Romanticismo. Trad. Juan Díaz de Atauri. Madrid: Visor. Léxico de estética, 1999. Impreso. 
D’Asprer, Núria. "Visualidad y escritura". Saltana. Revista electrónica de literatura y traducción 6270 (1971): 1.14 nov. 2014. Web. www.saltana.org.

Davidson, Michael. "Ekphrasis and the Postmodern Painter Poem". The Journal of Aesthetics and Art Criticism 42.1 (1983): 69-79. Impreso.

Da Vinci, Leonardo. Ed. Ángel González García. Tratado de la pintura. Trad. Diego A. Rejón de Silva. Madrid: Edimat Libros, 2005. Impreso.

De la Banda y Vargas, Antonio. "Sevilla en la obra de Gustavo Adolfo Bécquer". Archivo Hispalense. Revista histórica, literaria y artística 54.165 (1971): 131-36. Impreso.

De Armas, Frederick A. "La écfrasis y los efectos del arte en el teatro de Lope de Vega". EHumanista 24 (2013): 60-79. Impreso.

De Saussure, Ferdinand. Mémoire sus le système primitif des voyelles dans les langues indo-européennes. París: Adamant, 2003. Impreso.

Díaz, José Pedro. Gustavo Adolfo Bécquer vida y poesía. Madrid: Editorial Gredos, 1958. Impreso.

Díaz Plaja, Guillermo. Introducción al estudio del Romanticismo español. Madrid: Espasa Calpe, 1967. Impreso.

Dictionary of Art. Ed. Jane Turner. New York: Grove, 1996. Impreso.

Diderot, Denis. Salons. OEuvres de Denis Diderot. 10 Vols. París: Elibron Classics, 2001. Impreso.

Du Bos, Jean-Baptiste. Réflexions Critiques sur la Poésie et sur la Peinture. París: Chez Jean Mariette, 1719.

Eco, Umberto. Mouse or Rat. Londres: Phoenix Literature, 2004. Impreso.

Fernández Lacomba, Juan. "El paisaje andaluz de la mirada ilustrada al boom turístico". Ed. Junta de Andalucía. Los paisajes andaluces. Hitos y miradas en los siglos XIX y XX. Sevilla: Junta de Andalucía, 2007. 17-144. Impreso.

Fernández Montesinos, José. Costumbrismo y novela. Madrid: Editorial Castalia, 1983. Impreso.

Filóstrato, el Viejo, el Joven Filóstrato y Calístrato. Imágenes y descripciones. Trad. L. A. de Cuenca y M. A. Elvia. Madrid: Editorial Siruels, 1993. Impreso. 
Flitter, Derek. Teoría y crítica del Romanticismo español. Trad. Fernández Salgado. Cambridge: Cambridge University Press, 1995. Impreso.

Ford, Richard. Ed. Ian Robertson. Gatherings from Spain. Londres: Pallas Athene, 2000. Impreso.

Gamallo Fierros, Dionisio. Del olvido en el ángulo oscuro. Madrid: Valera, 1948. Impreso.

García Felguera, María de los Ángeles. "Los extranjeros y el nacimiento de la pintura costumbrista andaluza”. Ed. Juan A. López Manzanares. Pintura Andaluza. Madrid: Ediciones El Viso, 2004. 11-26. Impreso.

García-Viñó, Manuel. Mundo y transmundo de las leyendas de Bécquer. Madrid: Editorial Gredos, 1970. Impreso.

Gautier, Théophile. Voyage en Espagne. París: GF Flammarion, 1981. Impreso.

---. L’Inde. París: GF Flammarion, 1980. Impreso.

Geisdorfer Feal, Rosemary y Carlos Feal. Painting on the Page. New York: State of New York University Press, 1995. Impreso.

Genette, Gérard. Palimpsestes. La litterature au second degré. París: Éditions du Seuil, 1982. Impreso.

Gonda, Jan. Le religione dell India. Veda e Antico Induismo. Milán: Jaca Book, 1981. Impreso.

González Troyano, Alberto. "Richard Ford: Entre los últimos románticos y los primeros hispanistas". Ed. Francisco J. Rodríguez. La Sevilla de Richard Ford. Sevilla: Fundación El Monte, 2007. 17-26. Impreso.

---. Barroco y Romanticismo (Dos ensayos). Murcia: Editorial de la Universidad de Murcia, 1950. Impreso.

Guerrero Lovillo, José. "Los pintores románticos sevillanos". Archivo Hispalense 11.2 (1949): 36-38. Impreso.

Gulsoy, Joseph. "La fuente común de los ojos verdes y el rayo de luna de Bécquer". Bulletin of Hispanic Studies 44.2 (1967): 96-106. Impreso.

Hadjinicolaou, Nikos. La producción artística frente a sus significados. Trad. Uxoa Doyhamboure y Oscar Barahona. México: Siglo XXI Editores, 1991. Impreso. 
Hagstrum, Jean H. The Sister Arts. The Tradition of Literary Pictorialism. Chicago: University of Chicago Press, 1958. Impreso.

Hauser, Arnold. Introducción a la historia del arte. La Habana: Instituto del libro, 1969. Impreso.

Heffernan, James A. W. Museum of Worlds. Chicago: University of Chicago Press, 1993. Impreso.

Henares Cuéllar, I. L. y J. A. Calatrava. "El historicismo en la crítica de arte del Romanticismo español". Revista del Departament des Ciènces Historiques i Teoria de les Arts 19.1 (1979): 309-22. Impreso.

Henckmann, Wolfhart y Konrad Lotter. Diccionario de estética. Trad. Daniel Gamper y Begoña Sáez. Barcelona: Crítica, 1998. Impreso.

Hernando, Javier. El pensamiento romántico y el arte en España. Madrid: Ediciones Cátedra, 1995. Impreso.

Hollander, John. "The Poetic of Ekphrasis". Word and Image: A Journal of verbal/Visual Enquiry 4.1 (1988): 209-19. Impreso.

Homero. La Iliada. Trad. Luis Segala y Estalella. México, D.F.: Porrúa, 1993. Impreso.

Horacio, Quinto Flaco. Epístola a los Pisones (Epistolae ad Pisones). Trad. Helena Valenti. Barcelona: Bosch, 1961. Impreso.

Jakobson, Roman. K. Pomorska y S. Rudy. Language in Literature. Cambridge, Mass.: Harvard University Press, 1987. Impreso.

James, Carol P. "Duchamp's Early Readymades. The Erasure of Boundaries Between Literature and the Other Arts". Perspective on Contemporary Literature. Louisville: Kentucky University Press, 1987. 24-32. Impreso.

Jennings Oates, Whitney. The Influence of Simonides of Ceos Upon Horace. New York: Haskell House Publishers, 1971. Impreso.

Jiménez Blanco, María Dolores. "El nacimiento de la arqueología. El pasado desmitificado". Ed. Narcí Serra i Serra. El esplendor de la ruina. Barcelona: Fundación Caixa de Cataluña, 2005. 87-131. Impreso.

King, Edmond L. Gustavo Adolfo Bécquer: From Painter to Poet. Mexico D. F.: Editorial Porrúa, 1953. Impreso. 
Krieger, Murray. Poetic and Presence Illusion Essays in Critical History and Theory. Baltimore: The John Hopkins University Press, 1979. Impreso.

---. "El problema de la écfrasis: imágenes y palabras, espacio y tiempo, y la obra literaria" Ed. Antonio Monegal. Pintura y literatura. Madrid: Arco, 2000. 139-160. Impreso.

Kristeva, Julia. Le language, cet inconnu. París: Éditions du Seuil, 1981. Impreso.

Kurman, George. "Ekphrasis in Epic Poetry". Comparative Literature 26 (1974): 1-13. Impreso.

Lee Rensseter, W. Ut Pictura Poesis. La teoría humanística de la pintura. Trad. C. Luca de Tena. Madrid: Ediciones Cátedra, 1982. Impreso.

Lejeune, Philippe. On Autobiography. Theory and History of Literature. Minneapolis-Saint Paul: University of Minnesota Press, 1989. Impreso.

Lizarazo, Diego. Iconos, figuraciones, sueños. México, D.F.: Siglo XXI, 2009. Impreso.

---. Coord. Semántica de las imágenes. Figuración, fantasía e iconicidad. México, D.F.: Siglo XXI, 2007. Impreso.

---. Coord. Interpretaciones icónicas. Estética de las imágenes. México, D.F.: Siglo XXI, 2007. Impreso.

Llewelyn, John. "Representation in Language". Ed. Ananta Ch. Sukla. Art and representation. Londres: Praeger, 2001. 29-58. Impreso.

Llorens, Vicente. El Romanticismo español. Madrid: Editorial Castalia, 1979. Impreso.

Longinus, Dionysius Cassius. On the Sublime. Whitefish, Montana: Kessinger Publishing, LLC, 2010. Impreso.

Lotman, Yuri M. Extructura del Texto Artístico. Trad. Victoriano Imbert. Madrid: Ediciones Akal, 2011. Impreso.

Lozano, J; Peña-Marín, C. y Abril, G. Análisis del discurso. Hacia una semiótica de la interacción textual. Madrid: Ediciones Cátedra, 1982. Impreso.

McLuhan, Marshall, and Harley Parker. Through the vanishing Point: Space in Poetry and Painting. New York: Harper and Row, 1968. Impreso. 
Mancini, Guido. "Popolarismo e Società in Bécquer" Revista de filología española 1.4(1969): 53-66. Impreso.

Marchese, Angelo y Joaquín Forradellas. Diccionario de retórica, crítica y terminología literaria. Barcelona: Ariel, 1986. Impreso.

Martínez Fernández, José Enrique. La intertextualidad literaria. Madrid: Ediciones Cátedra, 2001. Impreso.

Mitchell, W. J. T. Iconology, Image, Text, Ideology. Chicago: The University of Chicago Press, 1986. Impreso.

---. "Más allá de la comparación: Imagen, texto y método". Ed. Antonio Monegal.

Pintura y literatura. Trad. Ana Romero. Madrid: Arco, 2007. 223-54. Impreso.

Monegal, Antonio. "Notas". Pintura y Literatura. Madrid: Arco, 2000. 9-21. Impreso.

Montesinos, Rafael. Bécquer, biografía e imagen. Barcelona: Editorial RM, 1977. Impreso.

Moore, Hyatt. The Alphabet Makers. Huntington Beach, CA: The Summer Institute of Linguistics, 1991. Impreso.

Navas Ruiz, Ricardo. El romanticismo español. Madrid: Cátedra, 1990. Impreso.

Nieto Taberné, Tomás. Arquitectura: historicismo. MCNArte.com. Web 12 dic. 2014. www.mcnarte.com/app-arte/do/show.

Nombela, Julio. Impresiones y recuerdos. Madrid: Ediciones Gener, 1976. Impreso.

Oxford English Dictionary. Ed. J. A. H. Murray. Londres: Oxford University Press, 2013. Impreso.

Panebianco, Candido. L'esotismo indiano di Gustavo Adolfo Bécquer. Roma: Bulzoni, 1988. Impreso.

Pageard, Robert. Bécquer leyenda y realidad. Rev. María Dolores Cabra. Madrid: Espasa-Calpe, 1990. Impreso.

Pérez Villaamil, Genaro. Ed. J. de J. Editores. España artística y monumental. Vistas y descripción de los sitios y monumentos más notables de España (Ed. facsimilar). Madrid: Kalamo Libros, 2010. Impreso. 
Persin, Margaret H. Getting the Picture. The Ekphrastic Principle in TwentiethCentury Spanish Poetry. Londres: Associate University Presses: 1997. Impreso.

---. "The Ekphrastic Principle in the Poetry of Manuel Machado". Hispania 72.4 (1989): 219- 227. Impreso.

Pimentel, Luz Aurora. El espacio en la ficción. México, D.F.: Siglo XXI Editores, 2001. Impreso.

---. "Configuraciones descriptivas: articulaciones simbólicas e ideológicas de la narrativa de ficción". Poligrafías 1 (1996): 105-120.

Platón. República. Libro X. Trad. María Divenosa y Claudia Mársico. Buenos Aires: Losada, 2005. Impreso.

Plett, Heinrich F. "La teoría de la intertextualidad en Alemania". Ed. y trad. Desiderio Navarro. Criterios. La Habana, 1993. 50-84. Impreso.

Plutarch. Ed. y trad. Franck Cole Babitt. De Gloria Atheniensium. Cambridge, MA: Harvard University Press, 1936. Impreso.

Pozuelo Yvancos, José María. Teoría del lenguaje literario. Madrid: Ediciones Cátedra. Crítica y estudios literarios, 1994. Impreso.

Praz, Mario. Mnemosyne The Parallel Between Literature and the Visual Arts. Washington, D.C.: Princeton University Press, 1970. Impreso.

R. A. E. Diccionario de la Real Academia Española. Madrid: Editorial Espasa Calpe, 1992. Impreso.

Regueiro Salgado, Begoña. "Una nueva forma de orientalismo romántico: presencia y valores de lo oriental en la obra de Gustavo Adolfo Bécquer". Bulletin of Spanish Studies 90.2 (2013): 177-194. Impreso.

Reina Gómez, Antonio. El paisaje en la pintura sevillana del siglo XIX. Sevilla: Diputación deSevilla, 2010. Impreso.

Rifaterre, Michael. "La ilusión de écfrasis". Ed. Antonio Monegal. Pintura y Literatura. Trad. Carlos Besa. Madrid: Arco, 2007. 161-183. Impreso.

Robertson, Ian. "Richard Ford y las cosas de España". Ed. Francisco J. Rodríguez . La Sevilla de Richard Ford. Sevilla: Fundación El Monte, 2007. 27-56. Impreso. 
Robillard, Valerie. "En busca de la écfrasis (Un acercamiento intertextual)". Eds. Susana González e Irene Artigas. Entre artes; entre actos: écfrasis e intermedialidad. México, D.F.: UNAM, 2011. 39-49. Impreso.

Rodríguez Barberán, Francisco J. "La ciudad como templo: Arquitectura religiosa". Ed. Francisco Rodríguez. La Sevilla de Richard Ford. Sevilla: Fundación El Monte, 2007. 219-30. Impreso.

Rubio Jiménez, Antonio. Pintura y literatura en Gustavo Adolfo Bécquer. Sevilla: Fundación José Manuel Lara, 2006. Impreso.

Russomanno, Stefano. Los escritores y la música. Trad. Stefano Russomanno. Roma: Instituto Dante Alighieri, 2009. Impreso.

Said, Edward W. Orientalismo. Trad. María Luisa Fuentes. Barcelona: Debolsillo, 2002. Impreso.

Sarduy, Severo. La Simulación. Caracas: Monte Ávila Editores, 1982. Impreso.

Schneck, Ernst-Peter. "Pictorial Desires and textual Anxieties: Modes of Ekphrastic Discourse in Nineteenth-Century American Cultures". Word and Images. A journal of Verbal and Visual Enquiry 15.1 (1999): 54-62. Impreso.

Schneider, Franz. Gustavo Adolfo Becquers Leben und Shaffen. Leipzig: Universität Leipzig, 1914. Impreso.

Schweizer, Niklaus. The Ut Pictura Poesis Controversy in Eighteenth Century England and Germany. Frankfurt: Herbert Land, 1972. Impreso.

Sébillot, Paul. Le folklore de France. Paris: Imago Editeurs, 1992. Impreso.

Segre, Cesare. Principios de análisis del texto literario. Trad. María Pardo de Santayana. Barcelona: Crítica, 1985. Impreso.

Silver, Philip W. Ruina y restitución: Reinterpretación del Romanticimo en España. Trad. José Luis Gil Aristu. Madrid: Ediciones Cátedra, 1996. Impreso.

Smith, Mack. Literary Realism and the Ekphrastic Tradition. Philadelphia: The Pennsylvania State University Press, 1995. Impreso.

Souriau, Etienne. "Time in the Plastic Arts". Journal of Aesthetics and Art Criticism 7.4 (1949): 294-307. Impreso. 
Spitzer, Leo. "The Ode on a Grecian Urn or Content vs. Metagrammar". Comparative Literature 7.3 (1955): 203-225. Impreso.

Steiner, Wendy. Pictures of Romance. Form Against Context in Painting and Literature. Chicago: The University of Chicago Press, 1988. Impreso.

--- "La analogía entre la pintura y la literatura". Ed. Antonio Monegal. Pintura y literatura. Trad. Ana Romero. Madrid: Arco, 2000. 9-24. Impreso.

Talens, Jenaro et al. Elementos para una semiótica del texto artístico. Madrid: Cátedra, 1999. Impreso.

Tangherlini, Timothy R. "The Beggar, the Minister, the Farmer, his Wife and the Teacher" Ed. Terry Gunnell. Legends and Landscape. Rikjavik: University of Iceland Press, 2009. 171-95. Impreso.

Torres González, Begoña. "Introducción”. Ed. Juan Navarro Hernanz. Amor y muerte en el Romanticismo. Barcelona: Ámbit Servicios Editoriales, 2001. 13-78. Impreso.

Vidal Oliveras, Jaume. "El silencio de las ruinas". El Cultural 14 jul. 2005. 1-3. Impreso.

Villafranca Jiménez, María del Mar. "Los museos andaluces: pasado, presente y perspectivas de futuro". Revista de museología 13. (1998): 27-37. Impreso.

Villanueva, Darío. Introducción. Desde mi celda. Madrid: Castalia, 1985. Impreso.

Ward, Patricia A. "Encoding in the Texts of Literary Movements: Late European Romanticism". Comparative Literature Studies 18.2 (1981): 296-305. Impreso.

Wellek, Rene. "The Parallelism between Literature and the Arts". English Institute Annual (1941): 29-63. Impreso.

Wellek, Rene and Austin Warren. Teoría literaria. Madrid: Editorial Gredos, 1974. Impreso.

Wimsatt, William. K., Jr. "Is a General Theory of the Arts of Any Practical Value in the Study of Literature? I. The Domain of Criticism". The Journal of Aesthetics and Art Criticism 8. 4 (1950): 221-28. Impreso. 
VITA

JOSÉ LUIS RODRÍGUEZ

Born, Habana, Cuba

2015

Ph.D. Spanish

Florida International University

2002

M.A. Spanish

Florida International University

1978

B.A. French Language and Literature University of Habana

1974

B.A. Art History University of Habana

2014-Present

C. \& C. Services

1989-1998

Tutoring French and Spanish

1998-2014

Miami-Dade Public Schools System

Teacher of Spanish and French (High School)

2006-2014

Department Chair Modern Languages

Language Program Coordinator

Coral Park S. H. S.

1997-1998

Teaching Assistant

Florida International University

1978-1989

Editor Assistant/Art Director

Americas Publishing House 